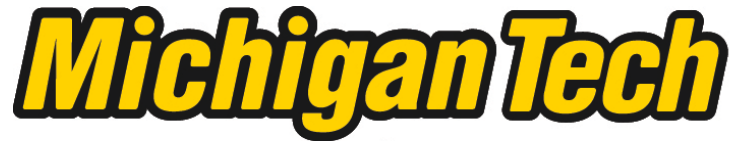 \\ Michigan Technological University Create the Future Digital Commons @ Michigan Tech
}

Dissertations, Master's Theses and Master's Reports - Open

Dissertations, Master's Theses and Master's

Reports

2005

\section{Through the back door : Melungeon literacies and 21st century technologies}

Katherine G. Vande Brake

Michigan Technological University

Follow this and additional works at: https://digitalcommons.mtu.edu/etds

Part of the Rhetoric and Composition Commons

Copyright 2005 Katherine G. Vande Brake

\section{Recommended Citation}

Vande Brake, Katherine G., "Through the back door : Melungeon literacies and 21st century technologies", Dissertation, Michigan Technological University, 2005.

https://doi.org/10.37099/mtu.dc.etds/96

Follow this and additional works at: https://digitalcommons.mtu.edu/etds

Part of the Rhetoric and Composition Commons 
THROUGH THE BACK DOOR:

MELUNGEON LITERACIES

AND $21^{\text {ST }}$ CENTURY TECHNOLOGIES

By

KATHERINE G. VANDE BRAKE

\section{A DISSERTATION}

Submitted in partial fulfillment of the requirements

for the degree of

DOCTOR OF PHILOSOPHY

(Rhetoric and Technical Communication)

MICHIGAN TECHNOLOGICAL UNIVERSITY 


\begin{abstract}
The Melungeons, a minority recognized in Southern Appalachia where they settled in the early 1800s, have mixed heritage-European, Mediterranean, Native American, and Sub-Saharan African. Their dark skin and distinctive features have marked them and been the cause of racial persecution both by custom and by law in Appalachia for two centuries. Their marginalization has led to an insider mentality, which I call a "literacy" of Melungeon-ness that affects every facet of their lives.

Just a century ago, while specialized practices such as farming, preserving food, hunting, gathering, and distilling insured survival in the unforgiving mountain environment, few Melungeons could read or write. Required to pay property taxes and render military service, they were denied education, suffrage, and other legal rights. In the late 1890s visionary Melungeon leader Batey Collins invited Presbyterian home missionaries to settle in one Tennessee Melungeon community where they established a church and built a school of unparalleled excellence. Educator-ministers Mary Rankin and Chester Leonard creatively reified the theories of Dewey, Montessori, and Rauschenbusch, but, despite their efforts, school literacy did not neutralize difference.

Now, taking reading and writing for granted, Melungeons are exploring their identity by creating websites and participating in listserv discussions. These online expressions, which provide texts for rhetorical, semiotic, and socio-linguistic analysis, illustrate not solidarity but fragmentation on issues of origins and legitimacy. Armed with literacies of difference stemming from both nature and nurture, Melungeons are using literacy practices to embrace the difference they cannot escape.
\end{abstract}




\section{Acknowledgments}

When I look back over the last six years, I realize it has been the very best time of my life and that going for the Ph.D. was my very best decision. There are many thanks due. First I must thank King College, the institution where I have taught for 27 years. The Dean of Faculty and the President applauded my decision to return to graduate school, funded a one-semester sabbatical at the outset, and granted me two years' leave of absence to complete my coursework. When I returned after my comps, they looked the other way when I said no to almost everything except teaching my classes, so I could finish my research and dissertation. So to King College, thank you.

I am also grateful to the Appalachian College Association for two years of funding that helped pay for my time in residence at Michigan Tech. There is a group of important people who were at Michigan Tech and are now scattered abroad. Thanks go to Cindy Selfe for believing in me from the beginning and encouraging me to apply to the grad program, to Anne Wysocki who saw my dissertation topic long before I did and pointed it out to me, to Marilyn Cooper for inspiration and direction. Thanks, too, to my committee: Diana George (Chair), Bob Johnson, Kedmon Hungwe, and Vicky Bergvall. You all encouraged me, met with me, and made so many helpful suggestions. Diana said from the outset, "Think book, Katie." So, I did.

To my colleagues Charlene Kiser at Milligan, Kim Holloway and Craig McDonald at King goes unmitigated gratitude. Your encouragement was so important. Then, too, there are the King College IT staffers, Don Walters and Joel Robertson, who rescued me the day one chapter suddenly multiplied to 3000 pages in a matter of 60 
seconds. I couldn't have done it without them. Crystal Davidson in the library helped me procure countless books and articles on inter-library loan.

My personal support team was both tolerant and sustaining. Friends Allen Radtke, Nancy Cook, Kathy and John Viskant, Kate Tingley, and Nancy White cheered me on day by day. Sandra Grubbs prayed me through the long months of research, the tedious days of writing, and the heartbreak of losing both parents during the writing project. Finally, I must thank my family, children and grandchildren: Peter and Susan and their children Olivia and Annake; Tim and Julie and their children Sarah, Emma, and Timothy; Matthew and Shane and their son Miles. You allowed me to be preoccupied and inaccessible; you let me talk with you about the Melungeons and about my analysis of their situation, and you told me you were proud of me.

To each one, thank you. 


\section{Table of Contents}

Introduction

$\begin{array}{lll}\text { Chapter } 1 \text { Definition and Speculation: } & 2\end{array}$

What "Melungeon" Means and Where They Originated

Chapter 2 The Powerful Ties That Bind: 35

A Community Created by Shared Experience

Chapter 3 One Way to Tackle Barriers: Get Help 86

Chapter 4 Chester Leonard: Going Beyond the Basic Blueprint 130

$\begin{array}{lll}\text { Chapter } 5 \text { Assessing the Vardy Experiment: } & 188\end{array}$

Intervention in Culture and Sponsorship of Literacy

Chapter 6 A World Depicted and Displayed: Melungeon Websites 216

Chapter 7 Two Contemporary Melungeon Rhetors: 285

Chapter $8 \quad$ It Was A Wired Neighborhood: 306

One Discussion Thread on Melungeon-L

Conclusion Conclusion: A View from Outside 344

$\begin{array}{ll}\text { Bibliography } & 348\end{array}$ 


\section{Introduction}

\section{X 2: TWO TELLING INTERVIEWS, TWO RESEARCH PROBLEMS}

Six years ago I wrote a book about Melungeon characters in Appalachian fiction. I perceived my audience for that book to be Melungeon people who, if I were to believe postings to the Melungeon email list, found portrayals of Melungeons in fiction to range from demeaning to slanderous. I knew no one personally who claimed to be Melungeon. At the Sneedville Fall Festival in October of 1999, I met very briefly several list contributors and three members of the Vardy Community Historical Society. Nonetheless, despite my ignorance, I felt certain that by clear analysis and cogent prose, I could convince my chosen audience that the Appalachian authors meant no ill will toward these people and that being represented in fiction was more of an honor than an insult.

I was wrong. I may never convince them, and that's no longer my aim.

I did not then understand the power of long years of prejudice and discrimination. For people with Melungeon blood, their history has shaped their perceptions of the society around them and their expectations for the future. Since I wrote that book in the summer of 2000, I have continued my quest not only to know but also to understand. I have read countless books and articles; I spoke as an "expert” about Melungeon characters in fiction at both Fourth and Fifth Union, Melungeon Gatherings in Kingsport, Tennessee, in 2002 and 2004; and I have met and talked with many people inside the 
Melungeon community. By far, the most mind-altering part of my research has been getting to know Melungeon people. This has happened in a variety of ways. Some I "met" first through their postings to Melungeon-L. Others had written books, which I read before I met them face-to-face. Still others were, initially for me, voices from Wayne Winkler's PBS documentary or from their presentations at the Unions. Putting faces with the familiar voices widened my circle. And, finally, there are the men and women I have interviewed. They have probably been the most influential. Their stories, insights, and answers to my questions sent me back to the books, articles, and websites with a new perspective and hints about what to look for in those texts. They have lived the "legend" and are willing to talk about it in a focused way. Two incidents during the process of my interviews stand out and were the springboard for a refocused perspective.

The first incident occurred at the home of one of my informants. We were sitting at her kitchen table poring over Vardy Presbyterian Church records, letters, her scrapbook, and family photographs. Pointing to old pictures of both her mother and grandmother when they were at boarding schools in North Carolina, she was telling me that both women left their home in Vardy, the valley community between Newman's Ridge and Powell Mountain along Blackwater Creek near Sneedville, Tennessee, to get high school and college education. Suddenly she paused: "You know they never could have gone to school in Sneedville; they wouldn't have been allowed."

They were excluded, not wanted, not welcomed - two generations of women from a landowning Tennessee family. The grandmother would have gone away to school around the turn of the twentieth century; the mother in the 1920s. Both of them attended one-room schools in Vardy: the grandmother at the log cabin meeting house/school built 
just after the Civil War and her daughter at the one-room primary school built by the Presbyterian missionaries in 1902.

The second incident happened when one of my informants was taking me on a drive up the Vardy Valley and over Newman's Ridge to the main road that runs from Sneedville to Kyle's Ford. This man attended the Vardy Community School in the 1960s; by then it was still staffed by Presbyterian missionaries but was administered and funded by Hancock County. As we drove up the switchbacks of the gravel road, he pointed out sites of homes of Melungeon people whose names I recognized. One is a new house that belongs to Seven Gibson, a Melungeon descendant who pastors the thriving Elm Springs Baptist Church just southwest of where the Vardy Road turns off of the main road from Sneedville to Mulberry Gap. For the most part, the old houses and log cabins are long gone; trees and underbrush have taken over the clearings. There is little evidence that people ever lived there. As we crested the ridge top and started down the other side, he gestured to a thriving farm definitely still inhabited. "We never came over this far," he said, “and I bet you can guess why since you've done so much research." He glanced over at me, waiting for my response. When I gave none, he said, “They didn't want us here." The silence that fell between us did not mitigate the force of that prohibition. This man has white hair and a pink and white Irish-looking complexion, but his name, his heritage, and where he lived made him an outcast just a couple of miles south of the Vardy valley.

These two exchanges stood out and, for me,- became defining moments. In each case, an almost offhand reference to exclusion of Melungeons from Hancock County society brought the conversation, flowing easily just moments before, to a standstill. As I 
wrote up my field notes and began reflecting on what I had heard, both remarks about being on the outside, excluded, stood out. I realized I was glimpsing the center of the Melungeon experience through a lens I had not had before- the experience was not about how a person was designated on census records or whether he or she paid taxes. Instead these remarks told how people had to live their lives informed by a hidden literacy — what people know about each other and how that knowledge shapes the way they interact.

Reading, thinking, talking, and writing about the Melungeons for seven years now has rendered their saga familiar. I have to look hard to find new information. Yet, these two separate comments went to the quick and made me re-evaluate ideas that had become comfortable. In fact, they brought me back again to one of the earliest insights of my Melungeon research odyssey — that being Melungeon and living there, on the inside, is much different from learning about Melungeon history and making judgments, from the outside. No matter how many times I visit Vardy, no matter how many Unions I attend, no matter how many books and articles I read, no matter how many people I interview, no matter how many tapes or CDs I listen to, I will always be on the outside bringing my academic presuppositions and my personal history of middle class privilege into this palpably different and distinctly Appalachian reality.

Then, in case I hadn't gotten the point, this disjunction was underscored a second time in an exchange I re-read in Appalachian Journal. Chris Everett is a historian who was working on his Ph.D. at Vanderbilt when he wrote "Melungeon History and Myth." In his lengthy essay, Everett carefully reviews print literature about Melungeons as well

\footnotetext{
${ }^{1}$ C.S. Everett, “Melungeon History and Myth,” Appalachian Journal 26, no. 4 (1999): 358-409.
} 
as discussing the possible etymology of the name. He summarized his conclusions in an email message that was subsequently posted to Melungeon-L:

I say the "Melungeons" aren't Melungeons, because there has never been a historically definable "Melungeon" ethnicity, no one group of people has ever claimed to be "Melungeon," and most individuals so-called have denied it. The people have consistently claimed descent from Indian ancestors, and there is good $19^{\text {th }}$ and early $20^{\text {th }}$ century documentation that suggests that the first "Melungeons" in Tennessee were actually "friendly" Indians from Virginia, who were only called "Melungeon" by certain white folks_-"Melungeon" was nothing but a put-down. So, that's it in a nutshell. ${ }^{2}$

In addition, another point he made in the course of his article was that the claim by some Melungeon people to Portuguese ancestry is bogus. He alleges that from the 1800 s to the present "Portuguese" has been a euphemism for African and that people wishing to identify with Europe rather than with Africa as a place of origin have used it as a selfdescriptor. Yet, Melungeon people have long claimed they were "Portyghee" and told inquirers (journalists and researchers) so. Everett tried to trace this claim using traditional scholarly research tools and found no substantiation. From my vantage point, I say that Everett did commendable scholarship. He looked at every document he could find including tax and census records in Virginia, North Carolina, the old Southwest Territory, and Tennessee. Then he drew his conclusions. I don't agree with all of them, but I find much in his work that is useful and cannot deny his attention to the record. But, he on the

\footnotetext{
${ }^{2}$ Brenda Collins Dillon, Saponi Article Part 2, posted to Melungeon-L@rootsweb.com, 11 Sep 1999
} 
outside of the Melungeon community is reluctant to heed what descendants say about themselves.

Predictably, Everett's conclusions were not universally accepted; they provoked several letters to the editor. One was from Libby Pearson Killebrew, who said, "I am an east Tennessee Melungeon, descended from the group on which he focuses most of the research in his article." Killebrew goes on to take Everett to task saying he "blindly destroys the integrity of his own research by slandering his colleagues as well as mere amateur genealogists, ... he chooses to trivialize what is admittedly the most romantic story of Melungeon origins [the Portuguese connection], .. . [and he] seems to conclude that the fact ["Melungeon"] has been used as a derogatory term has some bearing on its origin." ${ }^{3}$ Killebrew's most notable allegation is that Everett's attitude approaches white supremacism; her indignation at both his text and what she reads between the lines is apparent in her long letter.

Everett wrote a response that also appeared in AppalJ. He was cautious, but, after all, he had been provoked and called a racist. He says,

My article presents hypotheses; but I argue that I have approached actuality through consideration of a number of factors, not the least of which is the documentary record. . . Killebrew's manner forces me to deal with some of her criticism, particularly her insinuation that I have racist tendencies. Her accusation of slander (though libel is surely the more accurate term) cut fairly hard initially,

\footnotetext{
${ }^{3}$ Libby Pearson Killebrew, Letter to the Editor, Appalachian Journal, 27, no. 2 (2000), 121-22.
} 
until I realized that of course my article "slandered" no one. No colleagues were berated or ridiculed. I engaged only in typical scholarly discourse."4 Typical scholarly discourse. By an outsider. That is the crux of this problem. Researchers in many disciplines are flocking to investigate the Melungeons now; Brent Kennedy's 1994 book, The Melungeons, The Resurrection of a Proud People: An Untold Story of Ethnic Cleansing in America, and his call for scholarly inquiry have borne fruit. However, the discourse of the scholarly community is not the vernacular of many interested readers in Appalachia. Yet, they are reading what the scholars write. People who have lived inside "the legend" are ready to take their places in the society at largeas equals. The "mysterious" Melungeons want the mysteries of their origin solved and are eager for scholars to use their skills to find answers to the questions that have plagued the community for more than a century. However, communication between the Melungeon community (the insiders) and scholars (the outsiders) doing work in such disciplines as anthropology, genealogy, biology, education, literature, and history is difficult because both language and presuppositions differ. It's a culture war in a region where physical violence, not measured scholarly discourse, has often been the preferred problem solver.

\section{AN INTERDISCIPLINARY DEBATE}

Brent Kennedy is a Melungeon descendant raised in Wise County, Virginia; he is the first person who comes to mind when anyone brings up Melungeons. Kennedy embarked on a quest to understand his family history motivated by the fact that he had contracted a puzzling disease that nearly killed him. When that disease was finally diagnosed as

\footnotetext{
${ }^{4}$ C. S. Everett, "Everett Answers Killebrew and Kennedy: A dissenting Voice in the Discourse of Descent," Appalachian Journal, 27, no. 2 (2000), 130.
} 
sarcoidosis, a predominantly Mediterranean malady, he resolved to find out all he could about his genetic background. He had always been told his heritage was Scots-Irish, yet many in his family looked Arabic or Jewish. What he learned in his first six years of genealogical digging is the substance of his book. Kennedy, who calls himself Melungeon, continues to probe for answers to the question "What is a Melungeon?" and “Who am I . . really?” He has encouraged scholars to investigate the Melungeon experience from all angles, and has personally pursued the possibility of a Turkish connection and analysis of his own DNA (apart from the Melungeon DNA project undertaken by Dr. Kevin Jones). His book was not the beginning, but neither is it the end of his story.

In 1994, when his book, The Melungeons, The: Resurrection of a Proud People: An Untold Story of Ethnic Cleansing in America, came out, there was a firestorm in both the academic community and among people who found the book to be an articulation of their lived experience. Kennedy stated up front and subsequently that he was not trying to do scholarship.

I wrote my book purposefully to inspire, encourage, or provoke mainstream academia into taking a more serious — and less dismissive and disparaging — look at not only the Melungeons but at other American mixed-race populations. I stated my intent, my limitations, and my qualifications — and lack thereof — in the opening pages of the book. The book is a manifesto, not an "academic" work, as should be evident from the very first page. People identified with the book because they possessed the same family histories. ${ }^{5}$

\footnotetext{
${ }^{5}$ Brent Kennedy, Letter to the Editor, Appalachian Journal 27, no. 2 (2000): 124.
} 
Although an academic himself, Kennedy is neither historian nor genealogist. His invitation to scholars and the allegations in the text itself were a challenge, and it didn't take long for two scholars to respond. David Henige, a historian at the University of Wisconsin, in a review of The Melungeons asserts that Kennedy, whatever he may claim to be doing, is writing history, "in the usual prescribed fashion by culling through historical sources to reconstruct some portion of the past in line with a particular theory." ${ }^{6}$ Henige, whose 1984 Appalachian Journal article "Origin Traditions of American Racial Isolates: A Case of Something Borrowed," positions him as a scholar long focused on mixed-race populations, went on to say, "Kennedy clearly views his work as an ongoing enterprise, so perhaps it would be expedient for him to publish as soon as he can the documentation for the 100 or so assertions than now lie exposed and undefended in The Melungeons. Until he does so, whatever credibility his argument might have is fatally compromised."7

Another scholar, Virginia DeMarce, past president of the National Genealogical Society, is as indignant as Henige at what she sees as sloppy research and unsupported conclusions. In her review of Kennedy's Melungeons she writes:

Mercer University Press has placed its imprimatur on a book that attempts to cross the disciplines of anthropology, genealogy, and history — with genetics as a periodic refrain. However, the author does not apply the standard methodology of any of these disciplines. Racial prejudice and persecution, as the title implies, are the themes that meld all this together. . . no evidence-not even census records, . . not a single instance in which his named ancestors, from 1790 through 1900,

\footnotetext{
${ }^{6}$ David Henige, "Brent Kennedy’s Melungeons," Appalachian Journal 25 (1998): 271.

${ }^{7}$ Henige, "Brent Kennedy's Melungeons," 278.
} 
appear in public documents as anything but white. ${ }^{8} \ldots$ Other links, relationships, and conclusions do not withstand fact checking. ${ }^{9}$

Both de Marce and Henige refuse to recognize Kennedy's narrative and experience as valid. They insist that every allegation must have documents-census records, tax rolls, birth and death certificates - behind it. They refuse to acknowledge that lived experience and family stories could be legitimate contributions to the unfolding Melungeon story.

Enter scholar \#3. In the same AppalJ issue with Henige's scathing book review is an article by Darlene Wilson, a Ph.D. candidate in history at the University of Kentucky. Wilson grew up with Brent Kennedy in Wise County. She has one foot solidly in each camp —academia and Appalachia. Her article, titled "A Response to Henige," is interesting for both what it says and how it is written. Says Wilson:

I immediately recognized in Kennedy's theories a probing attempt to recount the real experiences of so many of our neighbors and, yes, of probably my own ancestors. I . . . came to the conclusion that Kennedy had, albeit incompletely and with errors of fact and omission (of which I have been reminding him goodnaturedly ever since), opened the closet door on Appalachia's ugly history of racism, caste- and class-differentiation, and showed that it isn't ancient history but something quite current. ${ }^{10}$

As a scholar Wilson says she agrees with Henige's allegation that a definitive history of the Melungeons has yet to be written. In addition, she puts her finger on one probable reason for Henige's dismay: “A quick glance at Kennedy's slender footnotes won’t turn

\footnotetext{
${ }^{8}$ Kennedy does admit that his ancestors were classified as white on page 6 of his book and then explains why being "officially" white was not enough.

${ }^{9}$ Virginia Easley DeMarce, "Review Essay: The Melungeons," National Genealogical Society Quarterly 84 (1996): 134, 137. 140.

${ }^{10}$ Darlene Wilson, “A Response to Henige,” Appalachian Journal 25 (1998): 287-88.
} 
up any reference to Henige's 1984 article or to any of his other writings on related topics. Which puts Henige's tone in perspective: Hell hath no fury like a scholar ignored."11 Granted, Henige and de Marce make valid criticisms based on their understandings of scholarship in their disciplines. However, there is another possible position. Kennedy claims that the documents only tell one kind of truth. His book that is based on experience and oral history tells another.

Wilson is very aware of the disconnect between the two discourse communities she participates in. She points out that Kennedy's book sent tremors through both:

This book has (as of November 17, $1997^{12}$ ) sold 10,600 copies, roughly three-tofour times the average initial sales of an academic work by any university press, especially a minor one. Kennedy's book is indeed considered a single family's history by the readers I have heard from; only a fraction of that audience are academics. Thus we need to consider The Melungeons' impact among a predominantly Appalachian-connected lay-readership. ${ }^{13}$

Later in her piece she gives examples of statements from Appalachian readers who felt a quickening in themselves when they read Kennedy's book because they personally identify with the picture of secrecy and second-class citizenship he paints. Says Wilson, “These people would never read Henige's work, mainly because his audience consists of other scholars accustomed to his elitist writing style but also because Henige, in his 1984 essay and in this one, is patronizing."14

\footnotetext{
${ }^{11}$ Darlene Wilson, "A Response to Henige," 288.

${ }^{12}$ Kennedy's book has sold 30,000 copies as of February 2006.

${ }^{13}$ Darlene Wilson, "A Response to Henige," 287.

${ }^{14}$ Darlene Wilson, "A Response to Henige," 289.
} 
Wilson's message is on target and her prose is compelling; she wants both of her audiences — the scholars and the Appalachian-connected lay readership — to understand what she says. She displays her scholarly mettle (Henige's disagreement about that not withstanding) and yet uses language that everyone can understand. I have not seen her comment on Chris Everett's work, but my guess is that she would both appreciate his position and understand why "Melungeon History and Myth" upset Libby Pearson Killebrew. Wilson bridges the rhetorical gap.

Brent Kennedy, like Wilson, is one who can bridge the gap between the scholarly community and the laity. After all, he grew up in Wise, Virginia, and never forgot his beginnings. ${ }^{15}$ Where he grew up, all the study he has done, and how passionate he is about his beliefs have formed him. Kennedy is always the center of controversy. When he initiated his family studies and began gathering the material that became his book, some relatives destroyed photographs rather than allow him access, and others told him to "burn in hell."16 He even received death threats. As recently as June of 2003, he entered into a protracted debate over email with Jack Goins, a prominent Melungeon genealogist, about the DNA testing undertaken by Dr. Kevin Jones of the University of Virginia at Wise and the interpretation of the results. There are definitely pro-Kennedy and antiKennedy factions among both scholars and Melungeon descendants themselves. Nonetheless, he is the de facto and most visible leader of the Melungeon "movement,"

\footnotetext{
${ }^{15}$ There are two areas in Appalachia where people of Melungeon descent are historically found-the Vardy Valley north of Sneedville in Hancock County, Tennessee, and the Coeburn Mountain area near Wise and Coeburn, Virginia. People in both areas share some common ancestors and experienced discrimination and prejudice in similar ways. The Vardiman Collins family comes from Vardy; Kennedy's ancestors - the Canadays, Mullinses, Colleys, and the Nashes_come from Coeburn Mountain.

${ }^{16}$ Ted Anthony, "Forging a Common Present from Mysteries of Long-Hidden Past Lineage: A Quest for Ancestral Secrets in the Appalachians Leads a Researcher to the Melungeon People - and to Controversy," Los Angeles Times, 28 June 1998, Bulldog Edition, A:1.
} 
and others often define their positions in relation to his statements. His ability to function in both discourse communities and his personal charisma are certainly reasons for his prominence.

I, too, am keenly aware of these two discourse communities. I want to satisfy both - to do meaningful scholarly work and to contribute to the growing body of texts in Melungeon studies as Melungeon descendants continue to press for answers to their persistent questions: "What is a Melungeon?" and "Who am I . . really?"

In addition to this issue of audience, there is a second difficult problem in Melungeon research: how to value and integrate the oral tradition. Scholars like David Henige and Virginia de Marce and Melungeon genealogists like Jack Goins insist that the documents are the touchstone and the only way to verify history. Brent Kennedy and Darlene Wilson argue for a broader scope and for listening carefully to the stories handed down in families and communities. Kennedy tells anyone who will listen about how the courthouses in the Melungeon counties burned, sometimes repeatedly, turning written records to ashes, and he also notes in print, "[R]eliance on written records alone has its pitfalls." ${ }^{17}$ Wilson further explains the difficulties that people with Melungeon heritage looking for documents to solidify their conclusions often encounter. It is not just the absence of documents, but the fact that they are confusing. Family lore handed down orally can sometimes supply missing links. Writes Wilson:

Although some of [my] non-academic correspondents have indeed read Kennedy's work, they often are novices at genealogy who have become frustrated with the glaring inconsistencies of documentary "proofs" such as those relied

\footnotetext{
${ }^{17}$ Brent Kennedy, Letter to the Editor, 126.
} 
upon by Henige and DeMarce. They find an Appalachian ancestor listed on one census as "white" but curiously absent on the next, and on another as "mulatto" and on yet another as "F.C." (free colored), and they want to know what this could mean. ... Or they relate memories like that of another Wise Countian, teacher Connie Clark, whose grandmother "hid" herself and her granddaughters from the Census-taker as late as $1960 \ldots$. . Like Kennedy and Clark, these readers also heard their allegedly "Scotch-Irish" relatives and in-laws whispering to each other, trying to hide the remnant effects of Jim Crow legislation and the eugenics movement on their lives. . . Plentiful evidence exists that Census-takers either lied or were lied to, fudged their "returns," or otherwise delivered contaminated data. $^{18}$

If the courthouse burned to the ground and the census taker was bribed or lied on his own account, what is left to the family historian?

Brent Kennedy found that not even the oral tradition was easy to access. It was difficult to find people who would talk, and even when they did they refused to be quoted. In his book he says:

As I now know, the truth had been hidden, generation after generation: photos and family records burned time and again as each generation tried to eliminate evidence of the one that preceded it. The truth constantly altered to "protect" the generations that followed. The young and the old torn between remembering and denying one another. ... we were "free persons of color," or simply "FPC" as the early census takers had coined in shorthand. Some of us achieved the prized

\footnotetext{
${ }^{18}$ Darlene Wilson, “A Response to Henige,” 289.
} 
"white" classification . . but were still treated as FPC by [our] neighbors who made judgments purely on physical characteristics. And being FPC — or simply associated with FPC - was the ultimate sin. A stigma that permanently isolated its victim from the rest of so-called civilization. Neither white, black, mulatto, nor Indian, the Melungeons were left to fend for themselves, a people who were, as numerous writers have so often stated, "nobody at all.",19

So, I have come full circle. The conversations I had with my informants at Vardy re-sensitized me to the situation for both Melungeon people and for those who would do research about and among them. It is more than a matter of looking things up. Even when the documents tell a story, the researcher must also read between the lines and listen to the voices because the truth may be veiled. She must also know her own biases and be aware of pressures on all concerned from a variety of sources: pressure from scholarly colleagues, peer pressure on informants, the assumptions that are taught along with literacy, the strict codes of mountain life, desire to please multiple audiences, effects of religious beliefs, and surely more. Then, too, she must determine how to package her product to reach appropriate audiences. Melungeon research is anything but simple.

I am Appalachian by choice; I didn’t grow up in the mountains. If I had, my mother, like many hillbilly mothers, might have told me "You be good now, or the Melungeons'll git ya!" Hearing such an admonition, I probably would have straightened right up and done what I was supposed to. This commonplace was widespread throughout the highlands and, although used in jest, it was meant to strike fear in the heart of a child.

\footnotetext{
${ }^{19}$ N. Brent Kennedy with Robyn Vaughn Kennedy, The Melungeons, The Resurrection of a Proud People: An Untold Story of Ethnic Cleansing in America, (Macon, GA: Mercer University Press: 1994), 5-6.
} 
I used to be quick to respond when people asked me "What is a Melungeon?" In my book about Melungeon characters in fiction, I said,

Melungeon is convenient shorthand and a powerful metaphor. Melungeon says mystery, unpredictability, isolation, prejudice, passion, volatility, superstition, adventure, and pride. Melungeon suggests a predisposition toward making a drinking "shine," a knowledge of herb medicine, fetching dark-skinned blue-eyed women, handsome reckless men. It conjures a vision of living free on misty ridges, knowing one's own way apart from the monotony of urban America, challenging death in church by eyeballing a rattlesnake or a copperhead, and painting colorful figures with bold strokes against a background of poverty and prejudice. $^{20}$

I still stand by that statement. However, it is easier to analyze the fiction than it is to complete the puzzle of origins, genetics, prejudice, disagreements, and attitudes that come into play with real people. Characters are simply who the author created them to be, but many of the people I have met are complex and mercurial - their lived experience has left marks on them that cannot be erased. Now I find it hard to know what to say when someone asks, "What is a Melungeon?" and often reply, "How much do you want to know?" because "Melungeon" can mean different things in different situations.

It is clear that the Melungeons are a distinctive feature of Appalachian life. But, their story is not the one that American children learn in history books. How and when the Eurasian ancestors arrived on this continent is not clear. Which Indians contributed to the gene pool is not known. Why the dark people came to the ridges of the mountain

\footnotetext{
${ }^{20}$ Katherine Vande Brake, How They Shine (Macon, GA: Mercer University Press, 2001), 280.
} 
South and why they stayed when things were so bad for them is not understood. What is becoming clear is the path ahead. They were excluded from the white society around them, yet they persevered.

Literacy was not a condition they could take for granted, since most schools were closed to these marked people. Rather than attend schools for Negroes, they boycotted school altogether. Their tax money on the land they owned was welcomed in the county coffers, but they did not enjoy the right of suffrage. When their titles to land were challenged, they could only claim access to the court system if the opponent was a Melungeon: they were not allowed to testify against a white person. Reading and writing came late, and schooling was often the prelude to outmigration from the hills and valleys they called home. My purpose in this dissertation is to explain how some people of Melungeon descent dealt with exclusion and surmounted the barriers the racist society erected. Particular foci will be various literacies and literacy practices-education that occurred at the Vardy Community School and exploration of the ways that Melungeon descendants and others claiming Melungeon ancestry are establishing community and exploring their identity using the Internet. I will reconstruct the last century of Melungeon life in light of recent theories of learning and literacy and analyze both Melungeon websites and the Melungeon email list. 


\section{Chapter 1}

\section{Definition and Speculation: What "Melungeon" Means and Where They Originated}

\section{THE TERM “MELUNGEON”}

People in Appalachia know what "Melungeon" means. Journalist Ted Anthony has as good a handle on the mountain understanding as anyone:

For 300 years, racial, social, and cultural stigmas made second-class citizens of anyone in this region who was branded with that one word. Scattered in pockets through the mountains, they sat at the bottom of the white trash pilediscriminated against, denounced, denied voting rights, branded "colored" by the government in the days when that was a fighting word. ${ }^{1}$

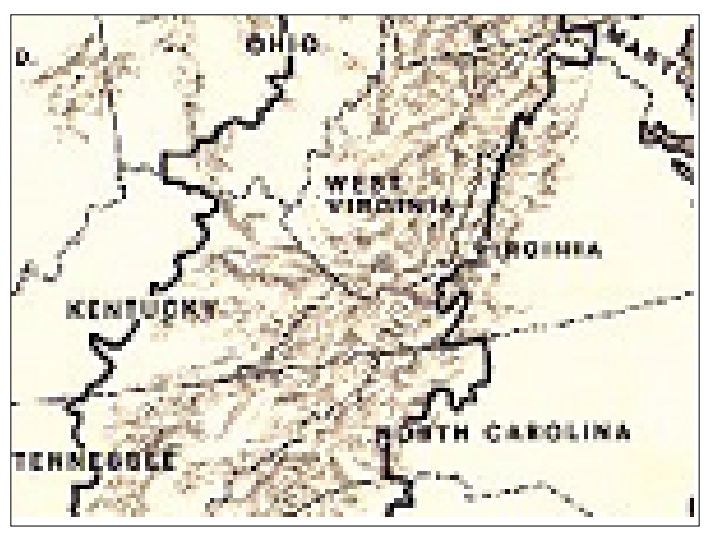

Many Melungeon descendants call the area where Kentucky, Virginia, and Tennessee meet home.

\footnotetext{
${ }^{1}$ Ted Anthony, "Forging a Common Present," A:1.
} 
Most dictionaries say that "Melungeon" comes from the French mélange, meaning "mixture." Since Melungeons are mixed-race people, this derivation makes sense. Chris Everett bolsters this point of view by telling the story of Tubeuf's French colony that was established in 1793 or 1794 near Fort Blackmore on the Clinch River. The first written use of the word "Melungin" was in the minutes of the Stony Creek Primitive Baptist Church on September 26, 1813, in what is now Scott County, Virginia, near High Knob. Records show that persons with typical Melungeon surnames (Gipson, Collins, Maner, Sexton) migrated into the area of Stony Creek from 1801 to $1804 .^{2}$ These people are noted in the church records; they eventually disappear presumably moving south and west to Blackwater and Mulberry Gap just north of the Newman's Ridge/Vardy community. Everett cites the church minutes as the first pejorative use of the term "Melungin."

Then came forward Sister Kitchen and complained to the church against Susanna Stallard for saying she harbored them Melungins. Sister Sook said she was hurt with her for believing her child and not believing her, and she won't talk to her to get satisfaction, and both is "pigedish," one against the other. Sister Sook lays it down and the church forgives her. Then came forward Cox and relates to the church that he went to the Association and took the letter and they received the letter in fellowship. Dismissed. ${ }^{3}$

Everett thinks it logical that the word "Melungin" is used in a negative way about persons who were censured or excommunicated from the fellowship in an area known to have

\footnotetext{
${ }^{2}$ C. S. Everett, "Melungeon History and Myth," 361 \& 392.

${ }^{3}$ Minutes of Stony Creek Primitive Baptist Church, Scott County, VA, September 26, 1813. http://ftp.rootsweb.com/pub/usgenweb/va/scott/church/stonycrk.txt Accessed 20 July 2003.
} 
French settlers. ${ }^{4} \mathrm{He}$ bases his deduction about its negative connotation on the fact that no persons with Melungeon surnames were listed in the records when the term was applied; "[i]t is worth noting that while 'Negro' and 'black' are utilized in several instances throughout the minutes as descriptive terms for a few church members ('white' never being used). 'Melungins' was used but once and not while the people being referred to as such were sitting in Stony Creek church. " Everett does not comment on what "pigedish" might mean even though one Melungeon website puts "prejudiced" in parentheses.

Another common theory about the etymology of the word "Melungeon" is that it comes from the Afro-Portuguese word melungo or malungo. This word means shipmate, especially in the sense of persons who came west from Africa on the slave ships. David Henige traces it from Kongolese phrase mu alungo meaning "in the same boat." In Brazil the term gradually came to mean "children who were nursed at the same breast." A further evolution of the term meant "buddy," "pal," or "chum"; in Spanish, especially Puerto Rican Spanish where the word malungo means "plump" or "chubby.",

A third possibility is the Greek $\mu \varepsilon \lambda \alpha \sigma$ (melas) that means "black." Kennedy tells how his mother was only allowed to play outside in summer if her arms and legs were completely covered, so that exposure to the sun would not turn her skin, with its high melanin content, very dark. Nancy Hopkins would turn a shade darker than a fashionable $\tan$.

Brent Kennedy, in line with his Turkish origin theory, claims that "Melungeon" comes from the Arabic melun jinn and the Turkish melun can. Both of these words are

${ }^{4}$ C. S. Everett, "Melungeon History and Myth," 368

${ }^{5}$ C. S. Everett, "Melungeon History and Myth," 362.

${ }^{6}$ David Henige, "Brent Kennedy's Melungeons," 280.

${ }^{7}$ C. S. Everett, "Melungeon History and Myth," 372.

${ }^{8}$ C. S. Everett, "Melungeon History and Myth," 372. 
pronounced similarly to "Melungeon" and mean "cursed soul.", I have heard Kennedy say that he thinks Melungeons applied this word to themselves to describe their situation in life.

Contributors to the Melungeon email list, Joanne Pezzullo and Karlton Douglas, relate "Melungeon" to the English word malengin (s.) malengine (pl.) that means "ill intent," "deceit," or "guile." This word occurs in the Magna Carta and Spenser's Faerie Queene. They support their theory by saying, "It is well-known the people of Appalachia, and Melungeons in particular, used words that were becoming archaic, and not much in use beyond Appalachia."

In addition, Everett suggests one more possible origin — the Italian word melongena related to the more modern Italian word melanzane. This word means dark skin, like the skin of an eggplant, and was used to describe dark Italians. It has also been considered a racial slur against persons with black African heritage. ${ }^{11}$ He suggests that this meaning is possible because of Italians who settled in Virginia as early as 1621 in a location where Melungeon ancestors were known to be.

However the term originated, nearly all who have written about Melungeons agree that Melungeons themselves hated the name. Jean Patterson Bible, in her 1975 book Melungeons Yesterday and Today, wrote, "[w]herever the name came from, up until recent years, Melungeons were justified in resenting it as it was always used as an

\footnotetext{
${ }^{9}$ Wayne Winkler, "A Brief Overview of the Melungeons," http://www.melungeons.com/articles/january_2003.htm Accessed 17 July 2003.

${ }^{10}$ Joanne Pezzullo and Karlton Douglas, "Melungeon or Malengin?" http:?? www.angelfire.com/tn3/youngeagle/MELUNGEON or_MALENGIN.htm Accessed 15 July 2003.

${ }^{11}$ C. S. Everett, "Melungeon History and Myth," 373.
} 
expression of contempt or a disparaging implication." ${ }^{12}$ W. C. "Claude" Collins related in one of his talks at Fourth Union how he came home to Newman's Ridge from the University of Tennessee talking about the William Worden article (1947) from the Saturday Evening Post titled "Sons of the Legend." ${ }^{, 13} \mathrm{He}$ told his mother that there were pictures of their relatives in that national magazine and that they were called "Melungeons:" "Don't you ever use that word!" she admonished him. For Collins and his relatives on Newman's Ridge, "Melungeon" was anathema.

The Stony Creek Baptist Church minutes' reference and print uses of the word in the 1840s and 1850s in Littel's Living Age and The Jonesboro Whig and Independent definitely have a pejorative tone. These documents, as well as stories related to Wayne Winkler by people he knows and/or is related to caused him to comment "The common usage of the term had an element of socio-economic status attached to it; families who were financially successful were not necessarily considered Melungeon, no matter what their ancestors were. ${ }^{14}$ Wilson says the same thing in AppalJ when talking about Brent Kennedy's family, “In 1950, his parents were well-known members of a community whose fortunes rose and fell along the cutting edge of American industrialization; by my reckoning, they lived fairly well and considerably 'up' on the social ladder, such as existed for that time and place, but they could hold that status only as long as they renounced their colorful ancestry." 15

\footnotetext{
${ }^{12}$ Jean Patterson Bible, Melungeons Yesterday and Today, (Rogersville, TN: East Tennessee Printing Co., 1975), 13.

${ }^{13}$ William L. Worden, "Sons of the Legend," (Saturday Evening Post 18 October 1947: 28+).

${ }^{14}$ Wayne Winkler, "A Brief Overview of the Melungeons," (http://www.melungeons.com/articles/january_2003.htm) Accessed 17 July 2003.

${ }^{15}$ Darlene Wilson, "A Response to Henige," 293.
} 
Furthermore, conversations I have had with other Melungeon descendants affirm that they knew the term from their earliest awareness, but it was something no one ever talked about openly. Everett summarizes precise uses of the word in the print record and states,

Melungeon implies mixed racial ancestry. It has most often been used in reference to people of American Indian descent. But the implications of the term also suggest some African-American ancestry, and the term has also probably been used in reference to individuals who have some remote black heritage.... The historic record indicates that the term connoted "mixed blood" and very probably "mixed blood Indian in a generally Negrophobic society placing too much stock in the concept of blood "purity."16

Not until the emergence of the Melungeon community on the Internet in the 1990s have people clamored for inclusion in this group.

\section{SO, WHAT IS A MELUNGEON?}

Scholars and most people in Appalachia agree that the Melungeons are people of mixed ethnic ancestry found in specific geographic regions in the mountains of Northeast Tennessee, Southwest Virginia, and Eastern Kentucky—more specifically in Tennessee Newman's Ridge and Vardy in Hancock County; in Virginia Stone Mountain or Coeburn Mountain in Wise County, Blackwater in Lee County, and an area known as Ramptown near Dungannon in Scott County; Magoffin, Letcher, and Knott Counties in Kentucky, and Carmel in Highland County, Ohio. Several surnames are common among Melungeon

\footnotetext{
${ }^{16}$ Chris Everett, "Melungeon History and Myth," 386.
} 
people in all these regions, including Bowlin (Boling), Bunch, Collins, Gibson (Gipson), Goins, and Mullins.

These facts are things that can be written down and learned. I knew these things when I drove up to Sneedville the first time for the Fall Festival in October 1999. The facts came into focus for me when I met R.C. Mullins, a founding member of the Vardy Community Historical Society. When I saw him face-to-face, I began to understand: some Melungeons look different, despite the fact that in this day of political correctness, such a statement is likely to be misconstrued. Yet, I am not the only one to notice the difference. Two different times I have taken friends with me on research forays and introduced them to self-acknowledged Melungeons. On the way home each of them said, "You tried to explain about how the Melungeons look, ... and now I understand." There is no substitute for lived experience. Writer Ted Anthony, in his Los Angeles Times article makes the same observation: “Though they fit our nation's modern definition of white, many with Melungeon ancestry look different from the majority of white folks around here [Wise County, Virginia, his research site]. Long regal noses, dusky faces, jetblack hair, shining blue eyes. One glimpse can evoke foreign lands, strange tongues." ${ }^{17}$

Both popular and scholarly writers have spilled much ink speculating about Melungeon origins, and by "origins" they mean non-Indian origins. Most scholars and genealogists, be they amateur or professional, agree that one important element of the Melungeon mix is Native American. C. S. Everett argues that before the people who became known as Melungeons appeared in East Tennessee and Southwest Virginia, they lived in close contact with known Indian tribes - Catawba Indians in Macon County,

\footnotetext{
${ }^{17}$ Ted Anthony, "Forging a Common Present," A:1.
} 
North Carolina, Saponi and Monacan Indians in Amherst County, Virginia. ${ }^{18}$ Early written accounts of Melungeons by Will Allen Dromgoole in 1891 and Lewis M. Jarvis in 1903 call the family groups "tribes."

Darlene Wilson puts a different spin on the debate about origins, by pointing out that many who would support one theory or another are mainly concerned with the male progenitors. She, on the other hand, reminds her readers that there would have been no Melungeons without the cooperation of female natives. The "male offshore others" could have come from many different Eurasian and African home ports, but there would have been no Melungeon descendants without the North American women. Writes Wilson:

I will continue to argue that the reason Melungeon history is shrouded in confusion is that it cannot be gleaned or told unless one is willing to consider the perspective of the women who bore these children that would call themselves Melungeon or who suffered under its label. Anti-miscegenation legislation and sanctions, until the Supreme Court's 1967 ruling (Loving v. Virginia), declaring such to be unconstitutional were held to apply mainly to women. We will locate the history of Melungeon people in the conflict between Anglo-American patriarchy and native matriarchy, a conflict that in Appalachia has yet to be resolved. ${ }^{19}$

Wilson's point is well-taken, but there is yet another point of view. The latest research project investigating the question of origins, the DNA studies of Dr. Kevin Jones, is showing some surprising possibilities. There has been much debate about the wisdom of participating in a DNA study among Melungeon people; conversation about

\footnotetext{
${ }^{18}$ C. S. Everett, "Melungeon History and Myth," 365-66.

${ }^{19}$ Darlene Wilson, "A Response to Henige," 294.
} 
the DNA project waxed and waned on the Melungeon email list for more than two years. Although an official report of the study has not yet appeared in a refereed journal, Jones gave a preliminary report at Fourth Union, the bi-annual Melungeon gathering, in Kingsport, Tennessee, on June 20,2002. The major thrust of the study was analysis of mitochondrial DNA, the genetic material that is passed from mothers to their children. Jones stated that the study of the samples showed the maternal lineage of the Melungeons to be "multiracial": 5\% reflect Native American ancestry, another 5\% reflect an AfricanAmerican ancestry, and the rest fall into the Eurasian category. ${ }^{20}$ There has also been some work done in the study on the male lineages of the Melungeons who contributed samples through Y chromosomes; 20 samples were looked at in the research before Jones's presentation. Although he cautioned his listeners at the Union that the number was too small a basis for the drawing of conclusions, he noted that the samples did reveal a very diverse range for the male lines.

\section{ARE MELUNGEONS SIDDI?}

In a speech at the Union and a subsequent written statement that was posted on the melungeons.com website, Brent Kennedy was quick to pick up what he saw as important implications of the DNA study information. Of the large proportion of sequences of mitochondrial DNA labeled "Eurasian," 7\% matched populations in Turkey, Syria, and Northern India. Said Kennedy, "The long discounted Mediterranean and Middle Eastern heritages are irrefutably there. ${ }^{, 21}$ Kennedy claims he is still keeping an open mind about

\footnotetext{
${ }^{20}$ Kevin Jones, "DNA Study Results," a presentation at Fourth Union, 20 June 2002, Kingsport, TN.

${ }^{21}$ Brent Kennedy, "A New Path,"

(http://www.melungeons.com/articles/a_statement_from_brent_kennedy.htm) Accessed 22 July 2003.
} 
origin theories. The most interesting implication Kennedy takes from Jones's study is that some of the "offshore others" had to have been women; otherwise there would be no mitochondrial DNA in the descendants. Kennedy himself is an example of a Melungeon descendant with the "typical" Melungeon phenotype—short stature, wiry build, dark skin, wavy graying black hair, and arresting blue eyes. In the late 1990s Kennedy embraced a Turkish theory of origin. He spoke about this possibility in many venues and initiated detailed linguistic study of Cherokee words with distinctly Turkish roots, trips to Turkey for American Melungeon descendants, and sister city designations for Wise, Virginia, and Cesme, Turkey. When he learned about his own DNA sequence and what that might mean about his personal ancestors, he wove the facts into one possible origin scenario that is worth reading because it shows how the longing to know where he came from is playing out in his thought. His position as a leader in the Melungeon movement gives his words added weight for some readers:

My mitochondrial DNA, which I inherited from my Mother, matches the Siddis of India. The dark-skinned Siddis likely originated from what today is Ethiopia, Eritrea, or Somalia—sub-Saharan, East Africa. They were transported to India in a variety of ways, most not so pleasant, and formed a major component of what became known as the Untouchable Caste. Their lives—and the life of my ancestral Mother — must have been horribly difficult. But she survived long enough to have at least one daughter and that daughter did likewise. And generation after generation this original Ethiopian girl's DNA was passed along until, in 1950, it came to me. 
How my particular East Indian ancestor made her way to America remains unclear. It may have been as the wife of a sixteenth-century New World Portuguese settler (the sixteenth-century Portuguese soldiers married northern Indian women by the thousands). Or she may have been the spouse of a seventeenth-century British ex-patriot, or an East Indian female sent to the Caribbean as an indentured servant. Still again, she may have arrived on these shores as a Rom (or so-called, Gypsy) girl. Many Romany share the Siddi mitochondria and the Romany-related surnames that follow this particular mitochondrial line in my family (Mullins, Bennett, Rose, etc.) would seem supportive of a Romany origin. Regardless of her mode of arrival to the New World, what is clear is that she—and her genes—did indeed make their way here. My mother and I are living proof of this woman's legacy. All this to say that had a young, sub-Saharan East African girl never lived, never been transported to India, and never had a daughter of her own, I wouldn't be here. ${ }^{22}$

The other origin theories that Kennedy refers to in passing in his latest Melungeon origin scenario are several and varied. Are the Melungeons Portuguese? A long-standing oral tradition in the Melungeon community is that the dark people are "Portyghee." ${ }^{23}$ This assertion conjures up images of shipwrecks in the "Age of Discovery" when the intrepid Portuguese captain Vasco da Gama rounded the Horn of Africa and explorer Ferdinand Magellan circumnavigated the globe. The shipwrecked sailors were thought to have

\footnotetext{
${ }^{22}$ Brent Kennedy, "A New Path," (http://www.melungeons.com/articles/a statement from brent kennedy.htm) Accessed 22 July 2003.

${ }^{23}$ Jean Bible, Melungeons Yesterday and Today, 95-98.
} 
swum or waded ashore and then vanished into the jungle-like forests of the interior to take Indian women for wives and make their lives in North America.

\section{ARE MELUNGEONS TURKISH?}

Are the Melungeons Turkish or Moorish? Kennedy recounts sea battles in the Caribbean between Sir Francis Drake and his Spanish adversaries that resulted in Drake's taking as many as 600 "Turks" and/or North Africans on board his ships as hostages; Drake's intention was to redeem his captives in the Mediterranean and get as much cash as possible from the Sultan of Turkey. ${ }^{24}$ Drake's logs show that only 100 were actually ransomed. Kennedy presumes that the rest were put ashore when Drake stopped at the Roanoke colony of Ralph Lane and was prevailed upon to transport the discouraged English colonists back to Britain. ${ }^{25}$ There are pieces of linguistic evidence to support this theory. The Turkish melun can and the Arabic melun jinn (both pronounced muh-lun'jun) had to come from somewhere. In addition, Turkish scholars connected to the now defunct Melungeon Research Committee, organized by Brent Kennedy in the mid 1990s, claim that there are as many as 600 Turkish words that can be linked to American English words that have usually been attributed to borrowing from Native American languages, especially Cherokee. $^{26}$

\footnotetext{
${ }^{24}$ Brent Kennedy, Speech at East Tennessee State University (ETSU), 29 September 1997.

${ }^{25}$ Kennedy cites David Beers Quinn, ed. The Roanoke Voyages, vol. 1, series no. 104 (The Hakluyt Society, 1952, as his source for this information about Drake's voyage.

${ }^{26}$ Brent Kennedy, Speech at ETSU.
} 


\section{IBERIAN FOREBEARS}

Could the Melungeons be Spanish? A 1997 book by Eloy Gallegos posits a definite connection to Spanish forebears, which is also a connection to Portuguese people and the rest of the Mediterranean ethnicities. According to Gallegos, Spain was open for centuries to people from southern Europe and around the Mediterranean. Arabs, Jews, Moors, Berbers, and others migrated to Spain whenever they were persecuted elsewhere. Not until the horrors of the Spanish Inquisition ${ }^{27}$ did it become dangerous to be nonnative Spanish. Gallegos and Kennedy both contend that people who feared for their lives signed onto Spanish and Portuguese galleons and set sail for the Americas rather than face torture or death.

Gallegos's book details the "Spanish" presence (which could well have included any one of the ethnic groups mentioned in the preceding paragraph) in what is now the Southeastern United States. ${ }^{28}$ He mentions the expedition of Hernando de Soto in 1540, which traveled up from the Tampa Bay area to what is now Pensacola and then following the rivers and trudging overland, came at least to the present site of Fort Payne, Alabama, and probably to the spot where the Oostanaula and Etowah Rivers join to form the Coosa at today's city of Rome, Georgia. Gallegos narrates in detail, relying on expedition journals in Spanish, about the journeys and settlement attempts by Lucas Vasquez de Ayllon in 1526. Pilot Pedro de Quexo's journal suggests that Ayllon's colony was

\footnotetext{
${ }^{27}$ The Spanish Inquisition was instituted by Ferdinand and Isabella in 1478; one purpose was to root out "conversos," Jews and Moors, who were thought to be insincere. It was administered by Spanish rulers; the Pope in Rome only named the Grand Inquisitor. In fact, the Spanish tribunal was often in direct conflict with the Popes; it lasted until 1820.

${ }^{28}$ Eloy Gallegos, The Melungeons: The Poineers of the Interior Southeastern United States, 1526-1997, vol. 2 of The Spanish Pioneers in United States History (Knoxville: Villagra Press, 1997).
} 
somewhere near St. Catherine's Island south of the Savannah River. ${ }^{29}$ This colonization attempt was unsuccessful: 200 of the 500 settlers died from fevers or Indian attacks. On 18 September 1526, Ayllon himself died, and a mutiny followed. Many of the insurrectionists took to the forests. Only 150 of the original colony group returned to Spain. ${ }^{30}$ No searchers have ever found a trace — not a nail, or a pottery shard, or a bone. Ayllon's settlement exists only in the written accounts.

The theory of origin that Gallegos deems most plausible to account for the origin of the Melungeons is the expedition of Juan Pardo in 1566-67. Gallegos quotes from the journals that Pardo and one of his men kept as they carried out the mandate of King Philip II to claim and hold the land for Spain, to Christianize the native peoples they encountered, and to mark out a land route from Santa Elena (a settlement on the Atlantic coast from 1566-87 at what is now Parris Island, South Carolina) to the confluence of the rivers in Northwest Georgia, the site he labels Chiaha. ${ }^{31}$ Gallegos did extensive fieldwork while researching for his book and claims that he has found the sites of several of Pardo's stone forts. Gallegos's book relies heavily on the journals of Pardo and his lieutenant Juan de La Vandera as well as the extensive fieldwork and includes diagrams of these outposts and speculation based on other records about how long the forts remained viable communities. Santa Elena, a city by wilderness standards, included men, women, and

\footnotetext{
${ }^{29}$ Joseph Judge, "Between Columbus and Jamestown: Exploring Our Forgotten Century,” National Geographic, March 1988, 339.

30 Joseph Judge, "Between Columbus and Jamestown," 339.

${ }^{31}$ Joseph Judge of the National Geographic locates Chiaha further east. The early Europeans made their maps as they traveled into the interior. Some of the landmarks like rivers and mountains are easy to identify, but others, like big trees, have disappeared. There is extant evidence that Cherokees lived in the Rome, Geogia area. Chieftans, a large house of clapboards over a log cabin framework, was the home of a Cherokee named Major Ridge and the site of a ferry across the Oostanaula River. On Mount Alto overlooking the place where the rivers join are the remains of a stone fortification. Gallegos contends this fort was built by the Spanish under Pardo.
} 
children. Its existence has now been documented by recent archaeological excavations. The site was abandoned in 1587, its inhabitants ordered to St. Augustine where a defensive position could be taken against the English who were threatening Spanish domination of the Atlantic and of La Florida. Pardo's men, however, were still at the forts he had established in the interior. There were soldiers and clerics, many of whom undoubtedly took Indian wives. Writes Gallegos, "none drifted back to Santa Elena as they dared not. ... Pardo made no promise nor had any intention of returning to the interior. His orders to the soldier/settlers were to hold the land, a promise to which they swore under oath." ${ }^{32}$ Gallegos is reasonably sure that these men were probably the ancestors of the Melungeons. He claims that the "Spanish faces" of Melungeon descendants and the many Spanish place names throughout the southeastern states are additional evidence.

\section{OTHER THEORIES}

There are other theories that get space in nearly every book-length treatment of the Melungeons. ${ }^{33}$ It is supposed that they could be descendants of Sir Walter Raleigh's "Lost Colony." The fact that the earliest Melungeons spoke Elizabethan English and have some common English family names supports this theory. Another possibility is that the Melungeons are descended from an expedition of a Welsh prince called Madoc. This warrior is reported to have come to Mobile Bay in 1170 and then to have taken a water route north as far as the Tennessee River. There are rumors of blue-eyed, fair-skinned

\footnotetext{
${ }^{32}$ Eloy Gallegos, The Melungeons, 146.

${ }^{33}$ Pat Elder, The Melungeons: Examining an Appalachian Legend, (Blountville, TN: Continuity Press, 1999), 26-36. See also Kennedy's The Melungeons, Bible's Melungeons Yesterday and Today, and Bonnie Ball, The Melungeons, Johnson City, TN: Overmountain Press, 1992.
} 
"Welsh Indians" who built stone forts (perhaps the Old Stone Fort at Manchester, Tennessee) even though there are no records of any Welsh words in any known Indian languages.

Some scholars have thought that the Melungeons' ancestors were seamen from Phoenicia or Carthage who crossed the Atlantic more than 2000 years ago. This hypothesis is supported by the discovery of the Bat Creek Stone, "an enigmatic artifact found in 1885 in Loudon County, Tennessee.... [by] John W. Emmert, an assistant in the Mound Survey Project of the Smithsonian Institutions of American Ethnology. . . By the 1870 s, scholars gave credit to escaping Jews from Rome in the first century." ${ }^{34}$ This Carthaginian theory of origin is also related to Chattanooga Judge Lewis Shepherd's Melungeon case of 1872. Shepherd defended the inheritance rights of a dark-skinned half-Melungeon girl by alleging that she had Moorish heritage (hence her high arches and straight hair). The case was settled in the girl's favor, but Shepherd later admitted he had no "conclusive proof" to support his origin theory. An account of this trial appeared in a Chattanooga newspaper, the Daily American, 26 June 1910, and was widely circulated. ${ }^{35}$

Are the Melungeons "tri-racial isolates"? Scholar Calvin Beale published two $\operatorname{articles}^{36}$ in which he classified all mixed blood people in the Eastern United States as "tri-racial isolates." Beale speculates that groups like the Redbones and the Melungeons are mixtures of Europeans, Indians, and African-Americans blended through intermarriage during and even before the eighteenth century. Even though the term "race" is passé, the "tri-racial-isolate" tag has had a long tenure. Darlene Wilson takes David

\footnotetext{
${ }^{34}$ Pat Elder, The Melungeons, 29.

${ }_{35}^{35}$ Pat Elder, The Melungeons, 27.

${ }^{36}$ Calvin Beale, "American Tri-Racial Isolates, Their Status and Pertinence to Genetic Research," Eugenics Quarterly 4, no. 4 (1957): 187-96, and "An Overview of the Phenomenon of Mixed Racial Isolates in the United States," American Anthropologist 74 (1972): 704-710.
} 
Henige to task for using the term in his 1984 article, "Origin Traditions of American Racial Isolates: A Case of Something Borrowed." She says "the concept of 'race' as a category signifying anything other than politicized usages has been shot full of holes" and that "[the] second problem with the 'tri-racial isolate' term is embedded in the second word and its inherent suggestion that these population groups were isolated from mainstream America and persisted in some sort of social vacuum." ${ }^{37}$ Wilson goes on to chide Henige for relying on Beale's "outdated" article and on hearsay evidence of "neighbors" to Melungeon descendants he allegedly interviewed in Hancock County. However mistaken or archaic the term may be, the term "tri-racial isolate" still crops up in articles, email postings, and conversations, and it is thoroughly despised. It is not a term I would ever use to describe persons with Melungeon heritage.

It is apparent from the foregoing discussion that the word "Melungeon" has an uncertain etymology and rich connotations. The many origin theories also add mystery and magic to the term. As I concluded in How They Shine, when a novelist labels a character "Melungeon," the word carries a wealth of information: "One word. One lousy word. An obscure word. A powerful word, uttered over the centuries in confusion, derision and, most recently, pride. Melungeon. ${ }^{38}$

\footnotetext{
${ }^{37}$ Darlene Wilson, “A Response to Henige," 291.

${ }^{38}$ Ted Anthony, "Forging a Common Present," A:1.
} 


\section{Chapter 2}

\section{The Powerful Ties That Bind: A Community Created by Shared Experience:}

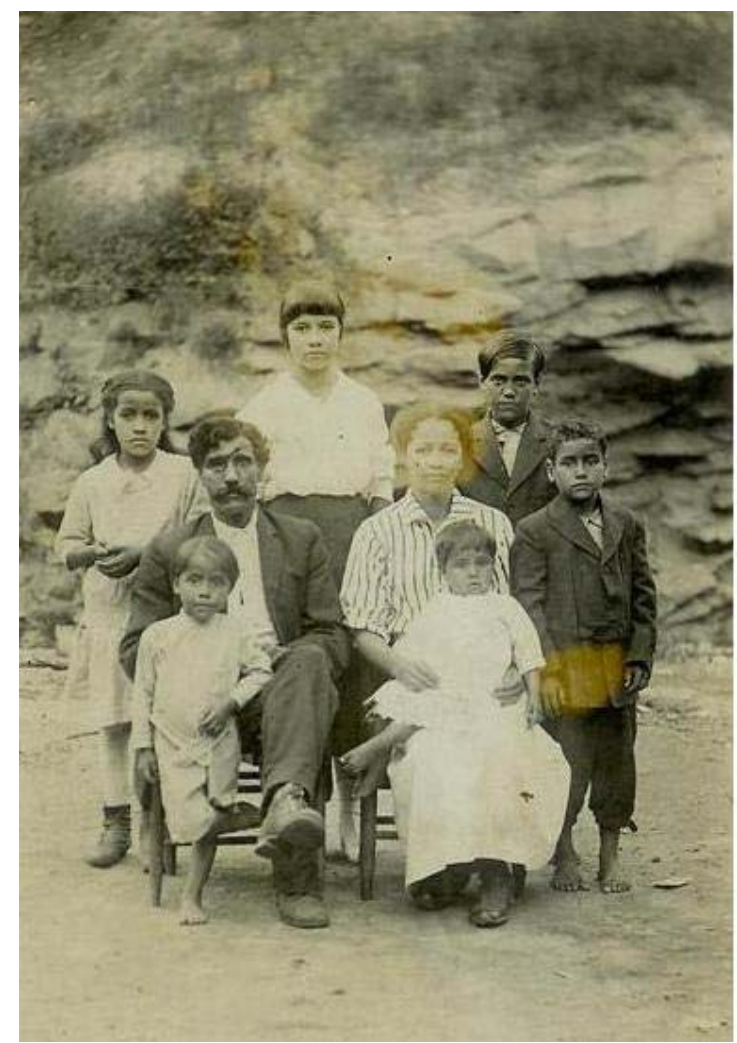

Arch Goins with his wife and children, a Tennessee Melungeon Family about 1920. The characteristic "Mediterranean" features and variation in skin tone are apparent even in this moisture-damaged photograph.

Colorful and interesting as the origin theories are, they are not the center of what it means to be Melungeon. When Kevin Jones, a British national now professor at University of Virginia at Wise, presented his preliminary report on the DNA study at Fourth Union, he 
allowed that his own DNA sequence matches that of someone in the Melungeon population he had tested and then continued:

Does that make me Melungeon?

No.

I have a real sense — and a real inner sense — of what it means to be English. . . .You know what it means to be Melungeon or feel Melungeon. Or to have been discriminated against for being Melungeon. It's a cultural identity that is real and important, but it does not reflect any genetic basis....You are the product of a truly multi-national ... mix of genetic types, but you have that commonality of being Melungeon and knowing what that means. ${ }^{1}$ [Italics mine.]

Many in the Fourth Union audience and many others identify - they feel Melungeon. They have suffered discrimination; they embrace a distinct cultural identity; they share the commonality of being Melungeon; and they do indeed know what being Melungeon means. These shared perceptions and common experiences are cussed and discussed time and again on the Melungeon email lists and constitute a literacy that insiders have first-hand and a familiarity that outsiders apprehend by reading and by listening to the stories.

My take on what it means to be Melungeon comes from reading-every book, article, manuscript, letter, email posting I could find —and from hours of conversation. Several years of tenure as a list subscriber to Melungeon- $\mathrm{L}$ and twenty-five years in Appalachia as a conscious participant in mountain culture inform my perspective. In many cases I choose to present the information and stories that follow in the words of

\footnotetext{
${ }^{1}$ Kevin Jones, "DNA Study Results," 20 June 2002.
} 
Appalachian natives or Melungeons themselves. Most of my informants, be they

published authors or persons I have interviewed, are not scholars in an academic sense.

Many are dedicated to sophisticated research in genealogy or history, but they do not present their findings in scholarly prose. How they talk and write is, I think, as significant as what they say, so I quote my sources extensively. An important part of the essence of Melungiana and of Appalachia is the voices.

\section{THE MELUNGEON LOOK}

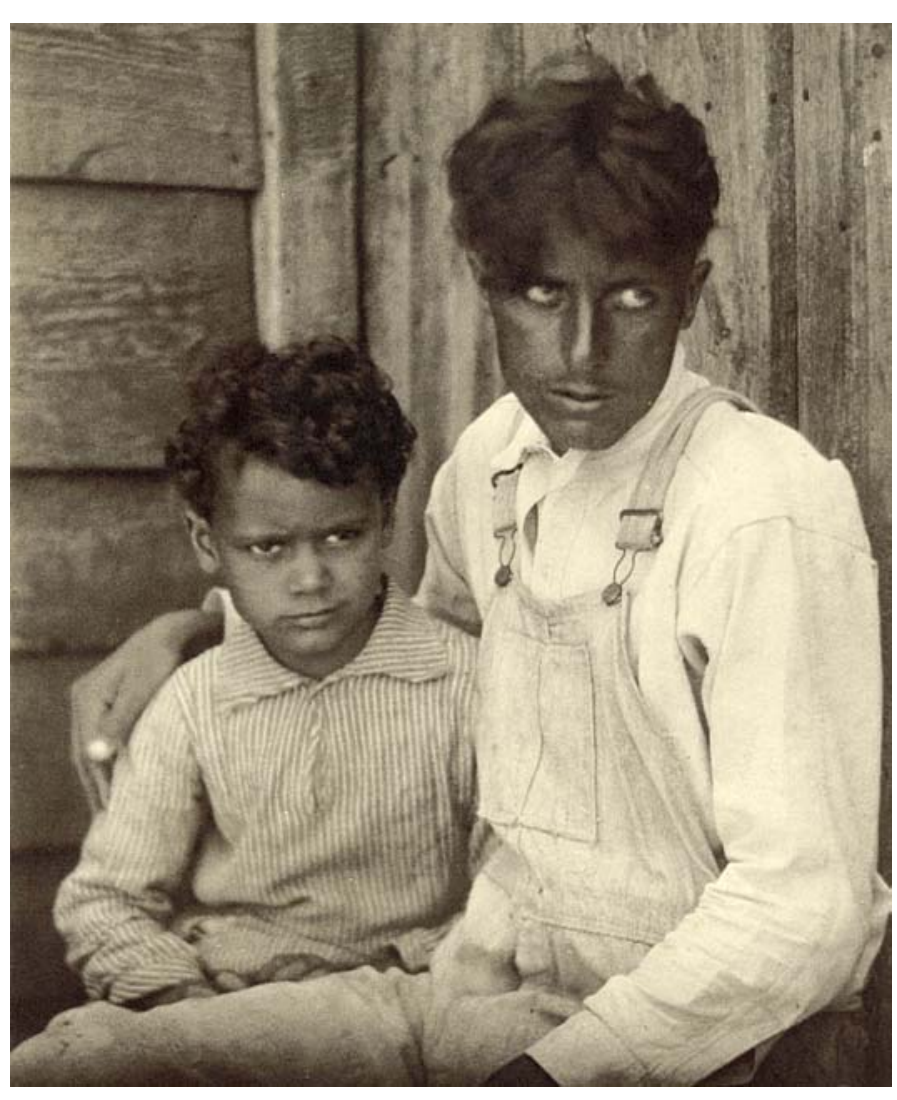

This photo called "Melungeon Boys" was taken by Doris Ulmann; it shows the striking appearance of some who bore the "Melungeon" label. Archived at Berea College; used by permission.
When an Appalachian person says or hears, writes or reads the word "Melungeon," she conjures an image of a dark skinned person. Melungeons themselves share knowledge of the picture that the term is associated with. This, then, is the first characteristic that comes up over and over again, the "Melungeon" phenotype.

Melungeons' dark skin is the trait that excluded them from the larger society. Even as far back as the

Census of 1795, there was a category called "free persons of color" (F.P.C.) for those individuals that could not be placed in the other available categories - White, Indian, 
Negro, Mulatto. Some of these F.P.C.s were free blacks, some probably escaped slaves, and the others were those whose ethnic affiliation was not clear. Melungeon skin color was often described as coppery or olive, hair was usually very dark but could also be red or even blonde and was straight or wavy, eyes could be very dark but were surprisingly sometimes striking blue or flecked hazel. Doris Ulmann's photo, "Melungeon Boys," taken in Kentucky in the 1930s is an unforgettable image. The boys' dark skin and fine features mark them as different from other mountaineers.

While skin color has often been a marker of persons labeled Melungeon, the skin tones within a family were not always consistent. Will Allen Dromgoole was the first person to write about this. She was a journalist and free-lance writer from Nashville, who made a visit of several months to Newman's Ridge in 1890 . She then wrote articles that appeared in newspapers in Nashville and later in Boston's Arena Magazine. Melungeon people thoroughly despise her (she is definitely a part of their shared experience), calling her "Will Allen Damnfool," yet no one denies her profound effect on subsequent descriptions and perceptions of Melungeons. She wrote:

[W]ithin four miles of one of the prettiest county towns in Tennessee, may be found all that remains of that outcast race whose descent is a riddle the historian has never solved. In appearance they bear a striking resemblance to the Cherokees, and they are believed by the people round about to be a kind of halfbreed Indian.

Their complexion is reddish brown, totally unlike the mulatto. The men are very tall and straight, with small sharp eyes, high cheekbones, and straight black hair, worn rather long. The women are small below the average height, coal 
black hair and eyes, high cheekbones, and the same red-brown complexion. The hands of the Malungeon women are quite shapely and pretty. Also their feet, despite that fact that they travel the sharp mountain trails barefoot, are short and shapely. Their features are wholly unlike those of the Negro, except in cases where the two races have cohabited, as is sometimes the fact. ... [T]he pure Malungeons present a characteristic and individual appearance. On the Ridge proper, one finds only the pure Malungeons; it is in the unsavory limits of Black Water Swamp and on Big Sycamore Creek, lying at the foot of the Ridge between it and Powell's Mountain, that the mixed races dwell. ${ }^{2}$

Dromgoole was especially scandalized by families that exhibited a variety of skin colors as the following description shows:

I saw white women with Negro babies at their breasts-Malungeon women with white or with black husbands, and some, indeed, having the three separate races represented in their children, showing hereby the gross immorality that is practiced among them. I saw an old Negro whose wife was a white woman and who had been several times arrested, and released on his plea of "Portyghee" blood, which he declared had colored his skin, and not African. ${ }^{3}$

It is unfortunate that descriptions of Melungeons in so many subsequent articles appearing in the popular press and many of the fictional depictions as well are easily traced back to Dromgoole's prose.

Pat Elder, author of a 1999 book that represents many years of research, notes in her chapter titled "Culture and Genetics" that genetic principles govern the inheritance of

\footnotetext{
${ }^{2}$ Will Allen Dromgoole, "The Malungeons," The Arena 3 (1891): 473.

${ }^{3}$ Will Allen Dromgoole, "The Malungeons," 475.
} 
the typical "Melungeon" traits—skin color, appearance of the hair, and eye color. She states that it is impossible to judge a mixture of types by visual appearance because of atavism or reversion-to-type. ${ }^{4}$ Writers like Dromgoole wanted to imply that children in Melungeon families had promiscuous mothers and ties to Africa, but Elder maintains that "Racial mixing may cause some offspring to bear the impress of one strain of their ancestry and other that of other strains." ${ }^{, 5}$ Elder wants to reduce the genetic principles to a simple list, but she has her facts wrong. The traits she wants to explain — skin tone, eye color, appearance and curliness of hair, and height — are all controlled by multiple genes. Therefore "always" statements about dominance of one trait over another cannot be made about these things. ${ }^{6}$

Another physical characteristic that many Melungeon descendants share is having six fingers. Brent Kennedy, with little provocation, will hold up his hands to show where his sixth digits were. A doctor cut his extra digits off at birth. In fact, there are also other physical traits that tend to appear in families of Melungeon descendants. Description of what Nancy Sparks Morrison calls "ethnic markers" is available on the Internet at a site called Melungeon Health. ${ }^{7}$ She mentions the Anatolian bump or ridge (a half-sphere the size of a golf ball at the base of the skull or a bony ridge where the head joins the neck). She claims, "Only people who live/d in the Anatolian region of Turkey or Central Asia also have this "bump/ridge.", 8 Another characteristic she mentions is a ridge on the back of the front teeth and an outward curve of these teeth, which are called Asian Shovel

\footnotetext{
${ }^{4}$ Pat Elder, The Melungeons, 109.

${ }^{5}$ Pat Elder, The Melungeons, 109.

${ }^{6}$ Moyer, Richard and Charles Owens (biologists), conversation with the author, 16 September 2003.

${ }^{7}$ Nancy Sparks Morrison, Melungeon Health [Website] (2003); available from http://www.melungeonhealth.org/info.html; accessed 23 July 2003.

${ }^{8}$ Nancy Morrison, Melungeon Health.
} 
Teeth. A third ethnic marker is what Morrison terms the "Asian eyefold;" this occurs when at the inner corner of the eye, the upper lid attaches slightly lower than the lower lid. Another characteristic is vitiligo, the loss of pigmentation, which creates blotchy skin, very noticeable in persons with dark skin.

One or another of these traits is often a topic for conversation on the Melungeon email list as was the case in 2000 when the topic was "Melungeon eyes." In the course of the thread of discussion lasting several days, writers mentioned eyes of aqua, yellowishgold, green, sapphire blue, and blue-green with brownish gold specks and a dark brownish ring as well as the dark eyes that one would expect in a person with dark skin. My own experience bears out this array of light colors. The distinctive eyefold mentioned above also contributes to what Morrison calls "sleepy eyes, dreamy eyes, bedroom eyes." One of the most memorable traits of some Melungeon descendants I have met is their striking light-colored eyes.

\section{"MELUNGEON" DISEASES?}

Another part of the shared Melungeon experience is a number of grave health concerns that occupy hours of discussion at the Unions; these diseases seem to be more prevalent in people of Mediterranean descent than in the U.S. population at large. Morrison's medical knowledge is by virtue of personal experience rather than formal medical training. She writes with a tone of authority (both on her website and in postings to the email list) based on her years of struggle with these diseases. There are five major medical problems that she lists as illnesses that seem to occur in Melungeon-connected

\footnotetext{
${ }^{9}$ Nancy Morrison, Melungeon Health.
} 
families: Behcet's Syndrome, Machado-Joseph's Disease, ${ }^{10}$ Familial Mediterranean

Fever, Sarcoidosis, and Thalassemia. It was, of course, sarcoidosis that struck Brent

Kennedy in the 1980s and sent him on the quest to understand his family heritage.

Anthropologist Melissa Schrifft talked with Melungeon descendants at Third

Union in Wise about the physical problems that seem so prevalent. One of her informants said:

Melungeon has a lot of disease. I can't even pronounce all of them. I got problems with my leg. I can't go up step step: I have to take one step, then another one.

They look at me and say, "What's wrong with you?" I say, "I got that ole Melungeon disease but don't ask me what." It works on our lungs and our joints. The doctors say it's arthritis. They think we're so far from the Mediterranean, then don't think we got Mediterranean disease. Now I'm lucky where I live. We have two young doctors, they look for that. They know we got a disease that way. ${ }^{11}$

This person describes very palpable experience of the same sort that Nancy Morrison chronicles on her website. The maladies that frequently occur in Melungeon families have real and debilitating symptoms.

\footnotetext{
${ }^{10}$ There has been no reported case of Machado-Joseph's Disease, a malady that afflicts Portuguese descendants. Medical anthropologist Marie Boutté insists that the disease should not be listed on the website, but Morrison persists in leaving it there.

${ }^{11}$ Melissa Schrift, "Melungeons and the Politics of Heritage" in Southern Heritage on Display: Public Ritual and Ethnic Diversity within Southern Regionalism, ed. Celeste Ray (Tuscaloosa and London: University of Alabama Press, 2003), 117.
} 


\section{"BLACK DUTCH"}

Another commonality the Melungeon descendants share is familiarity with the term "Black Dutch." New list members on Melungeon-L often run into the term when they do genealogical investigation of old records or when they ask family members for stories about their ancestors. Calling someone "Black Dutch" or "Black Irish" was a way to acknowledge the person's dark skin without insinuating a Negro ancestor. Historian Darlene Wilson, in an Appalachian Quarterly piece, relates that her mother's family always said they were "Black Dutch" but could not really explain the phrase:

"Black Dutch" was used in southwest Virginia, southern W.VA, east Tennessee, and east Kentucky, in a context that OFTEN (but NOT always) served to explain away the dark-featured, swarthy, (good) looks of family members who would be right at home (in the sense of physical appearance) among Indians. . . In the aftermath of the so-called "Nat Turner revolt," attitudes hardened toward mixedancestry people throughout the 1830 s and the southern states passed harsh measures to control their lives or to banish them from white(r) communities. ... If you had certain features or skin-tones . . , you and your children could be "rounded-up" and sold into slavery. The term "Black Dutch" ... was thus at hand when, suddenly, people felt compelled to deny their mixed ancestry. And there were literally thousands and thousands of southern residents who shared this problem. So, I'd argue that Black Dutch was a "polite" euphemism for being "of mixed-ancestry" only if it were accepted by local—and military_-authorities; if not, going deeper into the upcountry South could be a family's only recourse. The mountainous region that would be named "Wise County" became one such safe 
destination, a sanctuary for those who needed more time to get "white-enough" according to these new racial categories. ${ }^{12}$

For some people it was necessary to find a way to explain their looks; they simply called themselves "Black Dutch" and hoped that was enough explanation to solve whatever problem, legal or personal, they were facing.

\section{THE WRITTEN RECORD}

Melungeons also share a formal history that can be verified by extant written records. Gallegos's citing of records in Spanish is especially interesting. One Relacion dated 1584 tells about a male Spaniard who, along with his wife and daughter, survived an Indian attack on one of the settlements. ${ }^{13}$ Gallegos alleges, based on his reading of records, that a new "race" 14 came about from the mixture of Europeans and native Americans that began in the $16^{\text {th }}$ century and persists to the present because of the social patterns these people adopted and passed down:

The new race of Cherokee and Spanish, Catawba and Spanish, Creek and Spanish developed a subculture. As each successive generation passed, they married only within the subculture, and began to progressively function outside of the pure Indian world. Later when the Irish and English arrived on the scene in the mountains of Georgia, South Carolina, Tennessee, North Carolina and Virginia this mélange would also function outside of the English and later the American world as well. More than ninety Spaniards and Portuguese remained [from

\footnotetext{
${ }^{12}$ Darlene Wilson, “'Black Dutch'-A Polite Euphemism,” Appalachian Quarterly 3 (1998) revised at http://www.melungeons.org/dw dutch.htm. Accessed 17 August 1999. This website is no longer available. ${ }^{13}$ Eloy Gallegos, The Melungeons, 60.

${ }^{14}$ Gallegos seems unaware of the negative connotations of the term "race."
} 
Pardo's expedition] in the mountains of northern Georgia and northeastern South

Carolina a few miles from Tennessee and North Carolina. These ninety men

would have been sufficient to begin a new race of people. Thus the Melungeons. ${ }^{15}$

This sounds convincing and ratifies other accounts of the discovery of European settlements already in the Appalachians when the English arrived in the 1600s. On the other hand, the known genealogical record of particular Melungeon families such as that of Vardiman Collins laid out below, would disagree and posit that such families came not from northern Georgia and northeastern South Carolina but from Virginia via North Carolina and that the Indian component was Saponi or Pamunkey.

Books about Melungeons by several authors including Ball, Bible, Gallegos, and Kennedy tell the story of James Needham and Gabriel Arthur, possibly his indentured servant, who came to the Tennessee Valley in April 1673 along with eight Indians. The first print account of this story appears in Samuel Williams' Early Travels in the

\section{Tennessee Country:}

Eight days journey down this river, lives a white people which have long beards and whiskers and weares clothing, and on some of ye other rivers lives a hairy people. Not many yeares since ye Tomahittans sent twenty men laden with beavor to ye white people: they killed tenn of them and put ye other tenn in irons, two of which tenn escaped and one of them came with one of my men to my plantation. As ye will understand after a small time of rest one of my men returns with his horse, ye Appomatock Indian and twelve Tomahittans, eight men and foure women. One of these eight is hee which hath been a prisoner of ye white people. .

\footnotetext{
${ }^{15}$ Eloy Gallegos, The Melungeons, 60.
} 
.. ye prisoner relates that ye white people have a bell which is six foot over which they ring morning and evening and att that time a great number of people congregate together and talkes he knows not what. ${ }^{16}$

Writers comment particularly on the bell, which they speculate means that the settlement was Roman Catholic and the fact that the English person could not understand the language the people were speaking.

Another story that Melungeons tell about their early history dates to 1784 and now lives in print. It involves John Sevier, the famous Tennessean who organized the short-lived State of Franklin and later became Tennessee's governor. According to Phyllis Barr's M.A. thesis, “The Melungeons of Newman's Ridge,” Sevier encountered a colony in the area that became the Tennessee counties of Hancock and Rhea. Writes Barr, "They were supposed to be of Moorish descent being neither Indian nor Negro but having fine European features and claiming to be Portuguese. ${ }^{17}$ None of the researchers who refer to this incident, which was supposedly chronicled in a letter written by Sevier, has ever seen the document. Jack Goins recounts that one of his ancestors, Thomas Bledsoe, served in the Revolutionary Army and filed for a pension on 24 April $1834 .{ }^{18}$ From this document, it is clear that Bledsoe was an Indian scout from 1778 to 1783 except for the time he was stationed at Fort Blackmore near the Stony Creek Baptist Church. Goins says, "If John Sevier actually wrote a letter about his encounter with the Melungeons, Fort Blackmore would have been the most likely place for Sevier to meet the

\footnotetext{
${ }^{16}$ Samuel C. Williams, Early Travels in the Tennessee Country (Johnson City, TN: The Watauga Press, 1928), 28-29.

${ }^{17}$ Phyllis Barr, “The Melungeons of Newman's Ridge” (M.A. thesis, East Tennessee State University, 1965), 2.

${ }^{18}$ Jack Goins, Melungeons, 65.
} 
Melungeons, because Thomas Bledsoe named Col. John Sevier as one of his company commanders." 19

\section{THE STIGMA OF "F.P.C.”}

Their designation as "free persons of color" did give these early mixed-ancestry pioneers a place in the society of the young nation. Many in Melungeon families served in the Revolutionary War, especially at the Battle of King's Mountain in North Carolina. Many veterans went west and bought land with bounty money, traded for it, squatted on it, or acquired it by land grant. Until the 1830s, people with mixed ancestry enjoyed legal rights accorded the white population. In 1830 the U.S. Congress passed the Indian Removal Act. ${ }^{20}$ Following the Nat Turner slave rebellion in 1831, the Virginia House of Delegates passed a law threatening to enslave free mulattos if they did not leave the commonwealth. ${ }^{21}$ In 1834 Tennessee disfranchised all persons of color denying them suffrage, access to schools, and the right to testify against a white person in court. ${ }^{22}$ North Carolina passed a similar law in $1835 .^{23}$ Researcher Pat Elder claims that most Melungeons who were listed as "free-colored" in the 1830 census were designated "white" in 1840, so in her view the legal climate favored those with mixed heritage; however, there are stories of persecution passed down in Melungeon families that are impossible to ignore. In 1857 the Dred Scott decision further jeopardized free colored

\footnotetext{
${ }^{19}$ Jack Goins, Melungeons, 65.

${ }^{20}$ C. S. Everett, "Melungeon History and Myth," 369.

${ }_{21}^{21}$ C. S. Everett, "Melungeon History and Myth," 370.

22 "Sons and Daughters of the Legend," audiotape of a National Public Radio documentary compiled by Wayne Winkler, WETS-FM, Johnson City, TN.

${ }^{23}$ C. S. Everett, "Melungeon History and Myth," 370.
} 
persons; anyone classified other than "white" could potentially be enslaved. What follows is the story of one person who navigated this time period in the Appalachian region.

\section{ONE MAN'S FAMILY. . . AND FRIENDS}

Many in the Melungeon community can trace their ancestry to Vardiman (Vardemon) Collins, who is recognized by all researchers as one of the first so-called Melungeons to settle near Newman's Ridge in Hancock County. Vardiman Collins was born in 1764 in Grayson County, Virginia. He came to the valley that bears his name to take possession of a North Carolina land grant that was originally issued to John Wolf in $1790 .{ }^{24}$ Collins received a subsequent grant to Newman Ridge land ${ }^{25}$ from Tennessee in $1816 .{ }^{26}$ Written $^{2}$ records show that Vardiman Collins's forebears came from further east. His father, Samuel Collins, was born in 1732 in Louisa County, Virginia, and appears on the tax rolls in 1771 in Bontetourt County, Virginia, where taxes were not collected because this Samuel Collins was living on "Indian land." Can we take this to mean that Vardy Collins, son of Samuel Collins, was Indian?

The records do not call him "Indian": instead he was officially a "free person of color" or "free colored" and was so designated on the census of 1830. Subsequently, he was brought to court for illegal voting in Hawkins County, Tennessee, in 1846. His illegal act occurred on August 7, 1845. The case was settled a year later out of court by Vardy Collins' son-in-law because the 82-year old Collins was sick on the day appointed

\footnotetext{
24 Jack Goins, Melungeons, 55.

${ }^{25}$ The land in what is now Hancock County, Tennessee, belonged to different governmental jurisdictions at different times. Before Tennessee entered the Union in 1796, the land was a part of North Carolina, then briefly under the government of the State of Franklin (1784-88). Hancock County came into being in 1844, but was not really organized until 1846. Before that time the Vardy Valley was a part of Hawkins County. Lee County, Virginia, at the northeast end of the valley was formed by petition in 1792 .

26 Jack Goins, Melungeons, 55.
} 
for the trial and unable to appear. Notwithstanding his absence, the court record states that he was "[n]ot a free white man of the age of twenty-one, and being disqualified by the laws of this state on account of color ... knowingly and unlawfully did vote at an election then and there." ${ }^{27}$ Apparently Vardy Collins was not one of those whose classification was changed in 1840. Vardy Collins's name also appears in court records as a witness in the trial of Levi Collins who was tried for larceny on 26 July $1838 .{ }^{28}$ It is not apparent in the court record whether Levi Collins was "free colored" or not, so it is impossible to tell whether the restriction on people of color testifying against white persons was being enforced.

Another example from this time period is one of Vardy Collins's neighbors, Charles Gibson of Newman Ridge, who filed for his Revolutionary War pension at Rogersville, the county seat of Hawkins County, on 19 January $1839 .{ }^{29}$ He gave his place of birth as Louisa County, Virginia, and claimed to be 92 years old. However, tax records from Orange County, North Carolina, put his age over 100 by 1839. Both Gibson and Collins owned land and were regularly paying taxes. It is difficult to know how they were perceived by their white neighbors.

\section{THE WRATH OF DR. PLECKER}

A horrible chapter in the history the Melungeon people share is related to Walter Plecker, a medical doctor who served as Virginia's first Registrar of Vital Statistics from 1912 to 1946. According to this man, there were only two categories of human beings — white and colored. For Plecker the Melungeons fell into the "colored" category. He worked

\footnotetext{
27 Jack Goins, Melungeons, 42.

${ }^{28}$ Jack Goins, Melungeons, 51.

29 Jack Goins, Melungeons, 51.
} 
through physicians, midwives, and petty bureaucrats to determine whom he would target in his racial purity campaign. In the name of the Virginia Racial Integrity Law, he would attach a document to the back of birth, death, and marriage certificates of persons he found to be colored according to his definition. The attachment would state that neither the person nor any descendants of the person could ever be considered white. Plecker also issued lists of proscribed surnames. Some of the people rose up and took matters into their own hands, "in Wise County, Virginia, an estimated $60 \%$ of all original marriage certificates are now 'missing,' either destroyed by friendly clerks or stolen by family members. $" 30$

In a letter to the Tennessee state librarian and archivist, Mrs. John Trotman Moore, on 20 August 1942, Plecker wrote,

[Melungeons] are now causing trouble in Virginia by their claims of Indian descent, with the privilege of intermarrying into the white race ... we have found ... that none of our Virginia people now claiming to be Indian are free from Negro admixture, and they are, therefore, according to our laws, classified as colored. In that class we include the Melungeons of Tennessee. ${ }^{31}$

In Lee County, the same county where several early Melungeon settlers signed the petition for the county's formation, J.P. Kelly, the Trustee of Schools in Pennington Gap received a letter from Plecker on 5 August 1930. The text of this letter, due to its insidious nature, deserves to be reproduced in its entirety below.

Our office has had a great deal of trouble in reference to the persistence of a group of people living in that section known as "Melungeons," whose families

\footnotetext{
30 "The Plecker Folder" Archive for A Melungeon Homepage, http://www.melungeons.org/archive.htm Accessed 6 June 1999. This website is no longer available.

${ }^{31}$ W.A. Plecker, Letter to Helen Trotwood Moore, 20 August 1942.
} 
came from Newman's Ridge, Tennessee. They are evidently of Negro origin and are so recognized in Tennessee, but when they have come over into Virginia they have been trying to pass as white. In a few instances we learn that they have married a low type of white people which increases the problem.

We understand that some of these negroes attempted to send their children to the Pennington Gap white school and that they were turned out by the School Board. Will you please give us a statement as to the names of the children that were thus refused admittance into the white schools and the names and addresses of their parents. If possible, we desire the full name of the father and the maiden name of the mother.

As these families originated out of Virginia, our old birth, death, and marriage records covering the period, 1853 through 1896, do not have them listed by color as are those whose families have lived in Virginia for a number of generations. They are demanding of us that we register them as white, which we persistently refuse to do. If we can get a statement that the School Board refused them admittance into the white schools, we can use that as one of the grounds upon which we would refuse to classify them as white. That, of course, is a matter of history and does not involve any individual but the whole School Board, the responsibility thus being divided up, while few individuals who write to us as to their Negro characteristics are willing to have their names used or to appear in court should it become necessary. This makes it very difficult for us to secure necessary information to properly classify them in our office. If the School Trustees will co-operate with our office and will refuse them admittance into the 
white schools and give us information when such refusals are made, we can without real difficulty hold them in their place, but this co-operation is very essential. $^{32}$

After reading this letter it is easy to understand why Melungeon descendants hate Plecker, a consummate racist and detestable government functionary. His policies made life more than difficult for Melungeons who lived in Virginia. His insistence during the first half of the $20^{\text {th }}$ century that Melungeon children attend schools for black children, robbed many Melungeon children of education. Their parents would not send them to black schools; the parents thought no school was a better alternative. Most families farmed anyway, and extra pairs of hands were more valuable than book-learning.

One example of the personal havoc Plecker's eugenics, or doctrines of "racial integrity," wrought was narrated on the Melungeon email list. A female adolescent, relative of the list participant, went into a Wise County hospital in the 1940s to have her appendix removed and was treated as well to a complete hysterectomy. The surgeon claimed afterward that he made a mistake. The horrors of the Plecker years are seared into the consciousness of Melungeon descendants - a part of their lived reality.

In Virginia the laws were against them and so were local customs. In an autobiographical narrative that originally appeared in Under One Sky, Darlene Wilson recounts her experiences as a teenager in Southwest Virginia:

[W]hen I was 16 yrs old (summer of '69), I took a part-time summer job at Doc Durden's lunch counter/store (remember that, anybody?) on Park Avenue in Norton. Around the first of August, the proprietor and his wife . . began going

\footnotetext{
${ }^{32}$ W. A. Plecker, Letter to J.P. Kelly, 5 August 1930.
} 
over the store and carefully securing everything, removing counter displays, locking up the lipsticks and jewelry, keeping the back door (to the alley) locked up every day instead of open for the convenience of workers in buildings behind Park Avenue.

When I asked why they were doing all that, a regular employee told me that August was the unofficial, but widely recognized, annual "Melungeon time" for merchants in Norton. I probably looked dumb-struck since she went on to explain about all these "rogues" and thieves and their in-bred kin-folks who came down once a year from Stone Mountain to shop (and steal) in Norton; she added: “of course, you know, they're really FROM over in Scott and Lee counties."

The next day, I got my first look at these "Melungeons" when the same employee grabbed my arm and pointed to the door, saying, "See- - here they come!" I looked and saw what appeared to be customers like many others who came in day-after-day: regular-looking people, a family perhaps, their clothes were clean but not "high(ly)-styled," some (but not all) had dark brown or black hair, sharp, swarthy features and dark brows, and a propensity to shyness when approached by sales clerks or waitresses.

The point is - they looked and acted just like me and many members of my extended family. The differences were few-they weren't dressed-up, in the sense of "going out-on-the-town" and tended to be dressed too warmly for August weather. But then, as I learned when I "waited" on them, they had been traveling since before day-break, bringing their ginseng and other trade-goods to market. Hence the splurge of shopping, "the Melungeon time" for the merchants. The 
women and children were prone to touching merchandise - pretty silky fabrics or smell-good-stuff-but then so was I, though my mother would occasionally slap my hand and say, “you don't know who else's been handling that!"

Later on the first M-day, I asked Mrs. Durden . . . how much merchandise she thought they'd lost to these Melungeons over the many years that they'd been in Norton. She couldn't remember that they'd lost anything because they'd been warned on their arrival by other merchants to "lock it all up" when the Melungeons came to town and to make sure they didn't "touch" anything that couldn't be cleaned of their taint.

Then she told me to get some disinfectant and start washing down the booths where several such Melungeon families had just finished eating. Since it was still the middle of the busy afternoon-hours, I must have objected because I remember that she almost hissed at me- "Do it now! Those folks are nasty and nice people might have to handle what they just touched!",33

I read this story when I was doing the research for How They Shine, and I never forgot it. It seemed so ugly and so sad. Yet, this story really happened and not so very long ago; I do not doubt its veracity. Being on the receiving end of such hateful attitudes and discriminatory acts could render a designation of "white" on the census irrelevant. The prejudice was real, and it was based on skin color, family name, and social class. At the end of this same piece, Wilson writes about the fact and the effects of racial prejudice in Appalachia:

\footnotetext{
${ }^{33}$ Darlene Wilson, "Race, Face, and Place: On Becoming Color-Minded," Under One Sky, April 1997, found at http://www.melungeons.org/mel_uos2.htm . This website is no longer available.
} 
Someone recently told me of an elderly man from Wise County who said that Melungeon had been a "fighting word" when he was young and he couldn't understand that now anyone would want to be one. I think he was expressing the sentiments of many for whom Melungeon and "ramp" still mean "dirty" and “low-class.” Let me put it like this: you can't have an Appalachian (or American) "white middle-class" unless a mostly-white, or trying-to-be-white, under-class is also available for the middle-class to point to and say, "See the no-class, see the Melungeon, see the filth—well, that's not me or my people!"34

Those of us who see Melungeon people and the scenarios that are their lives as research topics run the risk of trivializing their experience. Stories like this one that Darlene Wilson tells and the one from the Melungeon email list about the girl who went to surgery for an appendectomy and had a hysterectomy as well ground us in painful reality and are unforgettable.

\section{MELUNGEON FOLKLORE?}

Even though scholars for whom folklore is a discipline insist that Melungeons do not have any, there are tales that persist in the fiction featuring Melungeon characters and in non-fiction books and articles. Scholars Saundra Keyes Ivey and Melanie Sovine both explore the question of where the stories come from.

Sovine alleges in her 1982 doctoral dissertation that stories Melungeon descendants tell as if they were tales passed down in an oral tradition are really stories that come from what she terms "the literature," by which she means articles written in the

\footnotetext{
${ }^{34}$ Darlene Wilson, "Race, Face, Place.”
} 
popular press as early as 1849 . Sovine claims that newspaper and magazine articles are “ideologically biased," and based on three false assumptions: (1) Melungeons are of indeterminate origin; (2) there is such a thing as a collective Melungeon identity; and (3) Melungeon population is centered on Newman's Ridge in Hancock County. She asserts that "the literature offers a mythical image that is rarely congruent with the empirical reality corresponding to the people who are labeled 'Melungeon.", 35 Her complaint is that popular writers tend to reference other popular writers and so perpetuate the "myth." In her judgment not even academic research is effecting a change in this situation.

In my judgment, Saundra Ivey, whose 1976 dissertation was called “Oral, Printed, and Popular Culture Traditions Related to the Melungeons of Hancock County, Tennessee," ${ }^{36}$ wishes that the narratives people told here were authentic folklore, but she doubts they are. Her doubts spring from both ideas and phrases that cropped up repeatedly in her informants' versions of the events and stories that she alleges can be traced back to particular written accounts of life on Newman's Ridge. Ivey spent months in Hancock County collecting data and even worked as part of the production crew for the Melungeon outdoor drama Walk Toward the Sunset in the early 1970s. Her dissertation is full of Melungeon stories.

One story that surfaces over and over-in the talk of Ivey's informants, in the Tennessee Writers'

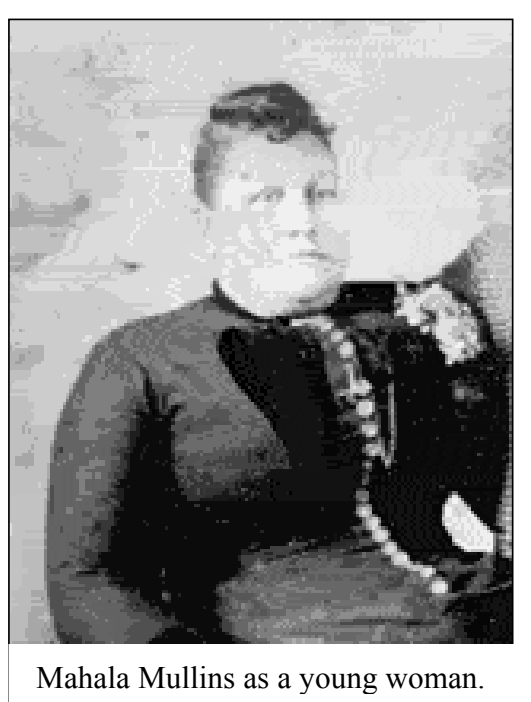

\footnotetext{
${ }^{35}$ Melanie L. Sovine, "The Mysterious Melungeons: A Critique of the Mythical Image" (Ph.D. diss., University of Kentucky, 1982), 2.

${ }^{36}$ Saundra Keyes Ivey, "Oral, Printed and Popular Culture Traditions Related to the Melungeons of Hanock County, Tennessee," (Ph.D. diss. Indiana University, 1976).
} 
Project's Melungeon Tales, in book-length treatments of the Melungeons like Kennedy's or Bible's, in the fiction, in the popular press - is the one about the most famous Melungeon of them all, Mahala Collins Mullins. Aunt Mahaley was a real person, born in 1824 in the Vardy community. Her parents were Solomon Collins, one of the earliest settlers of the region, and Gincie Goins. Solomon Collins, thought to be Indian, was numbered in the census in Lee County, Virginia, in 1810 and is known to have received several Tennessee land grants-Claiborne County in 1829, Hawkins County in 1833 and 1845. ${ }^{37}$ His daughter Mahala married John (Skinny) Mullins and had 20 children, 15 of whom lived to adulthood. Mahala and Johnny lived on Newman's Ridge in a log house that was large by mountain standards; it had two good-sized rooms with a dogtrot between, a long front porch, and boasted an upstairs room over the entire length of the structure. This house had arched windows, a sign by taken by some to indicate Portuguese heritage.

According to R.C. Mullins, his family was the last to live in the house (shown at right before it was moved off Newman's Ridge in 1999). When Mullins was growing up in the 1940 s and $50 \mathrm{~s}$, there were orchards on the hillsides around the house that yielded the best tasting apples in the

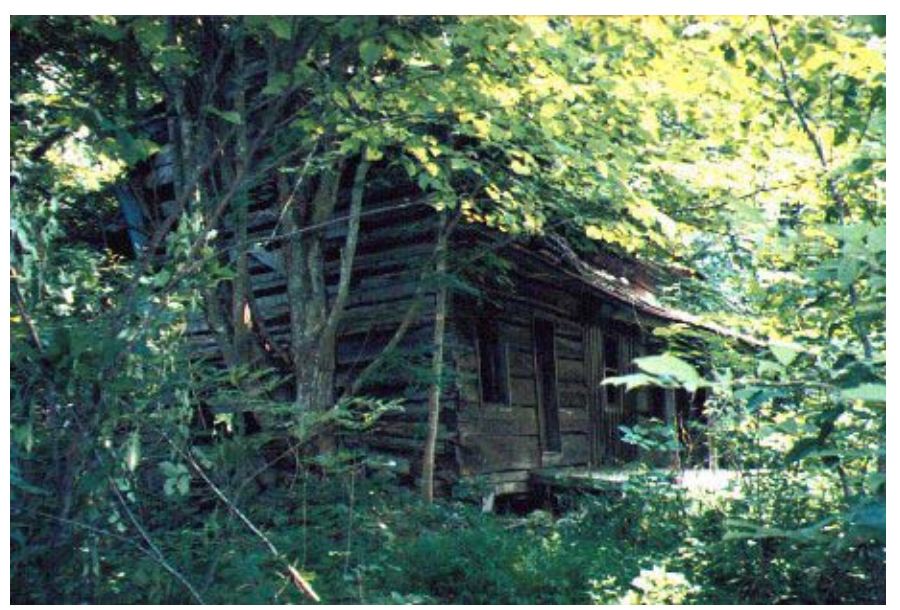

This snapshot shows the Mahala Mullins cabin in decay on Newman's Ridge. It now stands restored across from the Vardy Presbyterian Church and is part of the Museum complex of the Vardy Community Historical Society.

\footnotetext{
${ }^{37}$ Again the timing of these grants is important. Claiborne County is just west of present day Hancock County, and Hancock County was formed from part of Hawkins County in 1844, but didn't function as a governmental entity until 1846 .
} 
community. Aunt Mahaley, was known for two things: her size —-she was reputed in some versions of her the stories told about her including James Aswell's "Six Hundred Honest Pounds" to weigh 600 — and the quality of her moonshine. Several anecdotes are told and re-told about this woman who is depicted by Jesse Stuart in Daughter of the Legend as Sylvania.

The most often repeated story about Aunt Mahala features her in her role as exemplary moonshiner for the region in the days after the manufacturing of corn liquor became illegal. A young deputy, determined to succeed at his new job, decided to find the site of Mahala's operation, shut it down, and bring her to jail. The sheriff, older and wiser, smiled and told his deputy where to find Mahala's cabin. The young deputy found her, but couldn't arrest her because she was too big to fit through the cabin door. He poured out her existing supply but had no more success than his predecessors-except that he's remembered for his report to the sheriff, "She's ketchable, but she ain't fetchable!"38

The narrative of Mahala's funeral is another familiar story. One popular version states that a chimney at one end of the room was dismantled so that her coffin, boards nailed around her enormous bed, could be removed from the house. It could no more fit through the door than she could. Saundra Ivey felt that the chimney story was untrue. Instead, some of her informants who were relatives insisted that there was no chimney, only an opening in the cabin wall where a chimney might go that had been boarded over. The boards were simply taken down to allow for the removal of the coffin.

\footnotetext{
${ }^{38}$ This version of the story is paraphrased from Katie Hoffman Doman “She's Ketchable, but She Ain't Fetchable," Appalachian Life Magazine, April-May 2001, 26. Jim Callahan's version of the story is slightly different. In his story Sheriff Wash Eads is the one who serves Mahala with a warrant for her arrest and writes the memorable quote on the back.
} 
Some of the most interesting insights about Mahala Mullins come from her descendant James Callahan in his recent book Lest We Forget. Callahan's recounting of the family stories reveals a darker truth about this Melungeon icon than the "folk" tales tell. Callahan is the great-grandson of Calvin Mullins, born in 1860, youngest of Mahala and Johnnie's children. By 1895, Mahala had been too large to get through the door of her cabin for some years due to elephantiasis; according to family accounts, she would sit at the window of the cabin waiting for customers, as neither the proscription of the law nor frequent fines deterred the family from making and selling 'shine. The following anecdote is stark and brutal.

Near the end of Mahala's life, her boys were drinking heavily and they argued over a woman. We know that brother Elby was home, along with Calvin (my great-grandfather), mother Mahala, and her nephew Willie Davidson, son of Gib and Sally Mullins Davidson. Calvin was a heavy drinker and was upset over possible infidelity between his wife "Coose" and his nephew Willie Davidson. Willie was lame in one leg and always hopped, in lieu of using crutches or a cane. He was obviously not a physical match for Calvin. Calvin accused Willie of having an affair with his wife and chased him out the rear door with a shotgun. The chase was brief, as Willie hopped and had little hope of fleeing the onslaught of the swifter Calvin. Calvin caught him with the butt of his shotgun to the side of his head with such force as to knock his eye out of the socket. Willie went down, temporarily blinded in one eye and partially conscious. Calvin leaped on for the kill and commenced to strangle the remaining life from the breathless Willie. 
Willie was just conscious enough to draw his .38 and discharge it into the chest area of his adversary.

Stories say Mahala watched the event, noticed their abandoned drinks, and commented after the tragedy, "I can't let this good shine go to waste, I'll just drink it myself." Calvin lay dead, and Willie survived to stand trial and be acquitted. The judgment was that he had acted in self-defense. Secondly, he was judged a cripple and credits were given for him being at a disadvantage. ${ }^{39}$

This story makes the Dromgoole articles seem tame. Yet Callahan took me to task in a public presentation because I said his book seemed a "dark" depiction of life on Newman's Ridge.

Callahan did not know he was kin to the legendary Vardy resident until he was an adult because his grandmother, Hattie Mullins Bales, left Tennessee in 1931 for Indiana and never returned. Callahan at one point read an article about Melungeons that was illustrated by the familiar photograph of Mahala shown at right. He recognized that picture as one that sat on his grandmother's bureau. Only then did he start asking questions about his heritage and doing research to find out as much as he could. His portrait of Mahala's last days, based on his conversations with family members and quoted below, is

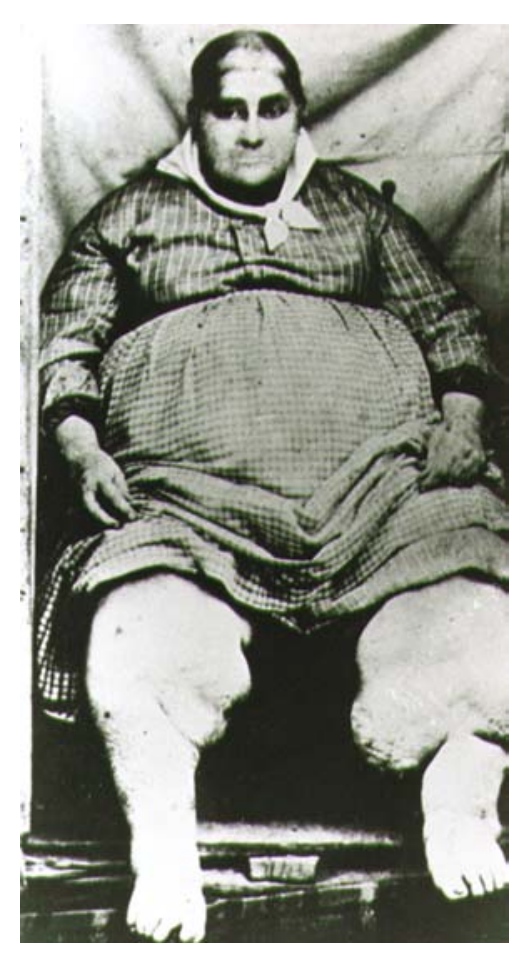

Mahala as an old woman when she was suffering from elephantiasis.

\footnotetext{
${ }^{39}$ Jim Callahan, Lest We Forget, (Johnson City, TN: Overmountain Press, 2000, 186.
} 
grim:

This period ends with Mahala infirmed and old with the ravages of elephantiasis. She has lost Johnnie. ... She still sat in the big chair by the kitchen window waiting for customers to taste her brew, but as she peered out and thought of the sorrows, of the violent and tragic losses of Burton, Richard, Ollie, and Calvin, life did not seem good. . . . Her granddaughter Hattie [Calvin's daughter, Callahan's grandmother], abandoned by her mother [Coose] after her father's tragic death, spent most of her time tending to her grandmother. With assistance, Hattie religiously helped lift her onto the galvanized tub with $4 \times 4$ cross members for bathroom activities. Hattie remembered her during this time as still patient and gentle, but a reflective grandmother. ... As she had never professed a faith in Christianity, she had little spiritual hope to sustain her... .

Mahala died on September 10, 1898. . . Colony members walked or rode horses back for miles to congregate, drink "shine," and mourn her passing. A large number of pallbearers carried her huge diseased body (probably 500-600 pounds) to the family site to join Johnnie, Ollie, Calvin, Millie, Coffee, and other members of the clan. ${ }^{40}$

This picture is somber, not light-hearted like the fictional accounts' depictions of Mahala_James Aswell's in “Six Hundred Honest Pounds” or Jesse Stuart's in Daughter of the Legend. Mahala in Callahan's narrative is pathetic, not tragic.

Another folklore/fakelore story that comes up time and again concerns the "lost" Swift silver mines. Some think that somewhere along the way, talented metal workers

\footnotetext{
${ }^{40} \mathrm{Jim}$ Callahan, Lest We Forget, 203-05.
} 
were among Melungeon forebears and that these craftsmen found silver and even gold somewhere in Appalachia. One source for this story is a book called History of Tennessee and the Tennesseans by Hale and Merritt:

From time immemorial they have been counterfeiters of gold and silver, and strange to say, their money contained more of the precious metals per coin than that minted by the government. At one time during my recollections these coins passed without question. There is a legend that their silver came from Straight Creek, a tributary of the Cumberland River, which flows into that stream at Cumberland Ford (now Pineville, Kentucky). Ruins of ancient furnaces are still to be seen along the banks of Straight Creek, but have not been used within the memory of anyone living. A family named Mullins were the makers of the silver money in that section. The Beckler gold dollars were coined in North Carolina, and some of these coins are yet extant, preserved as curiosities. They were of native gold made by a family named Beckler, and were called "Becklers."41 Brent Kennedy refers to this metalworking legend by tying it to the person he calls "the third most famous" Melungeons, his ancestors "Brandy Jack" Mullins and Jack’s uncle “Counterfeitin' Sol” Mullins. ${ }^{42}$ Kennedy does allow that at least Brandy Jack served time for his shenanigans. The story of counterfeiting among the Melungeons also surfaces in the oral history volume about Grundy, Virginia, edited by Appalachian novelist Lee Smith. In the section about Dot Dellinger is this story:

My granddaddy is the one that made the silver dollars. I ought to tell you about that. You know where Willowbrook Country club is, don't you? That is where

\footnotetext{
${ }^{41}$ W.T. Hale and Dixon L. Merritt, History of Tennessee and the Tennesseeans (Chicago and New York: Lewis Publishing Company, 1913), Vol. I, 180-81.

${ }^{42}$ Brent Kennedy, The Melungeons, 19.
} 
they lived, and where my mama grew up, over there on Grassy Creek at the Breaks. Once it was an Indian town. The Indians put all their belongings in the grave there on the Mullins estate. Many flints and pieces of tomahawks have been found there. My great-grandfather "Dr. Jim" Mullins, who lived there, was an herb doctor. I have an aunt buried in the "white" Golf Course Cemetery, and my grandfather's slaves were buried in the "black" Golf Course Cemetery. My grandfather, Noah Mullins, told stories about Indian legends and the Civil War. When the soldiers passed through the Breaks, the people buried their money in the ground to keep it safe. My grandfather and his brother Enoch made fifty-cent pieces from steel molds. They would take Mexican silver dollars and mix steel, zinc, and other metals with it. They could make several fifty-cent pieces from one Mexican dollar. The government finally caught them, but they were never punished for it. These dies and molds are buried somewhere on the Mullins estate, to this day. The Mullins family still owns some of the old pieces of counterfeit they made. $^{43}$

This version is a slightly different take on the events, but the name Mullins and the tales of counterfeiting in the long-ago echo the story related in the Hale and Merritt narrative and picked up in so many others. Melungeons share knowledge of and allegiance to both the Mahala stories and the legends of rich Melungeon counterfeitors. In both cases there is real satisfaction because the law is circumvented and white officials made to look incompetent. The Melungeons win.

\footnotetext{
${ }^{43}$ Lee Smith, ed. Sitting on the Courthouse Bench: An Oral History of Grundy, Virginia Chapel Hill, NC: Tryon Publishing, 2000), 180-81).
} 
Another facet of folklore is how it chronicles the customs of a group of people. Herbal medicine traditions are often included under the folklore rubric. The mention of the Mullins herb doctor in Dot Dellinger's oral history narrative brings up another persistent refrain. Many mountain people used herbs as medicines, but tradition has it that the Melungeons had no other medical option but herbs because no doctor would treat them. Not only did they live far up in the hills, but their status, or lack of it, meant that no physician would be associated with them. They learned about and used the herbs, which were often mediated to patients by "granny women" who were midwives as well as healers, because there was no alternative. In Jesse Stuart's Daughter of the Legend the heroine dies in childbirth for lack of good medical care. My chapter in this dissertation about the email communication among Melungeon descendants is focused on a discussion thread called "Melungeon herbal medicines." There is more about this topic yet to come.

\section{THE REAL LEGACY OF THE WAR BETWEEN THE STATES}

The Civil War as it was fought and endured in the mountain South was very different from the version of the war most Americans are familiar with. Again, there are stories that do not appear in the history texts school children study. Melungeons fought on both sides; some individuals fought first on one side and later on the other. Some Melungeons fought on neither side, but instead used the war as an excuse to wreak havoc on their persecutors. The war as it was in the mountains is part of the shared experience of those who call themselves Melungeon. Times were hard for all mountain families 
+ but especially hard for Melungeons. Some of the most violent episodes in the history of Melungeon settlements occurred during the war or shortly thereafter. Loyalties of mountaineers were divided; slave holding was the exception rather than the rule, so many in Appalachia supported the Union and served in the Federal Army. Harry Caudill in Night Comes to the Cumberlands explains clearly how it was:

$[T]$ he great majority of the highlanders were, from the outset, sympathetic with the Union. ... [T] $]$ hese were not men, who, in the modern sense, had to be trained and inured to the privations and bloodletting of warfare. They had known the discomforts of cold and heat, and sometimes of hunger and thirst, since boyhood. They could walk tirelessly for many miles and the use of the rifle came almost by instinct to their hands and eyes. ... [T] o their soldierly virtues was added a grave defect — an unrelenting hatred of discipline and order. The highland soldier wore the collar of military discipline with poor grace, frequently deserting when an officer "got too big for his britches.". . From every valley went forth Confederate and Union men. Cousins took opposite sides, and sometimes brother and even fathers and sons split on the issue. Such partings in the early stages of the war were relatively friendly, but it could not remain so for long. As the months passed wounded and crippled men began to return, and they brought reports of the deaths of others. When the occupants of a mountain cabin learned that a son, brother or father had died at the hands of Union or Rebel troops on some distant battlefield, they fixed their resentment, not against the far-off armies but against the known and near neighbors, relatives of former friends who had put on the uniform of the 
army at whose hands the loved one had perished. . . They were quick to anger and quick to carry that anger into effective action."

Bands of angry men would sweep down on a farm or homeplace, take tools, foodstuffs, and livestock, kill the men, burn the barn, and sometimes rape the women. It was a scary time. Jack Goins writes about several of his ancestors who were killed in a bloody raid on their home:

Most of the sons of Zachariah Minor and Isaiah Goins first enlisted with the Confederates at War Gap they later joined the Union. ... Fishers Valley was a violent place during the Civil War: several died leaving many broken homes. The violence that occurred in this area left a terrible remembrance for the families that survived. The author lost two great, great grandparents, Samuel Arrington Co. E First Tennessee Calvary, ... and William Goins who along with four other men were hung by rebels in January 1865 . They were hung at a spring back in a hollow near their home by marauding Rebel Soldiers. . .

Three of these hung were brother-in-laws married to daughters of Zachariah and Aggy Sizemore Minor, and lived within two miles of each other. . . In 1937 Hezekiah Goins, son of William Goins, described the night of his father's death to his grandson Hustler Lee Goins. "He was guarding the house while his dad was eating supper, when a group of men with grey uniforms approached. He went in the house and told his father. Then dad runs out the back door but was captured and taken away. They hung him near Rebel Spring.”. .

\footnotetext{
${ }^{44}$ Harry M. Caudill, Night Comes to the Cumberlands: A Biography of a Depressed Area. (Boston: Little, Brown, and Company, 1962, 1963), 38-40.
} 
The reason for this hanging near the end of the civil War will probably never be known. We do know by military records that most of these men first joined the Confederate Army then left and joined the Federal Army. ${ }^{45}$

One result of this multiple hanging was the cause of further violence in Hancock and Hawkins Counties perpetrated by the Sizemore gang. William Sizemore, "Bill," was operating as the leader of a band of "federalist guerillas" and after the war was known as a sort of "desperado." 46 According to local lore as reported in the Knoxville Journal, Sizemore would shoot people who looked askance at him, and he was reputed to have killed 15 people. According to Goins, Sizemore's relatives claimed, “after rebel soldiers killed his brother Christopher, Bill vowed to kill a rebel soldier for ever hair on Kit's head. ${ }^{, 47}$ Family members say that in spite of his desire for revenge, Bill did not carry a gun after the war. He was, however, killed in a shootout by a man named Iredell Willis carrying a war-related grudge (Bill had apparently taken his bayonet, cut a large X on Iredell's grandmother's back and rubbed salt in the wound because he thought she was lying and not giving him information he wanted):

This meeting took place at a saloon in Rogersville which was located in front of the Court House. Iredell told Bill he was going to kill him, Bill replied that he had not carried a gun since the war ended. Iredell then pulled two large pistols out from under his coat and placed them on the bar and told Bill to choose one. They both proceeded to the front lawn and stood back to back, walked 15 paces, turned and Bill Sizemore was killed. ${ }^{48}$

\footnotetext{
45 Jack Goins, Melungeons, 104-07.

${ }^{46}$ Unsigned article from the Knoxville Journal, 30 January 1892, quoted in Jack Goins' book, 21-25.

47 Jack Goins, Melungeons, 107.

48 Jack Goins, Melungeons, 28.
} 
This story and others like it are part of the literacy of the Melungeon-ness for descendants in Hancock County. Present-day animosities sometimes harken back to an incident that occurred well over a hundred years ago. Grudges die hard.

In his book, Jim Callahan tells a family story about a Confederate raid in Vardy. The Mahala Mullins cabin as it existed on Newman's Ridge for many years, and as it now stands (having been recently dismantled and moved off the ridge to the valley where it now sits opposite the Vardy Church Museum) is actually a rebuilt version of Mahala and John Mullins' original home. Callahan writes,

The house was rebuilt after being burned by Confederate raiders. This house and the first home were frequent stopovers for buyers of illicit liquor made by the Mullins family. Bartering was common, and Mahala and family seemed to have a large inventory of material goods accepted for liquor. Guns, skillets, pots, knives, ammunition and other items were in abundance at the home. So, during the Civil War, raids were frequent in the area of Mahala's house. The confederates were only one mile down Vardy Valley in Lee County, Virginia, and always knew of the potential for supplies at Mahala's.

One story tells of the Confederate raiders coming to loot and kill the Mullins boys and their kin home from the Union Army. . . The Rebs advanced, but their adversaries escaped down the ravine by the spring. . . .

The raiders set the house on fire after looting and departed. The family hurriedly worked the conveyor bucket connected to the spring to extinguish the fire and restore order. Some of the children were still very young. Calvin, the last born and my great-grandfather, was an infant. No sooner had the fire been 
extinguished, than the raiders returned and ordered all outside into the light skiff of snow. The children were barefooted. Calvin was carried by sister Mary Ann on her hip, as she was a small girl. This time the Confederates torched the house and waited with the family to watch it burn beyond salvaging before departure. ${ }^{49}$ Men loyal to both sides perpetrated these atrocities; the war was no respecter of persons, possessions, or protestations of loyalty. Mountain families, Melungeon or not, could expect no protection from either army. The generals were concerned with the "real" war on bigger battlefields, not with the foraging and bushwhacking that ravaged the mountain counties.

\section{THREE IMPORTANT THEMES}

The Mahala stories in their multiple versions are a very visible piece of Melungeon lore and a shared experience for Melungeon descendants. These stories also illustrate three themes that are woven through the lives of many and through the stories they tell. These themes — violence, alcohol abuse, and sexual infidelity—emerge in postings to the email lists, in fiction incorporating Melungeon characters, in several interviews I have done, and in casual conversations. While these tendencies are certainly not unique to families of Melungeon descent, they are definitely negatives as they apply to these families and important components of their shared experience, part of what it means to be Melungeon.

Violence, at the core of the Civil War stories, did not end in Melungeon communities at the turn of the $20^{\text {th }}$ century. When I was in Vardy doing interviews in

\footnotetext{
${ }^{49}$ Jim Callahan, Lest We Forget, 196-97.
} 
May 2003, one informant told me that a house had been deliberately torched, and furthermore that arson had occurred so often in the valley that home owner's insurance for houses there is exorbitantly high. Another informant, when talking about his family, told that his older brother had been shot and killed by his girlfriend in a domestic dispute. A third story was about one man beating another almost to death because of a remark taken as a slight about the first man's wife.

A second prevalent theme both in the Mahala stories and in other stories both on the email list and in the narratives of my informants is the abuse of alcohol. It is not surprising that a region known for the manufacture of whiskey would be plagued by alcohol abuse. References to families torn apart by drunkenness are not uncommon on the Melungeon-L email list. One of my informants told me that his father had been a bootlegger, and, because of that, the family had cash to spend that other families didn't have. Nonetheless, he saw alcohol abuse as a major problem in Hancock County. He said he didn't know whether it was Indian blood or not, but, whatever the cause, weakness for alcohol had always been a serious problem. "So many men just drank themselves to death; they didn't live to be 50 . Alcohol has always been the drug of choice in this area." Initially whiskey as a commodity was a boon, easier to get to market over the mountain tracks than corn and worth a good deal more in cash. However, the making of moonshine became a way of life that was clearly detrimental. Others have acknowledged this problem in print:

Eventually, vast amounts of liquor to produce, to hold on inventory, and to sell contributed to their own decline. The daily temptation was too readily available to ease their misery. This seems to be an all-encompassing statement, as not all 
Melungeons were participants in the business of illegal liquor, but the activity was so rampant within the colony that it had a detrimental effect on the very soul of their culture. . . Moonshine extended their longevity in the hills, but captured their souls as they succumbed to the temptations it offered. ${ }^{50}$

The third problem alluded to the Mahala stories is that of marital infidelity. This problem is not confined to the $19^{\text {th }}$ century stories. One of my informants talked openly about his father, who had two "families" - one with his wife and another with a girlfriend. In fact, his father died of a heart attack with his girlfriend, not at home. "That's just the way it was," he told me, "and I think it really hurt my mom. Even after my dad died she had a hard time trusting [her second husband]. She just couldn't believe that men could be trusted." He then went on to tell me about another person known to me from my times in Vardy who has had "two beautiful wives, and each time a beautiful girlfriend." Apparently, this practice was common in spite of the anguish it surely causes.

These three then, taken for granted and freely discussed, constitute shared experience for my informants and others in the Melungeon community.

\section{TWO DIFFERENT DEPICTIONS: OUTSIDER AND INSIDER}

Southern Appalachia is a distinct discourse community. A sharp listener can hear the vernacular occasionally in the towns like Bristol or Norton or Hazard, but genuine mountain dialect flourishes in the hills, hollers, and hamlets of the region. The two writers whose work appears below deal with the language in different ways.

\footnotetext{
${ }^{50}$ Jim Callahan, Lest We Forget, 182 \& 206.
} 
Author Bonnie Ball grew up the daughter of a farmer in Lee County, Virginia, and came into contact with Melungeon people all her life, especially in her role as an elementary teacher. Her book seems dated when set aside Kennedy's or even Callahan's. Yet her observations are authentic and reveal the perspective of an honest seeker after the truth about a group that stood out from the rest of society in Lee County in the middle of the $20^{\text {th }}$ century. Pertinent excerpts from The Melungeons: Notes on the Origin of a Race follow.

I have known Melungeons since early childhood, when they came from coal towns in adjoining counties to clear land and sharecrop on my father's farm in Lee County, Virginia. Their children attended our public schools, and in later years some of them were my pupils.

My parents knew older Melungeons who lived on Newman's Ridge, along the Virginia-Tennessee border. Their skin was dark and oily, showing more of a coppery color than of, say, Ethiopians or darker members of the white race. Their hair was often coarse and black, and in some families extremely kinked. Others were little different from their white neighbors, with brown or black wavy hair, gray or blue eyes, and rather high cheekbones. I even recall another type among the Melungeons: those with dark slightly curly hair, smooth dark skin, and dreamy eyes that seemed almost Oriental. ${ }^{51}$

In her research Ball was given notes on an interview with an old man from the Dungannon area of Scott County named "Uncle Washington Osborne." This old man

\footnotetext{
${ }^{51}$ Bonnie Ball, The Melungeons: Notes on the Origin of a Race ( reprint, Johnson City, TN: Overmountain Press, 1992), v.
} 
referred to the Melungeons as "Melongo," which he defined as pure Portuguese.

According to Ball, the man said,

The Bollings, who are numerous in Scott County and Wise County, came from Newman's Ridge. They have all the features of the Indian race. Old Jack Bolling was the progenitor of the Scott county Bollings, and his people were strong, and spoke broken English. . . . Ethan Moore was one-third Portuguese Indian. Of course, the other two thirds consisted of Irish and I don't know what. Ethan Moore had tolerable dark skin, broad cheekbones, very pretty eyes as black as a cat's, a nose three inches long, very flat and wide as a possum's. . . The Minors are a fighting people and show more of the Indian than any other Indian group in Scott County. They claim to be of Portuguese-Indian stock. They are of large stature, tall, of dark complexion, and very strong. I believe the Minors are threequarters Indian and one-quarter Portuguese. They are the type of people whose word is their bond. In Scott County some of them own large stock farms and have prospered. $^{52}$

Ball's own observations tell as much about her and her presuppositions as they do about the Melungeons. Lee County, Virginia, where she grew up and later taught school includes Pennington Gap, the town that Walter Plecker was targeting in his antiMelungeon letter. Ball writes in the second half of the $20^{\text {th }}$ century after the schools were integrated and reflects the attitudes of her time. Conditions for people of color had improved, especially in terms of their access to education and to the voting booth, but her descriptions seem patronizing. In the excerpts below, she pulls together many of the ideas

\footnotetext{
${ }^{52}$ Bonnie Ball, The Melungeons, 76-78.
} 
she read about in her research with her own perceptions about the Melungeons she knew personally. She writes,

The present-day Melungeons are largely farmers or tenants, but some have been miners. Most of them are indifferent to schools, with a probable exception of the mission school at Vardy, Tennessee. . . . A few of them (or those with some Melungeon blood) have gone to church colleges, but there seems to be no record of any having graduated. . . Physical features of the Melungeons are indicative of much more than just an Indian-white mixture. While it is true that there are a few "traces" of black blood, there is even stronger evidence of an Old World background. . . . Their aversion to formal education and the conventional restrictions of the white race, their "closeness" to nature, their physical endurance, skill in boating, primitive modes of fishing and hunting, as well as their knowledge of herbs, are likely carryovers from their Indian ancestors. Their efficiency in herding and handling livestock may be "inherited" from the Moors. ${ }^{53}$ Different from Bonnie Ball's account is the gentle memoir of an insider, Mattie Ruth Johnson's My Melungeon Heritage. Johnson grew up on the south side of Newman's Ridge in Hancock County. She did not attend the Vardy School because it was too far to walk there from the farm she lived on. She can trace her ancestors back to "Irish" Jim Mullins and his wife Clara Martin on her father's side and Vardiman Collins and his wife "Spanish" Peggy Gibson as well as Solomon Collins and his wife Gincie Goins on her mother's. She can boast a true Melungeon heritage. Johnson left Hancock County for nearby Kingsport after her mother, Opal Mae Collins Johnson, died in

\footnotetext{
${ }^{53}$ Bonnie Ball, The Melungeons, 79 \& 97.
} 
childbirth with her eighth child at 37 . The farm they worked on Newman's Ridge was land her mother's family owned; the Collinses apparently would not agree to her father, Henry Johnson, staying on the land notwithstanding his seven children who were heirs. Mattie Ruth Johnson graduated from high school in Kingsport and went on to become a nurse. Her narrative is spontaneous and ingenuous, evoking another time and place.

I realize that the way of life that existed for me and my family on Newman's Ridge is gone. It is likely that our descendants will never work in the cornfields, pull tobacco, or see nature as we saw it. ... As small children we were told that we were related to the Melungeons, but we did not know what that really meant. ... Several of our ancestors were listed among the first settlers to the area and as "(FC)"... [which] probably came about because many Melungeons were dark-skinned. . . .

As children, my siblings and I had heard of the Melungeons. We had a local habit of calling each other some other person's name when we were mad about something. ... Once, we got to calling each other an old Melungeon; we would say, "You old Melungeon, you!" until Mom heard us and said that if she ever heard us talking like that again she would give us a whipping. She went on to say that Melungeons were good people who were kin to us and that we should never let that kind of talk come out of our mouths again.

Most of the people on Newman's Ridge were white or light brown, some having darker skin than others. They looked more like a white mixture with Indian, Spanish, Portuguese, or Mediterranean thrown in here and there. . . . Typically they were tall and slim, with high cheekbones and round faces. Those 
that were heavier got that way with age. . . There were those with thin lips and black hair; others with blond hair and blue eyes; still others with dark hair and blue eyes. . . .

Two of my fourth great-grandfathers . . . Old Solomon Collins and Vardemon Collins, were given land grants in the early 1800 s. . . .

It is true that many people on the mountain made moonshine whiskey, and unless your [sic] were a relative or friend, you were not welcome until folks learned who you were and what you were looking for. They did not trust strangers, and to this day I understand why, although it is hard to explain. ...

There were many home remedies for illnesses: catnip tea for babies, mullen cough syrup, sassafras tea, and poultices galore. Mullen cough syrup was also used to help your kidneys. Sassafras tea was supposed to thin your blood. And onions could be heated in grease, put in a cloth bag, and applied to the chest for chest colds. .. . There was not much birth control around back then, so most households had several children. .. . If an infant was sick, the parents would send for an old granny lady around the next bend or up some valley, and she would know what to do....

Most people were down-to-earth, hardy outdoor workers with lots of endurance, some superstitions, and much good-heartedness. . . Most of the older people were farmers, but others were loggers, or worked in the coal mines, made chairs, brooms or built houses. . . .

A friend of mine has an old ragged diary passed down from one of his ancestors, who wrote: "While a prisoner of the Yankees, they walked from 
Knoxville, Tennessee, to Camp Chase Ohio. While crossing the Cumberland Mountain in winter, they found the guards in the area to be Melungeons. . . . The men guarding them were east Tennessee Renegades and deserters from the Confederate Army. They had not feelings for anyone, and would shoot a man for the most trivial offense. A large part of these men were from the (surrounding) area. 'Melungeons' they were called. They were definitely different from anyone (else) I have encountered."

The Melungeons as I knew them were not these kinds of men, though. . . .Those I knew, and know, adhered to the cross, planted their crops according to the signs, and reaped fruitful harvests. They were givers, not takers, and gave good measure to one another. . . . as the late Bill Grohse ${ }^{54}$ once said to me, "Take pride in your heritage." I certainly take pride in mine. ${ }^{55}$

Even in Johnson's positive and somewhat romanticized memoir, some dark themes are apparent — the history and effects of manufacturing moonshine liquor and the story of a gang of Melungeon vigilantes roaming during the Civil War. Her recital of other common markers-like the physical characteristics she describes, her mother's distinct aversion for the term "Melungeon," and reliance on herbal remedies and granny women for midwifery and medical advice — are true to form. Her record has the ring of truth, perhaps rose-colored by the warmth of her childhood in a secure and loving family.

\footnotetext{
${ }^{54}$ Bill Grohse was an "outsider" in the Vardy Valley married to Mattie Mae Miser, great-greatgranddaughter of Vardiman Collins. Grohse gathered many records and photographs relating to the Vardy community and became the acknowledged historian. He wrote a column and many articles for local newspapers.

${ }^{55}$ Mattie Ruth Johnson, My Melungeon Heritage: A Story of Life on Newman's Ridge (Johnson City, TN: Overmountain Press, 1997), ix, 1, 47, 128, 134, 136, \& 141.
} 
In some of the Appalachian fiction that has Melungeon characters, Melungeon Christianity is depicted as fundamentalist and especially as subscribing to a section in Mark's Gospel leading to handling poisonous snakes and drinking poison. The verses, which occur in a section of the New Testament text that some biblical scholars claim to be apocryphal, reads: "And these signs shall follow them that believe; In my name shall they cast out devils; they shall speak with new tongues; They shall take up serpents; and if they drink any deadly thing, it shall not hurt them; they shall lay hands on the sick, and they shall recover. ${ }^{, 56}$ Some churches in the Pentecostal Holiness denomination take these verses very literally; church services routinely include snake handling and the drinking of strychnine. Extended descriptions of such services appear in Lisa Alther's Kinflicks, and Jesse Stuart's Daughter of the Legend. There is also a remembered instance of such a church service in Johnson's memoir.

Occasionally, though, darker things happened and there would be special nights which I personally didn't care for. Word would get out faster than you could believe that there was going to be a snake-handling meeting ... Almost everyone would show up, Christians and even non-Christians alike.

The Christians knew that there would be a blessing from God that night and that it would be a good meeting. Some of them kept their snakes in cages at their homes, for, of course, snakes were easy to come by; ... I must say, too, that my parents never took up snake handling; I think they were as afraid of them as I was.... Usually only five or six people handled the snakes. They usually had rattlesnakes and copperheads, mostly the latter. Some snakes were large with fat

\footnotetext{
${ }^{56}$ Mark 16:17-18, KJV.
} 
bellies and seemed quiet. But quiet or not, they looked as mean as the devil to me. ... One man had lost his hand from a previous bite, and such things made me hate going to church on the nights they handled snakes....

All of the snake handlers were very righteous and believed in taking up the serpent. They would let the snakes climb up their arms and around their necks. They would even coil them around the tops of their heads and have them extended out on their arms, all the while shouting, speaking in tongues, and praising God. . . If someone got bitten, that was a certain show of a lack of faith. I knew my faith wasn't good enough to do that....

Being good Christian children, we had to dress well and go to church each time the doors opened; moreover, we had to sit near the front and behave. We weren't allowed to do anything during the meetings, and many nights I prayed that all those snakes would drop dead. ${ }^{57}$

This church, which is not specifically named in Johnson's book, was an integral part of the Newman's Ridge Community. Its practices stand in stark contrast to the Vardy Presbyterian Church, which was founded in 1899 by northern missionaries and stood on the principles of doing all things "decently and in order" as prescribed by the Presbyterian Book of Order. Certainly, knowledge of the snake handling is a part of the shared experience of those who have Melungeon heritage. The email list thread that I analyze later in this dissertation began with "Melungeon herbal medicine" on the subject line and morphed into "Snake handling." Johnson's vivid description of the snake

\footnotetext{
${ }^{57}$ Mattie Ruth Johnson, My Melungeon Heritage, 42-43.
} 
handling services of her childhood serve as a reminder of one of the salient features of Melungeon literacy from the inside.

\section{TELLING MELUNGEON STORIES}

Several decades have passed since scholars Ivey and Sovine scrutinized Melungeon stories. Work of contemporary folklorists such as Jan Harold Brunvand and Patricia Turner implies that some of the stories I have recounted for you under the rubric "shared experience" could be considered examples of Melungeon "urban" legends. The irony inherent in calling any Melungeon story "urban" should not go unnoticed here; Appalachian Melungeons are rural by tradition and by culture even when they migrate to America's cities. Brunvand allows that stories circulating in a particular community are usually about real people and real events, passed from one person to another by word of mouth, and capture fears and anxieties of the people who tell and hear them. He characterizes the stories of middle-class America as tales by plain folks that are strange, scary, funny, macabre, and embarrassing. They recount grueling ordeals and horrible threats, and issue pregnant warnings. They contain sexual themes and play on fears relating to challenges to the status quo by minorities and social inferiors. The Melungeon stories are, of course, the tales of the minority, of a group of social inferiors, yet they exhibit many of the traits Brunvand mentions.

Patricia Turner starts where Brunvand leaves off; her work explores the stories that circulate in African-American culture and show the mistrust of that minority for the power elite. Turner stresses the themes of contamination and conspiracy in African- 
American stories about tainted fried chicken or AIDS conceived as a government weapon of mass destruction that was tested in Africa and got out of hand.

These paradigms relate to stories about and by Melungeons in several ways. Some of them told mostly by outsiders about Melungeons seem to have been generated by middle class values and fears. The adage “The Melungeons'll git you, if you don't watch out!" is one example. Another emerges from Darlene Wilson's narrative about her job in the Norton drug store, where the owner is obsessed with the taint the Melungeon customers leave in the lunch counter booths. Superstitions about dangers relating to Melungeons tend to emerge in Appalachian writing: the fear that a boy baby born to a Melungeon girl will have black skin in Mildred Haun's short story “Melungeon Colored," the spat-out statement by a poor white mountaineer one step up the social ladder from the Melungeons of the upcountry south in Sharyn McCrumb's She Walks These Hills_- “Ain't no tellin' what them folk'll do," and the implication that inbreeding causes strange maladies and feeble mindedness that goes back to Dromgoole are examples.

There is a story that is often told by Melungeons and by others about how they came to live on the mountain ridges. This story maintains that they lost their rich bottom land to unscrupulous speculators who came waving pieces of paper at them and threatening them with court actions when the Melungeons themselves did not have any titles or deeds to their farms. This explanation was perpetuated by its inclusion in Walk Toward the Sunset, the outdoor drama about the Melungeons written by Kermit Hunter and produced in Sneedville from 1969 to 1977 . Author Brewton Berry, in his book 
Almost White, quotes a Melungeon woman who relates the traditional explanation about what happened to Melungeon people in the early 1800s:

Early in the last century (1800) when the white folk first come here, the Melungeons was already here, a "hold" all the good land, but didn't want to just take from the Melungeons brutal-like. Well, it wouldn't a been no trouble if the Melungeons was ordinary heathen Indians, They woulda “just kicked” em out. But there they was sorta "livin" liked civilized folks and they was "speakin" English, and "on top o" all that they was believing Christians. But their skins was brown on account "o" their Injun blood in "em" too. Then they passed a law saying "nobody with nigger blood could vote, or hold office, or testify in court." Then they went to court an before long they got hold "o" that good bottom land. So there wasn't nothing left for the Melungeons to do but move up on the ridges. 58

This story explains many things and is more interesting and exotic than saying that the ancestors came from Louisa County, Virginia, by way of the New River valley. It is a very prevalent account.

Other stories Melungeons tell on themselves emphasize coming out ahead in interpersonal encounters. Male sexual prowess is inherent in the stories my informants told about themselves and each other; the more people I met, the more stories I heard about sexual exploits of Melungeon men with their wives, mistresses, girlfriends, and about bastard offspring — just "good" times of "good ole boys." Melungeon storytellers also delight in relating instances when stupid white authority figures were outwitted like

\footnotetext{
${ }^{58}$ Brewton Berry, Almost White, (Toronto: Collier-Macmillan, 1969) 16-17.
} 
the one about Mahala Mullins being too fat to go through the door, which made her not arrestable, or the multiple stories about successful counterfeiting. Another story I got in my interviews was about the Vardy valley fire that was openly called arson; my informant was neither shocked nor surprised. The arson event was simply a fact she related to me in a matter-of-fact way.

Turner's work suggests that African-American "urban" legends draw on the shared experiences of blacks that go back to the early sixteenth century when white Europeans began to raid Africa. She sees the stories as tools of resistance for those who tell them, arising from real horrors, providing links to racial strife, and focusing on themes of contamination and conspiracy. Melungeon attempts to legitimize their ancestry by linking their heritage to a north American invasion by the Welsh Prince Madoc, by telling tales of wrecked Spanish or Portuguese galleons in the sixteenth century, by insisting they were in Tennessee mountain valleys before the legendary John Sevier arrived, show how they have tried to minimize the stigma that their dark skin caused. The story on the Melungeon email list about the young woman who was involuntarily sterilized keeps alive the real horrors Melungeons endured under Walter Plecker's conspiracy to ensure "racial integrity" in Virginia. The long tradition of calling themselves "Portyghee" shows how Melungeons tried to avoid racial marking and resultant prejudice.

The characteristics of urban, or contemporary, legends that Brunvand and Turner outline are apparent in Melungeon stories and Melungeon storytelling. The stories both spring from and form the mindset of these people. 


\section{WHAT MELUNGEON MEANS}

The elements of this chapter, what I am labeling "shared experience," seem to me to be essential components for my readers, who need some background about Melungeon people in order to make sense of my observations about the Vardy Community School, my discussion of Melungeon websites that are now proliferating on the Internet, and my analysis of one thread of discussion on the Melungeon-L. My readers need to construct a cache of shared experiences in order to be discerning readers.

Yet, as important as what Melungeon people already know is what they are still struggling to discover. While being Melungeon used to be something people hid when they could get away with it, many now are treating their heritage as something to celebrate. Ted Anthony tells a revealing anecdote about Connie Clark, Melungeon descendant, resident of Wise, Virginia, and an officer in the Melungeon Heritage Association. Anthony writes:

Connie Clark, who teaches in the Wise schools and counts herself as a Melungeon, remembers in eighth grade being assigned to trace her family history_-but to stop with her grandparents.

"I said, "What if we can go back farther?"” she recalls. "And they said, 'No-some people might not like what they find."'

Now here's the odd part: Today, though there remains passionately angry resistance, more and more people who believe they are Melungeon are going back further. 
But now they like what they find. ${ }^{59}$

The Melungeon descendants, the insiders, like what they find. I, a researcher and an outsider, also like what I find. And, it is my intention to present what I am finding and to add my insights to the growing body of informed speculation about the dark people of the southern Appalachians, the mysterious Melungeons.

\footnotetext{
${ }^{59}$ Ted Anthony, "Forging a Common Present," A:1.
} 


\section{Chapter 3}

\section{One Way to Tackle Barriers: Get Help}

\section{CHAPTER INTRODUCTION}

This chapter is the first of three that focus on the Presbyterian mission effort at Vardy, Tennessee, one area where Melungeon people have lived and farmed from the early 1800 s to the present. The Melungeons there, who were both immortalized and vilified by Will Allen Dromgoole's articles, in many ways exemplified all that was native and difficult in the Southern highlands. The valley was narrow, minerals were never found, and times were hard. By 1900 it was obvious that it would take at least a vision and a visionary to give the people hope. Vardy was fortunate enough to have not only one visionary, but three: Melungeon descendant Batey Collins, and missionaries Mary Rankin and Chester Leonard. Each of these people had a broad perspective; they took ideas and practices that were common in their times and modified them to effect amazing changes for Vardy residents. The next three chapters tell their stories, attempt to determine the sources of their inspiration, and reflect on their results.

\section{VARDY}

Vardy is a definite place, part of a narrow valley that runs northeast-southwest between Powell Mountain and Newman's Ridge in Hancock County, Tennessee. Vardy is named for Vardemon Collins, an acknowledged Melungeon and one of the earliest settlers of the 
region who received the land as a grant from the state of North Carolina. According to Vardy Community Historical Society member Cleland Collins, who grew up there in the 1930s, "The boundaries of Vardy, as I understood them, on the north would have been the top of Powell Mountain; on the south, the top of Newman's Ridge; the east, the Tennessee-Virginia state line; and on the west, the Mulberry-Sneedville Road."1

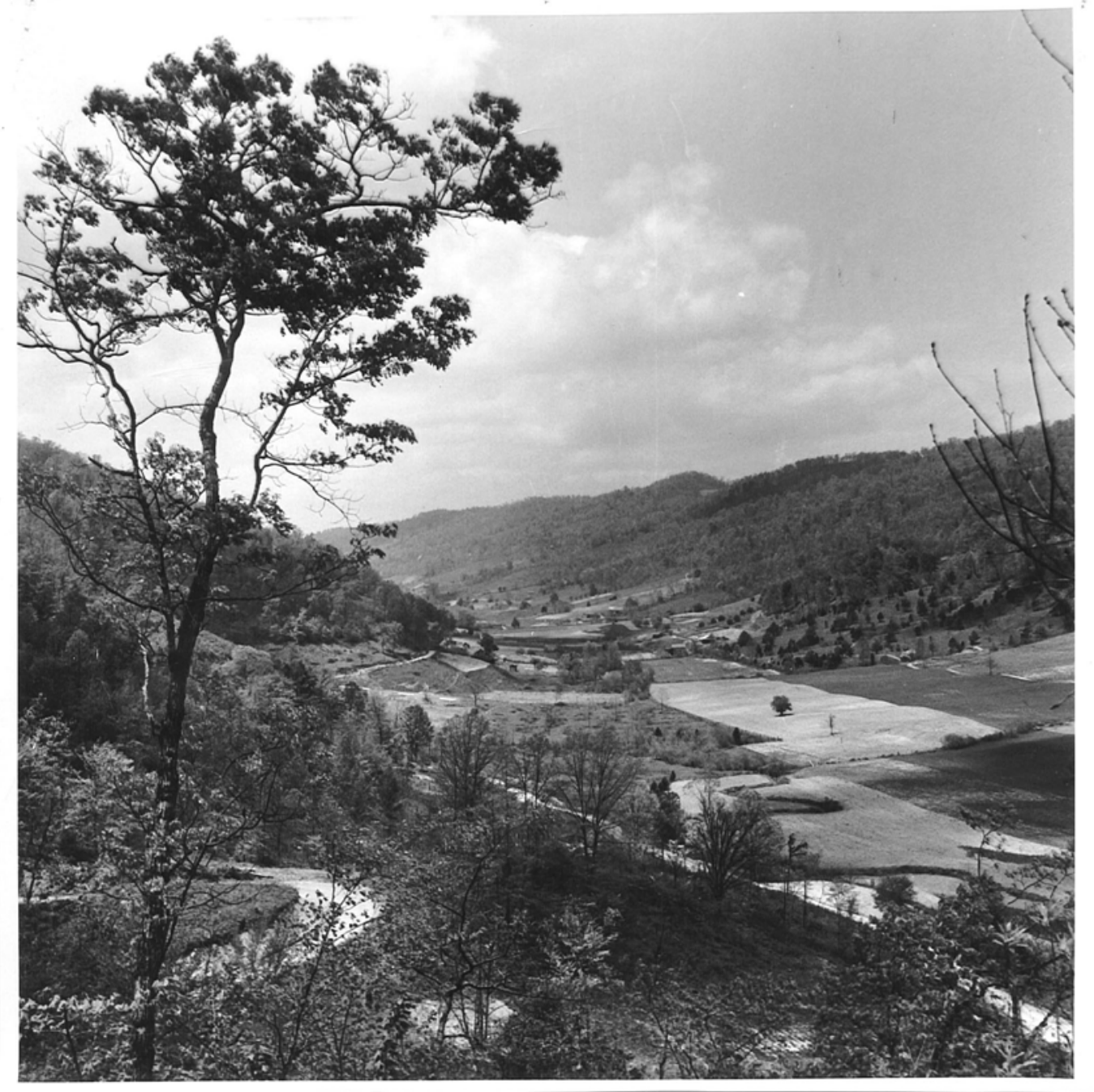

${ }^{1}$ Cleland Collins, Oral History Interview, quoted in Windows on the Past: The Cultural Heritage of Vardy, Hancock County, Tennessee (Sneedville, TN: The Vardy Community Historical Society, 2002), 13. 
The valley is narrow; there is some flat land along both sides of Blackwater Creek, but, at its widest point, the level arable land is not more than half a mile wide. A century ago the fields would have been sown in corn, sorghum, hay, or wheat. By 1930 most Vardy farmers were raising tobacco for cash. Today the cleared land along the creek is mostly pasture with an occasional tobacco patch. Some early buildings still stand in Vardy like the Sulphur Springs Baptist Church building and the newly restored Vardy Presbyterian Church Museum. What was the 1902 school building is now a private home. Anthony Collins, the current president of the Vardy Community Historical Society and a descendant of Vardemon Collins, lives in his old family home. However, most of the home places people remember from their childhoods in the valley are gone. Old barns, gray-weathered, lean at precarious angles, while new small and sturdy red-painted outbuildings bespeak different farming methods for a new era.

Although on a map the Vardy valley is a part of Hancock County, it is isolated by the very topography that defines it. A hundred years ago Sneedville, the county seat, was in many respects as remote as Nashville and was virtually inaccessible to the Melungeons. The road over Newman's Ridge was worse than difficult and the citizens of that small town were hostile. The barriers laws had erected in the 1830s barring persons of color from suffrage, education such as it was, and equality before the bench had branded the Melungeons as different. Even though these laws were rescinded in 1869, the "whiter" citizens of Hancock County had long memories and saw no reason to change their minds about accepting people they saw as being inferior to themselves. They only came to Vardy to buy moonshine or to solicit votes. When election-time passed, 
government functionaries demanded minimal yet costly participation: monetary in the form of property taxes and military in the form of service.

Drafting the young men off the farms and ridges must have seemed like an unreasonable demand, especially to the women they left behind to manage both house and field work. However, as I look at the history of Vardy, I see two remarkable things happening as a result of military service. Although some men died in battles or in hospitals where they were recovering from wounds, others came back to the isolated valley with either new awareness of the culture beyond the mountains or new friends who brought entrepreneurial energy, married sisters or cousins, and became leaders in the Melungeon community.

The awareness of Melungeon-ness, a literacy of understood and acknowledged difference, permeated people's consciousness in Vardy. They knew their place. Families' primary focus was survival. Theirs was not a cash economy; instead a barter system flourished. Growing and preserving food for winter consumption, gathering the bounty of nuts and wild plants for eating and for medicines, and hunting consumed the time and energy of the population. There were few opportunities to get any money. The literacy of reading and writing had little importance or relevance to everyday life. School, when it happened, was a cooperative endeavor. Individuals would subscribe money, foodstuffs, or free board for the teacher and hire someone to hold school for a few weeks or months. Pupils only came when they were not needed at home to work in the fields or cabins. There was a small $\log$ building built in 1869 to house the valley school, but the entire enterprise was a low priority. However, at least one person in Valley placed considerable value on education. Batey Collins, grandson of original settler Vardemon Collins, was 
different. He wanted more than the small valley had to offer, and literacy was part of his method for advancement.

\section{BATEY COLLINS, A COMMUNITY LEADER}

One of Vardy's veterans of the War Between the States, Batey Collins, must have had a life-changing experience in the Union Army, Company E, $8^{\text {th }}$ Tennessee Cavalry, where he served as a Private from 23 September 1863 to 11 September 1865. Batey (Baty, Beattie) Collins came home to the narrow valley and grew to the stature of a visionary leader in the Vardy Community. Born in 1845 to Alfred Collins (son of Vardemon Collins and Peggy Gibson) and Betsy Mullins, Batey was only 18 when he went to war. Back home in 1865 and then 20 years old, he quickly married. Cynthia, born in 1844, was either Cynthia Collins or Cynthia Goins. Her mother, Frankie Bunch Collins, was married to Simeon Collins, another son of Vardemon and his wife "Spanish" Peggy. Simeon died near the time of Cynthia's birth, and Frankie took up with a man named George Goins. Census data appears to verify the fact that Cynthia's father was George Goins. If her father was Simeon Collins, she and Batey would have been first cousins because their fathers were brothers. If her father was George Goins, they were no blood kin. I tell this story not to confuse but to illustrate how intricate family relationships are in the Vardy community where people thought nothing of marrying a double first cousin.

Batey and Cynthia Collins had four children, Frankie (1867), Noah (1868), Adelaide (1872), and Nancy (1881). In addition to farming, which was every family's main occupation, Batey was also an entrepreneur. He built a boarding house near the Vardy Sulphur Springs. Family stories relate that Grandfather Vardemon Collins and his 
wife Peggy had built a large double log house near the springs and that they kept travelers. Perhaps Batey was simply carrying on the family business. Batey's cousin Howard (Cynthia's brother if she was a Collins or her half-brother if she was a Goins) owned the mill in the valley and is also listed as a veteran of Company $E$ of the $2^{\text {nd }}$ Tennessee Infantry. According to the oral history narratives incorporated into Windows on the Past, both Batey and Howard were progressive in ways besides their business enterprises. They both valued education for their daughters, which seems an unusual thing for men in an Appalachian valley in the late 1900s. Batey's great-granddaughter, DruAnna Williams Overbay related, My grandmother Adelaide and several of her cousins were tutored, we believe, by the early missionaries who boarded with her father, Batey Collins. Before the missionaries came, they had learned to read and write, though. One of the earliest photographs we have of my grand mother has written on the back that she graduated at the top of her class, and she's wearing a first place

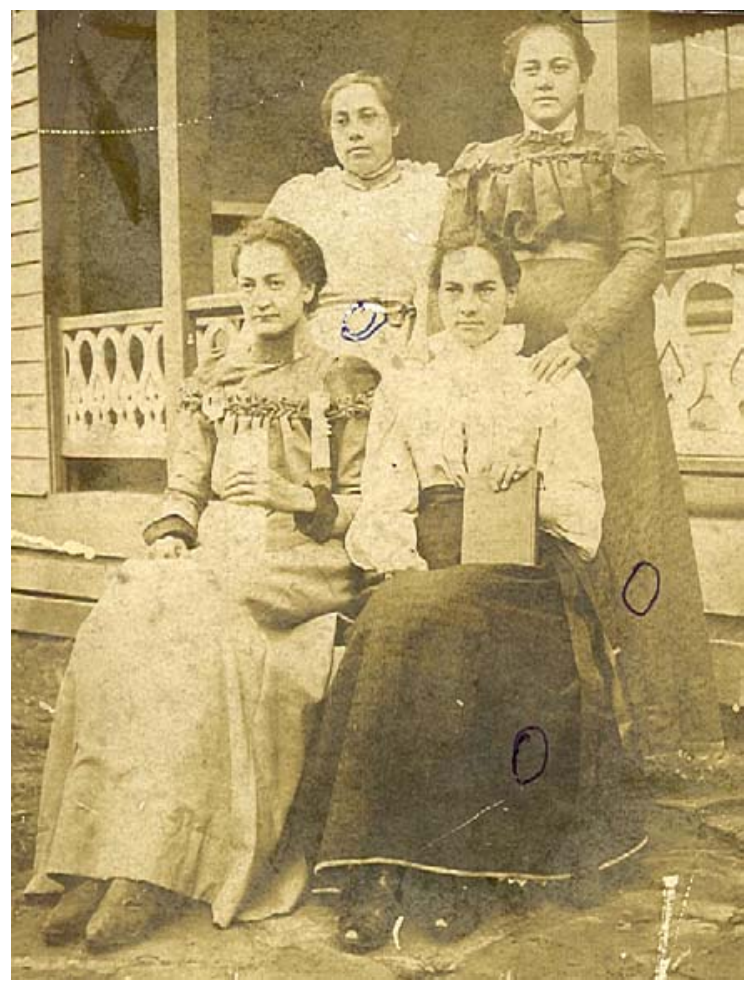

Adelaide Collins, daughter of Batey and Cynthia shown front left with her first place ribbon. Date unknown. ribbon. $^{2}$

\footnotetext{
${ }^{2}$ DruAnna Overbay, Oral History Interview quoted in Windows on the Past, 86. Mary Hamilton, author with David Barton of Local Literacies: Reading and Writing in One Community (London: Routledge, 1998) and contributor to Situated Literacies: Reading and Writing in Context ed. by David Barton, Mary
} 
These young ladies in their elegant dresses and shirtwaists in front of the Howard Collins home with its gingerbread porch balustrade hardly match the portrait of Melungeons living in poverty and squalor that Dromgoole paints in her Arena pieces. The value apparently placed on formal education sets the stage for the intriguing story of how literacy came to the Newman's Ridge Melungeons in the mountains of East Tennessee. Had he known the intricacies of literacy theory, Batey Collins might have said he favored the autonomous model: literacy defined as the skills of reading and writing which are associated with "progress," "civilization," individual liberty, and social mobility. ${ }^{3}$ The value he placed on formal education for his children, his son and his daughters, implies that he dreamed they might enjoy positions of competence and prominence beyond the narrow confines of their families and the Vardy valley. Batey Collins, as I imagine him, must have marked the literacy practices in the broader society that were evident in the buying and selling of land, the trappings of the military bureaucracy such as applying for pensions due veterans, business transactions, and high culture. He must have realized that inability to read and write would keep his relatives and neighbors from both accessing important texts and producing them. Marking a deed or bill of sale with " $\mathrm{X}$ " was not good enough.

In the $21^{\text {st }}$ century, literacy theorists would recognize that the Melungeon mountaineers did need to learn reading and writing. In addition, they would note that the mountain culture had literacies embedded in it that circumscribed and defined life. The most significant of these vernacular literacies were the methods of farming and food

Hamilton, and Roz Ivanic (London: Routledge, 2003), would cite this photograph as evidence of the social nature of literacy practices. She would call the practices shown here with the ribbons and books evidence of both display (the book being held) and ritual (the ribbons indicating prizes) that celebrate literacy in Vardy more than a century ago.

${ }^{3}$ Brian Street, Literacy in Theory and Practice (Cambridge, UK: Cambridge University Press, 1984), 2. 
preservation: planting, cultivating, and harvesting crops; tending animals, drying and canning fruits and vegetables, grinding corn to meal and wheat to flour; making molasses; butchering cattle and hogs; smoking and canning meat; burying root crops, fruits, and cabbages by packing straw around them in a covered hole in the ground to protect them from freezing. Other literacies existed and were sustained both by language (people learned them by being told) and by informal apprenticeships. Women made soap and apple butter in huge kettles outside over open fires. Recipes were passed from mothers to daughters. Logging and making moonshine earned a mountain man cash money in the rural economy. Blacksmithing, mid-wifery, herbal medicine, coffinbuilding, preparing bodies for burial, and knowledge of "the signs" were practiced by designated persons in mountain communities. Vardy was no exception to these folkways. These literacies made life possible, but they were of marginal value in the society outside the mountains, that was based on dominant literacies associated with formal education, the law, business, and main-line Christianity. This was the society that Batey Collins had glimpsed when he left Vardy in 1863 to join the Federal Army.

There was help available, and Batey Collins apparently knew where to get it. He connected with some enterprising Presbyterians. One of the most interesting stories about Batey Collins is told in print by an outsider, one Christopher Humble. Humble was a minister in the northern Presbyterian Church and was touted in the church's Home Mission Monthly as superintendent of Home Missions in Appalachia. In the September 1897 issue, Humble wrote an article titled “A Visit to the Melungeons." Humble opens by saying that on July $2^{\text {nd }}$ he and Rev. Joseph Hamilton "started in a hack from Cumberland Gap, Tenn., for Beatty Collins,' Chief of the Melungeons, in Blackwater 
Valley, Hancock County, Tenn.... He received us cordially and gave us full possession of 'Hotel Varday,' a frame building 12 x 14 feet, in which were three beds." ${ }^{, 4}$ These details are interesting in several respects. First, how did Humble happen to set out with Batey Collins's home as his destination? Did Batey invite him? If so, why? Was Batey perhaps familiar with the mission work of the Presbyterians in other areas of the southern highlands? Did Batey somehow believe that Vardy met the Presbyterian Church's criteria for a mission field? Second, the description and the photograph of the "Hotel Varday" are unique to this publication. No one in the Vardy Community Historical Society has ever seen the photo of the "hotel" that accompanies the article, and, furthermore, the oral tradition holds that Batey's hotel was an elaborate affair not just a building measuring 12 $\mathrm{x} 14$ feet. The third remarkable item is the reference to Batey as "Chief of the Melungeons." This term "chief" is also used by Dromgoole and other early writers; it points to open acknowledgement of Indian heritage, a fact that seems to get lost in some later speculations about Melungeon origins. Did Batey tell Christopher Humble that his title was "Chief of the Melungeons"? Or did Humble learn of Batey's status from others?

Humble in his piece goes on to recount some familiar history of the Vardy settlement. He tells about the arrivals of the first settlers Vardemon Collins and Shepherd Gibson and mentions that the "Goans, Miners, and Bells" came from North Carolina and were "charged with having Negro blood in them, and, before the war, were prosecuted on this ground for illegal voting." ${ }^{, 5}$ As I noted earlier, court records document the fact that Vardy Collins was among those prosecuted for illegal voting, but this is not mentioned by

\footnotetext{
${ }^{4}$ C. H. Humble, "A Visit to the Melungeons," Home Mission Monthly 11 (1897): 243. Punctuation in this quotation is reproduced exactly as it is in the original document.

${ }^{5}$ Christopher Humble, "A Visit to the Melungeons," 244.
} 
his grandson, who instead apparently told Humble that the community members suspected of having Negro blood are those who were singled out for prosecution.

There is an entire page of "A Visit to the Melungeons" devoted to Mahala Mullins (Humble spells her name "Mehala"). Humble mentions her twenty children, three of whom met violent deaths; her size; her occupation as seller of moonshine; the story of the county officers' attempt to arrest her, and he includes a unique photograph of the old woman sitting on her four-poster beside the barrel of 'shine with a measuring cup on top. Perhaps to bolster his case for establishing a mission at Vardy due to the immoral nature of moonshine making and selling, Humble relates both his conversation with her and his conclusions:

Privately, I said, "Why do you, so near the grave, go on selling this destructive stuff to the young men?" She replied, "It's the only way I can make a livin."”

She would only half promise to think of the evil of it. The old sentiment of the people makes it innocent, the notoriety makes it pleasant, and the money makes it profitable, and habit blinds her to the curse it has brought to her own door. ${ }^{6}$

The remaining page and a half of the article describes in some detail the five meetings that were held on July $3^{\text {rd }}$ and $4^{\text {th }}$ in the church (presumably the Sulphur Springs Baptist Church, although this name is not mentioned) at which Humble and Rev. Hamilton spoke along with other local preachers. Humble writes,

\footnotetext{
${ }^{6}$ Christopher Humble, "A Visit to the Melungeons," 245.
} 
In the afternoon, I organized a Sunday school and told them of the work done by our Bible Teachers. Mr. B.H. Williams, the Secretary of the Sunday School, Postmaster and Justice of the Peace, said: "Send the ladies right to my house, I'll take care of them.” Mr. Beatty Collins will give us a house and a piece of land, and all seemed anxious for these ladies to come. We have a competent lady, a native Tennessean, for whom $\$ 150$ is pledged, who is very anxious to enter this field. For her salary, we need another $\$ 150$.

Friends in Kansas are raising money to send another worker there, for two should go together. We will need at least $\$ 100$ to repair and remodel the house, $\$ 100$ more for stable, horse, etc., sums which we trust the Lord will shortly send us.

The door is open, the call is in our ears, the response will surely come. ${ }^{7}$ There are many things left out of this narrative that I would like to know. It appears that Humble was on a reconnaissance trip and that the outcome was pretty much a foregone conclusion. He went to Vardy to make arrangements for establishing a mission there. He does not tell how he knew about Vardy, whether he chose it or if Batey Collins issued an invitation. He does not tell how he knew Batey Collins. The organization and methods of the Home Missionary Society are taken for granted rather than explained. It appears that from Humble's perspective all the necessary elements are in place — an isolated mountain valley "divided into small farms upon which are rather

\footnotetext{
${ }^{7}$ Christopher Humble, "A Visit to the Melungeons," 246.
} 
poor dwellings and out-buildings," a young woman eager to begin her career as a missionary, and community leaders willing to provide a house. ${ }^{8}$

\section{APPPALACHIAN MOUNTAIN RELIGION VERSUS HOME MISSIONS}

Christianity in the mountains bore characteristics that distinguished it from mainline American Protestantism in the 1800 s and that persist to the present. The primary marker in indigenous mountain denominations and independent congregations was the centrality of traditions about the Holy Spirit. Preachers, who were often illiterate, were chosen by the Holy Spirit ("called") and ordained by local congregations. Preaching in these churches served to excite the passions and terrify the listener rather than inform the mind, convince the understanding, and then lead the individual believer to salvation in an orderly way. ${ }^{9}$ The important thing was the witness of the Spirit to each person; this was non-rational—based on desires, impressions and feelings, highly intuitive, and seated in the "heart." Churches recognized the autonomy of individuals and the priesthood of all believers. God's will was located in personal and communal experiences of the Holy Spirit; snake handling in church was one manifestation of this. Churches were independent and governed by consensus. According to church historian Deborah McCauley, the home missions movement that was emerging in the mainline denominations in the mid-nineteenth century "stood in opposition to what was tantamount to the very heart of what became Appalachian mountain religion." 10

\footnotetext{
${ }^{8}$ Christopher Humble, "A Visit to the Melungeons," 244.

${ }^{9}$ Deborah V. McCauley, Appalachian Mountain Religion: A History (Urbana: Illinois University Press, 1995), 351-52.

${ }^{10}$ Deborah McCauley, Appalachian Mountain Religion, 354.
} 
Mountain congregations, whether they were Cumberland Presbyterian, Baptist, Holiness, or something else, tended not to value seminary training for their preachers. This stemmed from their adherence to the grace-centered model outlined above and their isolation and distance away from institutions of higher learning. The congregations were poor and small because members walked from their homes; the idea of a minister who did nothing but tend to the life of the parish was foreign and unpractical. Knowledge of the Bible was often oral as was knowledge of hymns. Preaching adopted a "holy tone," a sing-song drawl interspersed with "ah" as the preacher caught his breath; listeners would sometimes sway to this rhythmic delivery. These hallmarks distinguished Christianity in the mountains before the missionaries came and undermined efforts to convert the locals to the mainline denominational modes afterwards. Existing side by side were two different agendas. The missionaries were usually blind to the fact that their "religion" seemed insincere and flat. The mountain people including the Melungeons in Vardy welcomed some of what the missionaries brought such as health care, schools, information about effective farming methods, but they merely tolerated the brand of religion. When the missionaries left, the planted churches usually died soon after.

The Christian America Movement that undergirded Home Missions efforts developed in the late nineteenth century at the same time that capitalistic industrialists and financiers were discovering and beginning to exploit the mineral and timber riches of the Appalachians. The goal of this movement was to create a homogenous Christian (Protestant) nation like the industrialized Northeast. The mountain people were targeted as an "unassimilated population" that should enter the mainstream. The capitalists dealt 
with the land; the missionaries were to "uplift" the people into the modern era. McCauley clearly delineates the willing cooperation of these two forces:

Both "the millionaire and the missionary" were interdependent in mountainous Appalachia during this time. The missionary exonerated the millionaire's exploitation of the region's natural and human resources by deeming necessary the "progress" the millionaire brought to the mountains. The millionaire, by bringing "progress" to the mountains, gave even greater urgency to the missionary's task of Christianizing/Americanizing mountain people as an unassimilated population. ${ }^{11}$

There was also a belief that the people in Appalachia represented a pure strain of Scots-Irish settlers that were untainted by immigration and were preserving a pure AngloSaxon heritage apart from what was becoming the melting pot of American life along the East coast. Some in the mainline churches advocated bringing these lost ones, a precious heirloom of Colonial times, back into the bosom of the churches. The key word was "uplift"- to modernize, Christianize, Americanize. ${ }^{12}$

Scholars in the field of Appalachian studies are quick to point out that the practice of the mainline protestant churches to send missionaries into the hills where the people were already Christians was bizarre. John C. Campbell, Secretary of the Southern Division of the Sage Foundation, a prominent person in the mission work that happened throughout the Appalachians noted in his study called "The Southern Highland Region," that the mountaineers resented the word "missionary," declaring, "We're no heathen;

\footnotetext{
${ }^{11}$ Deborah McCauley, Appalachian Mountain Religion, 398.
}

${ }^{12}$ Deborah McCauley, Appalachian Mountain Religion, 398. 
they needn't send missionaries to us. ${ }^{\text {13 }}$ Humble himself ratifies the mountaineers' assessment; in his report about his trip to Vardy he seemed impressed with the tenor and content of the meetings he attended. He noted that one preacher he met "is a perfect gentleman and an earnest Christian" and that "the sermon we heard was good in thought, arrangement and delivery." ${ }^{, 14} \mathrm{He}$ also said that many of the adults at the meetings affirmed their faith and that twenty young people indicated their desire to be Christians. Seemingly Vardy was a place where the gospel was known and embraced. Yet, Humble characterized Vardy in 1897 as "a splendid field for some personal work." 15

Batey Collins was a key person at the center of this enterprise as it is Collins' boarding establishment that is Rev. Humble's destination. The foray into the backcountry was the humble beginning of the Vardy Presbyterian Center. Collins's donation of the land for the church and the school was a significant gesture that enabled the start of what became the Presbyterian mission enclave in the heart of the Vardy Community. The strings Batey Collins attached to his gift of land are still being untangled today by his numerous descendants. Christopher Humble's brief visit to what he calls the Blackwater Valley and the decisions made as a result of it were to change Vardy forever. The people who had long been excluded from Hancock County society were about to be included in a turn-of-the-twentieth-century Appalachian phenomenon.

\footnotetext{
13 John C. Campbell quoted in Samuel Tyndale Wilson, The Southern Mountaineers, New York: Presbyterian Home Missions, 1914).

${ }^{14}$ Christopher Humble, "A Visit to the Melungeons," 246.

${ }^{15}$ Christopher Humble, "A Visit to the Melungeons," 246.
} 


\section{PRESBYTERIAN HOME MISSIONS}

To put the Vardy mission in perspective it is necessary to understand some things about the Presbyterians. Because having a seminary degree is a requirement for ordination to the ministry of word and sacrament in the denomination, Presbyterians have from colonial days founded schools, colleges, and seminaries. They have been convinced from their earliest settlements in North America that education is of primary importance not only for the clergy but also for the laity. Presbyterian polity is based on a representative democratic system. Individual churches are run by elders elected by individual congregations. These elders in turn elect representatives to the presbytery, which elects representatives to the synods. The General Assembly, a broadly representative group of elected delegates that governs the entire denomination, meets once a year. Individual congregations in the Presbyterian system are not autonomous, and church buildings, even though they are built, paid for, and maintained by a particular congregation, are owned by the local Presbytery. This system depended in 1900, and still does depend, on a literate laity.

A second reason for the high value placed on education is the importance of Bible reading in the Presbyterian tradition. The Bible, according to the catechism, is the infallible guide for faith and practice. Available to every believer, the Bible is central, and each church member must be able to read it. Furthermore, reading the Bible because of its status as the inspired Word of God would lead persons to embrace it as true and become converts to the Christian faith.

Presbyterians have also founded and maintained hospitals around the world as a part of their mission outreach. "A healthy mind in a healthy body" is one of the guiding 
principles of Presbyterian mission work. Both education and public health work were important at Vardy.

Another important fact that plays into the Vardy story is the schism of the Presbyterian Church that mirrored the split of the nation at the outset of the War Between the States. Churches in the States that had been part of the Confederacy belonged to what became after the war the Presbyterian Church in the United States. Churches in the north were part of the Presbyterian Church in the United States of America. This split persisted until 1982, when much-debated "Reunion" finally occurred. Tennessee, being a border state with persons having strong loyalties to both causes, had churches in both denominational organizations - the southern and the northern Presbyterian churches. These two bodies were in real competition for the hearts and minds of people in the former Confederate states. Individual churches in Tennessee chose which body to belong to. ${ }^{16}$

Both the northern and southern Presbyterian churches had day schools, colleges, and home mission operations in the mountain south. Right after the Civil War the northern church had thought that it would re-establish itself in the South by ministering to the freed slaves. But, not only were the slaves not interested - they preferred instead the African Methodist Episcopal and Baptist affiliations—but, ministering to them alienated white southerners. So by 1880, the northern church had turned to Appalachia as its site for good works.

\footnotetext{
${ }^{16}$ For example, King College, where I teach, was founded after the war by the Synod of Appalachia of the southern church because the three existing colleges in East Tennessee, Maryville in Maryville, Washington in Washington College, and Tusculum in Greeneville, had been founded by Presbyterians before the war and chose to stay with the northern church. The PCUS founded King in order to compete for students and to have a place to train young men for the ministry in the region.
} 
In a fascinating book called The Southern Mountaineers (1914), Samuel Wilson, then president of Maryville College and the Stated Clerk of the Synod of Tennessee, tells the story of the Presbyterians in the northern church and their mission efforts. The Foreword announces "No other part of the field appeals to the heart with more romantic interest than does that included in the southern Appalachians. ${ }^{, 17}$ This book is an eyeopening account of what principles drove the movement, what the missionaries did, and what they thought about their work and their "clients."

Unlike Humble in his brief article, Wilson sets up the rationale for home missions telling both why mission work was needed and what should be done. Early in his book he delineates three classes of people living in Appalachia:

1) Nominal mountaineers - the large populations in the wide fertile valleys of the Shenandoah and East Tennessee who have established centers of trade and commerce.

2) Normal and typical mountaineers - people who are isolated from the valley centers of culture yet have kept their "rugged character and sterling qualities of their race." Members of this class are self-sufficient and demonstrate lively native intelligence.

3) Submerged mountaineers - "poor whites" or "white trash" that constitute a group of "shiftless, ambitionless degenerates," the lowest class in the mountains.

Wilson notes that individuals of this third class were keenly sensitive to slights real or imagined, and, therefore, somewhat difficult to deal with. He then opines, "The class

\footnotetext{
${ }^{17}$ Samuel Wilson, The Southern Mountaineers (New York: Presbyterian Home Missions, 1914), v.
} 
would be a very hopeless one were it not for a quality that will be referred to again; namely, the fact that it can be made over in one generation."18

Wilson waxes eloquent as he defines what he calls the white or Appalachian problem:

It is presented principally by the third class of the mountaineers of the South, ... sorely in need of our Christian sympathy and help....

$[T]$ hey are our belated brethren: they are behind the times; . . they have thus far missed the twentieth-century train. ... [T]hey form a submerged classnot submerged by the waves of advancing civilization, ... but submerged in sylvan solitudes and seclusion, and sometimes buried in backwoodsman idleness and illiteracy. ${ }^{19}$

Wilson goes on to posit that the problem is uniquely American (no foreigners to speak of live in the region) and Protestant (Roman Catholics number few to none) and white (virtually no mountaineers owned slaves). He also calls the problem "country," noting that save Asheville there are no cities in the region. The people are practically all farmers; " $[t]$ heir life is ideally bucolic. . . if it were not for the sheep-killing dogs, the mountaineers might easily be the greatest pastoral people of modern times. ${ }^{20}$ It's not hard to imagine where this rhetoric is headed. Wilson is setting up the rationale for going into the mountains to tidy things up: build schools, eradicate disease, and change the people in just one generation. The Presbyterians were unable resist the temptation to clone themselves and make the mountaineers into modern, middle class Americans. They

\footnotetext{
${ }^{18}$ Samuel Wilson, Southern Mountaineers, 23.

${ }^{19}$ Samuel Wilson, Southern Mountaineers, 43.

${ }^{20}$ Samuel Wilson, Southern Mountaineers, 48.
} 
thought they were simply bringing schools and clinics to make life easier in the mountains, but they were, in short, bringing a different way of life. Whether they knew it or not, their agenda was cultural transformation.

Wilson deserves some credit as he does recognize he is in a touchy situation. He acknowledges that those who would help must never be patronizing, "As quick as a flash the mountaineer will recognize and resent the intrusion of any such spirit, and will refuse even what he sorely needs, if he detects in the accents or the demeanor of the giver any indications of an air of superiority." ${ }^{21}$ Wilson encourages workers and would-be workers to refrain from rehearsing any praises of other sections of the country and from mentioning any deficiencies of the mountains and admonishes them further: "The success of a worker in the mountains has sometimes been greatly and needlessly endangered by the writing of an injudicious letter that has gotten into print and then has found its way back to the place where it was written, to embarrass its author and to injure or even to destroy his usefulness. ${ }^{22}$

Even though Wilson and others like John Campbell urged caution, the "work" was undertaken with great zeal, and both Presbyterian ecclesiastical bodies established churches, schools, and community centers in Kentucky, Tennessee, and North Carolina. Catherine Marshall's novel Christy, based on her mother's experience at a Presbyterian mission school in the early 1900s, is an interesting look at the mission school phenomenon from a young woman missionary's perspective; Christy became a successful television series and has spawned an ongoing outdoor drama at Townsend, Tennessee, in the Great Smokies. Another novel, Harriet Arnow's Mountain Path (1936), was written

\footnotetext{
${ }^{21}$ Samuel Wilson, Southern Mountaineers, 51.

${ }^{22}$ Samuel Wilson, Southern Mountaineers, 51.
} 
much earlier and chronicles a city woman's sojourn as a rural mountain school teacher. The recent Hollywood film, Songcatcher, directed by Maggie Greenwald, is a somewhat melodramatic look at mountain "work" of the same period; it is unremarkable save for the music on the soundtrack.

\section{THE SETTLEMENT SCHOOLS}

The Presbyterians were not the only ones interested in bringing the mountaineers into the mainstream of early $20^{\text {th }}$ century American life. Other denominations and secular outreach societies were involved. Hindman and Pine Mountain Schools in Kentucky, the Berry Schools in Georgia, Caney Creek School that became Alice Lloyd College in Kentucky, and the John C. Campbell Folk School in North Carolina are examples of other efforts to educate mountain children and make life more up-to-date for all. The settlement schools in Appalachia both Christian and secular were modeled after urban settlement house efforts among poor and often foreign-born children and adults who came to America's cities. Another factor in the schools' development was the growing number of educated women in the United States. Even after the turn of the $20^{\text {th }}$ century, many professions like law, medicine, dentistry, or the ministry were closed to women, who did not at that time even have the vote. Yet, women were graduating from high schools and colleges in larger and larger numbers with the broadened perspectives that formal education can bring. There was a climate of social reform in the United States, and these young women were eager to contribute; teaching at the settlement schools was a way to make a difference. Local people referred to these crusaders as "fotched-on" women, "fotched-on" meaning that they had been "fetched" from outside the area to 
come and work in the new schools and community centers. Some women, like Katherine Pettit, May Stone, Alice Lloyd, and Martha Berry, as well as Vardy's Mary Rankin, were life-long crusaders in the schools where they served. These women never married or had children of their own, yet no one would dispute that their descendants are many.

The schools became community centers for the isolated areas where they were located, offering health clinics, agricultural institutes, and entertainment for community members. Some schools promoted the making and selling of craft items like carved wood pieces, quilts, and hand-woven coverlets. Some mountain workers collected local music and stories. David Whisnant, in his book All That Is Native and Fine: The Politics of Culture in an American Region, is critical of some of the practices in the mountain schools, noting that only certain kinds of music and/or traditions were acceptable. For example, English and Scottish ballads were prized, but the music that became bluegrass and country was seen as common and not "collectible."

Interesting insights into the settlement schools are provided in a series of what critics have termed "documentary" novels by Lucy Furman. Furman was herself one of the "quare" (queer) women who worked at Hindman in its early years. She is credited with documenting mountain culture as it was in the process of being radically altered not only by the settlement schools, but also by industrialization. 
Mountain workers gathered every summer at various conferences to talk shop and report to each other on successes and failures in their various settings.

The first conference for Presbyterian

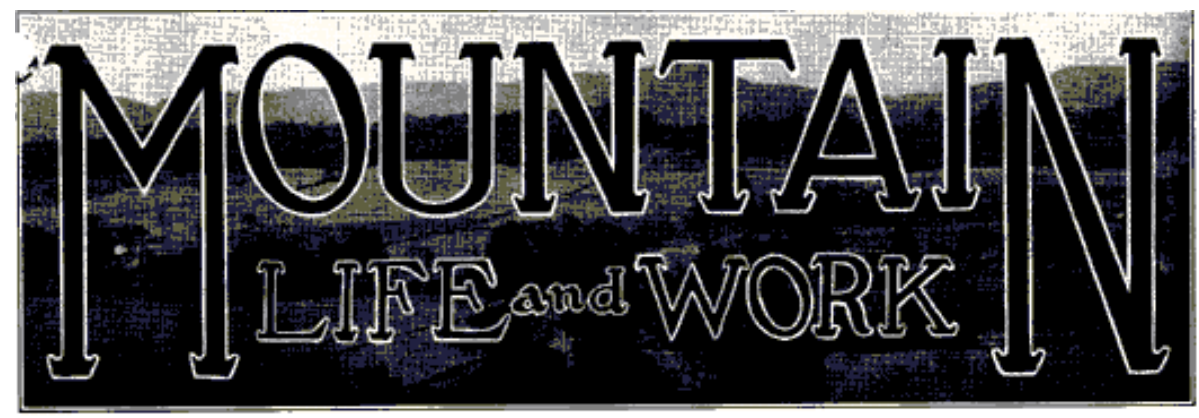

\begin{tabular}{lll}
\hline Volume I & APRIL, 1925. & Number 1 \\
\hline
\end{tabular}

workers occurred in Atlanta in 1920, and there was a conference at Warren Wilson College in Swannanoa, North Carolina, as late as 1946 for southern rural workers. A journal called Mountain Life and Work began to be published at Berea College, Kentucky, in 1925. The editor stated the purpose of the magazine in its first issue:

The mountains are poorly understood and insufficiently appreciated. It is a region of vast resources that has been blocked out of the wild by a great people and held in trust, as it were, for the modern capitalist to develop and utilize. . . . Interest in the mountains heretofore has been largely of the patronizing kind, the alms-giving variety for the "uplift of the mountain whites"... . To reach a real understanding of the true mountaineer will require a modification of many concepts of his life and habits that have been built up around him. Not only is it necessary to change the thinking of the outside world regarding him, but he must be brought to a different understanding of himself. It is to bring about these two ends that MOUNTAIN LIFE AND WORK is launched. ${ }^{23}$

\footnotetext{
${ }^{23}$ Vaughn, Marshall E. "Purpose of this Magazine," Mountain Life and Work 1, no. 1 (1925), 2.
} 
These ideas are very similar to Samuel Wilson's in The Southern Mountaineerspassions to reform life in the Appalachian region because of the perceived "Appalachian mountain problem" and a guarded acknowledgement that there were some inherent difficulties in the situation for mountain workers.

The backdrop against which the Vardy Presbyterian Mission played has several important components. The first is the land itself. The ridges made the narrow valleys hard to get to, and the rocky soil made farming difficult. Yet, subsistence farming was the primary work of most in the Vardy valley. Times continued to get harder because mountain families were large, and by 1900 there was simply not enough land left to support everyone. At the same time, the settlement schools were becoming an important enterprise in the hills. There were normal schools and industrial institutes being established in many Appalachian communities. For the particular setting at Vardy, the Home Missions movement in both of the Presbyterian denominations was very important.

\section{PRESBYTERIAN MISSIONARIES ARRIVE}

According to Windows on the Past, the Vardy Presbyterian Church was started in 1898. The Vardy Community Historical Society sometimes celebrates the dedication of the Vardy Church in February 1899 with a commemorative service. The records of the Church Session do not begin until 1902. The building, very grand for the region, was divided into two parts: a sanctuary area with pews that faced a platform fitted with lectern, pulpit, communion table, and pump organ. The entry was separate and to the right of that was a long narrow room that extended across the front of the building where Sunday School classes met and the church library was housed. Large plain glass windows 
on all sides let in the light, and beaded board paneling, unpainted in the early years, completed the décor.

The first two workers, both young single women, were Margaret McCall, a Washburn College graduate of Topeka, Kansas, and Annie Breem Miller of Rogersville, Tennessee. Danny Turnmire, a Hancock County educator, found a report by Margaret

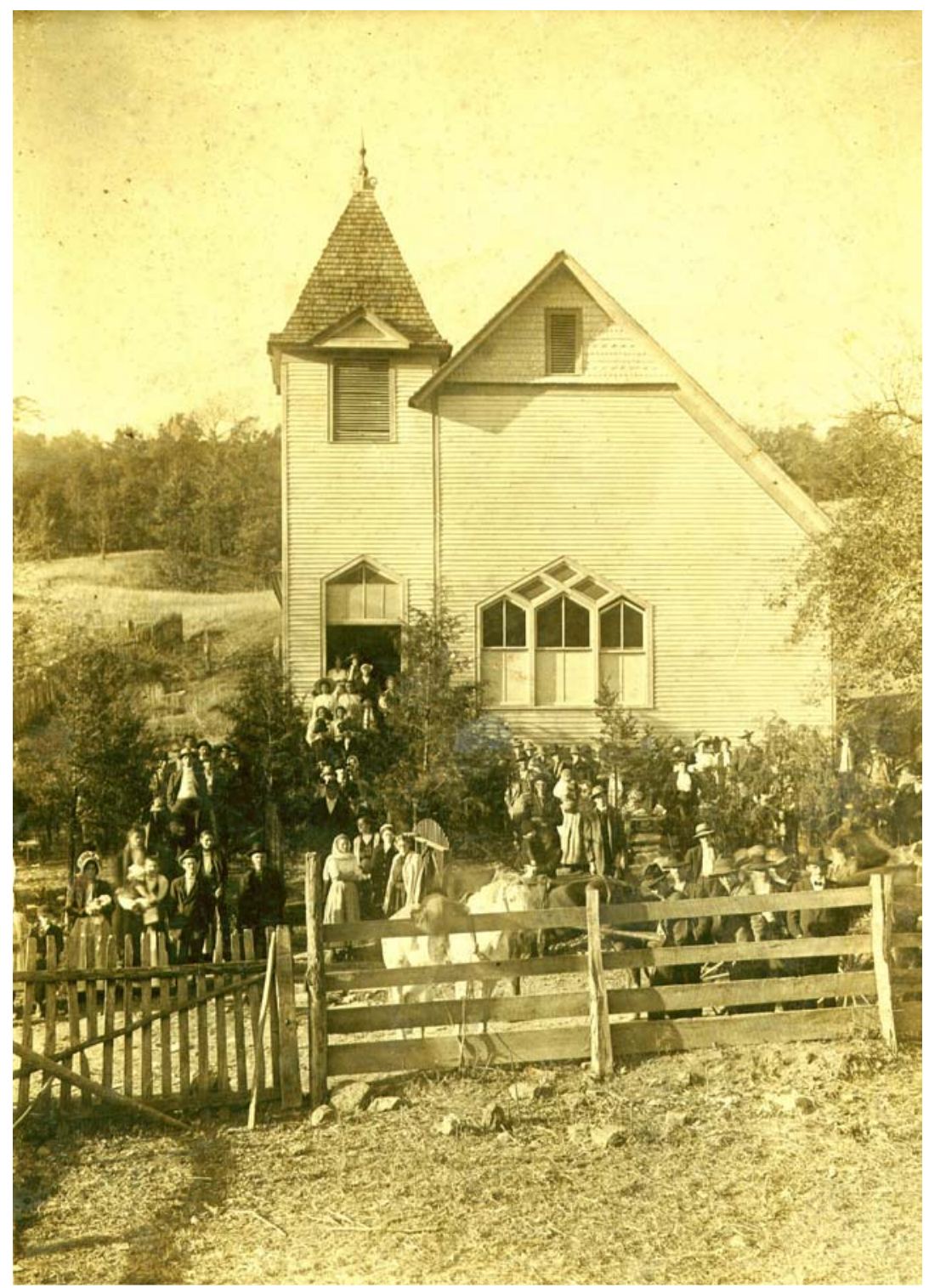

Vardy residents pose in front of their elegant church building, circa 1910. 
McCall in an unpublished document, "History of Education in Hancock County;"

McCall's words are interesting and informative:

We were the first workers there, rode the same horse together, visited in the many cabin homes together, and had many pleasurable and pioneer experiences.... They made moonshine whiskey and had "blind tiger ${ }^{24}$ there and felt that they could not send a man worker there, but only women. My father came down and put us up a cabin. ... He made a house with one large room where we could have Christian Education Meetings, and a kitchen and two small bedrooms. We had school one day a week, Sunday School, and visited in the homes. Before I left, we had two Sunday Schools in our valley (and) two in the valley over Newman's Ridge (Panther Creek), and one on the Ridge on Thursday. Nancy Collins was our constant friend and through her we got over our messages about not liking people to stand outside the windows and spit tobacco juice inside, about washing dishes

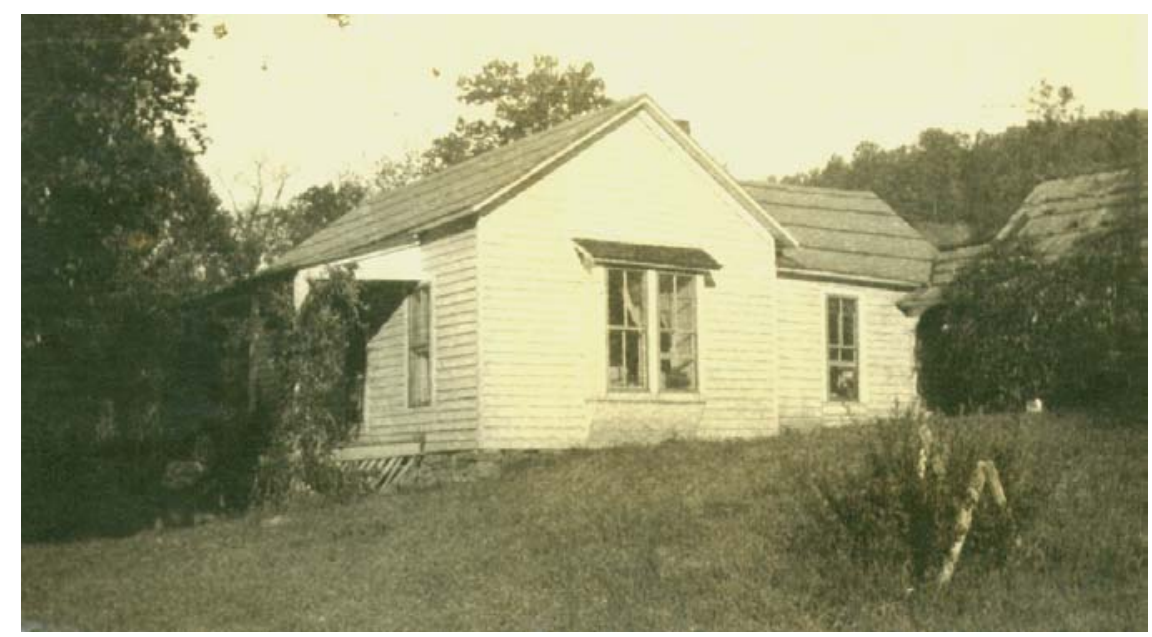

The first mission house just west of the Vardy Church, probably built in 1920 .

${ }^{24}$ A "blind tiger" was a place to buy moonshine. 
in clean water, and about drying them. ${ }^{25}$

Several details in this recital are noteworthy. First, the house that Batey Collins had promised Christopher Humble he would provide for the missionaries apparently did not immediately materialize. There was a house, pictured above, that the missionary women lived in next to the church, but the record indicates it was built around 1920. It's possible that the log cabin Margaret McCall mentions is the vine-covered building at the right. Second, the women held several "schools" each week at different locations and visited in the homes of people in the community. Third, Nancy Collins, Batey's youngest daughter, befriended the young women and served as their advocate among Vardy residents who were obviously curious about what was going on at the missionaries' cabin. Fourth, the beginning of instruction in sanitation practices is documented - the dishes were washed in clean water. These "fotched-on" women were surely teaching basic reading and writing as well as Bible content. They also had started on the list of objectives that Wilson documents in his book. Specific teaching of skills, the imparting of Biblical content, and overt modeling of new literacy and life practices constituted the missionaries' regimen. So began the work at Vardy.

\section{THE PRESBYTERIANS’ PARADIGM}

The Presbyterians were very serious about the situation in the Appalachians.

Characterizing themselves and their ecclesiastical institution as "the broadest and most tolerant in Christendom," they recognized the "Appalachian problem," and they felt that

\footnotetext{
${ }^{25}$ Attributed to Margaret McCall, by Jimmy G. Mathis, "History of Education in Hancock County" unpublished report presented to Education Department, Lincoln Memorial University, Harrogate, TN, 1982 by Danny Turnmire, "Education of the Melungeons" M.A. Thesis, Union College, 1984, 22.
} 
solving that problem — since they were convinced they had both the wherewithal and a method — was their mandate. ${ }^{26}$ Samuel Wilson's book is earnest; the zeal of the institutional church and other clergy like him shines through his Babbit-sytle rhetoric.

The church saw the solution to the problem consisting of three simultaneous initiatives: 1) economic development, 2) improvements in the public school system, and 3) "the multiplying of uplift agencies of the various churches and of other philanthropic organizations. ${ }^{, 27}$ The Mission Board did not have the power to effect the first two, so they instructed workers to concentrate with vigor on the third one. Wilson's book says that being a national denomination, the Presbyterian Church was obligated to serve citizens across the breadth of the nation including Appalachia. He claimed, however, that the church should have no plan to make people into Presbyterians ${ }^{28} \mathrm{He}$ recognized that "faithful servants of Christ ... have cared for the religious interests of the Appalachians" and that Presbyterians should go into the field to offer aid and to reinforce the work of Christians already there by introducing "a fresh body of workers into a region where the force [then] employed [was] on every hand confessed to be pitifully inadequate. ${ }^{, 29}$ While noting in passing that "a permanent, shining Presbyterian church [would] be one of the greatest contributions to a mountain county that our zealous Church [could] make," he affirmed that the main thrust of the Presbyterian work in the mountains must be education. ${ }^{30}$ Training of young people to take leadership roles in the mountain counties

\footnotetext{
${ }^{26}$ Samuel Wilson, Southern Mountaineers, 100.

${ }^{27}$ Samuel Wilson, Southern Mountaineers, 96.

${ }^{28}$ By 1914 when Southern Mountaineers was published the social gospel of Walter Rauschenbusch was coming into vogue in the mainline denominations. More discussion of this movement will be included in the section on the ministry of Chester Leonard, Vardy's first, last, and only full-time pastor.

${ }^{29}$ Samuel Wilson, Southern Mountaineers, 100-01.

${ }^{30}$ Samuel Wilson, Southern Mountaineers, 102.
} 
could in just a generation make the transformation of the economy and the schools happen faster than outsiders' imposing changes could do.

Although Wilson writes in detail about all aspects of the Presbyterians' Home Missions efforts, the chapter titled "The Day-schools and Smaller Community Centers" is most relevant to the work at Vardy. Vardy children did go off to the boarding schools at Asheville, North Carolina, and some attended Maryville College, Berea, and Lincoln Memorial. However, the eight-part program he outlines is the blueprint for the Vardy Presbyterian Center. The two hallmarks of the broad Presbyterian plan that stand out in sharp relief are policy of no proselytization and the intention that the mission would be an interim solution for educating the children until the county schools should be ready to assume responsibility for quality instruction. These two principles insured, at least in the case of the church and school at Vardy, that the Presbyterians' institutions would only be temporary.

Before going into his detailed discussion of the eight-part plan, Wilson describes the pattern for initiation of a mission site that I have already narrated in my account of Christopher Humble's short visit toVardy at the invitation of Batey Collins. Wilson calls Humble and his ilk "Presbyterian sky-pilots." ${ }^{31}$ Such men would visit a locality, determine the needs of the place, and secure the promise of land and a house or cabin; then the Presbyterian system would take over and provide two community workers. Says Wilson, "the coming of the teachers meant the regeneration of the community. ${ }^{32}$

The Presbyterians' agenda must have felt like radical future shock for the small isolated communities chosen as mission sites. Their practices were driven by their

\footnotetext{
${ }^{31}$ Samuel Wilson, Southern Mountaineers, 112.

${ }^{32}$ Samuel Wilson, Southern Mountaineers, 113.
} 
ideologies: Darwinism, Manifest Destiny, and the eradication of the Native Americans and the Indian cultures were all facets of the "uplift" enterprise. Blinded by their presuppositions, the church planners and visionaries thought their ways were the only ways to bring about change. Autonomous literacy was a key piece of their program. Once the children and the adults learned to read and write with ease, they would surely cooperate with the society at large and buy into its capitalistic agenda.

The young missionary women were sponsors or mediators of literacy and charged with intervening in the mountain culture; they had no small task in front of them. Wilson's Southern Mountaineers outlines the steps they were to take that would usher the backward indigenous society into sparkling modernity. First, they were to establish a home that would in its furnishings, comfort, neatness, and home-likeness become a model for the people who would come to see it. Margaret McCall and Annie Miller must have been quite successful in this regard because they reported the locals were peering in the windows watching all they did. The Board of Home Missions charged the young women to hold demonstrations and trusted that reformation in local practices of daily living would follow.

Second, the workers themselves were "consecrated" by their call and expected to exemplify unselfishness, genuineness, and Christlikeness. Under constant scrutiny by members of the community, they should testify by their lives and so show forth the truth. This silent testimony was thought by the Board to be their strongest influence. The third charge was to "open the book world—-[and isn't that, after all, the entire world?] — to the delighted world of their pupils." ${ }^{, 33}$ If they were successful, they would be "oracles of the

\footnotetext{
${ }^{33}$ Samuel Wilson, Southern Mountaineers, 114.
} 
children, and to a considerable extent, the authority of the adults. ${ }^{\text {} 34}$ They were charged with the responsibility for the sweeping changes envisioned for the Vardy community as well as other mission stations.

Fourth, even though their transparent lives were their most important testimony, the workers were expected to train the girls and the women in the community in domestic science and home economics — nutrition, cooking, sanitation, and dressmaking. In addition, they were to make home visits. Fifth, there was to be industrial training at the day schools, crafts like spinning and weaving for the girls and woodworking for the boys. Sixth, community workers were admonished to take advantage of government programs and private agencies' offerings in their regions of service to teach agriculture and horticulture.

The seventh emphasis of the Presbyterian program was Bible study. The workers in many places were called "Bible readers." Wilson quotes one Dr. Calvin Duncan on the methods of the Bible Readers:

The women employed as Bible-readers establish a model home where Christ is first in all things. The house is inexpensive, yet neat and comfortable. It is kept clean within and without. Great care is taken to comply with all sanitary conditions. Choice flowers bloom in the yard, and the premises are made as attractive as possible. Mothers' meetings for prayer and Bible study, sewing of garments and helpful conversation, are held in this home. Then the homes of the people are visited, the sick and dying are ministered to, and words of comfort are spoken to the bereaved. In some instances medicines are supplied and

\footnotetext{
${ }^{34}$ Samuel Wilson, Southern Mountaineers, 114.
} 
administered. The Sabbaths are full of work, these women often superintending the Sabbath-school, leading the singing, and doing most of the teaching. Then there is the young people's meeting and the prayer-meeting work. It seems to me that if our Saviour were here on earth he would be doing just such work as these good women are doing. ${ }^{35}$

Wilson's and Duncan's assumptions are many; they apparently have no inkling that the program could be anything but beneficial to all concerned.

The final of the eight principles for the mission work was seen as the sum of the previous seven: there would be evidence on site of "clean morals and pure religion . . .one common flood of spiritual blessing for the neighborhood and the school. ${ }^{" 36}$ Wilson claimed that the results at the mission sites were immediate and that the young people, whom he saw as the hope of the future, were quickly transformed. In addition, a church often grew in the target community to serve the newly enlightened constituency. The literacy program envisioned by the Presbyterians was comprehensive. They would have defined literacy as "reading and writing," yet they were in fact doing literacy as social practice. Literacy events, which new literacy studies theorists define as activities where a written text has a role, were occurring in formal classrooms, in homes where the Bible was the text under discussion, and in the missionaries' houses around the practices of cooking, sewing, and home-making. Farming journals and broadsides from the Department of Agriculture were available to the men in the missionaries' houses and at the schools; these gave suggestions for ways to make the land more productive and to change other agricultural practices. The lives of the adults and the children were

\footnotetext{
${ }^{35}$ Samuel Wilson, Southern Mountaineers, 117.

${ }^{36}$ Samuel Wilson, Southern Mountaineers, 118.
} 
beginning to incorporate texts in places where oral language and or situated practice had previously been the focus. Adults wanted to read to participate in these new activities. All domains of community life — home, church, and school—were impacted by the radical and comprehensive programs the Presbyterians brought.

\section{THE VARDY MISSION IN THE EARLY YEARS}

Mission workers, all women, came and went during the first decade of the twentieth century. The church pulpit was supplied by many different seminary-educated preachers from Holston Presbytery (northern church) and the denomination at large. Calvin A. Duncan, quoted in the previous section, not only preached at Vardy January 29, 1911, but he is also a prominent figure in the church records telling of a series of prayer services that were organized by the valley's Bible Reader Mary J. Rankin. The notes he made demonstrate the effectiveness of this remarkable missionary to the people of Vardy. At the time of the prayer meetings, Rankin had been in Vardy less than a year, yet "[ $[$ the cooperation of other denominations in the neighborhood was secured." ${ }^{37}$ Several people professed their faith and were baptized by Duncan when he preached that January Sunday. Mary Rankin was working magic in the community.

If Vardy Protestants could confer sainthood, they would so honor Mary Rankin.

Miss Rankin, as she is known by everyone in Vardy, was born in Scotland and grew up on 320-acre farm near Thief River, Minnesota. The oldest of eight children, she helped

\footnotetext{
${ }^{37}$ By using the plural here, "denominations," Duncan probably means at least one Baptist church and possibly the Holiness Church on the Ridge that Mattie Ruth Johnson describes in My Melungeon Heritage. The practices of these two churches were apparent at the Vardy Presbyterian Church or at the Vardy Community School when some who joined the Presbyterian church insisted on being baptized by immersion and at other times when the snake-handling at the Holiness Church either raised questions or was the cause of illness or even death to a person who was bitten by either rattler or copperhead.
} 
her mother care for younger siblings and in so doing began to realize her vocation to work with children. She attended Macalester Presbyterian College in St. Paul and after graduation in 1903 very deliberately chose to become a Presbyterian mission worker in the southern mountains. She believed that her life to that point had prepared her for such service. Her first assignment was a small mining town on the Cumberland Plateau called Ozone. Rankin taught there for three years before leaving to pursue a Master's Degree at Columbia in New York City.

As a registered nurse and experienced teacher, she received her second and final assignment in 1910. According to David Swartz, a Presbyterian minister who served at Vardy as a Union Seminary Intern during the 1940s and later as an administrator at the Board of National Missions, Rankin had written on her application for mission work, "I believe that God has called me to the Mountaineers and has been specially preparing me throughout my whole life for work among them. ... [My work is] the giving of Christian education with the vocational training that will fit our young people for happier, more useful life elsewhere if they should desire to leave. ${ }^{38}$

Miss Rankin's nursing was a critical part of her ministry. The nearest doctor was over twenty miles from Vardy and virtually inaccessible. To mitigate that circumstance, Rankin enacted visible literacy practice over and over as she read medical journals and stayed in contact with the physician her family had used back in Minnesota. She would write to ask him questions and follow his step-by-step instructions on various procedures she received by return mail. According to an article in Vardy Voice by Jim Callahan, one of Miss Rankin's early victories was eradicating hookworms and roundworms among the

\footnotetext{
${ }^{38}$ DruAnna Overbay, Windows on the Past, 34.
} 
children. When they refused to take the medicine she had ordered, she demonstrated taking the medication herself and won the children over. ${ }^{39}$ Miss Rankin's reputation as a healer grew to such proportions that a doctor came from Johns Hopkins to study her methods and her results. She also gave immunizations against smallpox and diphtheria. Rankin's selfless devotion is shown by the fact that she used part of her small salary for medical supplies. Callahan notes that she said, "It was my job to do that. . . they trusted me. They didn't have anyone else. ${ }^{, 40}$

Miss Rankin was also a midwife and delivered many babies in the community. Margaret Williams Nevels recalled, "When and wherever she was needed, she worked as a nurse and midwife to the community. In fact, she delivered me because I came into this world before Dad had time to get the doctor. We had no telephones in 1937 anywhere in the community. She would go into the homes to teach people sanitary methods of caring for the sick and how to prevent the spread of disease."41 Mary Rankin's "kit" is preserved in the Vardy Church Museum; it consists of a leather medical bag and an assortment of white enamelware vessels — basins, kettles for boiling water, a bedside tray, and a teapot. The story goes that she would come to care for those who needed her ministrations and then would leave the equipment for the family to use until the time of sickness was over.

\footnotetext{
${ }^{39}$ Jim Callahan, "Miss Mary J. Rankin,” Vardy Voice, December 2002, 8-9.

${ }^{40}$ Callahan, "Miss Mary J. Rankin," 9.

${ }^{41}$ Margaret Williams Nevels, Oral History Interview, quoted in Windows on the Past, 35.
} 


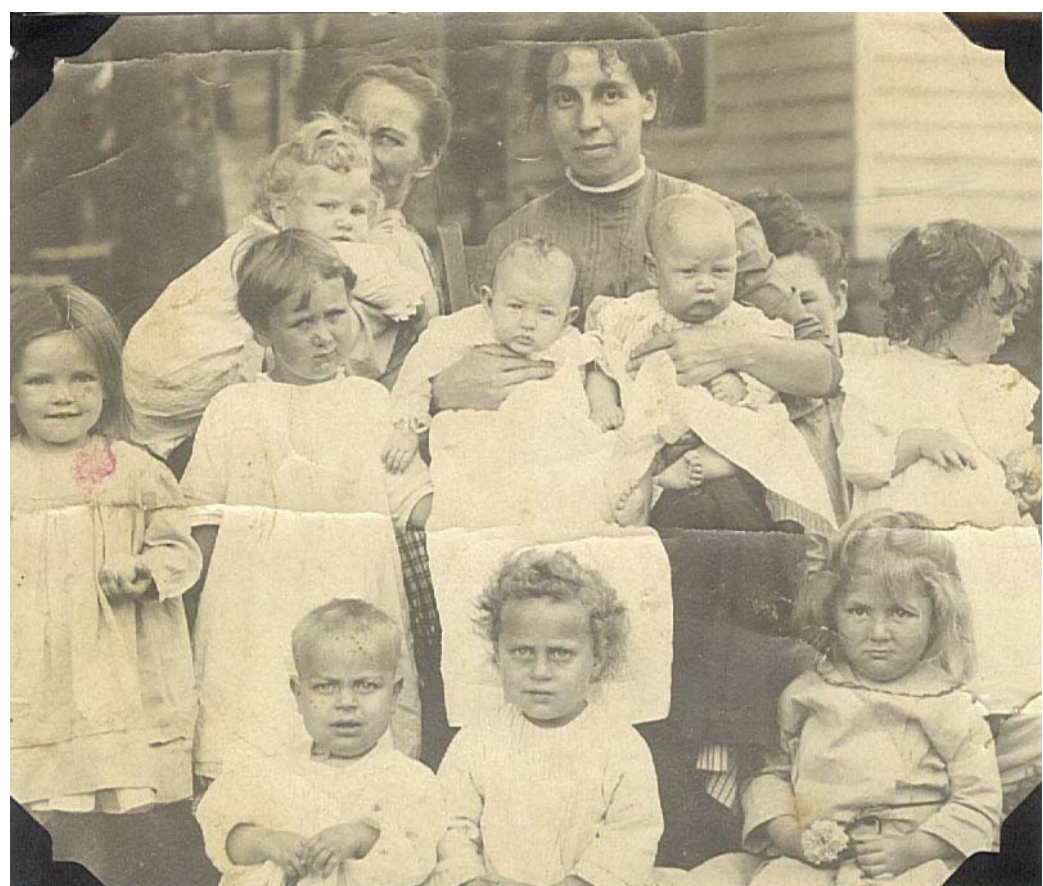

Mary Rankin, center, with some of the babies she delivered. Isabelle Horton, the smaller baby on Rankin's lap is the daughter of Adelaide Collins Horton and Dan Horton, granddaughter of Batey Collins, on her baptism day.

\section{Charles Sizemore,}

a participant in the oral

history project, said,

"Coming here as a young

woman and staying until

she was an old lady

illustrates that she

dedicated her life to the

people in the community.

As I look back on it, she was one of the most

important persons in my life other than close family. She was my teacher from primer through second grade." ${ }^{42}$ As Sizemore clearly remembers, Miss Rankin was a teacher as well as a nurse. At the time of the first missionary teachers' arrival, there was a log cabin school in Vardy. Will Allen Dromgoole, who lived with the Calloway Collins family on the Ridge to gather material for her Arena articles $\left(1891^{43}\right)$, has little good to say about that school or the Melungeons' literacy:

They are exceedingly illiterate none of them being able to read. I found one school among them, taught by an old Malungeon, whose literary accomplishments amounted to a meager knowledge of the alphabet and the spelling of words. Yet,

\footnotetext{
${ }^{42}$ Charles Sizemore, Oral History Interview, quoted in Windows on the Past, 34.

${ }^{43}$ Dromgoole, "The Malungeons," 477.
} 
he was very earnest, and called lustily to the "chillering" to "spry up" and to

"learn the book." 44

By the time "sky-pilot" Christopher Humble got to Vardy in 1897, Batey Collins' son Noah, described as being "swarthy like his father," was the teacher. I doubt Noah Collins would have been Dromgoole's "old man," since he was only 30 at the time of the missionary's visit. Humble had a discussion with Noah about the name "Melungeon." Humble reports in his article that Noah Collins resented being called Melungeon, saying, “"We are a pure blood people,' meaning at least that they had no Negro blood in their veins. ${ }^{45}$

Ruth Muhlbauer, another contributor to the oral history project, recounted her family's participation in the literacy education of Vardy residents before the Presbyterians arrived: "I remember my mommy telling me that the Presbyterians sent missionaries who taught during the school year and then would go back to their respective communities during the summer. She went to school in the first schoolhouse and then later in the second schoolhouse. My grandfather Leham Miser taught school in the log schoolhouse, which only went through the sixth grade. ${ }^{\$ 46}$

In 1902, the Presbyterians paid to build a school that was state of the art for its time. Danny Turnmire quotes a newspaper article by Vardy historian Bill Grohse to describe the new 1902 school:

\footnotetext{
${ }^{44}$ Jack Goins speculates that this old teacher was George Washington Goins and that the school Dromgoole visited was not in the Vardy valley but instead closer to the Clinch River.

${ }^{45}$ Humble, "A Visit to the Melungeons," 244.

${ }^{46}$ Ruth Jenkins Muhlbauer, Oral History Interview, quoted in Windows on the Past, 86.
} 


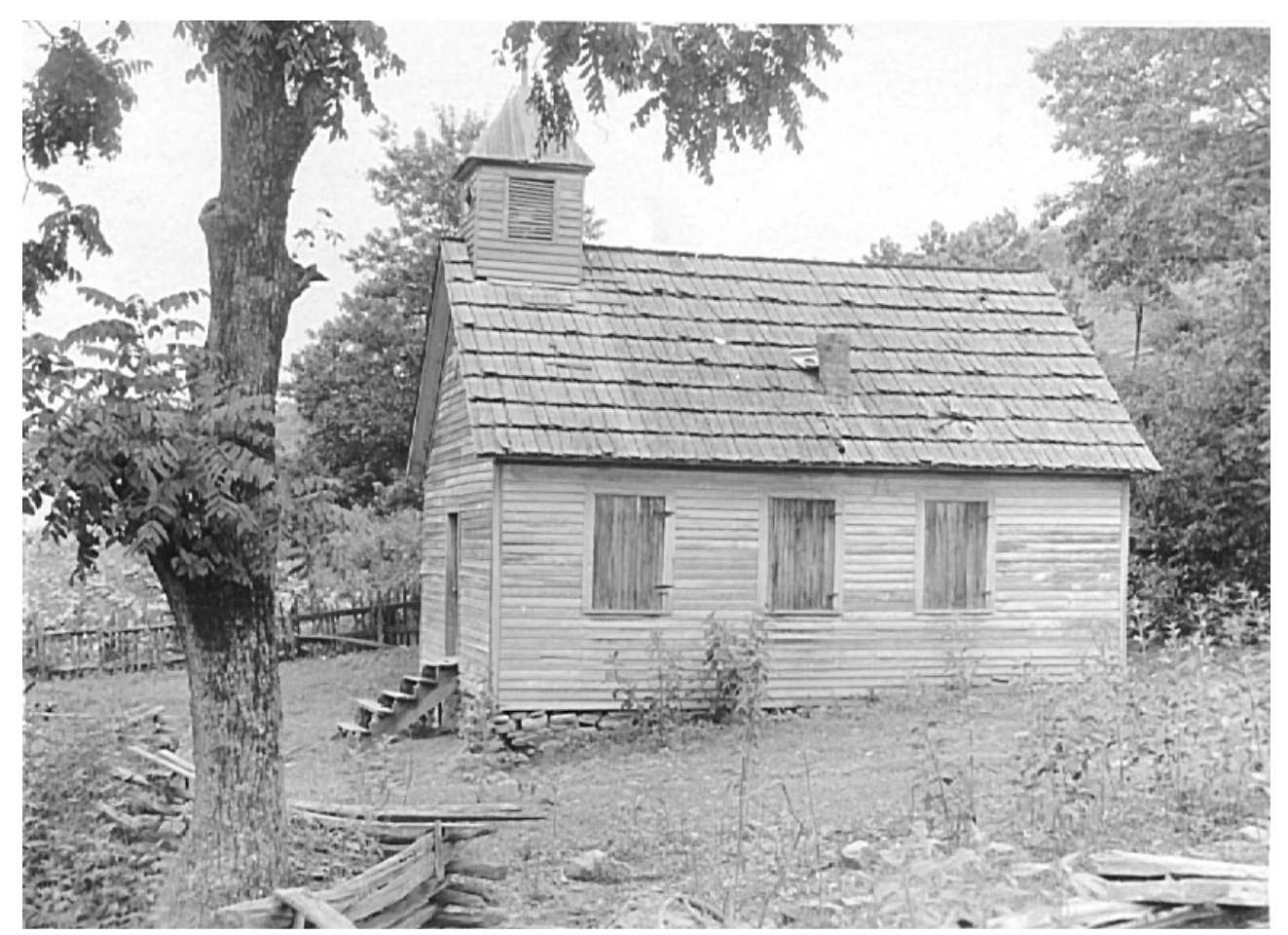

This picture shows the 1902 school, a vast improvement over the log cabin previously used.

The first clapboard schoolhouse at Vardy was built by money secured through the Woman's Association of the Presbyterian Church, U. S. A. Teachers were provided by the Church. The building was a small 26 x 20 one-room frame structure with three windows on both sides, and blackboards of all four sides where space permitted. It had large double doors at one end to emit the "surgin' children.” In 1902 there were 25 students; by 1913 there were 65 . The curriculum included agriculture, industrial arts, and homemaking along with basic studies and preparatory courses. $^{47}$

Bill Grohse, in several unpublished "histories" of education in Vardy, adds more details about the school building and Miss Rankin. He notes that the floor of the building was double and supported by $2 \times 12$ joists to accommodate heavy student traffic and that

\footnotetext{
${ }^{47}$ Danny Turnmire, "Education of the Melungeons," 22-23.
} 
the walls and ceilings were made of tongue and grooved lumber. There was a platform at the rear of the building; a heavy school bell in a bell tower called the students to their classes.

As mentioned previously, the frame teachers' cottage was built in 1920 immediately west of the church. It had a gable roof and windows that extended out from the walls. Behind the house was a log cabin used by Miss Rankin for storage (could this have been the cabin Margaret McCall detailed in her description of her first year in Vardy?). This earlier mission house (shown on page 112) was decimated by the strong tornado that devastated the Vardy valley in 1933, destroying in addition the old Batey Collins boarding house further west.

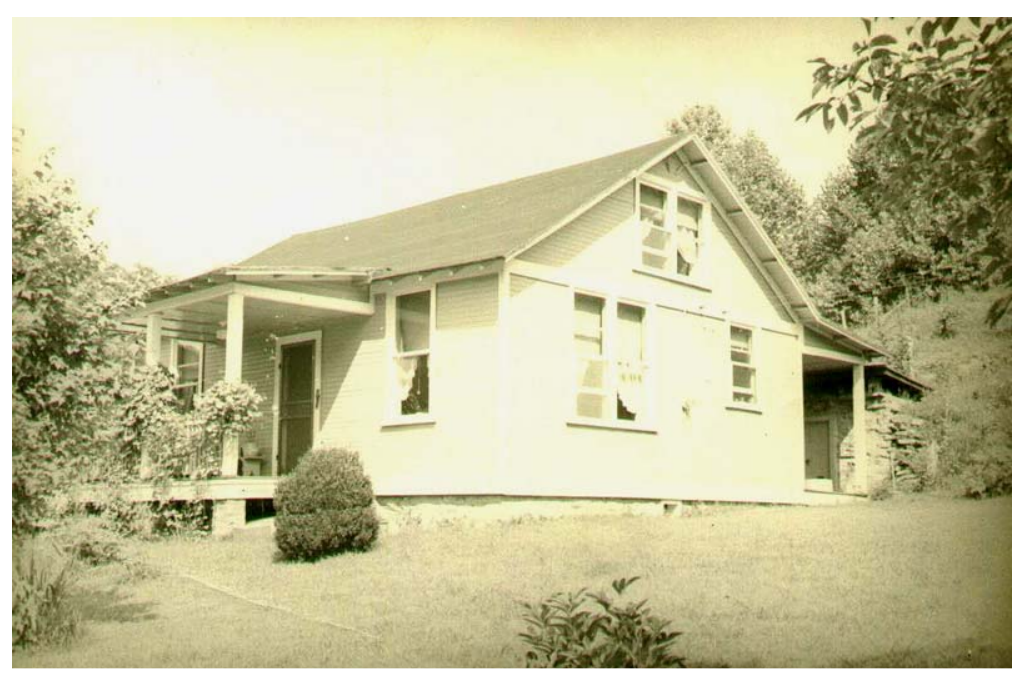

The Rankin Cottage built after the 1933 tornado still stands today.
When the house that became known as the Rankin Cottage was built after the tornado, it was made to look more like the other campus buildings. This house, now on the National Register of

Historic Places, has four rooms, living room, kitchen, and two bedrooms. The attic was big enough for six to eight guests to sleep on rollaway cots. Miss Rankin did not enjoy any indoor plumbing; she used the outdoor toilets behind the church. 
Rankin was a sponsor of literacy whose concern and care for the community residents was legendary. ${ }^{48}$ In her early years in the valley, she was so popular as a teacher that children from neighboring one-room school districts begged to be able to come to her at Vardy. To accommodate the influx, the Hancock County Board of Education agreed to pay her $\$ 25.00$ per month and to give her one box of crayons and $\$ 6.00$ for supplies. Rankin saw that the need for longer school terms was imperative, so she offered two additional months of school asking that the families pay twenty-five cents per pupil per

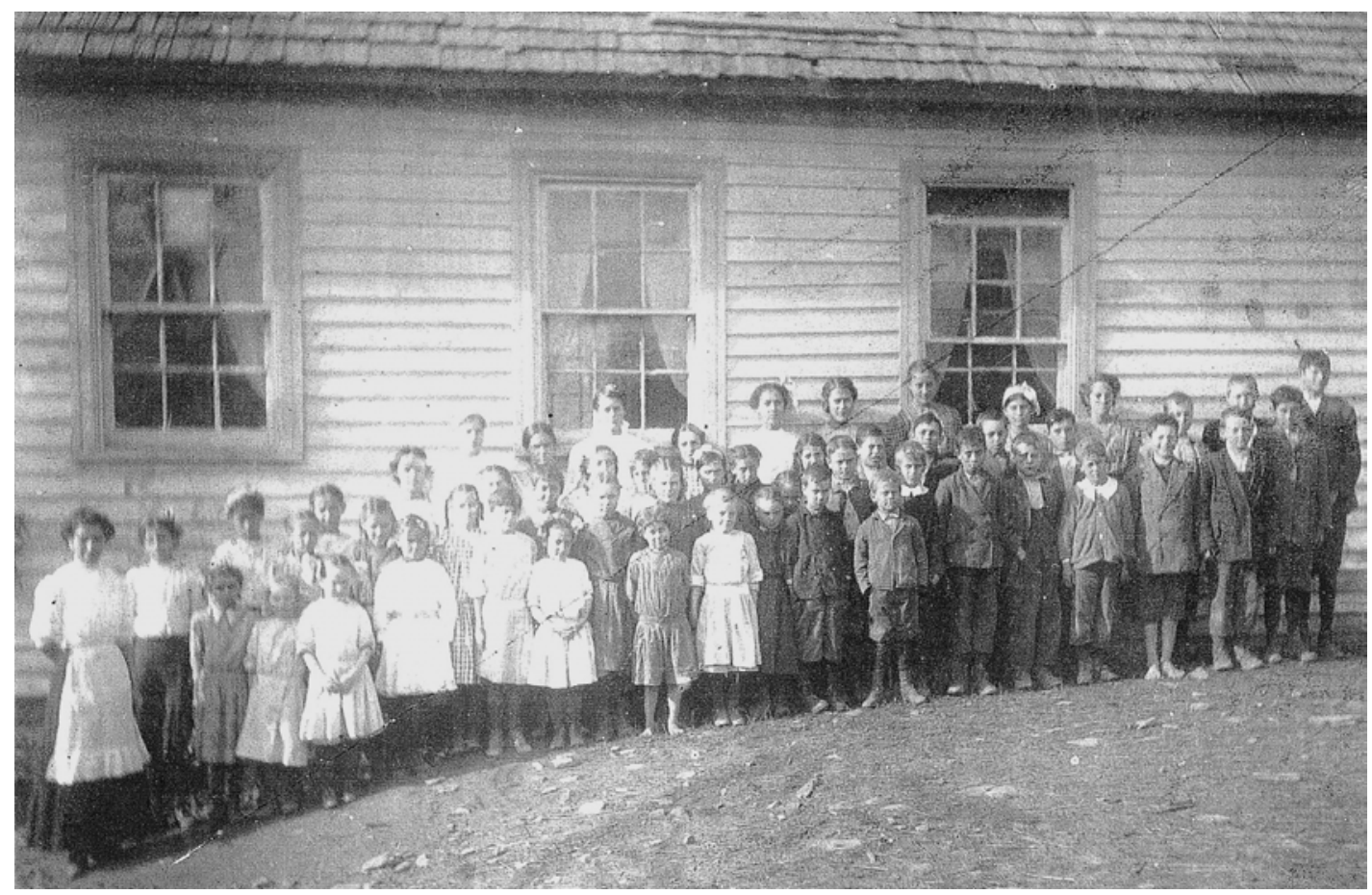

This old photo shows Mary Rankin with 52 students beside the 1902 school. Between 1910 and 1920

month. If parents couldn't afford the fee, she allowed them to "work it out" in various ways. Miss Rankin also was in charge of the barrels of donated clothing that would arrive periodically from churches in New York and New Jersey. Several of the participants in the oral history project recounted their forays to Miss Rankin's attic: "People up north

\footnotetext{
${ }^{48}$ William Grohse, "Vardy: Claiborne County Community Remembers Its Heritage of Mountainmen, Moonshine," Citizen Tribune, 19 January 1986, C1.
} 
would send clothes to her which she would divide among the children. She made decisions of who needed them the most because we had no money." ${ }^{49}$

In the first years of her tenure, Rankin taught school to grades 1-8 during the week and then "preached" Sunday school to both the children and the adults on Sundays. Another kind of teaching was the night school she held for adults in the community. They came to learn reading and writing and to hear about the latest agricultural methods. They paid for this literacy instruction with foodstuffs and maintenance of her house.

Mary Rankin was zealous for the well-being of her students in every respect. Margaret Williams Nevels remembers Rankin's concern for her spiritual health, "When I was 12 years old, Miss Rankin asked me to come to her cottage where she discussed the importance of my accepting Jesus as my Savior and the importance of being baptized. She taught Sunday school classes and read Bible stories to us and related the importance of each story to our lives. ${ }^{, 50}$ Mary Rankin quickly realized that she was not capable of providing every academic opportunity her students needed — how could she? One teacher managing 65 students in one schoolroom? Aware of the broader scope of the Presbyterian Church's mission efforts in the mountains, she encouraged parents of promising students to send them to the Presbyterian boarding schools in the Asheville, North Carolina vicinity.

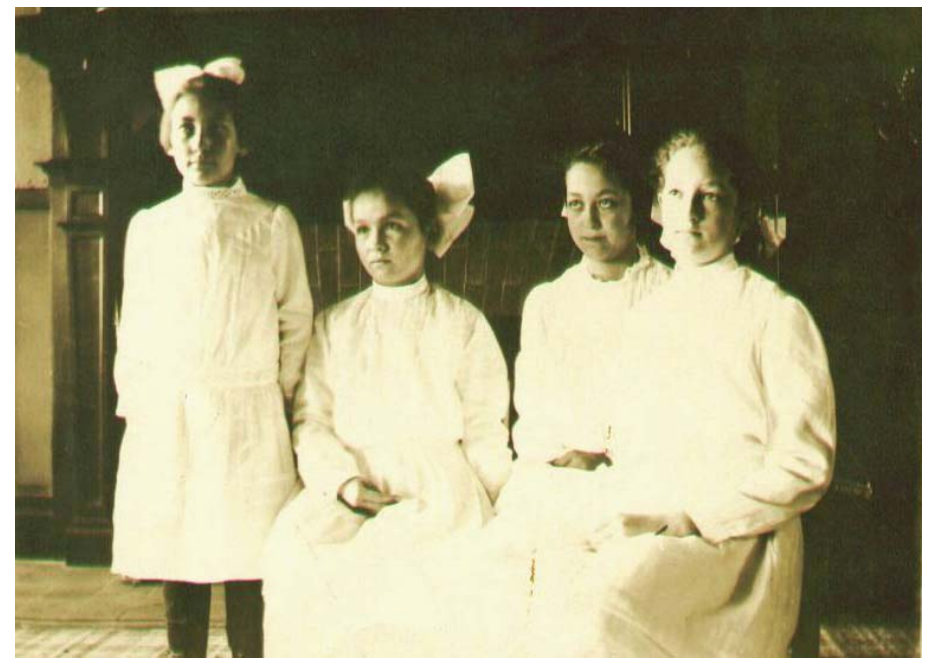

Vardy girls at the Pease Home School in Asheville, North Carolina.

\footnotetext{
${ }^{49}$ Ruth Jenkins Muhlbauer, Oral History Interview, quoted in Windows on the Past, 34.

${ }^{50}$ Margaret Williams Nevels, Oral History Interview, quoted in Windows on the Past, 36.
} 
The Pease Home School was begun in 1887 by Rev. and Mrs. L.M. Pease, retired Methodist missionaries when they opened a school in their home as an outreach to orphaned and underprivileged mountain girls. Their school became a part of the Home Industrial School in Asheville. Another couple, Rev. and Mrs. Luke Dorland, former missionaries with the Freedmen's Bureau in the North Carolina Piedmont, also started a school in their home that became Dorland Institute. The Presbyterian Board of National Missions took over both of these schools. Pictures of Vardy children in attendance at these schools demonstrate not only Miss Rankin's determination that her students should have the best educations she could provide, but also that some parents in the valley saw the need for and benefits of formal schooling for their children. The Pease School took girls as young as seven; it's hard to imagine such young children leaving their isolated valley to catch the train at Ben Hur, Virginia, and make the trip to Asheville.

These boarding schools for mountain children stressed a traditional curriculum as well as work. Students did the cleaning, cooking, laundry, and outdoor tasks that kept the schools going. The third component was Christian instruction: daily Bible study, prayers and singing before and after meals, Wednesday night and Sunday services. The centennial history of Warren Wilson College, the descendant of the Asheville complex of mountain schools, proclaims, "Presbyterian officials and teachers firmly believed that development of these three aspects of their program - 'in proper relationship' to each other-would nurture practicality and virtue and prepare young people for responsible lives, the major end of a mission school education." ${ }^{51}$ The Asheville Farm School for boys opened in 1894. It, too, was under the Presbyterian Mission umbrella: "Farm

\footnotetext{
${ }^{51}$ Mark T. Banker, Warren Wilson College: A Centennial Portrait (Swannanoa, NC: Warren Wilson College, 1994), 10.
} 
School's 'boys' were in fact mostly men in their teens and twenties, who were eager to pursue an education made affordable through their own labor.... Book learning at the Farm School initially meant the "three R's," but by the early 1900s many students completed the equivalent of an eighth-grade education.... [I]n 1924 the first high school class graduated." 52

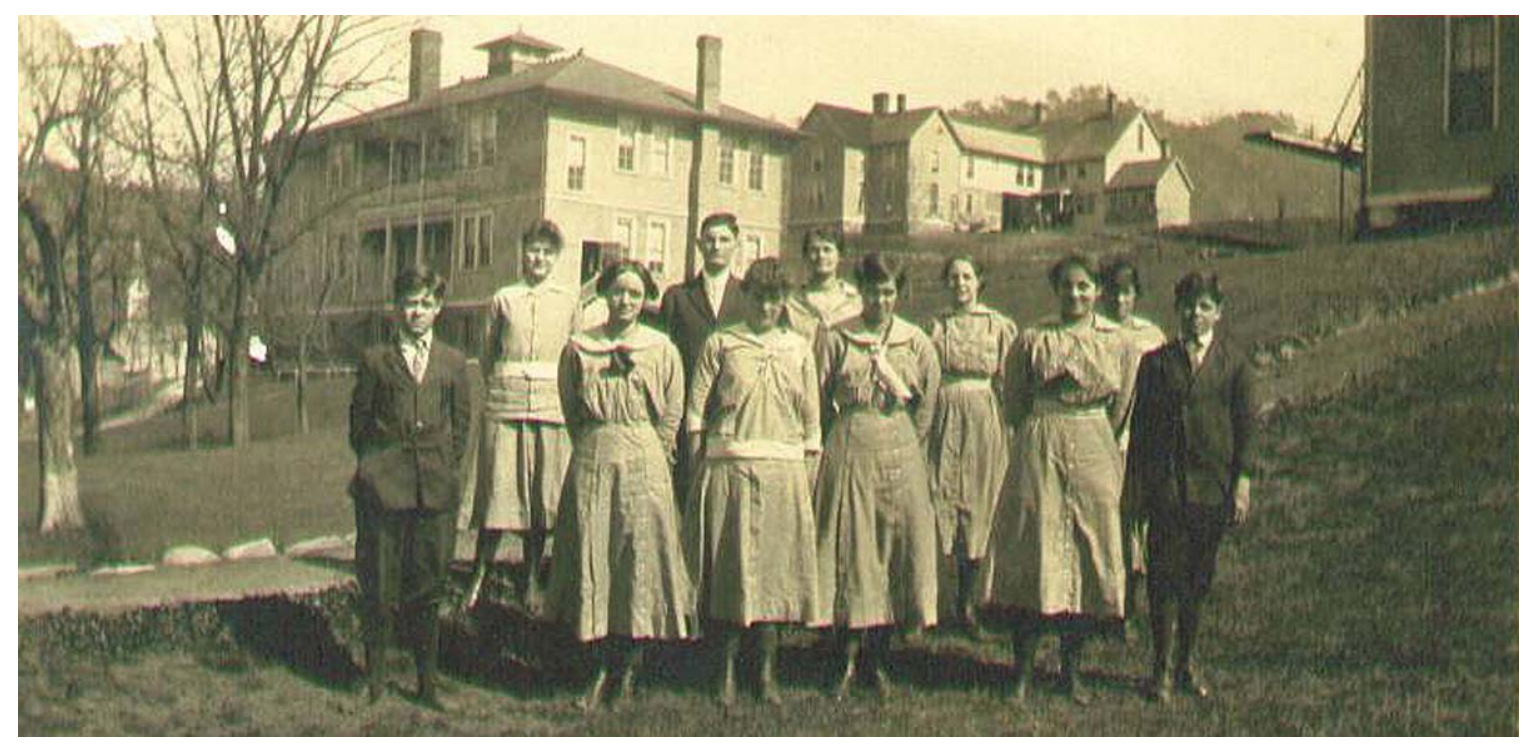

Vardy girls and boys pose on the lawn at Dorland Institute near Asheville, North Carolina, many miles from home.

Grohse, ${ }^{53}$ a later mediator of literacy in the valley who was a friend of Oppie Miser, one of the Vardy boys who went off to World War I, writes in one of his typed overviews of the history of Vardy that the Presbyterian missionaries taught the people the benefits of education. In a newspaper article, he says, "Many of todays [sic] successful business and professional people owe Miss Rankin a debt of gratitude for her untiring efforts in their behalf. ... [She and Rev. Leonard] sent many of the children to

\footnotetext{
${ }^{52}$ Mark Banker, Warren Wilson Centennial Portrait, 11.

${ }^{53}$ Grohse married Lillian Miser, daughter of Nancy Collins Miser and Logan Miser. Grohse and Lillian stayed in Vardy, farming the family land and running a small general store. Grohse eventually moved his German immigrant parents to Vardy as well. He gradually became the "authority" on local history and genealogy; he collected many historical documents and family records that now are the property of Mrs. Johnnie Clyde Rhea.
} 
Presbyterian Schools in North Carolina and elsewhere so that they could be better prepared for life's problems." ${ }^{.54}$ Rankin, in both overt and subtle ways, sponsored the people of Vardy as they acquired literacy skills and prepared to take their places in the broader societies of the region and the nation.

The establishment of the Vardy Community Center that resulted in monumental changes for Vardy residents, who were Melungeon descendants, happened because a number of forces came together with precision. Philosophical and theological ideas such as Darwinism, the Christian America Movement, and the Social Gospel initiatives were factors. Even though Vardy had no coal and only lumber to sell to the industrial complex, economic pressures and the imperatives of late nineteenth and early twentieth century capitalism were factors. Increasing demand for a reading and writing citizenry dictated educational objectives and literacy goals. And, various personal initiatives by remarkable people such as Batey Collins, Christopher Humble, and Mary Rankin made the Vardy experiment prosper where other similar efforts foundered or failed. These dynamic forces coalesced in this very small and isolated community. Vardy was moving into the mainstream of twentieth century. Things had changed dramatically by 1920 , a year when some mountain work was already being abandoned. However, the glory years of the Vardy experiment lay ahead; the arrival of Chester F. Leonard, the first, last, and only minister the Vardy Presbyterian Church and Community Center would have made the Vardy mission not only successful but unique in the canon of the mountain work, and inestimably valuable for the Newman's Ridge Melungeons.

\footnotetext{
${ }^{54}$ William Grohse, "History of Education Vardy-Newman's Ridge Area," (this article was clipped from its source. Neither the name of the newspaper or the date are noted on the clipping. Internal evidence puts the writing in the late 1960s or early 1970s because of the note about the consolidation efforts by the State of Tennessee. The statements about Miss Louise Avery being a teacher at Vardy and Rev. Arnold Johnson being the principal are also clues that date the piece.)
} 


\section{Chapter 4}

\section{Chester Leonard: Going Beyond the Basic Blueprint}

\section{CHAPTER INTRODUCTION}

Hancock County Melungeon families of a century ago lived in a culture of subsistence poverty, physical hardship, strong religion, imminent violence, and racial shame. Will Allen Dromgoole's descriptions, though despised by the Melungeons themselves, show how she perceived life among the Melungeons on Newman's Ridge. Wrote Dromgoole, "They live from hand to mouth and in hovels too filthy for any human being. . . . A tobacco patch and an orchard is the end and aim of their aspirations. ... They are all distillers: that is, the work of distilling is not confined to the men. Indeed, the women are the burden-bearers in every sense. They cook, wash, dig, hoe, cut wood, gather the fruit, strip the tobacco and help with the stills."1 The history of discrimination in custom and in law meant that Melungeons could not enjoy even those advantages other mountaineers took for granted, such as access to whatever medical care a locality boasted, to schools when schools existed, and to the ballot box. Mary Rankin, the tireless Presbyterian mission worker, and Pastor Chester Leonard, who came to Vardy twenty years after the

\footnotetext{
${ }^{1}$ Will Allen Dromgoole, "Land of the Malungeons," Nashville Sunday American, 31 August 1890, at http://www.melungeon.org/?BISKIT=2206291721\&CONTEXT=cat\&cat=10014, accessed 27 February 2005.
} 
mission's founding, had to confront head on not only the challenging conditions but also the blatant racism.

The last century has brought many changes to Appalachia. One significant change is the emergence of the "Melungeon Movement." People with Melungeon heritage are now even calling themselves "Melungeons," exploring their heritage through many avenues, inviting scholarly investigation of their past and present, and publishing their findings and their thinking on the Internet.

How the Melungeons gained literacy as well as how they have used and are using literacy shows some important traits they share. Their thinking about themselves is permeated with an awareness of their racial difference. Most of the dialog either tries to explain what the difference means or show its effect. One contemporary theorist that helps outsiders understand both the Melungeons' racial shame and the story of their acquisition of literacy is bell hooks. In her writing, hooks examines what race means for the process a group of people must go through to understand themselves. For hooks, education is central to this process. Furthermore, hooks says that education can only flourish in a community. A carefully crafted community, that fosters both selfunderstanding and learning, helps its members deal with their racial shame. These ideas make hooks's theory and pedagogy especially applicable to a study of the Melungeons.

Chester Leonard, the hero of this chapter, was not a Melungeon, but he spent his entire working life among them. Some of the secrets of his remarkable success lay in the ideas and mentors he was exposed to during his years of preparation in college and seminary. Important theorists that he would have encountered include John Dewey, Maria Montessori, and Walter Rauschenbusch. Dewey's Democracy and Education laid 
out a new pedagogy designed to challenge American citizens to be full participants in the life of the body politic. Dewey also advocated applying the scientific method to curriculum design and school administration.

Montessori championed a child-centered pedagogy that allowed children to be led by their own curiosity in a school setting. She also recommended that classroom furniture be child-sized and that the school become involved in many areas of children's lives, such as nutrition, health practices, physical exercise, and cleanliness. Many of these things are commonplaces today; we forget that one-room schools in Appalachia a century ago had only backless benches for furniture and one teacher who served all the children from first grade through eighth grade. The curriculum and pedagogy of these one-room schools were rigid.

Walter Raushenbusch's social gospel theology was as revolutionary in the mainline Protestant denominations as Dewey's theories and pedagogies were in education. Even though Rauschenbusch was creating a scenario of ministry to urban factory workers, the poverty and hopelessness in city ghettos was similar to conditions in isolated mountain valleys. Ideas, practices, and even patterns of language from these three contemporaries of Leonard's are evident in what he did as well as in his writings about the Vardy Presbyterian Center.

Leonard could have failed. Some of the settlement schools and the missions were abandoned early, but not Vardy. Leonard was an unusual human being who made his ambitious dream into an impressive reality. His determination transformed the place and two generations of Vardy students. Undaunted by poverty, illiteracy, hardship, racism, and violence, he intentionally forged a strong community that gave the Melungeon 
children the skills and the will to confront the stigma of race and to grab success in Appalachia and beyond.

\section{THE BEGINNING AT MARYVILLE COLLEGE}

Two men significant in this saga of Melungeon literacy may have met at Maryville as early as 1913. The first was Samuel Tyndale Wilson, the college president. Wilson's heart was in the Home Missions work in Appalachia. His book, The Southern Mountaineers was most likely in process, since it was published in 1914. As detailed in my last chapter, Wilson's book delineates the philosophy and programs of the mountain "uplift" work undertaken by the Presbyterians. In addition, he includes tables listing the names of individual mountain missions, how many students they served, and how many missionaries staffed each one. In 1914, the entry for the Vardy Mission at Sneedville, Tennessee, shows one mission teacher/worker (Mary Rankin), property valued at $\$ 761$ (the church, school, and a house for missionary women), and 25 industrial pupils. ${ }^{2}$ This information reveals that the Vardy work was a small operation compared with other efforts in the region.

Although nothing in print says that Samuel Wilson was a key player in the Vardy effort, I believe that he was. As president at Maryville, he must have soon become aware of a serious young pre-ministerial student named Chester Fred Leonard. Leonard, born February 19, 1892, in Birmingham, Alabama, attended high school in Wisconsin. He worked for two years as an apprentice mechanic for the Chicago Brass Company of Kenosha; by his $21^{\text {st }}$ birthday, he had worked as a mechanic and had sold mattresses. Not

\footnotetext{
${ }^{2}$ Samuel Wilson, The Southern Mountaineers, New York: Presbyterian Home Missions, 1914, 199.
} 
having a high school diploma, he applied and was accepted as a conditional freshman at Maryville in 1913. The records verify that Leonard excelled academically in college, graduating magna cum laude. The yearbook shows he was an officer of the students' Ministerial Association.

I do not doubt that Samuel Wilson was encouraging Maryville students to familiarize themselves with the Presbyterian Mission efforts in the Appalachian region. Chester Leonard apparently responded with enthusiasm. Dave Swartz, who served as a seminary intern under Leonard at Vardy in 1946-47, reported, "He had spent a summer with Ms. Rankin in Vardy before completing his senior year at Maryville. There was need for pastoral leadership and the improvement of educational opportunities for the children. Mr. Leonard was challenged. He was confident that he could work slowly with the families to achieve mutually determined goals and a few that only he determined!”3 A letter he wrote outlines his plan to spend the summer of 1918 in Hancock County, and Session meeting minutes of the Vardy Presbyterian Church record Leonard's presence in Vardy on August 10, 1918.

Besides this kindling of interest in mission work as a vocation and in the Vardy mission as a location, another passion began to burn for Leonard during his years at Maryville; he met and fell in love with a fellow student from Birmingham, Alabama, Miss Josephine Wicks. In the fall of 1917, after his college graduation, Leonard enrolled at McCormick Theological Seminary in Chicago. On December 25, 1918, in the middle of his seminary studies, he married Josephine.

\footnotetext{
${ }^{3}$ David Swartz, Email message to Katherine Vande Brake, 25 October, 2003.
} 
Mrs. Leonard took a year of kindergarten training while they were in Chicago, ${ }^{4}$ but I cannot say for certain what Leonard studied at McCormick. However, my best guess is that he encountered two scholars that challenged him. With a pull toward the work at Vardy already in his mind, it appears that the social gospel theology of Walter Rauschenbusch $^{5}$ and the educational philosophy of John Dewey ${ }^{6}$ shaped Leonard's thinking and helped him formulate some plans as he looked ahead to his life's work.

\section{LEONARD ARRIVES IN VARDY}

A significant entry in the Church Minutes for May 5, 1920, is in Leonard's own handwriting and states, " C.F. Leonard entered upon the work assigned to him by the department of Country Life of the Presbyterian Church in the U.S.A. at Vardy under the Presby. of Holston, Synod of Tennessee." ${ }^{7}$ According to Swartz, who worked for the Board of National Missions in New York where he had access to all of Leonard's records, Leonard signed a contract with the Board of Home Missions to serve as the pastor of a Demonstration Parish Plan for a

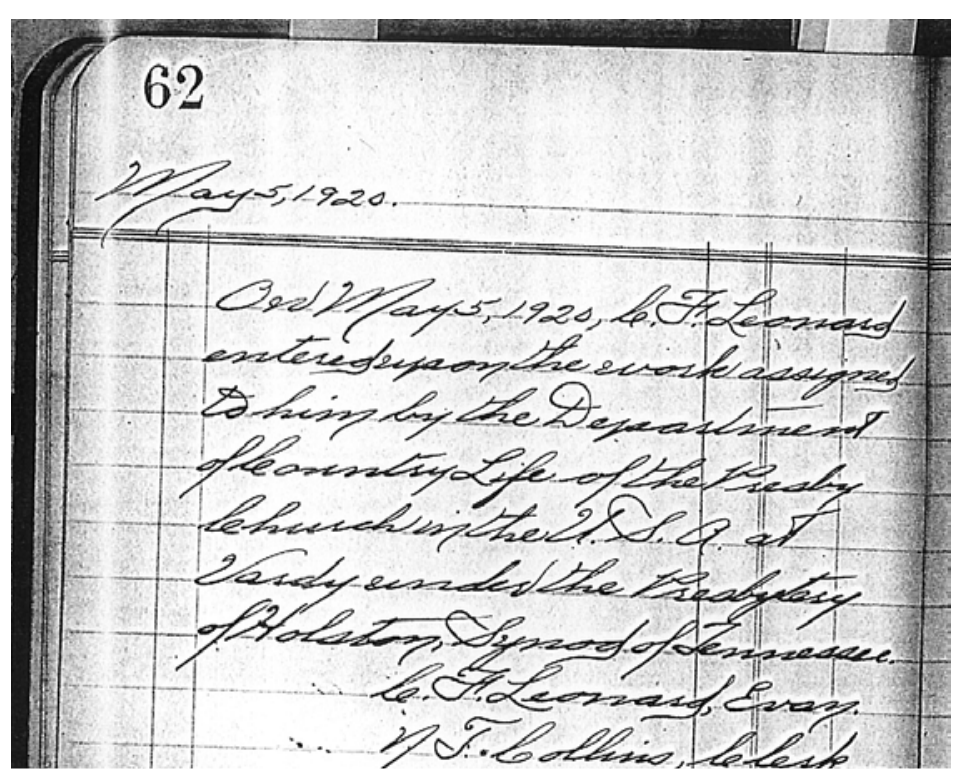

Leonard's first entry in the Vardy Church session Record in May 1920.

\footnotetext{
${ }^{4}$ Chester Leonard to Josephine Wicks, Letter, Windows on the Past $2^{\text {nd }}$ ed. by Druanna Overbay, Appendix, forthcoming.

${ }^{5}$ Christianity and the Social Crisis, 1907.

${ }^{6}$ Democracy and Education, 1916.

${ }^{7}$ Vardy Presbyterian Church Record Book \#1, 1902-1935.
} 
seven-year term. Terms of this contractt stated, "Vardy shall provisionally concern itself, besides evangelism and worship, with rural schools, good roads, public health improvement, recreation and economic betterment of all who dwell in the community."

One of the first things Leonard did in Vardy was build a new manse to replace the original parsonage that had been destroyed by a fire. Wrote Leonard, "We needed a manse. Our people had no money. The board loaned us two thousand dollars. The men offered teams, labor, and equipment. We went to work. Because there were no carpenters, we bought a ready-cut house pattern, hauled it twenty-five miles over mountain roads and erected a house in the hills. The trip for each load took two days; one day to go and load up and one to return. The "preacher" made every trip, did his share of the loading, cooked, and helped with the work." "This project shows his ability to bring people in the Vardy community together to accomplish something corporately that they never could have done individually; it demonstrates his charisma as a leader.

The house had a recessed portico in front setting off a dark wood doorway with a transom and sidelights. There was a living room, a dining room, a kitchen, and two bedrooms on either side of a connecting bath. The bathroom, no doubt a wonder to Vardy residents, had an enameled tub with ball-and-claw feet, a toilet that had a water tank mounted high on the wall above the bowl, and a large sink with hot and cold running water mounted on another wall. There was beaded-board paneling as wainscoting and a recessed mirrored medicine cabinet above the sink. The interior walls of the house were of pressed board wall-papered throughout the rooms. The hardwood floors were brightly

\footnotetext{
${ }^{8}$ DruAnna Overbay, Windows on the Past, 42.

${ }^{9}$ Chester F. Leonard, "Helping a Community to Help Itself: A Story of Christian Cooperation and Expanding Vision That Follows the Gospel in the Mountains," Presbyterian Advance, 18 October 1928, 10.
} 
varnished. As the years went on the boys from the manual training classes at the school built a corner cupboard in the dining room, cupboards in the kitchen, a large bookcase in the living room, and a long window seat under one set of the living room's double windows.

The house was comfortable in the early 1920s and still is. I have stayed there with DruAnna Williams Overbay and her husband Fred, the current owners; many of the furnishings are pieces and decorations that belonged to the Leonards during their time in Vardy. I feel the weight of history when I sleep in Josephine Leonard's bedroom under a picture of Oriental poppies that hung over her bed and when I wake up to see Mrs.

Leonard's oak washstand against the wall and face the wooded summit of Newman's Ridge out the window.

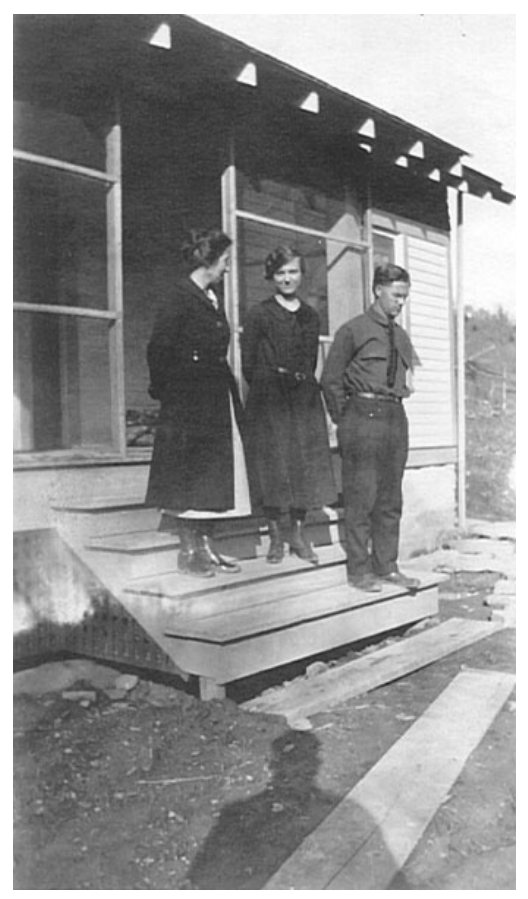

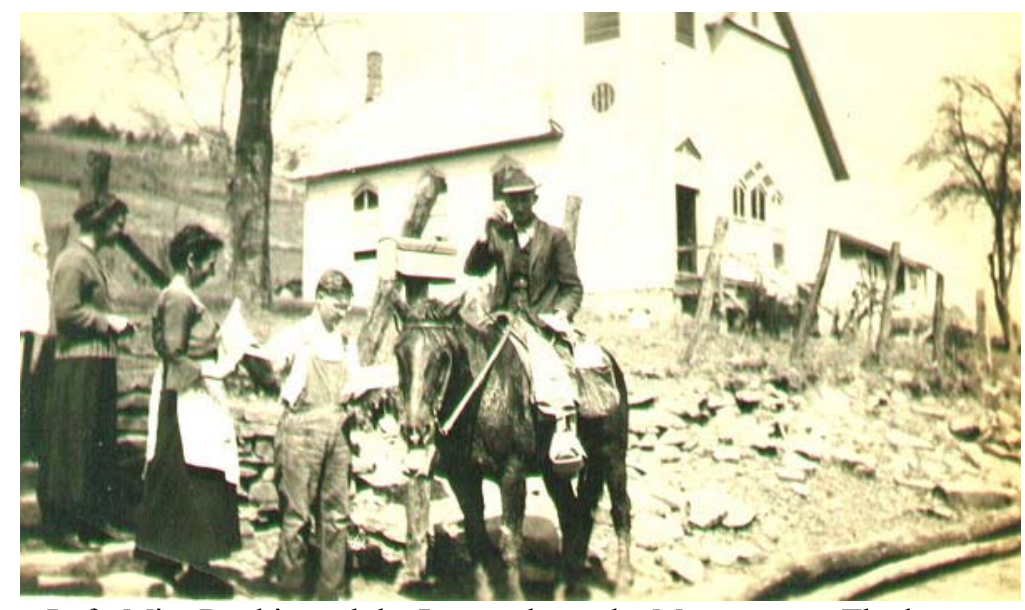

Left: Miss Rankin and the Leonards on the Manse steps. The house must have been very new; no grass is growing in the yard. Above: The missionaries getting their mail in front of Miss Rankin's cottage. Church and manse are in the background.

His early visits to Hancock County and possible conversations with Samuel Wilson may have led Leonard to believe that he understood the situation at Vardy. After he arrived at the Presbyterian Center, talking with Mary 
Rankin and hearing of her allegiance to the principles of Maria Montessori's revolutionary methods of pre-school and primer education must have only added fuel to the fire of Leonard's enthusiasm for what would be his life's work. However, there was a reality he and Rankin, and Wilson for that matter, were seemingly unaware of. None of them really understood the mountain religion of the people they had pledged to help. They were certainly aware of mountain churches and religious practices. And, they knew members of those churches, but their methods and the program they put in place reveal that they understood neither the beliefs nor the implications of those beliefs for the success or failure of the Vardy mission.

An interesting unsigned letter, obviously written by a mission worker in July, 1916, excerpted below, is addressed to a sister of the writer named Addie Arthur:

The Holiness people here practice "speaking with tongues" and a jerking that is like dancing, I guess, when it is in their feet. I wanted to see it, not to make fun, but to be instructed. . . . Last Friday while visiting on the Ridge, I went to George Gibson's, one of the Holiness members. ... [W]e sang some of their Holiness songs. I can make a shift at singing most any simple music, and got along fairly well. Suddenly I heard a peculiar noise behind me, and startled, turned around. One of the girls, a young woman, hearing the religeous [sic] music, had been carried away and was having the "Jerks." I had read of them in the history, but never saw it before. It is just the natural old-fashioned "jerks" such as the folks used to have in the first Camp Meeting times. And she jabbered incessantly, seeming to speak words, but not English. It sounded much like any foreigner talking rapidly. __ (torn paper) acted like one having the St.Vitus 
Dance, jerking with the upper part of her body, but little or none with her feet. I was surprised, and a little frightened. ... The Folks explained to me, that that was the dancing as the sinners around call it, that had it worked in her feet too, she would have danced as they say. She felt somewhat ashamed of it, because I was here and tried to hold it down, but "the Lord was stronger than she." It can't be "Holped" (helped) the man said. Several of their family have that gift. What did I think of it? I didn't know. Of course it was according to the Bible tho, the dancing and the speaking with tongues. I remembered reading of the speaking with tongues, but not of the dancing, so the boy got the testament and cited me to Matt. 11:17 and say [sic]: "We piped unto you and ye did not dance; we wailed and ye did not mourn." I read the 16 verse also and explained how we understand the parable. Then to Luke 15:25 how the Elder Brother of the Prodigal heard "music and dancing". I explained that we think that is the natural dancing of joy. "Do you think that was a sinful dance?" I didn't, for the Hebrews didn't usually have sinful dances. About the speaking with tongues I didn't know. Mrs. G said well, you know there are nine gifts of the Spirit, and this in one, tho it is not as important as to ___ (page torn) words understood. When I got home, Miss Rankin and I looked in ___ (page torn) r. $12^{10}$. Sure, there are nine gifts mentioned. It was interesting. ${ }^{11}$

\footnotetext{
${ }^{10}$ I Corinthians 12: 7-11 (King James Version). "But the manifestation of the Spirit is given to every man to profit withal. For to one is given by the Spirit the word of wisdom; to another the word of knowledge by the same Spirit; to another faith by the same Spirit; to another the gifts of healing by the same Spirit; to another the working of miracles; to another prophecy; to another discerning of spirits; to another divers kinds of tongues; to another the interpretation of tongues: but all these worketh that one and the selfsame Spirit, dividing to every man severally as he will."

${ }^{11}$ Letter to Addie Arthur, from her sister. 3 July 1916.
} 
From this letter it is clear that the Vardy workers knew about the neighboring churches and their practices. What they realized about them may well have been another matter.

As explained in the previous chapter, according to scholar Deborah McCauley, the mountain churches' traditions were far from the theology and worship styles of the Presbyterian home missionaries - even those as enlightened as Mary Rankin and Chester Leonard. The Presbyterians were not emotional in their worship; they based their faith on quiet reading of scripture and rational assent to its teachings. Their polity was representative, democratic, and their denomination was governed by written confessions. On the other hand, the mountain faithful built their fellowships on the witness of the Holy Spirit to individuals and on congregational autonomy. Presbyterians thought that clergy should be seminary-educated, while the mountaineers waited for God's call that was then ratified by the approbation of a particular body of believers. Many mountain preachers could not read or write but knew the Bible and the hymns they sang by hearing only. Writes McCauley,

The experiential traditions of the strong Calvinist heritage of grace influencing the worship life of almost all mountain church traditions - and an understanding of conversion as a gracious gift of God rather than a human achievement—-strongly conflicted with the nonemotive, rationalistic, merit-based, and accomplishmentoriented Victorian Christianities of the home missionaries. ${ }^{12}$

Another difference was the two groups' views of the relationship between faith and behavior. The missionaries believed that Christianity should result in upright living—no

\footnotetext{
${ }^{12}$ Deborah Vansau McCauley, Appalachian Mountain Religion: A History, Urbana: University of Illinois Press, 1995, 409.
} 
alcohol, no adultery, no fighting. They found mountain ways shocking and deplored the codes of mountain life they encountered.

However, the last difference is perhaps most telling. A northern Presbyterian missionary, Florence Stephenson, achieved renown for her work at the Asheville schools. In 1890, she gave a speech on "mountain whites" at the Women's Executive Committee of the Board of Home Missions. She deprecated the mountain religious traditions by saying, "So many of the girls who come to us unable to read a word are Church members. We must work wisely so as to not arouse their prejudices, and yet lead them to understand that they have not been made new creatures in Christ Jesus.. ${ }^{, 13}$ Stephenson was equating illiteracy with religious destitution. ${ }^{14}$ Statements like this encouraged the missionaries to believe that their way of doing Christianity—reading the Bible first and then making a declaration of faith — was the only valid way to experience the Gospel. This belief undergirded the establishing of schools as a first priority in the mountains. Of course, schools were needed, but literacy is not a prerequisite for salvation. Leonard, Rankin, and Wilson surely knew of Stephenson. Did they share her theological arrogance?

Leonard's long ministry in Vardy reveals him to have been true to his Presbyterian training. Rational, bookish, and deliberate in executing his plans for the community and exegetical in his preaching, his most obvious concession to the mountain religious customs was to allow baptism by immersion when someone requested it. Because he wondered why so few of the snake handlers in the community got bitten by the rattlesnakes and copperheads they brought into their worship services, he contacted

\footnotetext{
${ }^{13}$ Deborah McCauley, Appalachian Mountain Religion, 410.

${ }^{14}$ Deborah McCauley, Appalachian Mountain Religion, 410.
} 
herpetologists at the Brookline Zoo in Boston and learned that "snakes, when held in the air, tend to be disoriented and seldom bite and, when placed in an enclosure and provoked, lose some of their venom.." ${ }^{, 15}$ This was a scientific answer to what the people at Vardy saw as a faith question. For them, a person's unwavering belief determined whether or not the snakes bit.

\section{THE RACE QUESTION}

Yet, there is another question that wants settling: Did mission workers before him or Leonard himself ever acknowledge the race issue? There is nothing in writing to indicate that anyone used the word "Melungeon" after Christopher Humble's visit in 1898.

However, it seems likely that compromised status of the people and the racial stigma they bore could have been part of the attraction to the situation in Vardy. The social gospel popularized by Walter Rauschenbusch was based on ideas of social justice synthesized from reading the Old Testament prophets and certain selections from the Gospels. Rauschenbusch was a moderate Marxist who relied on Protestantism, the uniqueness of America, and the advance of knowledge to transform the inequities of the industrialized Northeast. ${ }^{16}$ Rauschenbusch emphasized a restructured present as the appropriate way for Christians to usher in the Kingdom of God, which he saw as a human affair, much like Jesus' ministry to the poor and oppressed of his time, resting on right human relationships. This theology was idealistic and revolutionary. Wrote Rauschenbusch, "There was a revolutionary consciousness in Jesus; not, of course, in the common use of

\footnotetext{
${ }^{15}$ DruAnna Overbay, Windows on the Past, 42.

${ }^{16}$ Robert Cross, "Introduction to the Torchbook Edition," in Walter Rauschenbusch, Christianity and the Social Crisis, 1907, New York: Harper \& Row, 1964, xv.
} 
the word 'revolutionary,' which connects it with violence and bloodshed. But Jesus knew that he had come to kindle a fire on earth." ${ }^{17}$ Quotations from Rauschenbusch resonate with Leonard's thinking and might have been things he wrote on $3 \times 5$ cards or slips of paper to post in his study for the purpose of staying focused on the tasks before him. "The highest type of goodness is that which puts freely at the service of the community all that a man is and can." ${ }^{, 18}$ And, another: "In the new social order, . . . each must seek to give the maximum of service, and he would be the greatest who would serve utterly." ${ }^{, 19}$ These quotations sound very much like things Leonard wrote about his work at Vardy in both Presbyterian and secular publications; he was adapting the urban social gospel doctrines to his mountain environment.

Jim Crow wore a different hat in East Tennessee and Southwest Virginia. There were (and still are) few African-Americans. Therefore, doctrines of white-supremacist domination applied to Melungeons, the darkest members of the predominantly white society. Jesse Stuart's Daughter of the Legend depicts the discrimination the Melungeons faced in Hancock County in the early twentieth century: inability of a white boy to get a marriage license permitting him to wed a Melungeon girl, refusal of a local physician to provide medical care, unfair treatment by the sheriff, no access to restaurants in town (Sneedville), and disdain from merchants. ${ }^{20}$ The consciousness of race that Stuart portrays shows the reality that Hancock County residents, white or Melungeon, lived with

\footnotetext{
${ }^{17}$ Walter Rauschenbusch, Christianity and the Social Crisis, 1907, New York: Harper \& Row, 1964, 85.

${ }^{18}$ Walter Rauschenbusch, Christianity and the Social Crisis, 67.

${ }^{19}$ Walter Rauschenbusch, Christianity and the Social Crisis, 86.

${ }^{20}$ Jesse Stuart was the college roommate of Drew Williams, who figures prominently in the history of the Vardy Community School and who married Alyce Horton, the grand-daughter of Batey and Cynthia Collins. Stuart had dated a Melungeon girlfriend of Alyce's when they were all students together at Lincoln Memorial University in Harrogate, Tennessee. He wrote Daughter of the Legend in the 1940s but didn't publish it until 1965.
} 
every day. For Leonard and Rankin this background was something they must have faced. They were in the midst of a community comprised of the poor and the oppressed. Not only did the people in Vardy exemplify the problems that Samuel Wilson had identified in his book that were common to many in the mountains, they had the added burden of difference marked by skin color. Leonard's awareness of race, even though he never to my knowledge wrote the word "Melungeon" on any public document, is evident in the notations about skin color that he made on the cards of his initial census/survey.

Contemporary theorist and writer bell hooks has much to say about racial discrimination in America. Even though she writes from inside the African-American experience in the late twentieth century, her thinking can be applied to any racially marginalized group in any time period. For hooks the first step to moving beyond stereotypical thinking is recognition of difference. She says, "The fantasy of whitesupremacist exclusion is not pitted against the reality of diversity. People of color who choose to self-segregate as a means of protecting themselves from racial assault cannot avoid facing that diversity.... [T]he teachers who taught me in all black settings to recognize the limitations of skin color, to seek community with like-minded schools, help me to understand the value of moving beyond race while always respecting that race matters" [italics mine]. ${ }^{21}$ hooks contends that getting beyond the race issue is not possible unless race is acknowledged. She affirms that school experiences in particular are important to helping children of color both understand race and overcome it. Leonard said repeatedly that he was equipping his students to be the best they could be either in the confines of the Vardy community or in the culture outside. It seems that, at least in

\footnotetext{
${ }^{21}$ Gloria Watkins (bell hooks), Teaching Community: A Pedagogy of Hope, New York: Routledge, 2003,
} 80-81. 
his own mind, he would have had to come to terms with what "Melungeon" meant in the valley, the county, and the region. Leonard was a contemporary of the infamous Walter Plecker; he must have been aware of Plecker's efforts to brand Melungeons as racially excludable in Pennington Gap, Virginia, just a few miles from Vardy. Even though he never uses the word "Melungeon" in his public writings or in the church records, it would be next to impossible to live in Vardy and not know. No one would deny that educationally Leonard was very successful. Some of his students who stayed in Hancock County became civic leaders. Many who left for other places lived comfortable and satisfying lives. I believe that he must have figured out how to confront the race issue; if he hadn't, there wouldn't be so many success stories. By giving his students academic competence and confidence, coupled with tools to deal with their racial stigma, he enabled them to fight for their rightful place in American life.

But despite outward markers of success, a deep consciousness of difference remains for many with Melungeon heritage. An anecdote narrated by DruAnna Williams Overbay poignantly shows how real "Melungeon" was and what it meant during Leonard's tenure. Overbay's mother, Alyce Horton Williams, was a descendant of both original settler Vardy Collins and his grandson so prominent in the Vardy story, Batey. In October of 1947, I became aware that I, too, am a Melungeon. Because I went to the Vardy Community Elementary School, where both my parents were teaching, I was permitted to go down the hill to retrieve the mail from our home mailbox during recess. Usually my sisters Margaret and Charlotte went after the mail, but they were busy planning an assembly program and the task fell to me. I always looked forward to being the first in the family to look at the magazines. 
On that particular day the Saturday Evening Post arrived. The article "Sons of the Legend" caught my eye because of my recognizing pictures of our neighbors Asa Gibson, Laura Mullins, and others. ${ }^{22}$ Sitting on the school steps, I began thumbing through the magazine, becoming more and more excited. When I yelled to other students to come and look at the magazine, my mother rushed out of the classroom and snatched the magazine from my hands.

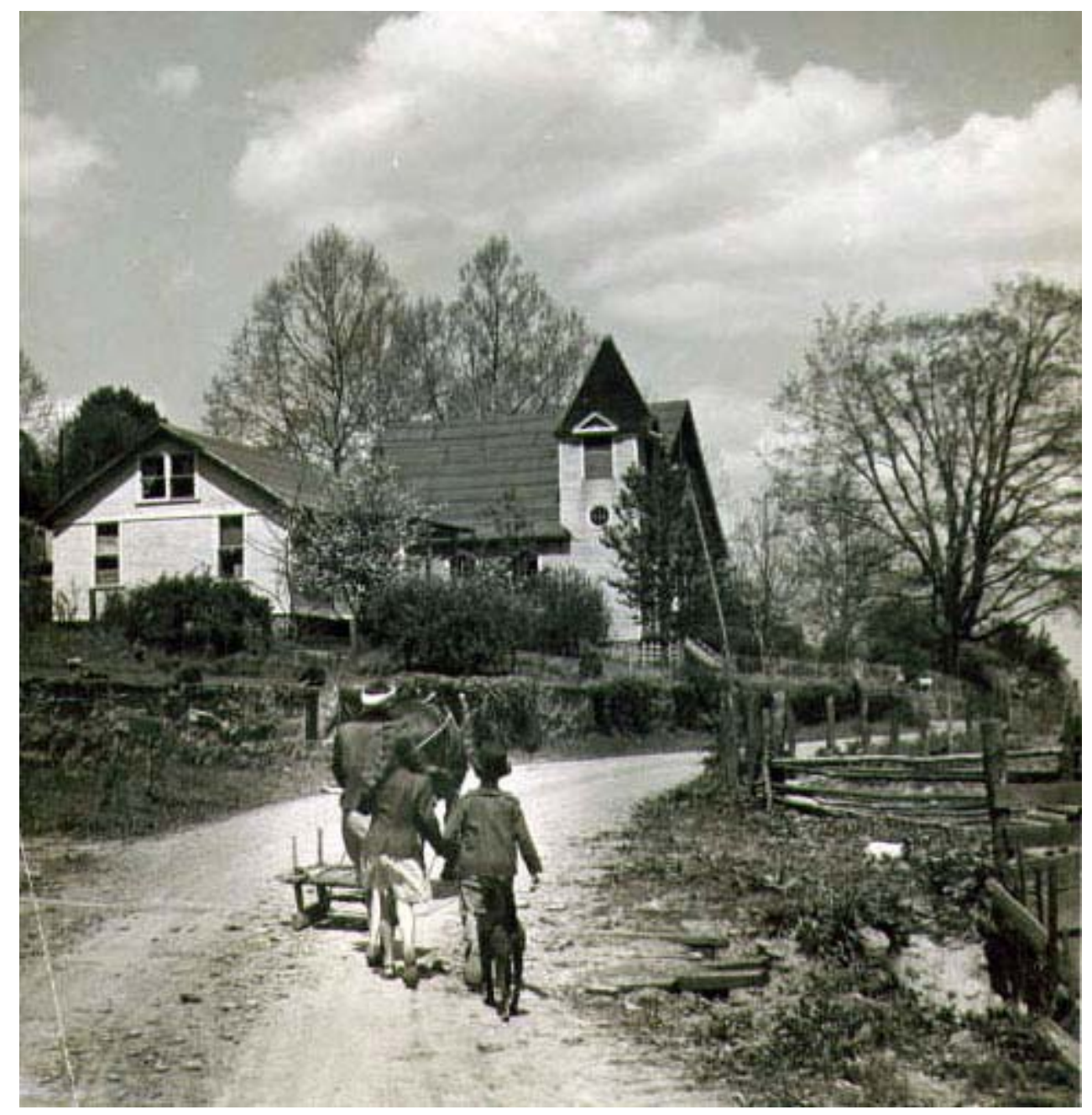

This image was the lead photograph in the Saturday Evening Post Article. It shows Laura Mullins and her children with their mule on the Vardy road. Of course DruAnna Williams (Overbay) would have recognized her schoolmates. The photographer had been standing right in front of the Drew and Alyce Williams home when he took this picture. The school is out of the camera's range at left, up the hill behind the church.

\footnotetext{
${ }^{22}$ William Worden, "Sons of the Legend," Saturday Evening Post 18 October 1947: 28+.
} 
That night my mother's angry words to my dad and my maternal grandfather awakened me. She was very upset and began screaming, "Why can't they leave us alone? I wish I never had to hear that word [Melungeon] again!" Of course, the $u s$ did not include my dad and her dad, for only my mother denied the Melungeon heritage that our genealogy studies have proven. Despite the fact that I was only five, from that day on I have known that I, too, am a Melungeon. That undercurrent of being a Melungeon was there-unspoken and yet known. ${ }^{23}$

This drama played out on the steps of the Vardy School and in the Williams home that was adjacent to the campus of the Presbyterian Center. It is inconceivable to me that Chester Leonard, or Mary Rankin, could have denied that race was an issue or that it truly did matter for the people to whom they dedicated their lives. They must have known.

\section{BUILDING COMMUNITY}

Rauschenbusch was as certain in the first decade of the 20th century as hooks is in the first decade of the $21^{\text {st }}$ that there is a magic about community that is central to effective education. Rauschenbusch points back to first century Christian churches citing both their humanitarian emphases and theological bases. "They were not communities for the performance of a common worship, so much as communities with a common life. They were social communities with a religious basis"(italics mine). ${ }^{24}$ Leonard's vision for

\footnotetext{
${ }^{23}$ DruAnna Williams Overbay, Windows on the Past. $2^{\text {nd }}$ ed. Macon, GA: Mercer University Press, forthcoming, 11-12.

${ }^{24}$ Walter Rauschenbusch, Christianity and the Social Crisis, 119.
} 
Vardy couldn't be summarized any more succinctly—he wanted to build a social community with a religious basis.

I have found no diaries and few letters to chronicle the Leonards' early years in Vardy. The church records and two published articles tell the story in print. For Leonard it was certainly a time of assessment and exciting opportunities. For Josephine, who had grown up in Birmingham, Alabama, a large city, it must have been a struggle to adjust to the isolation that Vardy imposed. And for her it might have been a time of disappointment as it became clear to her that she and Chester would not have children of their own.

Yet, the lack of written documentation makes the record of what Leonard did even more remarkable. Rauschenbusch had said that the first duty of the early church was "organized helpfulness." Leonard took this to heart. He cautiously set about finding the perfect paradigm and then putting his ideas into practice. In Teaching Community bell hooks talks about the habits of the heart and the values that those who are builders of community share; they are "generosity and fidelity and mercy, a sympathetic imagination, a deep and abiding concern for others, a delight in nature and human company and all forms of beauty, a passion for justice, an sense of restraint and a sense of humor, a relish for skillful work, a willingness to negotiate differences, a readiness for cooperation and affection." ${ }^{, 25}$ The record of what Leonard did and the stories people who lived in Vardy or who attended the Vardy Community School still are telling bear witness to his skill as an intentional builder of community.

\footnotetext{
${ }^{25}$ Gloria Watkins, Teaching Community, 197.
} 
He began his work in Vardy by doing an extensive survey, to determine the "community background" as Leonard called it. "This included the history and traditions of the people; the resources of the section; a census to get the population, the education, health, habits, and religious beliefs of the inhabitants. We allowed six months for the taking of the survey and tabulation. ${ }^{26}$ Leonard notes in his Presbyterian Advance piece that the survey was "dangerous" because it is difficult, even in the face of data, to abandon preconceived ideas about what the survey might mean and how to proceed with one's work as a consequence. This admission is part of Leonard's wisdom and one reason why he was so successful in his work at Vardy. When Leonard went to Vardy in 1920, some mission fields were already being abandoned. Others were imposing European folk traditions like Danish dancing or elaborate sword routines performed by select teams of students. Some Appalachian workers were busy encouraging parts of Appalachian culture they found "meaningful," like the collection

\section{Do's \& Don't's}

1. Do not expect too little or too much. 2. Do not be disappointed if you do less, or get less, than you expected.

3. Do not be over-elated if your expectations are surpassed by your accomplishments. 4. Do not begin with too great a proposition for the people or yourself. Build up self-help habits by getting little things done. 5. Do not plan for today only. Look ahead for at least ten years: better, twenty.

6. Set a definite and worthy goal. 7. Educate people to wish to help. All people need to "be sold. "Do not expect them to jump at every proposition that you offer. 8. Plan your work; be willing to change your slans; then go to work.

\footnotetext{
${ }^{26}$ Chester Leonard, "Helping a Community," 10.
}

As regards the survey, there are $3 \times 5$ cards in the archive of the Vardy Community Historical Society that are a detailed census of each family, in addition to noting names, ages, and health conditions, the cards tell whether the family members belonged to and/or attended the Presbyterian Church, if the adults in the family could read, whether there were any books in the home, and the physical characteristics of each person such as skin shade, hair and eye color, etc. 
and preservation of old English ballads, while disdaining other equally prominent mountain cultural traditions such as banjo music or square dancing. Leonard had obviously been doing a lot of thinking after his summers with Miss Rankin about what Vardy had and what Vardy needed. He did not impose folk traditions from outside the region as a part of his program.

Leonard must have carried the list of "Do's" and "Don't's" in his pocket. ${ }^{27}$ Then he took an entire year after the completion of the survey to check up on the accuracy of his findings and to try to win the confidence of the people. Says Leonard, "We did little and listened much." 28

The "scientific" way that Leonard went about gathering data and making plans for a comprehensive school and community program shows clearly the influence of another thinker who was his contemporary, John Dewey. Dewey in his Democracy and Education had connected the principles of representative democracy, effective education, and the scientific method. Dewey emphasizes the necessity of scrutinizing existing conditions to clarify a problem that wants solving and then proposing a hypothetical solution and acting to effect change. ${ }^{29}$ This is the first evidence of Dewey's profound influence on Leonard but not the last.

Leonard relates that health work and recreation were the first openings he had to begin implementing his new programs. Some health problems among the children mandated a place for supervised play. Leonard offered to pay for playground equipment if the men would make a level space. This spurred the men of the community to action;

\footnotetext{
${ }^{27}$ Chester Leonard, "Helping a Community," 10.

${ }^{28}$ Chester Leonard, "Helping a Community," 10.

${ }^{29}$ John Dewey, Democracy and Education, 1916, New York: The Free Press (A Division of Simon and Schuster), 1944, 150-51.
} 
bottom land was too valuable for crop space, so the playground had to be built on the hillside. In order to accomplish that, dirt had to be moved by hand or by mule power. By the end of the summer, Saturday workings had transformed a ravine into a flat area. The women brought dinner every week. Swings and the famous trolley were installed. A ball field and a place for horseshoe competitions completed the playground.
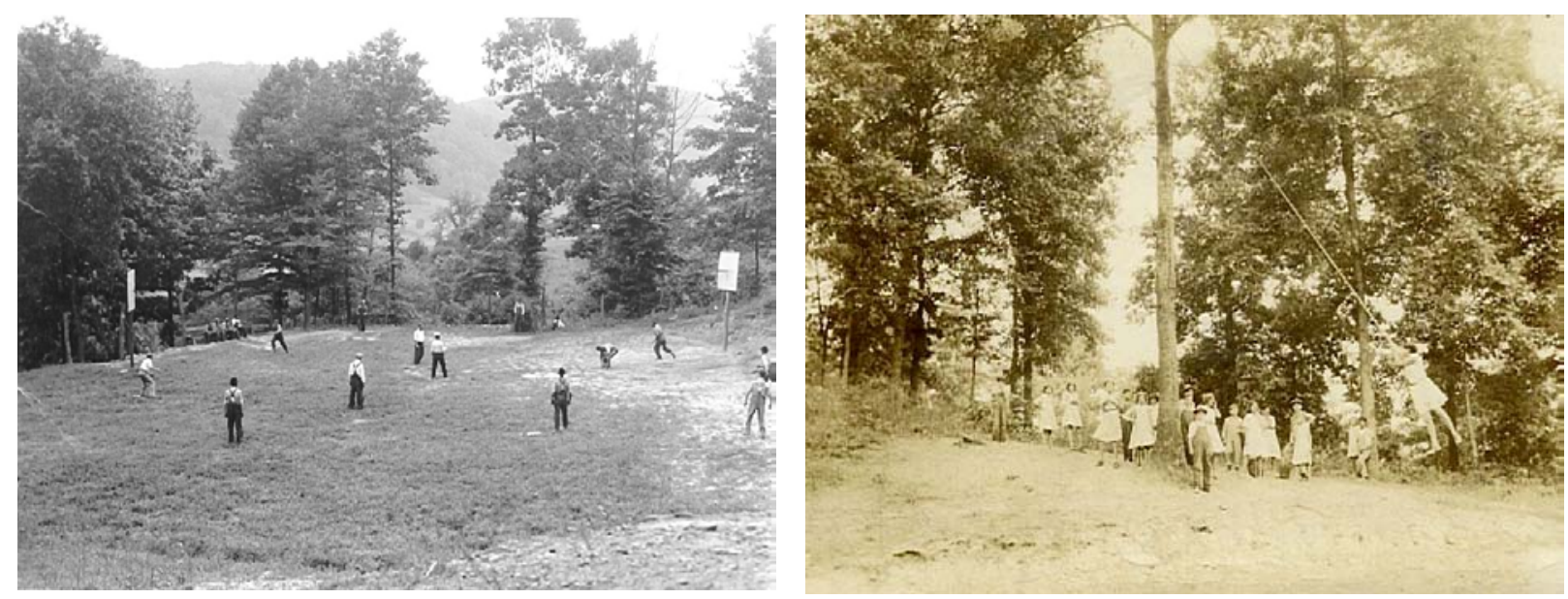

The ball field and one of the rope swings are immortalized in these pictures from the collection of Willa Mae Gibson Mullins Moore. Mrs. Moore, known to everyone as Blue Eyes, was a cook at the Vardy Community School in the 1970s.

Appalachian workers took "play" quite seriously. They believed that if residents of the hills and hollers could learn to play together in creative ways, they could transfer the wholesome relationships into other settings and begin to collaborate on community development projects. As the Leonards attended yearly meetings of Presbyterian workers from the mountain "uplift" projects and possibly the broader meetings of representatives from all the settlement schools, he was certainly familiar with the emphasis on play at the various schools. However, I do not believe that he valued recreation above other aspects the total program as Katie Doman alleges in her unpublished paper. ${ }^{30}$ Doman suggests that recreation was a recruiting tool and central to his pedagogy. She bases her paper on

\footnotetext{
${ }^{30}$ Katie Doman, "Recreation as Recruitment and Pedagogy," 9.
} 
Leonard's statement that "our purpose has been to help children develop rightly in body, mind, and spirit" 31 and further alleges that it is no accident that the word "body" is first on the list. My take on this statement is different: the "body, mind, and spirit" phrase is biblical in origin and states a foundational principle of the Presbyterian Church's mission endeavors. Presbyterians said then, and still do say, that a missionary cannot talk about spiritual matters or teach academic subjects to someone who is sick or hungry; a person must be healthy before he/she can attend to instruction in a classroom or hear the rudiments of the Gospel. Leonard's first playground filled a need he identified, but it was not the centerpiece of his dream for the work in Vardy.

Leonard translated Rauschenbusch's term "Kingdom of God on earth" to St. John's phrase “Abundant Life," a concept that for him left no part of a person's experience outside its circumference. He wanted nothing short of the best he could imagine for the Vardy Community. Once the school was completed he expanded the single playground into a three-level graded play area. The younger children stayed closest to the school building, and the older children could play further up the hillside. "The playground equipment has a definite purpose," he wrote. "Two trolleys of different length and speed provide strengthening of the limbs, increase of chest expansion, and not too strenuous interesting exercise. ${ }^{, 32}$ Every person I interviewed remembers the trolleys with great affection saying they would wait in line the entire recess period just to get one ride on a trolley. His Mountain Life and Work article continues, "Single rope swings develop grace and coordinated muscle control. The ball ground teaches fair play, honesty, and skill. Rope jumping improves 'timing' ability and coordination. Pitching horse shoes

\footnotetext{
${ }^{31}$ Chester F. Leonard, "Vardy Community School," Mountain Life and Work" January 1938, 4.

${ }^{32}$ Chester Leonard, "Vardy Community School," 5.
} 
adds to skill in handling muscles. See-saws develop the sense of balance in the younger children." ${ }^{, 33}$ These descriptions echo Maria Montessori in her 1912 book The Montessori Method that articulated a pedagogy centered on the holistic development of children. ${ }^{34}$ Yet, here was something bigger and more life changing than wholesome play in his mind. Leonard, during his first five years on the field, dreamed about what a mountain school in the midst of a vibrant and wholesome community would be. His ideas were practical and based on the needs he saw around him as well as what his survey showed. His 1928 article in the Presbyterian Advance was written while the big new Vardy Community School was under construction. The cornerstone had been laid in 1926, and classes moved into the new building during the 1929-1930 school year. The building process and product reveal many things about Leonard and his vision for Vardy. As he had with the first playground, he involved the entire community in the project. He wanted the people to "own" the school and not expect handouts forever. Here is the story in his own words,

Friends offered us $\$ 3,500.00$. At a meeting of the parents we put the proposition before them and offered to build providing they would give enough lumber. Eleven thousand feet were offered and rejected [italics mine]. The meeting adjourned and the men got together. The next day two of the men came and begged for two weeks to see what could be done. As a result the community gave 60,000 feet of pine and oak lumber, besides some labor. ... Our school is being built without a carpenter on the "job." The "preacher" turned architect; his father became boss carpenter; the men of the community took up hammer and

\footnotetext{
${ }^{33}$ Chester Leonard, "Vardy Community School," 5.

${ }^{34}$ Maria Montessori, The Montessori Method, 1912, New York: Schocken Books, 1964.
} 
saw; the boys of the manual training classes started to "tote" lumber and square it up; the women began to brag about the work; and people visiting us tell us that our school building will be the best in the county. Incidentally, our men are learning a trade; our boys are getting practical work; and the entire community is having the joy of helping itself. ${ }^{35}$

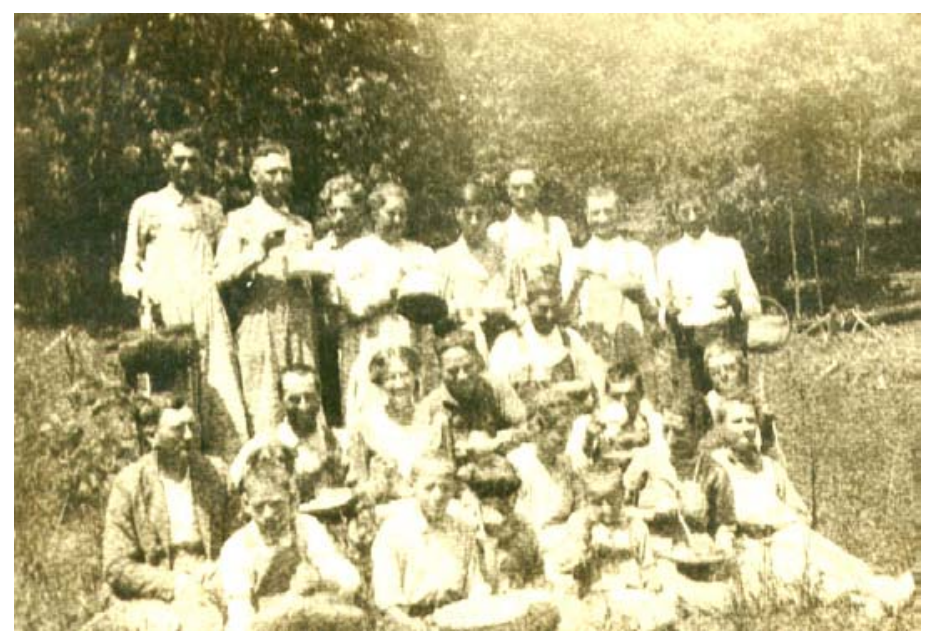

Vardy residents posed for a picture at one of the workings held to build the school.

The school building project was neither the first nor the last time that Leonard "cancelled" plans because of lack of community support. He felt that the help being provided by, in this case, the Englewood, New Jersey, Church or in other cases the Board of National Missions should not be taken for granted. The way he grew people into the tasks was also a hallmark of his method of community participation. Jim Callahan reports in Lest We Forget what he learned from his mother Ollie Bales,

Every able and cooperative citizen was recruited for lumber donations and processing. Logan and Nancy Miser, Dan Horton, Herbie Collins, Bob Bales, Connor Bales and others donated lumber. Everybody worked, including a few

\footnotetext{
${ }^{35}$ Chester Leonard, "Helping a Community," 10 \& 17.
} 
females. Ollie Bales, a young, tomboyish teenager, dragged the cut logs from the woods to the sawyers with a team of mules. She recalls the period with, "I drug them logs outa the wood, and there weran't no women round." ${ }^{36}$

Leonard was once again demonstrating success at winning the hearts, minds, and hands of Vardy citizens. His scientific method of ascertaining the status quo and the hypotheses that method generated seemed to be yielding positive outcomes.

The school was remarkable in many respects. The campus of seven acres boasted the school, the church, the manse, the mission house, a stable/garage, a woodshed/blacksmith shop, the summer house (where Leonard's parents moved in the hot summer months), a dairy, chicken house, well house, fountain house, and three playgrounds. Sheep kept the grounds "mowed." The Presbyterian community center combined the best of the settlement school tradition with then current pedagogical methods and Leonard's own very definite ideas about education. The school building was three stories with 96 windows. The bottom floor housed the manual training area, the primary school classroom, and the library. The second floor had three regular classrooms and an auditorium. The top floor had the kitchen and lunchroom, where cooking and sewing classes met, an apartment for Leonard's parents who came to teach the manual training and home economics classes, and quarters for the visiting teachers. These visitors, retired pastors and educators from many colleges, universities, and seminaries, were an important part of Leonard's curriculum plan in the early years. Chester Leonard's articulated goal was "a community with a desire, the will, and the ability, to live the 'Abundant Life.' Our general plan was to build up the economic, social,

\footnotetext{
${ }^{36}$ Jim Callahan, Lest We Forget, 222.
} 
recreational, physical, mental, and spiritual life of the entire section. ${ }^{, 37}$ The existing church was a key element, but the school was undeniably the centerpiece of the Vardy mission.

It is apparent that Leonard had to battle the county educational bureaucracy to realize his dreams. He wrote in a published article,

One day the "preacher" announced that school would open in the church on Monday and that all who came had to bring something for tuition; everything useful would be acceptable. One man who offered a 'possum was told to send his children. Not a child reported to the county school. All came to us. As a result, after a little worry and work, the county gave us the salary for the teacher. This amounted to $\$ 200$ a term and was used to provide books for the children, maps, tables, and desks. ... Our enrollment doubled and finally tripled until we are using the school building [the 1902 Presbyterian-built school], two rooms in the church, one room in the mission home for homemaking classes, and a temporary building for manual training. We have two half-time teachers and one who teaches all day. We also have a manual training teacher and one for homemaking [Leonard's parents]. Our attendance averaged 97 percent of the enrollment during the last term. ${ }^{38}$

An interesting perspective on the Vardy school and what it meant is articulated by students who made the transition from the makeshift quarters in the 1902 school building, the church, and the mission house to the elaborate new building on the side of Powell Mountain. Oakey Collins explained in his oral history interview, "My first year at Vardy

\footnotetext{
${ }^{37}$ Chester Leonard, "Helping a Community," 10.

${ }^{38}$ Chester Leonard, "Helping a Community," 9.
} 
was the school year of the fall of 1928. That was the beginning of the new Vardy School; however, the new building had not been completed. The church was converted to serve as a schoolroom as well as to have church services. Grades fourth through the eighth attended school in the church." ${ }^{39}$

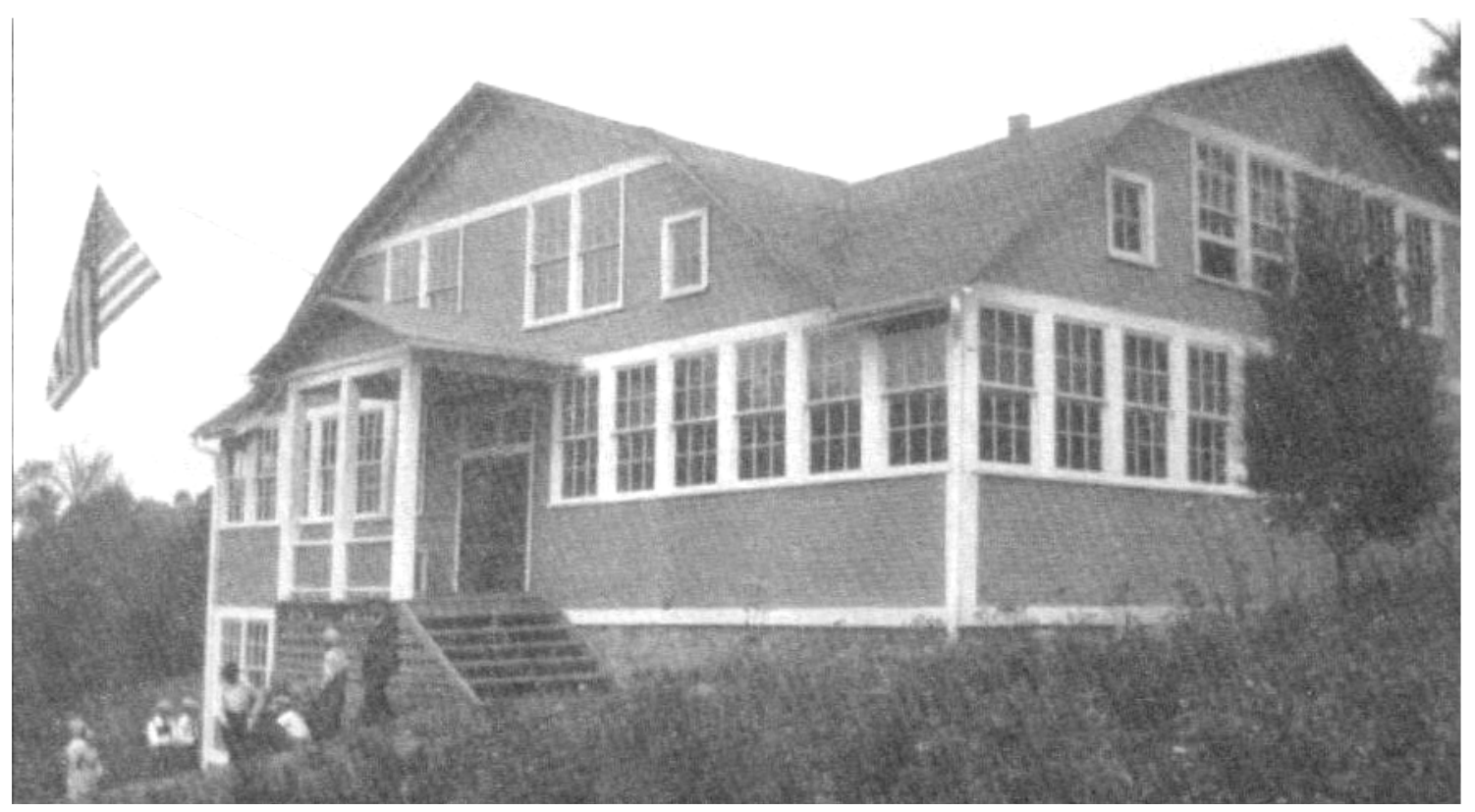

Three stories, 96 windows, and powered by electricity from a generator, the Vardy School was unlike any country school before or since. The Melungeon children had advantages over the town kids in Sneedville.

The new school building boasted electric lights powered by a gas generator; it wasn't until years later that the valley residents had electricity. Pride in the well-designed and lavishly equipped school is evident in former pupils' reminiscences, "Vardy was the most beautiful school in the whole county. ... On the first day that I went, I could see it was so big that I thought I'd never be able to get through that school. . . . It was a very big school. It was one of the finest schools in the county at that time."40

\footnotetext{
${ }^{39}$ Oakey Hendrix Collins, "Vardy Oral History Interview," interviewed by DruAnna Overbay, Morristown TN, 25 August 1999.

${ }^{40}$ Lloyd Williams, "Vardy Oral History Interview," interviewed by Katie Doman, 5 March 2000.
} 


\section{CURRICULUM AT THE VARDY COMMUNITY SCHOOL}

Philosopher John Dewey posited that formal schooling, or education, becomes a necessity "when social traditions are so complex that a considerable part of the social store is committed to writing and transmitted through written symbols. ${ }^{, 41}$ Life in Vardy, as it was being lived when Chester Leonard arrived, had not yet crossed that divide. However, the larger communities of Hancock County, the state of Tennessee, the region of Appalachia, and the nation had already entered into that reality. Batey Collins knew the need for literacy was imminent. Mary Rankin knew that the world outside the valley was already dependent on reading and writing. And, Chester Leonard knew his mandate was to move Vardy's children into a reality that included literacy as a basic assumption. Even though many Vardy citizens could neither read nor write even as late as 1920, the necessity of learning how and of beginning to conduct their lives in the artificial symbolic code of written language was bearing down upon them; the isolation fostered by both geography and entrenched prejudice could not continue. Said Dewey, "[A]s soon as a community depends to any considerable extent upon what lies beyond its own territory and its own immediate generation, it must rely upon the set agency of schools to insure adequate transmission of all its resources. ${ }^{, 42}$ By the 1930s Vardy farmers were beginning to compete in regional markets and to sell their timber to outsiders. Vardy children were already starting to leave the valley for work in cities of the mid-Atlantic and upper Midwest. Literacy was necessary for both those who left as well as for those who owned enough land to stay.

\footnotetext{
${ }^{41}$ John Dewey, Democracy and Education, 1916, New York: The Free Press (Division of Simon and Schuster), 1944, 19.

42 John Dewey, Democracy and Education, 19.
} 
Leonard's curriculum was rooted in what he saw as the needs for his students and their families. I think he had a sense that he was an agent of radical social change. $\mathrm{He}$ acknowledged that many members of the community could not or did not care to read when he began his work in the valley. Unlike some of the settlement school administrators, who relied on the folk school model, Leonard was unfailingly practical. He noted in 1938,

Many of our people do not go away to high school. Therefore our purpose is to teach as much as possible in our own elementary work. Pupils who have the ability and the desire to go away to other schools are given the opportunity. But we are here to do all we can for those who will go no higher. So we balance our work as much as possible to be a foundation for life after school days are over. ${ }^{43}$ This statement is congruent with his stated purpose in the 1928 Presbyterian Advance article and his realistic assessment of the future prospects of the Vardy students. "We do not beg them to stay, and we do not force them to leave. If they remain among us, we shall have provided leaders that will take the next generation another step or two up the ladder of progress. ${ }^{, 44}$

Participants in the Vardy Community Historical Society Oral History Project remember that students' work in the early years was individualized. Each student had a clipboard that hung on the classroom wall. Every day there would be a regimen laid out on the clipboard. Students proceeded at their own pace. Wrote Leonard,

the teacher [who worked by subject rather than grade level] can follow the advancement of a pupil through the different grades, thus keeping him going as

\footnotetext{
${ }^{43}$ Chester Leonard, "Vardy Community School," 6.

${ }^{44}$ Chester Leonard, "Helping a Community," 17.
} 
rapidly as possible, and recognizing also when he has reached the limit of his abilities. Occasionally this results in giving the child a period of "rest" in a subject until he "grows' to the level of the next step. Or it may lead to the child carrying advanced work in one group of classes and retarded work in another. All children are not alike and we believe that they should be allowed to advance as they develop along their particular lines.... The child may go forward as rapidly or as slowly as may be necessary. He is not held back because others in the class are slower. And he is not dragged along so rapidly that he does not understand what he is doing. There is no shame in being slower than another. ... No child is required to go back and take a book over because he has failed in it. Each unit is mastered before it is laid aside. If the pupil does not understand at first, new material is offered in an entirely different way until there is no question about what it means. This eliminates monotony and builds up a background for the next step. $^{45}$

This can be viewed as the pedagogy of the one-room school expanded to whole school size. It shows Leonard and Rankin's fearlessness about innovation and their strong faith in the abilities of their students.

\footnotetext{
${ }^{45}$ Leonard, "Vardy Community School," 6.
} 


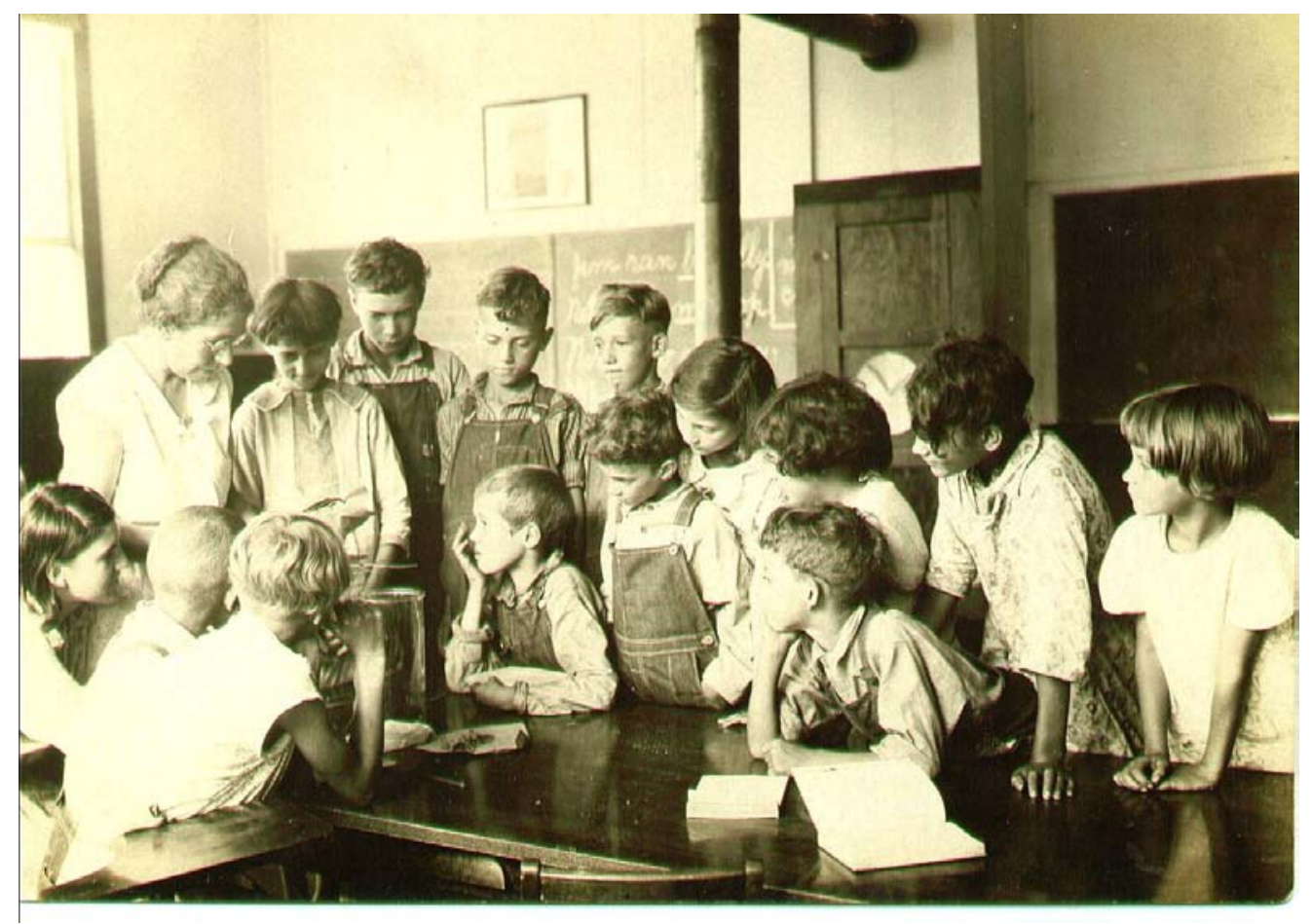

Students gather around Mary Rankin to examine a small animal in a cage. Leonard and Rankin believed in the importance of helping the children learn about the plants and animals in the valley.

what was going on at the Vardy Community School. They remember garnering all the top prizes in county academic competitions. They remember the projects they completed in the manual training classes. ${ }^{46}$ They remember the hot lunches in the upstairs dining room. They remember the love that was lavished on them by all the Leonards-Pastor Leonard,

\footnotetext{
${ }^{46}$ Oakey Collins proudly showed me an elaborate doll house he built before he left Vardy and formal schooling at the end of fifth grade. This man, with only a fifth grade education, guided the Historical Society Board through the intricacies of gaining tax-exempt status and putting the church and other campus buildings on the National Register of Historic Places. He was adept in the formal literacies of government bureaucracy.
} 
Chapter 4 "Chester Leonard: Beyond the Basics"

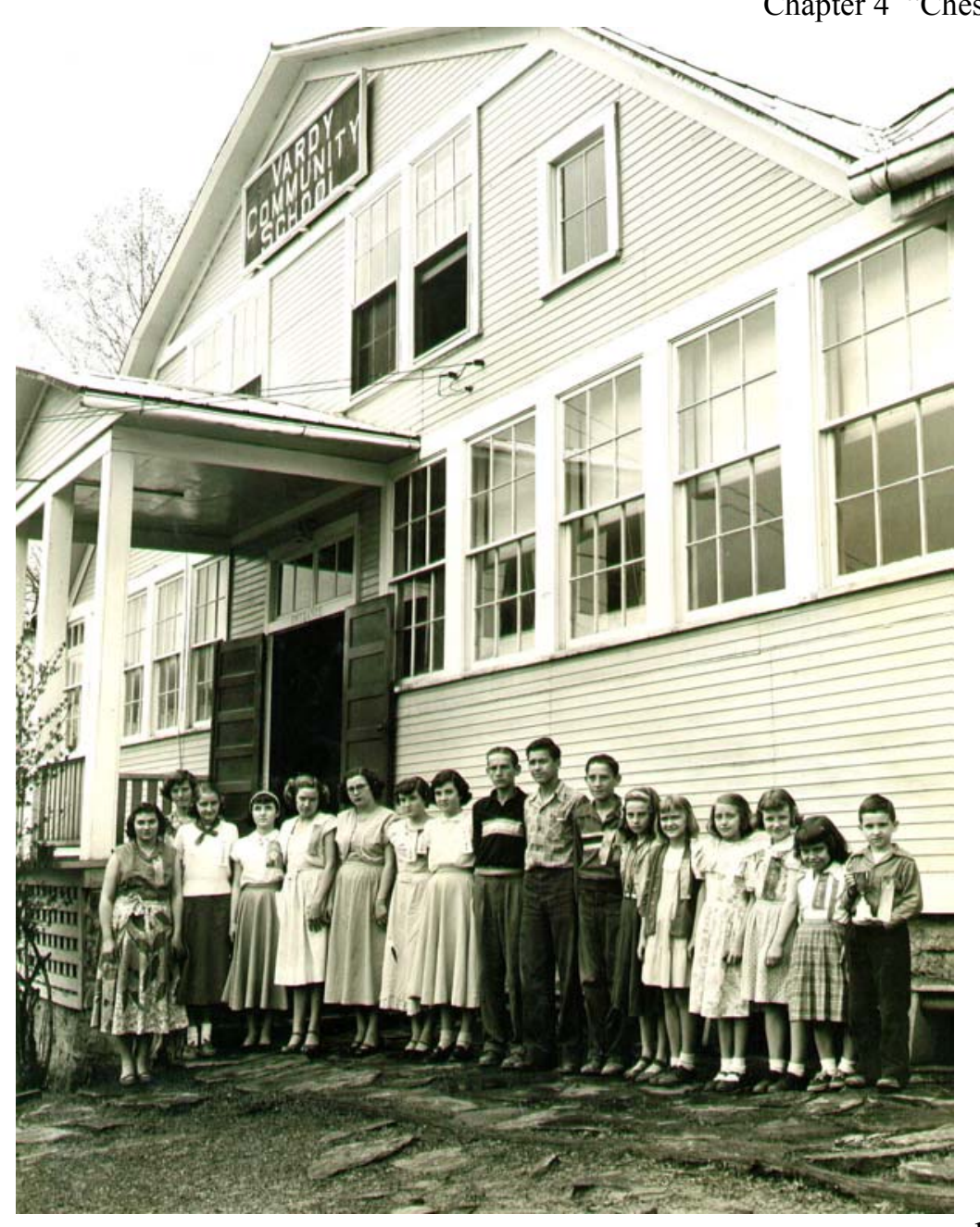

Mrs. Leonard (his wife) who

told stories every week to the

school children, Mother

Leonard (his mother) who

taught home economics, and

Father Leonard (his father)

who conducted all the manual

training classes — and by Miss

Rankin.

Leonard created a

remarkable school in the

middle of nowhere that

fostered both a love of

Students pose with their ribbons from a county competition about 1950.

learning and academic

DruAnna Williams (Overbay) is fifth from the right in this photo.

sophistication in its students.

County residents and bureaucrats were both envious and threatened. There were some

skirmishes over who would control the school; the county thought it had the right since it was paying one of the teachers. But Leonard would have his own way; he took his case to Nashville to preserve his right of autonomy. His 1934 annual report to the church congregation reads,

In May, having been nagged so long by different parties who were trying to tell us how this school had to be run and feeling that now was the time to settle things, I made a trip to Nashville, where I conferred with the Commissioner, his assistant, 
the directors of high schools and elementary schools, and there settled for our community the standing of this school. At Nashville the following statements were made:

1. The Vardy School shall be allowed to experiment in its own way with no state hindrances as to textbooks, equipment, or methods requirements. It shall be considered the laboratory school for that Eastern section of rural work in Tennessee and shall be unhampered.

2. The Vardy School, being so far in advance of the other county schools, should not submit its pupils to countywide examinations. The teaching at Vardy does not embrace textbooks only but supplementary materials. Therefore, to require county examinations would mean a return to itemized material found only in textbooks, some of which is many years out of date.

3. The State is very glad to consider Vardy as a County School and hopes to have its cooperation in the future as it has had in the past in preparing pupils for life.

That visit to Nashville made it possible to answer those trying to put pressure on us from outside and also some who were supposed to have the interest of our school at heart. ${ }^{47}$

In addition to the individualized curriculum plan, Leonard started a small community museum that began with fossils from the local area, Indian relics that the students found on their own farms, birds' nests and other nature items, as well as

${ }^{47}$ Chester F. Leonard, “Annual Report,” Vardy Community Presbyterian Church Records, 1934. 
implements and documents donated by older people in the valley. He taught geography using films and his extensive collection of National Geographic magazines.

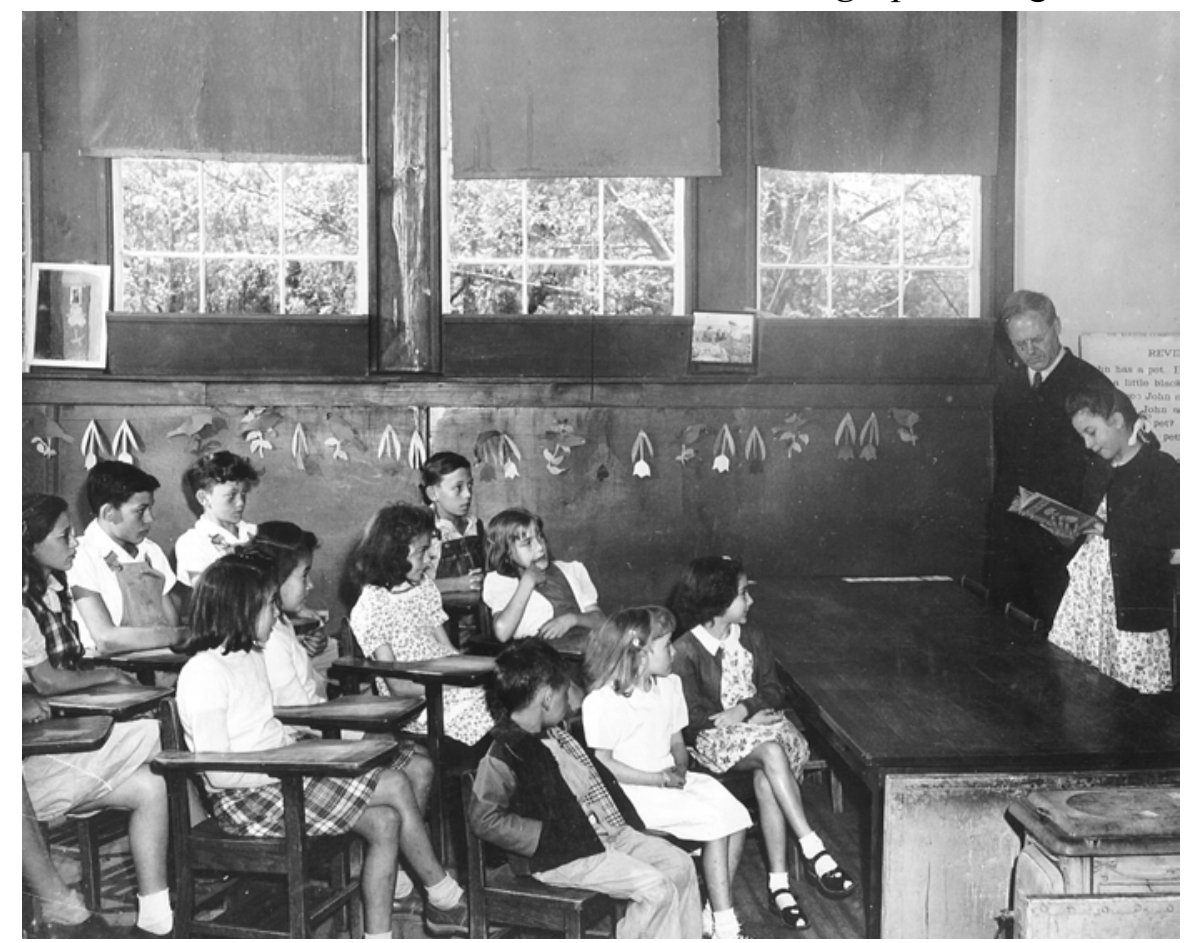

Chester Leonard is shown at right with a class of middle grade students.

Leonard had a large collection of "glass lantern" slides and an elaborate projector to show them with. The electricity at the school provided by "the Delco" ran the projector. In a 1939 article written for a church publication, he wrote, “[W]e have collected over 4,700 slides that illustrate almost any thought that we wish to make impressive. These slides are on various subjects, including Bible, history, geography, health, citizenship, and agriculture. ... [I]f the slides fit the thought, too few are seldom shown. ${ }^{, 48}$ The students interviewed in the oral history project remembered the slides as being very effective. "Slides provided us a window to the outside world," said one. ${ }^{49}$ Audio-visual presentations were an important part of the curriculum; in addition to the

\footnotetext{
${ }^{48}$ Chester F. Leonard, "How We Use Slides," Church Management, Dec. 1939.

${ }^{49}$ W.C. Collins, personal comments to DruAnna Overbay, 7 Aug. 1996.
} 
slides there were films, and the students heard national news on the radio every school day.

Much information to support written and oral classwork was displayed on charts that hung on the classroom walls. Leonard believed that the students who were interested would absorb this material naturally. "During class time and tests," he wrote, "we tell children to make use of anything that the teacher has allowed to remain in sight. We do not wish our children to feel that they are cheating if they glance from their papers while writing. ${ }^{, 50}$

Chester Leonard was passionate about making sure his students learned as much as they were capable of; his goal was, after all, the "Abundant Life." He insisted that as early as third grade the students begin to learn the critical thinking skills they would need to be competent adults. Nowhere was this more evident than in his social studies plans: Road maps, time-tables, bus schedules, boat-sailings, globes, maps, and the National Geographic magazines are more important and up-to-date than any textbook that we can find. Of course many supplementary books suited to the needs of the pupil are used. In the third and fourth grades we teach the pupils how to find what they need and how to use it. And much note-taking is practiced so that they will know what is of importance and what is not worth saving. At first this work is rather crude, but we have been surprised at the ability of some children in learning how to sift material. ${ }^{51}$

Leonard's distinctive curriculum plays out many of the tenets of Dewey's thought. Dewey talked about the usual school subjects, but he cast them in a different

\footnotetext{
${ }^{50}$ Chester Leonard, "Vardy Community School," 5.

${ }^{51}$ Chester Leonard, "Vardy Community School," 6.
} 
light saying that there must be connections for the students to real life situations or to values that were undeniably important. Dewey classifies topics as either immediate or instrumental: immediate being those of direct interest and relevance and instrumental being those topics studied because of some end beyond themselves. Wrote Dewey, "In general what is desirable is that a topic be presented in such a way that it either have an immediate value, and require no justification, or else be perceived to be a means of achieving something of intrinsic value. An instrumental value then has the intrinsic value of being a means to an end. ${ }^{52}$ Leonard's curriculum demonstrates how the important connections to real life could be incorporated into school tasks.

Another tie to Dewey's pedagogical recommendations was Leonard's insistence on realia rather than textbooks to promote learning. Dewey saw reliance on texts as a worn-out form of Scholasticism that dated from medieval university methods. He saw this Scholasticism as stifling, causing teachers to be constantly explaining outdated material.

Where literature [meaning received texts] rather than contemporary nature and society furnishes material of study, methods must be adapted to defining, expounding, and interpreting the received material, rather than to inquiry, discovery, and invention. And at bottom what is called Scholasticism is the whole-hearted and consistent formulation and application of the methods which are suited to instruction when the material of instruction is taken ready-made, rather than as something which students are to find out for themselves. So far as schools still teach from textbooks and rely upon the principle of authority and

\footnotetext{
${ }^{52}$ John Dewey, Democracy and Education, 242-3.
} 
acquisition rather than upon that of discovery and inquiry, their methods are Scholastic — minus the logical accuracy and system of Scholasticism at its best. ${ }^{53}$ Leonard clearly accomplished school without textbooks with one exception. Committed himself to the truth and value of Scripture, what he obviously did not see was that Dewey's idea carried to its logical extension would negate the value of the Bible, the received text upon which many of the principles of his ministry as well as the foundation of the worship services he led and classes he taught (both on Sunday and as a school subject) rested. With the exception of Bible, he was committed to using found artifacts of the natural world and the society as teaching tools.

\section{STAFF AT THE SCHOOL}

One of Leonard's policies was radical for his era, a time when elementary school teachers particularly in country schools often did not even complete high school before they started teaching themselves. He insisted that all full-time teachers at Vardy have work towards a Master's Degree. In addition to Miss Rankin there were two people who were important partners in Leonard's incarnation of the ideal school for mountain children: Drew and Alyce Williams. Alyce Horton was a granddaughter of Batey Collins. Her mother Adelaide married Dan Horton, a man ten years her junior who came to Vardy after the Spanish American War with a Vardy boy, Wiley Gibson. Dan Horton was an energetic addition to the Vardy community; he owned a mill and a store in addition to farming the land that Adelaide inherited. Alyce, born in 1909, went to boarding school in Asheville at the Presbyterian schools. Later her father moved his family to Ewing,

\footnotetext{
${ }^{53}$ John Dewey, Democracy and Education, 280.
} 
Virginia, where she finished high school. She continued her education at Lincoln Memorial in Harrogate, Tennessee, where she met and fell in love with Drew B. Williams from Jellico. Alyce taught at several one-room schools in Hancock County including Elm Springs about four miles west of the Vardy Presbyterian Center. Alyce began teaching the primary class at Vardy when Miss Rankin retired and continued until the Williams family moved to Knoxville in 1957.

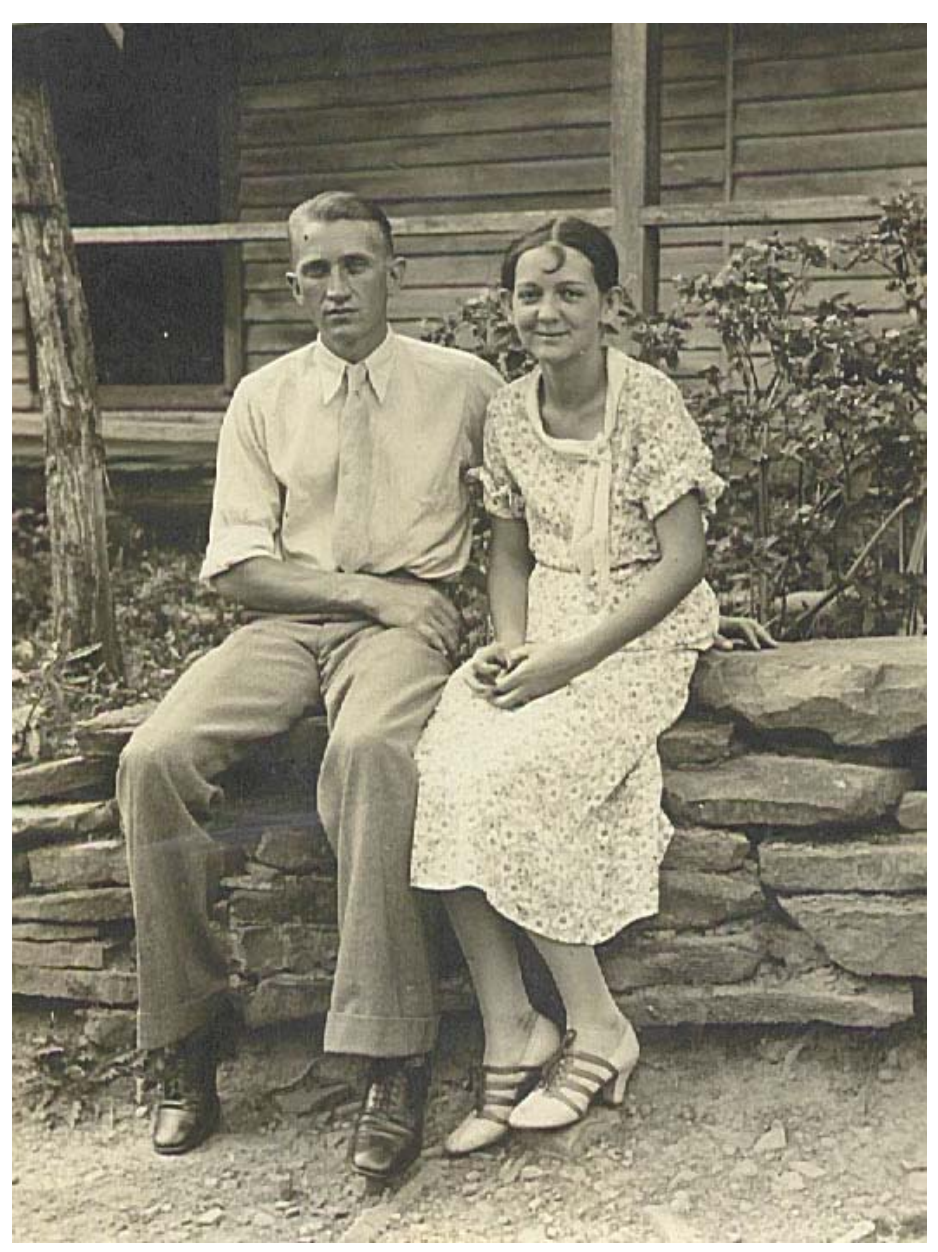

Drew and Alyce Williams, life-long educators, taken in the 1930s. Both taught at Vardy. Alyce was the daughter of Adelaide Collins and Daniel Boone Horton, granddaughter of Batey Collins. Drew and Alyce are the parents of DruAnna Williams Overbay.
Drew B. Williams, born in 1907, was a campus leader at LMU where he and his roommate Jesse Stuart, led a student demonstration. Drew was dismissed; Stuart stayed to graduate. The two were life-long friends. Daughter of the Legend was inspired by Stuart's association with Drew and Alyce and the Melungeon girl from Hancock County whom he dated. Williams graduated from Berea and started teaching at Vardy immediately. Chester Leonard insisted that he begin a Master's Degree at the University of Tennessee in accordance with the Vardy School policy stating that faculty 
should have graduate work above the Bachelor's level. Williams was an able teacher of the upper grades (5-8) and grew under Leonard's tutelage into a position of leadership. He left the Vardy School for even more responsibility when he was elected Hancock County Superintendent of Schools in 1942. Leonard relinquished the Vardy Community School to the Hancock County System in 1944; this might have been made easier by the fact that he was turning the fruit of his labor over to a trusted friend, Drew B. Williams.

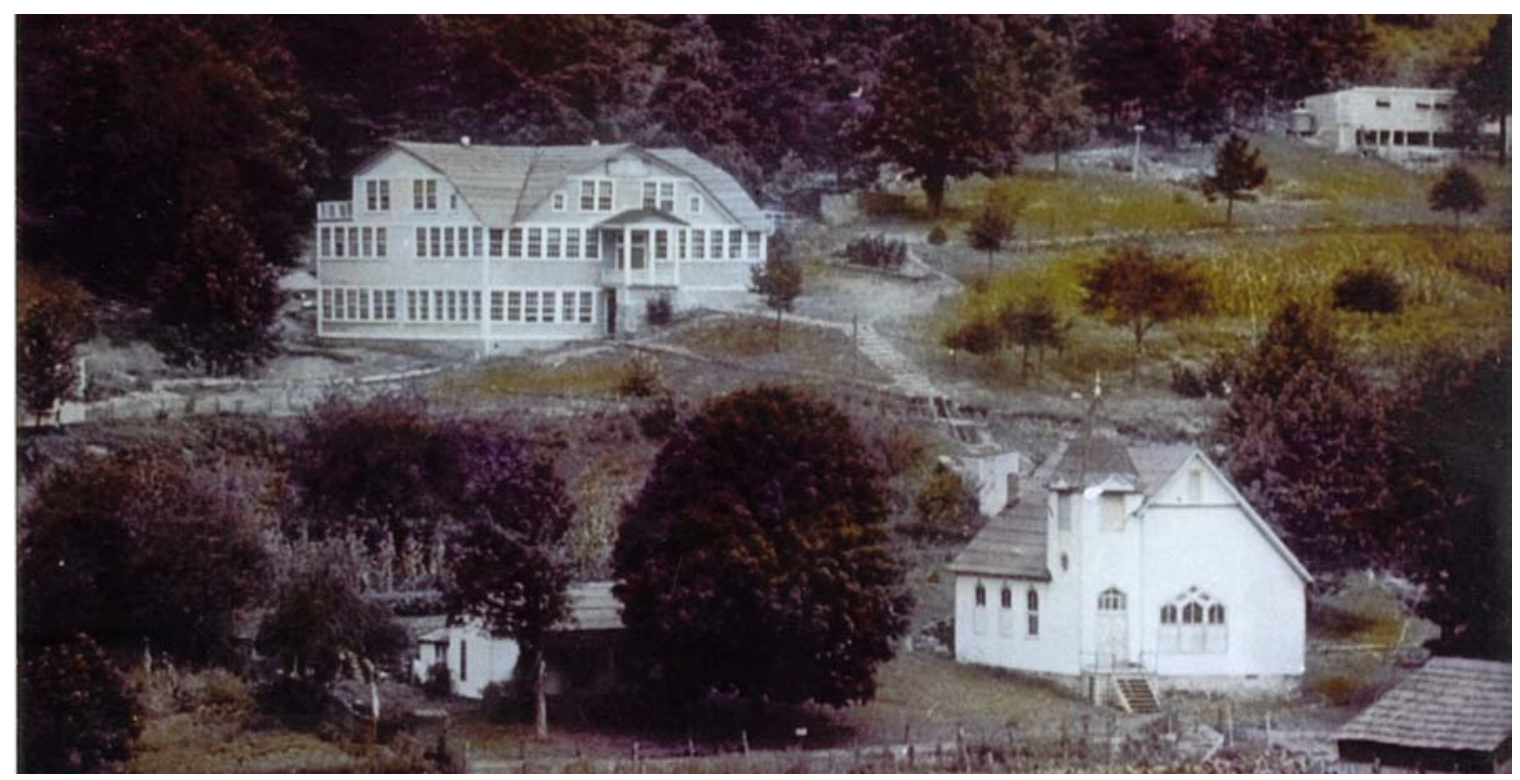

Vardy Presbyterian Center, between 1929 and 1933. The first "teacher's house" to the left of the church was destroyed in the tornado. The building upper right is a chicken coop.

Leonard hired some local women, who did not have college training, as teacher's aides; Stella Miser and Eliza Goins were two who contributed for many years. In the 1940s, after Drew Williams left, Helen Stewart Mullins taught the upper grades; she was the first Vardy alumna to finish college, graduating from Maryville. Another teacher that many students remember was Mossie Kate Overton; she left a rich archive of anecdotal material about school life during her tenure in the 1940s as she had the students write 
articles that appeared in the local newspaper and correspond with soldiers and sailors away from Vardy during World War II.

\section{THE KINGDOM OF GOD ON EARTH AND THE ABUNDANT LIFE}

Leonard's early reading of Rauschenbusch led him to Bible passages that talked about a better life in the here and now. His passion for his phrase "Abundant Life" can be traced to a verse in John's Gospel where Jesus proclaims, "I am come that they might have life, and that they might have it more abundantly.",54

Reading Dewey's Democracy and Education would have affirmed the idea that science is what will break the cycles of disease and poverty. Leonard's conviction that his ministry should touch all facets of community life is a logical outgrowth of his reading of Dewey and Rauschenbusch and is nowhere more evident than in the area of medical practice. Miss Rankin's early emphasis on providing health care for Vardy residents was maintained and broadened by Chester Leonard. Together the missionaries worked to not only provide care and medicines, but also to educate the people about sound health practices. There was a small building behind the manse where medicines and supplies were kept and treatments were administered. Children stopped at this "clinic" on their way up the hill to the school to take medicine that had been prescribed for a sickness, to be checked for lice, or to have a wound dressed. Leonard and Rankin held community health sessions they called "clinics" to inform people about certain maladies, to teach proper health practices, and to administer appropriate treatments. Leonard's annual report for 1932 noted that two clinics were held for people who needed dental care: "A total of

\footnotetext{
${ }^{54}$ John 10: 10, King James Version.
} 
87 were examined, mostly school-children. Several teeth were extracted. Advice was given to others as to the care of their teeth. If that advice is followed, I am sure that the clinics were worthwhile. ${ }^{, 55}$ Ruth Muhlbauer commented in her Oral History Interview that before Mr. Leonard began his clinics toothbrushes and toothpaste were unknown, "We didn't brush our teeth before then. We would clean our teeth by chewing on a willow switch with the leaves still on it. Really, it did taste good and did a fairly good job. ${ }^{.56}$

In 1935, Leonard noted in his yearly report, "Early in December of '34, we held our last clinic for the prevention of typhoid with 246 taking the treatment. With typhoid in various places about us, we did not have a single case. ${ }^{.57}$ The clinics were so popular and appreciated that people from nearby communities began to seek access. Leonard and Rankin were an impressive team. Audrey Mullins Franz related, "Preacher Leonard and Miss Rankin treated everybody so good. If we were sick, they would give us some pills to make us better. We would stand in line in the assembly room to get vitamins and cod liver oil to keep us healthy. We all took our medicine and didn't argue that we didn't want to take it. We trusted them to treat us and keep us healthy because they did everything for us. ${ }^{, 58}$

Better health was not the only benefit to the community from Leonard's concept of the "Abundant Life." The school library was open to adults who gradually began to borrow books and magazines more frequently. The wonderful new building was a magnet for everyone. In the early years, formal classes were held for adults, and later a program

\footnotetext{
${ }_{55}^{55}$ DruAnna Overbay, Windows on the Past, 55.

${ }_{57}^{56}$ Ruth Jenkins Muhlbauer, Oral History Interview, quoted in Windows on the Past, 55.

${ }^{57}$ DruAnna Overbay, Windows on the Past, 56.

${ }^{58}$ Audrey Mullins Franz, Oral History Interview, quoted in Windows on the Past, 58.
} 
of "community nights" was adopted that offered programs once a week during the eightmonth school term. Guests from colleges such as Berea and government personnel like the county agricultural agent rounded out Leonard's schedule for the entire population. Topics included agricultural practice, travel, history, and current events.

Leonard's seriousness about the well being of the community is apparent in various reports that have been preserved by the Vardy Museum and by some individuals in the Sneedville area. One report from 1930 for the New Tazewell Enterprise Group touches on school attendance, an upcoming adult night school, and a list of children who were vaccinated against smallpox and diphtheria. ${ }^{59}$ Another report, photographed and printed in Windows on the Past, lists the lunches served at the school in the 1942-43

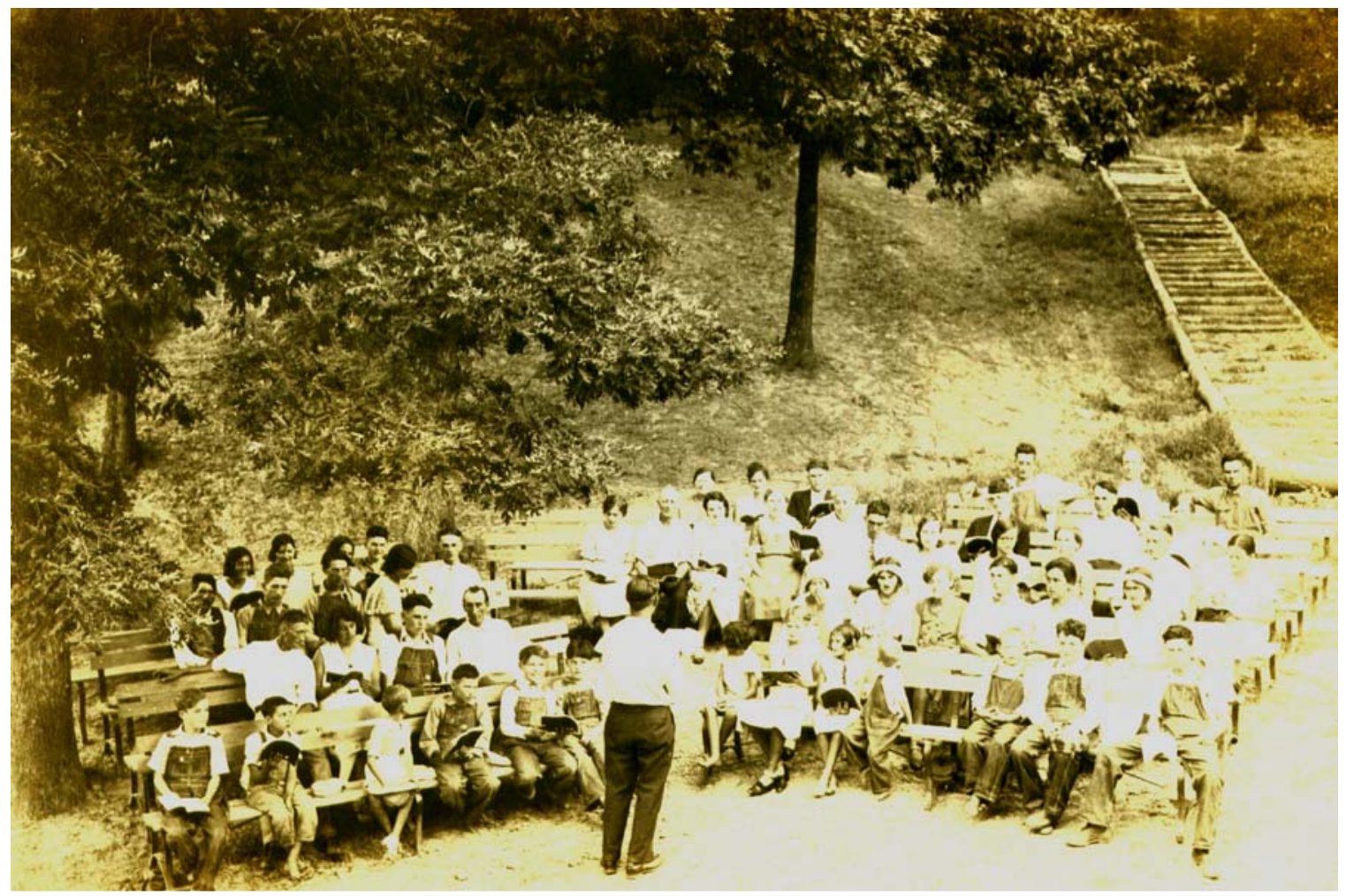

Leonard giving an outdoor lecture. DruAnna Overbay thinks this was probably a Sunday afternoon teaching time. Many community residents are recognizable in this photo taken out a window of the school building.

${ }^{59}$ Vardy Voice, October 2003, 2-6. 
school year. ${ }^{60}$ This typed report tells not only how many meals were served, but also how many pounds individual students gained and how much taller they grew.

How did one man keep up this pace? In the tradition of mission work, the sabbatical year or furlough time is a strategy used both to rest and re-energize the workers. Church records show that Leonard was gone for at least two years, 1926-27 and 1938-39. Swartz reported that Leonard did two extended courses of study to enhance his ministry at Vardy: one was a time in Nashville learning about electricity and generators to facilitate the electricity set-up that he put into place in the new school building, and the other was time at Johns Hopkins studying medicine in order to serve the health needs more effectively. Both Chester and Josephine Leonard, and presumably Mary Rankin, attended summer leadership training institutes at Presbyterian colleges like Maryville and Warren Wilson. Leonard also traveled to visit supporting churches in New Jersey. According to Swartz, during his year in Vardy there were several times when professors from various colleges came to Vardy and offered "Opportunity Schools" for the community. These visits must have provided stimulating conversation and discussion of current academic topics; Leonard noted that one of the guests was theologian Richard Niebuhr.

Swartz reported that Leonard had a very active intellectual life. He had a remarkable study, a porch with windows along one entire wall that was added to the Manse at the time the school was built. Every evening after dinner and the 6:00 news on the radio, he would retire to his study to read and write. It is apparent that Leonard did not let isolation in Vardy limit his intellectual contacts in the outside world.

\footnotetext{
${ }^{60}$ DruAnna Overbay, Windows on the Past, 151.
} 
There was an expectation from the Board in New York City that the Presbyterian community workers would do everything they could to effect economic and social progress in the counties where they were assigned. This expectation was also spelled out in Leonard's commission to serve at Vardy. One very interesting letter exists that Leonard wrote in 1930 to the local newspaper to advocate for improvement of the roads to and in the valley. Leonard argued that the church, the school, and the county would all benefit if the roads were better. He complained that getting to Sneedville was nearly impossible much of the year and that the $\$ 21,000$ that had been spent in Vardy in the previous year, the year the school was built, went to merchants in Virginia, Kentucky, and even Chicago, because those places were more accessible to Vardy residents than their own county seat. In addition, he noted that Vardy voters were all but disfranchised by their isolation, never getting any visits from county officials save at election time. ${ }^{61}$

One aspect of middle class life that came to the mountains by virtue of the settlement school movement was the celebration of recognized holidays, especially Christmas. Christmas in the mountains before the arrival of the "fotched-on" women had meant little except a day for men of the community to drink to excess and spend a day riding around discharging firearms in celebration—-drinking and shooting. In an article in Mountain Life and Work, Chester Bower speaks of two general classifications for recreation: one is a leisure of escape. The second he terms "leisure of fulfillment." The missionaries and other mountain workers sought to turn what had been recreation to escape the harsh realities of subsistence living through the artificial stimulation of alcohol into something positive. They brought with them traditions like decoration with

\footnotetext{
${ }^{61}$ Vardy Voice, March 2003, 10-13.
} 
evergreens, the Christmas tree, and gift giving. Miss Rankin introduced a Christmas celebration to the Vardy Valley that included a big tree in the church hung with gifts for every child. After the Leonards arrived, the tradition continued with a small box of hard candy for each youngster in addition to a gift selected from boxes the supporting churches sent. Miss Rankin and Mrs. Leonard would confer with parents to determine what each child needed most—clothing, a book, or perhaps a toy. Vardy Community Historical Society member R. C. Mullins told the story he called "My Hard Candy Christmas":

On this day Preacher Leonard would tell the Christmas story, and we would have plays and programs performed by the children. I could hardly wait till it was over so we could get our Christmas. The little box of hard candy was what I had waited for. I had not had any since last Christmas. My dad worked hard, but some days he worked all day for a dollar or less. There was not much work to be found in those days. So candy was a luxury we couldn't afford.

When I got my box of candy, I hurried outside so I could open it. As I looked inside at all the pretty colored pieces, I took out one and placed it in my mouth. M-m-m, how good it was. I didn't dare bite into it, for I wanted it to last a long time. ${ }^{62}$

As outlined in an earlier chapter, one of the hallmarks of the culture in Vardy has been the struggle against destructive behaviors such as abuse of alcohol and promiscuity. I asked David Swartz if he and Mr. Leonard had ever acknowledged the problems and, if so, how Leonard dealt with them. Swartz responded,

${ }^{62}$ R. C. Mullins, "My Hard Candy Christmas," in Windows on the Past, 157. 
Violence was an issue. Moonshine and guns contributed. Political alliances, jealousies, and family feuds or negative memories instigated some of the strife.

Mr. Leonard was a teetotaler. He stressed good health practices including the avoidance of liquor and tobacco products including snuff. Mr. Leonard was involved in at least one violent episode at Christmastime in the church-a man was killed. ${ }^{63}$

Mr. Leonard countered practices he considered destructive or immoral with personal virtue and with conscious appeals to the biblical paradigms of orthodox Christianity. $\mathrm{He}$ provided consistent worship experiences that any Presbyterian would have deemed "decent and in order"-well-wrought sermons and school talks, leadership in hymn singing (Leonard played the small organ at the church), beautiful flowers on the communion table (from Mrs. Leonard's extensive outdoor garden and her hothouse). However, given the old codes of behavior and indigenous religious beliefs, it is doubtful that Leonard's methods were efficacious.

There is no record of how the missionaries felt about the tangled sexual relationships of many of the valley adults. Swartz told me:

Intermarriage, adultery, incest, separation, and divorce were common references to some of the individuals or families when I was at Vardy. Some of the identities were unspoken. I just didn't let the past prejudice my relationships nor trigger my curiosity. ${ }^{64}$

\footnotetext{
${ }^{63}$ David Swartz, Email message to Katherine Vande Brake, 25 October 2003.

I'm not sure which incident Swartz is referring to. The Mathes Goins incident to follow was not at Christmastime.

${ }^{64}$ David Swartz, Email message to Katherine Vande Brake, 25 October 2003.
} 
My conversations with residents and former residents indicate that a similar set of social mores still predominate in the area, although the easy availability of birth control has meant that families are much smaller; adulterous relationships now rarely produce children.

Even though the Vardy Presbyterian Church records are mostly limited to mundane transactions of ecclesiastical business, there are hints there of dark and dangerous events.

August 6, 1922 - Harry Collins tried to shoot Mr. Leonard.

June 21, 1925 - Henley Collins shot.

September 9, 1930 - Lee Mullins murdered.

February 11, 1931 - Mathes Goins, drunk, shot dead on the school steps. ${ }^{65}$

Leonard certainly encountered social problems for which neither his education at

Maryville College nor his seminary training had prepared him. His tenacity and

dedication to the young people of the valley, who could both be transformed and become transforming in one generation, show his character and faithfulness to his call.

\footnotetext{
${ }^{65}$ This last item wants comment. Mathes Goins was the husband of Eliza Goins, a teacher's aide at the school. I do not know who shot him or why. However, one of my informants showed me a computerprinted picture taken in the last couple of years. This photo shows the by-then-dilapidated Vardy School building at night with an image of Mathes Goins' ghost. The ghoulish figure with most of its face shot away is recognizable in the image I was shown. My informant told me that the person who gave her the picture was certain that it was authentic and that the ghost of Mr. Goins does inhabit the scene of his untimely death. More important than whether this image was doctored in a photo editing software program is the fact of belief. The old literacy of superstition about "haints" and vengeance is still current in the Vardy valley notwithstanding more than a hundred years of outside influences - the teaching of reading, writing, and thinking skills and Christian doctrine dispensed in Sunday School doses.
} 


\section{DAVID SWARTZ AND THE END OF A FINE ENDEAVOR}

Although he probably didn't realize it at the time, Dave Swartz was the last hope for the

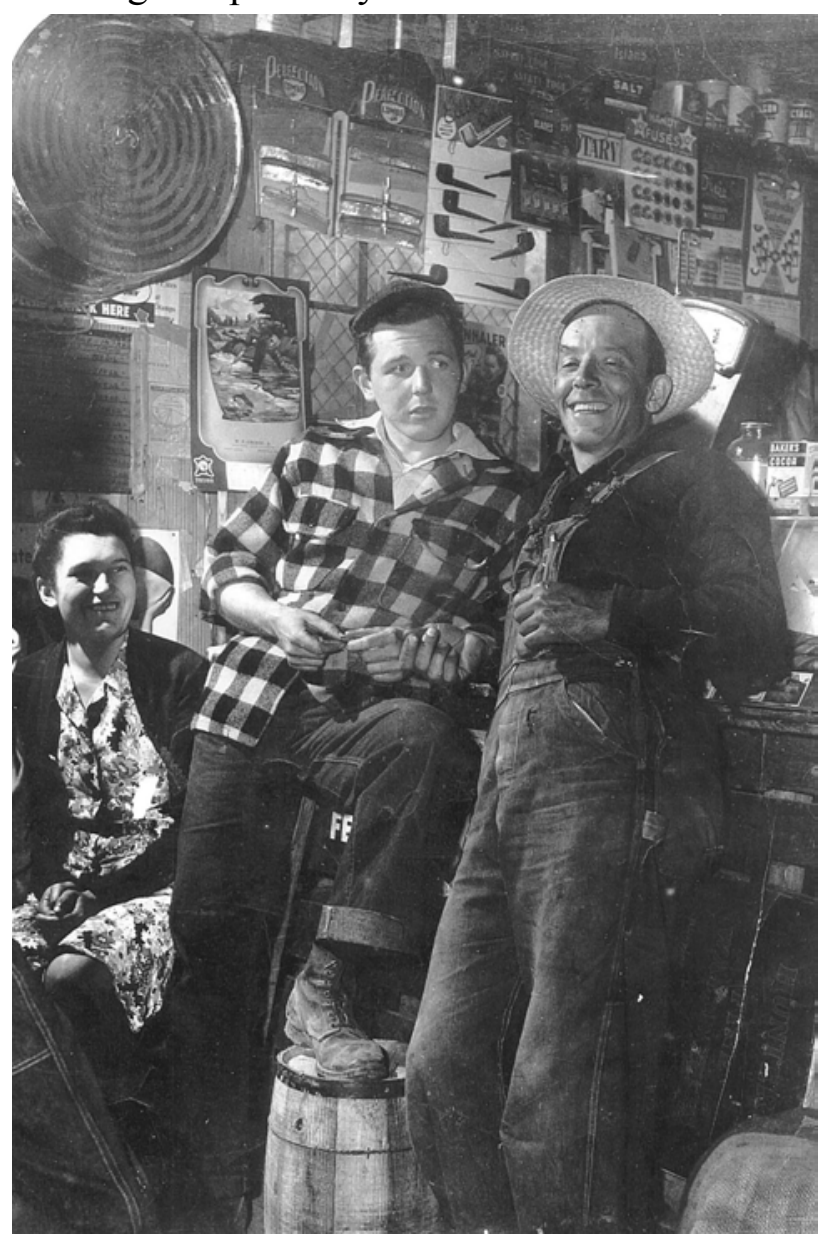

David Swartz is shown in the center with Bill Grohse at Grohse's store in 1946-47. Grohse, who married Lillian Miser (daughter of Nancy Collins Miser, granddaughter of Batey and Cynthia Collins, became the valley historian and genealogical expert. continuance of the Vardy experiment in

its comprehensive form. Miss Rankin

left Vardy in 1943 and moved to

retirement in Florida. She came back

for a few years in the summers to help

with various programs at the church

like Bible School, but her quiet

leadership, her careful teaching of the

youngest children, and her medical

service were over. The graveled road

from Sneedville gave a doctor access to

the valley for birthings, and the school

was officially taken over by Hancock

County in 1944. Swartz states

repeatedly that the Vardy Mission was

extraordinary in many ways, not the least of which was the camaraderie between the primary workers: "[Miss Rankin] and Mr. Leonard had an unusually positive relationship and respect for each other. This was not always true in Presbyterian aided-fields where 
the minister arrived years after the school teacher/missionary lady first made her home in the isolated community. ${ }^{\prime 66}$ Losing Miss Rankin must be seen as the beginning of the end.

Mr. Leonard's health was deteriorating. Although Swartz makes no mention of Mr. Leonard being ill, Swartz had not known Leonard earlier when his health was better. Swartz's perceptions about Leonard and the Vardy mission provide valuable insight into Leonard's beliefs and values. When questioned, Swartz reported that for Leonard the phrase "Abundant Life" meant many things including the spiritual dimension of his work. Comments about how Leonard carried out his ecclesiastical responsibilities are interesting and informative.

By the time Swartz went to Vardy in June of 1946, the school was already in the hands of the county board of education. "We are not trying to drive out the county teachers," Leonard had written in 1928. "Just as soon as they can meet our standard the regular school work will be returned to the county." ${ }^{~} 67$ This course of events was exactly what Samuel Wilson described in The Southern Mountaineers. I have to admit that before I read Wilson's book, from my interviews with Vardy graduates, I perceived the hand-off to the county to be caving in to political pressure because it seemed that the quality of the enterprise began to deteriorate once the county took over. Swartz reported to me, "In '46'47 Mr. Leonard did not have the primary responsibility for the Vardy Community School. At that time the Hancock county School Board through the county superintendent, Drew Williams, recruited, trained and monitored the teaching in all the schools including Vardy. Chester and Josephine Leonard and Chester's father were

\footnotetext{
${ }^{66}$ David Swartz, Email message to Katherine Vande Brake, 22 October 2003.

${ }^{67}$ Chester Leonard, "Helping a Community," 17.
} 
resources that the superintendent could rely on to bring enrichment to the school program." ${ }^{68}$

Swartz himself describes the hiring by Drew Williams of two girls who had graduated from high school in Sneedville the previous May to be teachers in the elementary school at Vardy. I'm quite sure that by that time, 1946, the curriculum had been regularized to match what was being offered in other county schools. Leonard was doing little at the school— just teaching Bible classes, supervising in the lunchroom, staffing the library periods for the students, and running the first aid groups every school day. By 1946, most of Leonard's responsibilities were at either the church or a part of what could rightly be called the "community center" aspect of the ministry. Swartz said that Leonard presented the Christian faith and the Presbyterian representation of it as "a viable extension of 'learning' plus the unique teaching of 'sacrifice' and 'forgiveness.' Church membership was as 'opportunity' not a 'requirement' for participation in common ventures on behalf of the larger community. ${ }^{, 69}$ Swartz remembers Leonard as a 'can-do' man with theological training. He emphasized the concrete along with the abstract. He welcomed and taught Jesus' parables. He emphasized moral behavior, resourcefulness and persistence. He did not neglect the spiritual but he was more concerned, as I was, for all to become laborers in the Kingdom here on Earth rather than to sit by idly and irresponsibly awaiting the gift of the Kingdom of Heaven. ${ }^{70}$

\footnotetext{
${ }^{68}$ David Swartz, Email message to Katherine Vande Brake, 4 November 2003.

${ }^{69}$ David Swartz, Email message to Katherine Vande Brake, 25 October 2003.

${ }^{70}$ David Swartz, Email message to Katherine Vande Brake, 25 October 2003.
} 
This is Rauschenbusch's vision for a new social order realized in a narrow Appalachian valley.

Young Swartz was impressed with his mentor, whom he saw as inspired in his work at the Vardy Center. Swartz was amazed by what Leonard could accomplish even though he was nearing the end of his time at Vardy: "I recall no time when Mr. Leonard was unprepared or shared a difficult or tedious exposition of scripture. ${ }^{, 71}$ When I asked about what Leonard believed to be most important from a theological point of view, Swartz admitted no direct knowledge but said he guessed that "[Leonard] believed Jesus of Nazareth to be God incarnate-fully human, fully divine. However, he stressed the 'moral influence theory' of Jesus as a man who taught, preached and healed those despised, neglected, poor - those living in confusion, pain, or ridicule. Mr. Leonard's life mirrored those interests and his ministry those human conditions." ${ }^{72}$ So, even thirty years after his time in seminary, Leonard was still articulating clearly kernels of Rauschenbusch's social gospel theology.

Even though Swartz's memories are overwhelmingly positive, the church records hint at darker truth. The optimism and excitement that come through so strongly in Leonard's publications in the Presbyterian Advance in 1928 and in Mountain Life and Work as late as 1938 are missing from some of the pieces that Leonard wrote to be included in the Session Meeting Minutes. In 1929, the year the new school opened, the annual community Thanksgiving dinner had more than 200 people attending. By 1940 the church records lament declining attendance at Sunday School and worship, and there are recurrent notes about purging the church roll of inactive or absent members.

\footnotetext{
${ }^{71}$ David Swartz, Email message to Katherine Vande Brake, 25 October 2003.

${ }^{72}$ David Swartz, Email message to Katherine Vande Brake, 25 October 2003.
} 
On August 17, 1941, a special meeting of all church members was called.

Leonard, in effect, offered to resign; he read this question to the assembled congregation: "Do you, as a member of the Vardy Community Church, wish for this work to continue as it has been carried on, or do you think that it would be better to change its way of working and the things for which it has been standing?"73 The minutes go on to say that Leonard read some statements about the work of the community center and then left so that the members could have an open discussion. Of course, there was an overwhelming vote of confidence. But, what could have prompted the resourceful and usually confident Leonard to offer his resignation? Swartz noted that in his time working at the Board of National Missions in New York he found some letters written by disgruntled family or families asking that Mr. Leonard be removed from his position at Vardy. Perhaps Leonard had wind of such a letter and wanted to clear the air. It's hard to believe that he was really serious about giving up his position as early as 1941 .

In September of 1947, very soon after Swartz departed to return to his studies at Union Seminary in Manhattan, Leonard implored the Elders and Deacons of the Church to help him.

I have called this meeting of elders and deacons because we are in a very difficult position; I might say; a dividing of the ways. ...

When our Community Program was in the building we had considerable help. Today I am the only leader left. Father cannot take care of the buildings and grounds as he once did; our teachers are hired by the County and, therefore, I cannot ask them to help in community leadership as a duty. Miss Rankin is here

\footnotetext{
${ }^{73}$ Vardy Presbyterian Church Records, 17 August 1941.
} 
for a short visit. Richard Niebuhr left yesterday. I am no more able to work as I did for so many years....

Only two afternoons this past week did I have my periods of rest. They cut into my day but are absolutely necessary every day. I have been told that unless I cut down work and responsibility that I shall be a semi-invalid within two years. ${ }^{74}$ The Session of the Church planned a celebration for the spring of 1948 to recognize Chester Leonard's thirty years of service to the Vardy community, but the party was never held. Leonard came back to the church board on April 15, 1948, and presented his letter of resignation. In his long letter he lamented his departure, and, always the teacher and still true to his articulated goal, he exhorted the board members to care for the buildings and programs of the Vardy Community Center. Wrote Leonard,

The doctor has repeatedly warned me that I must stop work for a time. For three years I have not heeded that warning and now I have come to the place that I cannot more add to your welfare; in fact, I can hardly get to services. . . .

I am sorry that I cannot say: GOOD-BYE, but that will take too much of my strength and hurt too much. As you know, I have loved all of you as if you belonged to my family. My great sorrow is that I have been able to do so little for so few. I know how Jesus felt when He wept and said: I WOULD HAVE GATHERED YOU AS A HEN GATHERS TOGETHER HER CHICKENS to protect and to help; but I could not because many have not wanted what I could offer. ...

\footnotetext{
${ }^{74}$ Chester Leonard,"Meeting of Elders and Deacons of Vardy Community Church,” 14 September 1947.
} 
During the past several years I have tried to get some one to come to help me and to be trained for your future leadership. No such person has been found. . . I have given the best of my life to you. ${ }^{75}$

David Swartz was certainly one in whom Leonard invested much, hoping that Swartz would pick up the mantle at Vardy. Even though Swartz is open about the fact that he did not choose East Tennessee for his intern year (he requested an assignment in the Northwest), his time with Chester Leonard must have sparked his interest in home mission work; his 1950 thesis was titled "The Philosophy of Evangelism of the Board of National Missions in the Southern Mountains.” Swartz did go to work at Burnsville, North Carolina, for five years, and after that spent another five years in the New York office of the Board of National Missions as the Youth secretary.

Although Leonard did leave for a time in 1948, there was no one to replace him. Session minutes note, "A motion was made to send a petition to Dr. Randolph asking him to help in having Mr. Leonard return to Vardy if and when Mr. Leonard's health permits. ${ }^{, 76}$ A year later Leonard was back in Vardy doing as much as he couldconducting worship services, leading the singing, teaching Bible classes at the school. Some of the "community work" was picked up by members of the session, but some things fell by the wayside.

An endeavor that began many years before with a visit from sky-pilot Christopher Humble was coming to an end. Leonard's early "prophecy" about the work at Vardy contained both the truth as he saw it and a death knell. In 1928 he had written, "We shall

\footnotetext{
${ }^{75}$ Chester Leonard, Letter to The Officers and Members of Vardy Presbyterian Church, 15 April 1948. Capitalization copied from Leonard's original typescript.

${ }^{76}$ Vardy Presbyterian Church Records, 18 April 1948.
} 
never, as far as we can determine, be able to pay all of our expenses for civic and religious work, but as far as we are able we shall pay all that we can for everything worth while that we may receive." ${ }^{77}$ As his time in Vardy drew to a close, the optimism evident in the writing he did in his early years was replaced by solemn warnings and veiled threats to his church officers and the church members. In 1946, the year that Swartz was interning at Vardy, Leonard made the annual request for funds to the Board of National Missions contingent on answers to these questions:

1. How many will try to be at morning services every Sunday possible?

2. How many will keep order on the road? In meetings? And other places?

3. How many will work to get others to morning Bible School and worship service and treat them as you should when they come?

4. How many will see to it that the boys and girls now running wild in your families are controlled to act as they should?

5. How many of you will from now on try to act as you should on the road, in meetings, and other places? ${ }^{78}$

These are not questions that the younger man, who was taking a careful survey and sitting back for a year to digest the survey data, would have posed to Vardy residents. Leonard knew that both the playing field and the rules had changed. Things were out of his immediate control.

A letter from Josephine Leonard to Dave Swartz in 1951 reveals that the window of opportunity at Vardy was about to close,

\footnotetext{
${ }^{77}$ Chester Leonard, "Helping a Community," 17.

${ }^{78}$ Vardy Presbyterian Church Records, 8 September 1946.
} 
We shall formally tell the folks on the $30^{\text {th }}$ that we are going to leave at the end of October. ... How they will find anyone to come seems a problem. Miss Carson and Mr. Glasse [from Warren Wilson] feel that it will be a 'calamity' not to have someone here.

Chester went to the doctor two weeks ago. The doctor expressed surprise — said he did not expect to see such improvement in anyone.... Said he should get to level ground and avoid heavy responsibility and that in another six months he should be getting over emotional strain, but that he would never be free of that in Vardy. How true! $!^{79}$

By the time of Josephine Leonard's next letter in February of 1952, Leonard was dead of a "massive occlusion." Leonard was gone. The "social community with a religious basis" would never be the same.

Church elders Drew B. Williams and William P. Grohse tried hard to keep the church going, but it never was able to operate without yearly infusions of cash from the Board of National Missions. Matters as mundane as maintaining the church and school property and mowing the grass were concerns in letters that traveled back and forth from the Board in New York and the men at Vardy. Several churches in the Midwest sent summer mission trips to Vardy to help with painting and other maintenance chores. The Church Records continue to record struggles to staff Sunday School and carry on the rudiments of what had been a thriving enterprise under Leonard's hand.

Miss Louise Avery came to Vardy in 1958 at the behest of the Board of National Missions. Both the church and the school were in disrepair. Classes had been

\footnotetext{
${ }^{79}$ Josephine Leonard, Letter to Dave and Virginia Swartz, 20 September 1951.
} 
discontinued at the school. Miss Avery worked almost single-handedly to clean the building and get rid of the mice that infested the rooms. Classes resumed at Vardy Community School; Avery, Arnold Johnson, and Elmer Turner were paid by the county to teach at Vardy. Avery lived in the manse and resumed some of the community work by getting a "Vardy Community Club" started to encourage neighborhood pride. The school stopped operating in 1973, when the children were all bussed into Sneedville as consolidation finally reached the Vardy Valley. The Church records also stop that year, two of the last entries being these notations: " $1{ }^{\text {st }}$ United Presbyterian Church group (17) also built new steps at our church. Started 8/8 and finished 8/15/1973" and "Vardy Community Club won $1^{\text {st }}$ prize at East Tennessee Community Awards Banquet in Knoxville, Tenn. on December 8, 1973. ${ }^{, 80}$ An impressive example of a sweeping cultural intervention that elevated literacy practices to prominence was ended seventy-five years after it began. The Presbyterians gave the Melungeons of Newman's Ridge an educational advantage unmatched by the public schools; the pedagogies shaped people who went to Vardy Community School and continue to bear fruit.

\footnotetext{
${ }^{80}$ Vardy Presbyterian Church Records, 1973.
} 


\section{Chapter 5}

\section{Assessing the Vardy Experiment: Intervention in Culture and Sponsorship of Literacy}

\section{CHAPTER INTRODUCTION}

This chapter is an assessment of the Vardy experiment. Two scholars whose work mediates what happened at Vardy are David Whisnant, a key player in Appalachian studies, and Deborah Brandt, literacy theorist. Whisnant's book, All That Is Native and Fine, focusing on the Hindman and Pine Mountain settlement schools and the White Top Festival, explores the ideologies and practices of Appalachian workers in the first four decades of the twentieth century. Although he is not looking specifically at Vardy, he creates a yardstick by which to measure settlement and mission work in the Southern mountains within the timeframe of the Presbyterian uplift project in Hancock County, Tennessee.

Brandt in her 2001 book, Literacy in American Lives, develops the concept of the significance of the sponsorship of literacy. This idea is a refinement of her work on the importance of the social context in Literacy as Involvement. Wrote Brandt in 1990, "Learning to read and write depends critically on immediate social involvements with people who read and write and who can show you how the work goes."1 She reemphasizes in the later book that learning to read and write is as much about teachers,

\footnotetext{
${ }^{1}$ Deborah Brandt, Literacy as Involvement: The Acts of Writer, Readers, and Texts, Carbondale and Edwardsville, IL: Southern Illinois University Press, 1990, 32.
} 
role models in school and at home, and other conditions in communities as it is about decoding, penmanship, or composition. According to Brandt, people and institutions can form a climate that fosters and values written communication. Without such a climate literacy cannot flourish. Rankin and Leonard were sponsors who provided such a climate at the Vardy Presbyterian Center.

This chapter also looks at Vardy in the context of all the "mountain work." As I have already noted, some missions were being abandoned at the time Leonard was getting started. His success is even more noteworthy against this backdrop.

In Vardy, student and families responded to the new situation introduced by the school and the church in several ways. Three distinct groups of Vardy school alumni are evident. Their stories lead to my conclusions: significant cultural change is complex and being Melungeon has profound consequences that literacy can neither efface nor erase.

\section{THE START OF THE VARDY EXPERIMENT}

Christopher Humble, the Presbyterian reconnaissance expert, probably had a gut response to what he observed among the Melungeons that was similar to Will Allen Dromgoole's descriptions. They were both middle class nineteenth-century professionals. As she had in the 1880s, he in the 1890s saw people living in small rude dwellings on subsistence farms in a narrow valley. The roads into the valley were poor. There was no access to any kind of professional medical care. Few manufactured goods were in evidence. Both described a meeting with a school teacher, who in each case taught his pupils in a oneroom log building. 
Dromgoole expressed herself in deprecatory hyperbole; she was a journalist hoping to sell her story. Humble had a different agenda. He was looking for a place to found "an uplift agency," and Vardy met his criteria. There was obvious need for a new school, better sanitation, basic health care, and (to his way of thinking) enlightened theology. The Presbyterian Home Mission Board Humble represented stood ready and able to provide all these things the community apparently needed and more.

The missionary enterprise based itself on a perceived "mountain problem." While the churches admitted there were economic factors and political situations that had bearing on social conditions, they claimed they had no power to change the economy of the region and no influence in local politics. The mountain culture was the sphere they chose to penetrate. According to scholar David E. Whisnant the missionaries were circumscribed by their own definition of culture as the special concern of women and ministers, two groups outside the power center of society. Whisnant defines "cultural intervention" to be when "someone (or some institution) consciously and programmatically takes action within a culture with the intent of affecting it in some specific way that the intervenor thinks desirable." ${ }^{.2}$ The missionaries, as their program was delineated by Samuel Tyndale Wilson, wanted outright transformation in the mountain communities where they served; they worked to effect changes in individual and collective behavior, social organization, forms of worship, school curricula, entertainment, sanitation practices, health care, holiday celebrations, and concepts of family, and theology. ${ }^{3}$

\footnotetext{
${ }^{2}$ David E. Whisnant, All That Is Native and Fine, Chapel Hill: University of North Carolina Press, 1983.

${ }^{3}$ List compiled from both Whisnant and Wilson.
} 
There is an important question embedded in this situation that no one stopped to ask in 1899: When a group of people is in obvious need, how can "helpers" give those people the best kind of assistance? ... what they need and no more? The answer to this question is no clearer today than it was a hundred years ago. At the turn of the twentieth century, the residents of the Vardy Valley did not enjoy many things that people in less isolated places took for granted. Dromgoole derided the Melungeons and made them an object of scorn and ridicule; she made no pretence of "doing good." Humble embraced the same group of people and locked them into a structure he used throughout the Appalachians; he had no doubt but that he was doing "good." By adding Vardy to his list of "missions," he insured certain fairly predictable results. In spite of the fact that the Vardy experiment was staffed by two extraordinary human beings, Mary J. Rankin and Chester Leonard, and the fact that because of them it became one of the very best examples of a mission school in any of the mountain states, there are, nonetheless, outcomes that bear examination.

The Presbyterians were thoughtful and sincere in their approach to the mountain work. They believed fervently in the value of what they were doing, the underlying reasons they had identified, and their methodology. Samuel Wilson would have subscribed whole-heartedly to the "myth of literacy" that Harvey J. Graff articulates, The rise of literacy and its dissemination to the popular classes is associated with the triumph of light over darkness, of liberalism, democracy, and of universal unbridled progress. In social thought, therefore, these elements relate to ideas of 
linear evolution and progression; literacy here takes it place among the other successes of modernity and rationality. ${ }^{4}$

This view of literacy is often called autonomous - meaning that literacy was seen as skills that are neutral and independent of any social context. Literacy is a commodity that equips people who possess it to accomplish important tasks in the future. The Home Missions movement assumed that bringing literacy to mountain communities would transform the mountaineers into middle class Americans with middle class values and aspirations.

Late twentieth century literacy theorists see the literacy landscape quite differently. They postulate that reading and writing are social practices embedded in a dynamic present. Literacy is a way of being that begets more and broader literacies. Deborah Brandt stresses the ties that bind readers and writers together in what she terms "the craft of literacy." She admits that there is a textual tradition, yet along side it are "generative social contexts in which reading and writing are practiced as part of everyday life.... Reading and writing survive," she maintains, "because they are embedded in so many diverse social practices, nurtured in talk, and valued as instrumental to various ends, individual and collective, which give them point and basis for renewal."

The story of the missionaries at Vardy can be viewed through the lens of late twentieth century literacy theory. There are many studies that talk about how literacy has been enacted in various communities. However, few of them start at "zero"—or little to no literacy - the way the Vardy story does. Rankin and Leonard not only taught the

\footnotetext{
${ }^{4}$ Harvey Graff, The Literacy Myth: Literacy and Social Structure in the Nineteenth-Century City, (New York: Academic Press, 1979), xv.

${ }^{5}$ Deborah Brandt, Literacy as Involvement, 126.
} 
students and the adults the basic skills of reading and writing, they also taught them how to operate in a world where reading and writing were the assumed medium of exchange. School had not been a priority in the valley before the missionaries came; it was a sometime-affair decidedly less valuable than the farming, distilling, hunting, and gathering that meant physical survival in a harsh environment. But, after 1920, when Leonard came, the context of a community that could support literacy became richer. The concord between Leonard and Rankin was a great advantage. The support of prominent land-owning families - the descendants of Batey Collins and the Burkett Mullins family—also enhanced the position the missionaries enjoyed. The geographical isolation was definitely a salient characteristic of the environment that in a positive sense protected Vardy from scrutiny and disruption. By 1930, the impressive school building and the three-level playground were a source of great community pride. However, even though there were advantages, the students brought their "Melungeon-ness" to school with them. That fact distinguished Vardy from other similar missions.

Deborah Brandt defines sponsors of literacy as "any agents, local or distant, concrete or abstract, who enable, support, teach, and model, as well as recruit, regulate, suppress, or withhold, literacy — and gain advantage by it in some way." ${ }^{\circ 6}$ According to Brandt, the interests of the sponsors and the sponsored may conflict because the sponsors control access to literacy. The story told later in this chapter about denial of access to school because of misbehavior is an example of control of access that happened in Vardy. The student's (or perhaps her parents') refusal to pay a fine imposed for misbehavior meant that the student did not return to school after the incidence of misbehavior. This

\footnotetext{
${ }^{6}$ Deborah Brandt, Literacy in American Lives, Cambridge: Cambridge University Press, 2001, 19.
} 
story illustrates Brandt's statement that "[s]ponsors are a tangible reminder that literacy learning throughout history has always required permission, sanction, assistance, coercion." 7

Leonard and Rankin, a powerful team, were very visible sponsors, or mediators, of literacy. Under their pedagogies Vardy children and adults augmented the vernacular literacies of the mountain community with the dominant literacies of twentieth century America. Leonard and Rankin were successful at blending new cultural practices with the old ways of the mountain people. They gave Vardy students the cultural capital they needed to be competitive beyond the valley. Leonard's words echo,

We do not beg them to stay, and we do not force them to leave. If they remain among us, we shall have provided leaders that will take the next generation another step or two up the ladder of progress. If they leave us and go into the other parts of the world, as we hope many of them will do, they will be better equipped to do their share of the world's work. ${ }^{8}$

How did the Vardy School effect such a transformation, from crippling illiteracy to quiet confidence? In fact, Vardy students grew to believe that texts had meaning for them and that they could participate in the world outside the valley. I think it was Leonard and Rankin's deliberate methods and faith in the students they were working with that were the primary factors. They made each small step do-able and celebrated every sign of progress.

\footnotetext{
${ }^{7}$ Deborah Brandt, Literacy in American Lives, 19.

${ }^{8}$ Chester F. Leonard, "Helping a Community to Help Itself," The Presbyterian Advance, 18 October 1928, 17.
} 
The old ways—-farming, logging, moonshining, and bartering — gave way to new practices at the community center campus that transformed students' and parents' expectations. Practices of reading and writing, a strict attendance policy, free health care, a system of mastery learning, meaningful play, plentiful nourishing food, definite behavioral expectations, manual training, sewing and cooking classes, opportunities for post-grammar school education at the mission boarding schools in North Carolina, and the possibility of going "away" to make a living were some of the things that came with the Vardy Community School.

In new literacy studies, writers talk of literacy events and literacy practices. A literacy event is a happening around a text; literacy practices are cultural ways of using reading and writing. I believe that what Mary Rankin and Chester Leonard did was enact and preside over literacy events in plain view, repeatedly. Gradually they built literacy practices into the value system of the community. These two literacy sponsors were highprofile models who wrote and read as easily as they breathed. They were committed to showing the Vardy community just how literacy could/should be done.

A list of Vardy literacy events would include the adult programs at the school, school programs at holiday times, Mrs. Leonard's story hours for the school children, Mary Rankin's mediation of agricultural practices through farm journal reading, and her letters to her family's doctor in Minnesota to learn how to treat various illnesses. Literacy practices that Vardy residents became aware of and accustomed to included Leonard's way of leading worship: a written sermon that he read to the congregation, hymns sung by reading the words in a hymnal, and music played on an organ according to Leonard's reading of a musical text. The mission also established a community lending library for 
children and adults. And, finally, Leonard relied on writing and its power in several very visible ways. He wrote letters to other scholars and to state and county officials. He composed reports for the church records and yearly summaries of the work that went to the Board of National Missions, and he submitted articles he had written for various publications. The survey that he did when he first arrived on the field is also an important use of writing. However, most people in the community would not have seen it or have known that it existed. Yet, it provided the basis for all that Leonard did.

Perhaps the most powerful literacy practice of all was the connection that was emphasized between real things—maps, timetables, advertisements, catalogs, travel articles, encyclopedias, and museum artifacts - to school learning. The team at Vardy did much more than teach students how to do textbook exercises; they jumped over that skill and taught life skills instead. Wrote Leonard, "We wish the students to learn how to use their tools and where to find them; then if the facts and items are forgotten, they are the more easily refound.... Our pupils come from homes where there are few books, papers, or magazines. Their background of world knowledge is therefore, very limited. To overcome that handicap, news is received daily by radio." ${ }^{, 9}$ Leonard and Rankin knew that just learning to read and write was not enough, and they realized that the measured pace of most textbooks was too slow to accomplish the miracle they needed. Only "real" things would take the students far enough. The children who profited from this pedagogy in the 1930s received, in many cases, much more than a typical elementary school education. Some of them like Helen Stewart Mullins, Ruth Jenkins Muhlbauer, and Claude Collins succeeded in high school and post-secondary schooling. Others like

\footnotetext{
${ }^{9}$ Chester F. Leonard, "Vardy Community School," Mountain Life and Work, January 1938, 5-6.
} 
Oakey Collins became successful businessmen with nothing more than the education they got at the Vardy School.

When the missionary workers arrived at the turn of the twentieth century, most of the population was illiterate. The people could not read or write. Even though some transactions were written down and recorded at the county seat, the persons involved were making Xs on these documents. Miss Rankin and later Mr. Leonard moved cautiously into this environment. They sensed that the assumptions of the literate outside world would not be acceptable to Vardy adults without sensitive mediation. Thus, Miss Rankin demonstrated health practices publicly and took medication herself before she tried to persuade those in the valley to co-operate with her recommendations. Leonard, too, was careful, writing in 1938, “A metropolitan Museum of Natural History very kindly provides our films. After careful experimentation, we are using silent films because they allow us to use the vocabulary that our children can understand and to connect up that which is being seen with previous knowledge and experience." ${ }^{10}$ This particular situation demonstrates that Leonard used deliberate methodology to build on what his students and the adults in the community were comfortable with as he moved them to higher levels of understanding and competence. People needed a foundation in plain words about familiar things before they could accept new words about unfamiliar things.

\footnotetext{
${ }^{10}$ Chester Leonard, "Vardy Community School," 5.
} 


\section{TREMORS AND RUMORS AMONG MOUNTAIN WORKERS}

Just as Vardy students were moving into the splendid new school building, others were voicing doubts. Some in the mountain settlement schools were not sure the movement was going in the right direction. The Vardy mission developed late, and because there was no influx of industry by way of mining or a big lumber operation into the valley, the work at Vardy took a different course from some of the less isolated enterprises. Some leaders in mountain work claimed that the mission schools were on their way out by the 1920s, yet the new school building at Vardy was not even started until 1926 and wasn't finished until 1929. A prominent voice for mountain workers was that of Olive Dame Campbell. Campbell had been married to John C. Campbell of the Russell Sage Foundation who had done the landmark survey of the Appalachian social and economic conditions in 1908-1909. After his death, she founded the John C. Campbell Folk School at Brasstown, North Carolina. She addressed a yearly conference of mountain workers in 1929 with this question:

Is there not something a little false in the position of an endowed school [sic] which has no real roots in the basic life of its section, which derives its standards, practices and support from other, usually very different sections? ... Have we any right to hold out material comforts, dress, education, standards, which it is impossible for neighbors to secure with the means at their disposal? Is it too much to ask that, if our standards are important, we not only live them, but attain them as far as possible by means through which our neighbors may hope to acquire them? Surely our teaching is false unless we can offer hope; unless we have faith in what the country may be, and work toward the only basis on which faith may 
be realized. I admit all the difficulties. They are legion. But otherwise, what is left but to frankly advise people to go where they can get those things which seem to us necessary ${ }^{11}$

Campbell saw the danger of inculcating a way of life in the people that was not sustainable should they choose to remain on the land. By 1929, mountain children and adults were leaving in droves to get work for cash money in the coal mines of the region and in factories beyond Appalachia's borders. The situation was delicate. As already noted, Leonard's very early admission in the 1928 article in the Presbyterian Advance that the Vardy Community Center could never be self-supporting insured its decline. The Presbyterian idea was to provide stepping-stones to independence; the missionaries and their agencies believed that the local officials in the public sector, noticing and appreciating the excellent work of the missionaries, would eventually take over. At Vardy and some other mission/settlement schools, the bar was too high. The public schools in Hancock County still do not meet the standard that the Vardy School set. Danny Turnmire, a Sneedville educator, wrote in his 1984 M.A. thesis, While Hancock County was struggling to maintain its schools on the meager tax dollars and state aid, the Melungeon community was enjoying educational opportunities not afforded by the remainder of the county. By 1930, Vardy had grown from the tiny one-room, double-doored building to a stately three-story, white frame structure, complete with modern kitchen facilities for serving hot lunches and teaching homemaking skills and industrial arts, a science laboratory,

\footnotetext{
${ }^{11}$ Olive Dame Campbell, “Are We Developing Dependence or Independence?” Mountain Life and Work, July 1929, 13.
} 
an extensive library, dormitories for teachers and students who needed boarding, and night school for adult education programs. ${ }^{12}$

Had Chester Leonard perhaps done his work too well? Was he fostering expectations that were unrealistic for the people of the Vardy community?

Olive Dame Campbell closed her 1929 talk by urging her compatriots to examine what they were doing and to try new strategies to meet the challenges in the mountains. She left her audience with this telling example: "All honor to one of our veteran mountain workers who recently said, I am told, that she now realized that she has done too much for her people, made them dependent. In these, her last, years of activity she has been trying to undo all she had tried to do before. ${ }^{\prime 13}$ Leonard, in declining health by the late 1940s, may have started the weaning process too late. He had facilitated the county's takeover of the school, but the rest of his elaborate program at the Vardy Presbyterian Center rested on him and his extended family. This was evident to at least one outside visitor, Edwin Kennedy, D.D., in 1947:

For the whole spirit of the place is Christian friendliness and understanding and the desire to help, which radiate from the Leonard's [sic] home as a glowing center... . [H]e told me that the attendance at the various activities and session of the center total 50,452 . . a record of which he, and we, may be rightly proud.

Four years ago by a special arrangement, the county took over the actual running of the school as far as the courses and teacher are concerned, but the school still meets at the Vardy Center where the children can have the benefit of

\footnotetext{
${ }^{12}$ Danny Turnmire, "Education of the Melungeons," 23.

${ }^{13}$ Olive Campbell, "Dependence or Independence?" 16.
} 
religious influence, vocational training, and excellent social and recreational advantages. ${ }^{14}$

Leonard believed fervently in the "advantages" he was providing for Vardy citizens through the community nights, adult education, visiting teachers, and the rest. It is tempting to say the people did not value these services, since they were not continued after Leonard left in 1951. But, that may be too harsh a judgment. Vardy residents may have wanted the services and not had the wherewithal to facilitate them without not only Leonard's leadership, but also his access to outside funds.

\section{RESPONSES TO GAINING LITERACY:}

\section{THREE GROUPS OF VARDY SCHOOL ALUMNI}

The people I have formally interviewed, as well as other Vardy alumni I have encountered, are quick to tell me that their Vardy years were the best of their lives. They admit no emotional conflict over what the Presbyterian Center unselfishly gave them. Theorist Deborah Brandt articulates what she calls a familiar cultural motif, "[a] workingclass scholarship student who goes off to school and becomes literate, is forever estranged from home, ruined, in a sense, by a new and irreconcilable way of being in the world." ${ }^{\prime 15}$ Even though many of those I have talked to left Vardy as young adults, they definitely do not agree with Brandt, for they do not see that anything they lost (homeplace or familiar culture) was valuable. One person told me that he never got as much as he wanted to eat except at the school hot lunch program; he was determined to find a

\footnotetext{
${ }^{14}$ Edwin Kennedy quoted in "Echoes From Vardy," Bill Grohse's weekly newspaper column, Citizen Tribune, 8 February 1981, D-4.

${ }^{15}$ Deborah Brandt, Literacy in American Lives, 1 .
} 
place to live where he wouldn't have to be hungry. Furthermore, these Vardy alumni don't feel estranged from their former lives no matter how their situations might look to outsiders.

The Vardy School and Community Center met the goals it set in the early years of the century. The remarkable success of the experiment rests on the powerful dreams and the considerable expertise of Rankin and Leonard as well as those other people they were able to gather around them as helpers. The Vardy students are very clear about what happened and why they valued their time at the school so much—it was the teachers, their love of teaching and learning, the high expectations they had, and their love and respect for the pupils under their care.

In my research process, I conducted formal extended interviews with four people. One of those had worked at the Vardy School as a cook; the other three were students in separate decades, the $30 \mathrm{~s}$, when the school was under the aegis of the Board of National Missions, the late 40s-early 50s, right after the take-over by Hancock County; and the $60 \mathrm{~s}$, when consolidation was imminent. In addition to these formal interviews, I have met many more Vardy alumni at several school reunions and gatherings. While all of these people are grateful for the education and nuture they received at the school and the community center, different ones took different paths. I can identify three distinct groups.

The first group is those who left Vardy to make their lives in the outside world. One person said that the education he got at Vardy made him realize there was more to life than subsistence farming or sharecropping. He wanted a house with modern conveniences. Even though persons in this group consider Vardy home, they wanted what money could buy. There were enclaves of Vardy folk in the Baltimore area, in Indiana, 
and in Illinois. One person or family would leave, and word would come back that jobs were plentiful. Others would soon follow.

Ruth Muhlbauer is one of these Vardy School graduates. She went on to high school at Dorland-Bell in North Carolina, continued her education at Knoxville Business College, and then joined the Navy during World War II. She said during an interview for the oral history project,

When I got out [of the Navy], there wasn't anything for me to do down home because there's nothing to do there, not even today. People had to go to Morristown or other places to get jobs. There wasn't anything available for me to do so I took my civil service exam and started working for the federal government.

So if people wanted to make money during the war, they would come up here to Baltimore because the jobs were so plentiful. They worked at Bethlehem Steel Company, which was in shipbuilding, and with an airplane manufacturing business. They came up here by the truckloads. ${ }^{16}$

These emigrants were and are still very tied to the hills. They continue to visit often and usually plan to be buried in one of the Vardy cemeteries when they die. Seven Gibson, original Melungeon settler Shepherd Gibson's descendant and the current pastor of Elm Springs Baptist Church just about four miles from the Vardy Church Museum, holds a tent revival in the Baltimore area every summer to connect with the very real community of Vardy émigrés (born in Maryland but still "from Vardy"). "I got tired of

\footnotetext{
${ }^{16}$ Ruth Muhlbauer, Oral History Interview, quoted in Windows on the Past, 85.
} 
burying people I didn't know," he said. Several from Maryland (pronounced "murr-uhlind" by all) are active in the Historical Society and its projects.

The second group is those who left Vardy to get further education and then came back to Hancock County to serve as educators and as nurses. One of my informants, who had Miss Avery, Reverend Arnold Johnson, and Elmer Turner in his school days at Vardy well after the end of the Chester Leonard era, described how miserable and homesick he was at college first at University of Tennessee in Knoxville and later at East Tennessee State in Johnson City. Like many first-generation Appalachian college students even today, he went home every weekend. He credits his teacher and mentor Elmer Turner with his ultimate success,

He created me; I'm lucky to have had Mr. Turner. He had the ability to challenge me and to make me challenge everything. He stressed reading, math, and language skills—especially correct grammar. Mr. Turner, and Claude Collins [a Vardy graduate who taught English], and Helen Mullins [the first Vardy alum to graduate from college at Maryville], who taught biology at the high school [in Sneedville] —all had a great philosophy and great techniques. The nurtured the seed planted at Vardy. They were caring teachers who stressed moral issues, educational issues, and taught life skills. They would say to us, "These are things you're going to need to do well in life."

A second example of this group is Claude Collins, mentioned above, who was a star student at Vardy in the late 1930s and graduated from high school in Sneedville in 1947. He went on to college and served as a teacher and administrator in the Hancock County School System his entire professional life. As I have looked through stacks of 
newspaper clippings, I can't help but notice how influential Collins has been. He was a leader on the committee that worked to make the Melungeon drama, Walk Toward the Sunset, go from dream to reality. Now the treasurer of the Vardy Community Historical Society, he is still active in its many projects and is dedicated to preserving his Melungeon heritage. He has wonderful stories to tell about his childhood on Newman's Ridge, the Leonards, Miss Rankin, and his long tenure in the Hancock County Schools. He is also a part of the Melungeon Heritage Association that unites efforts in Hancock County with those in Wise County, Virginia. Service is the hallmark of Claude Collins' life.

The third group is comprised of those who stayed behind. Some, who never left Hancock County, did not even complete high school. People I am acquainted with in this group have been involved in some small farming operations like raising a few beef cattle or growing tobacco, have worked in the few manufacturing plants within driving distance, and have worked as hired help for those who own land. Some combine all these jobs. One was a long-distance truck driver. Others are subsisting on the bounty of government entitlement. Men in this group have a history of struggling with the temptations of alcohol and recently with abuse of prescription drugs.

In the spring of 2003, when I was in Vardy doing interviews, the cabin where I stayed was across the valley from a trailer. The family that lives there, descendants of Vardy's earliest settlers, is "on the draw"; no one works. Their two vehicles rarely leave the yard. There is a mowed grass around the trailer that is equipped with a satellite dish but no garden plot. Vardy families used to subsist actively by growing their food and raising animals for meat. Now they subsist passively expecting cash and food stamps 
from the federal government, and they rely on Tenncare to meet their health needs. ${ }^{17}$ Did this pattern begin a century ago when the Presbyterians came?

One woman I met is a very different example of a person who stayed in Hancock County. She left Vardy School as the result of a disciplinary incident. Here's the story as she told it to me.

I went [to Vardy School] in '38 to '45. The reason I didn't go no longer, a dime knocked me out of it....

I wouldn't pay the ten cents so I went to Sneedville school. I went to Vardy—see, Darnell Williams drove a pickup truck with a cattle rack with a tar paper over it and seats around in the bed.... I don't remember why we got mad, but we fight in the bus or truck—we call it bus, it was a truck—every Thursday night. I don't know why, we fight like cats and dogs, and we was going to have to walk home the next day....

We got mad at Darnell, we call him bus driver, truck driver, and we tore the paper - the tar paper - off this truck, which he put up there to protect us, you know. And he went an' told on us the next morning, and Mr. Leonard went and

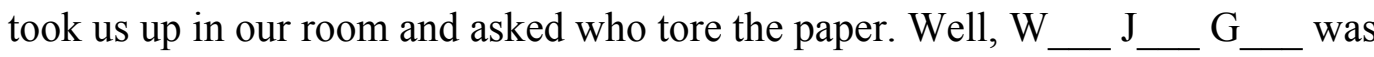
my cousin and he stayed with us. ... he stuck up his hand and he says, "Mr. Leonard, I didn't have no choice. They tell me I have to eat a piece or tear a piece," and he says, "I done tear a piece." And he reached up and tore his piece and that made us all tear one, too.

\footnotetext{
${ }^{17}$ As of January 2005, Tenncare has been radically cut back; this family may well be dropped from the Tenncare rolls.
} 
[Mr. Leonard] told all of us_-give us a good talking to, which wasn't right—and told us before we come back to school again we'd have to give a dime before we could go back, ride the truck or bus again.

So I wouldn't give my dime. I was guilty, but I wouldn't give my dime, so I went to Sneedville Elementary School. ... But the most education that I got was at Vardy.

This person's memories of her time at Vardy sparkle with detail and her pride at having participated in the grand enterprise. She does not resent the fact that Chester Leonard, sponsor of literacy, in a sense prohibited her from finishing out her elementary school education at Vardy. When I asked her how she has used what education she got before she dropped out of high school to get married, she ushered me into a special room in her house that has floor-to-ceiling bookcases on two walls. The shelves are lined with notebooks that are fat with genealogical papers, newspaper clippings and letters. At the time I interviewed her, she had already published one book about her husband's family and has since published another about her family. She can trace her ancestry back to Shepherd Gibson, one of the very first Vardy residents. This woman does not type and does not own a computer. She writes in long hand and pays others to type for her. She communicates by phone and fax with a vast constituency of researchers who appreciate her detailed knowledge of Hancock County's Melungeon families. Her genealogical center does include a photocopier. She told me, "I always wanted to be a teacher or a nurse.... My dream's come true. I've got childrens is teachers and grandchildrens a nurse. I'm hoping for a lawyer." 
Between the lines in these narratives are the truths that Shirley Brice Heath revealed in her article "What No Bedtime Story Means: Narrative Skills at Home and School," and in her subsequent book Ways with Words. Heath talks about social class and its implications for children's behaviors and performance in school. Her observations about how the expectations placed on children in their upbringing carry over into education settings are valid and applicable to what happened at Vardy. Some children like Dan and Adelaide Horton's four daughters and Drew and Alyce Williams's children came up in homes where education was a priority. The assumption was that formal schooling did not end with high school. These children met those expectations, went to college, and joined the ranks of professionals in education, business, and the law. This is not surprising. These families owned land, which gave them considerable status in the community as well as income from selling farm produce and timber.

A second cohort of people is, however, more remarkable. These students were raised in homes where eking out a living by share-cropping and gardening, gaining some cash by logging, stone cutting, or distilling was more important than perfect attendance at school. Some of my informants told me about having to miss school to attend to planting, or hoeing, or harvesting, or hog-killing; for their parents there was no question about which was top priority. In every case, though, the people in this second group formed a strong attachment to a beloved teacher, a powerful sponsor of literacy-Mary Rankin, Chester Leonard, Elmer Turner. The values and expectations of the adopted role model took precedence over parental patterns of life and work. These students adopted the literacy practices and attitudes of the school world. In addition, they all mentioned that 
their mothers had dreamed futures for them that extended beyond the narrow valley where they had been born.

\section{INFLUENCES FROM OUTSIDE}

In addition to identifying these three clearly delineated groups of Vardy School alumni, I have noticed another persistent phenomenon. It is the entrance of ideas that were prevalent in the world beyond the barriers of Newman's Ridge and Powell Mountain. Not only did some Vardy residents leave the confines of the valley. Certain people, who were not missionaries (and therefore, just residents for a season of service) came into the community and stayed. They came with their friends who were Vardy born and bred. Several of these outsiders became key players in both the valley's society and its economy.

Military service has been one way that Vardy's finest young men and women have always participated in the mainstream of American life. Batey Collins is an example of a person who absorbed some "new" ideas as he served in the Civil War. My guess is that he was impressed by the cities he visited in the course of his enlistment. He may have decided that education was a key factor in the differences between life in the isolated valley where he grew up and what he saw during his travels. Once back in Vardy, he became a leader in that community and the person that the Presbyterians knew — knew well enough to make a two-day journey over bad roads to investigate the possibility of starting a school and community center. Batey Collins realized that school attendance for Vardy residents in Sneedville was impossible for at least two reasons: the inhospitable attitudes of the white citizens and the sheer physical impossibility of getting 
over the ridge. Collins realized that if there was going to be a school in the Vardy community, he had to figure out a way. I suspect that he had either heard about Presbyterian missions in other places or had seen one first-hand. He turned to the Presbyterians for assistance.

Two other outsiders came to Vardy as friends of Vardy residents they had served with in the armed forces. Daniel Boone Horton, who married Batey's daughter Adelaide, came to Vardy after the Spanish American War with his buddy Wiley Gibson. Horton was a shrewd businessman who took over the operation of his father-in-law's boarding house, ran a store and a mill, and continued to buy more and more land. Several of his half brothers and sisters also came to Vardy and stayed, marrying into various families. Horton, knowing the value of education, moved his family of four daughters to Ewing, Virginia, so the girls could attend the high school there; some nephews and nieces also boarded with Dan and Adelaide in Ewing so they could go to school, too. During the 1920s, Horton sent all four of his daughters to college — not usual for Vardy stock. Horton was a stand-out in Vardy history.

A second outsider was William Grohse, who came to Vardy after World War I with his buddy Oppie Miser. Bill married Lillian Miser, sister to Oppie, daughter of Nancy Collins Miser, grand-daughter of Batey and Cynthia Collins. Bill farmed some and operated the general store in Vardy; by the end of his life, he became the undisputed community historian and genealogical expert. For years he wrote a column called "Echoes From Vardy" that appeared in several area newspapers. The "Bill Grohse material" is important for any researcher who would understand the history of the Vardy Community. Grohse moved his parents, who had been born in Germany, to the valley. He 
remodeled the 1902 schoolhouse to be his home, and in 1933 joined the Presbyterian Church where he served as Elder and Clerk of Session. He along, with Drew Williams, struggled to keep the Presbyterian Church going for many years.

Another very significant outsider was Drew B. Williams. Marrying Alyce Horton after graduating from Berea College, Williams began teaching with Mr. Leonard and Miss Rankin. He quickly showed leadership potential and worked hand-in-hand with Leonard to establish and guarantee the excellence of the Vardy School. Williams joined the Vardy Presbyterian Church the same day as Bill Grohse. When Leonard retired in 1951, Williams was Moderator Pro-tem of the Church. Because both he and his wife Alyce were educators, they paid people to work the farmland she had inherited from her father, and they continued to buy more property in the valley. His children still hold deeds to the "Williams Farm" and manage that agricultural enterprise.

These outsiders brought up-to-date ideas, high energy, and new genes to the Melungeons.

\section{WAS ANYBODY LISTENING?}

If a decaying weather-battered school building collapses on a mountainside and no one is there to hear the breaking glass and splintering timbers, does it make a noise?

The Vardy Experiment is now truly history. On October 14, 2003, even the hope that the extravagant building might some day be restored as a museum or a monument to its founder died. The neglected building blew down, imploded, on a day of fierce wind. Some would label the Vardy experiment an unqualified success. Others, like scholar David Whisnant, who has sharply criticized the mountain undertakings by outsiders, 
would be more cautious. "[Church schools] suffered from 'long distance control' by

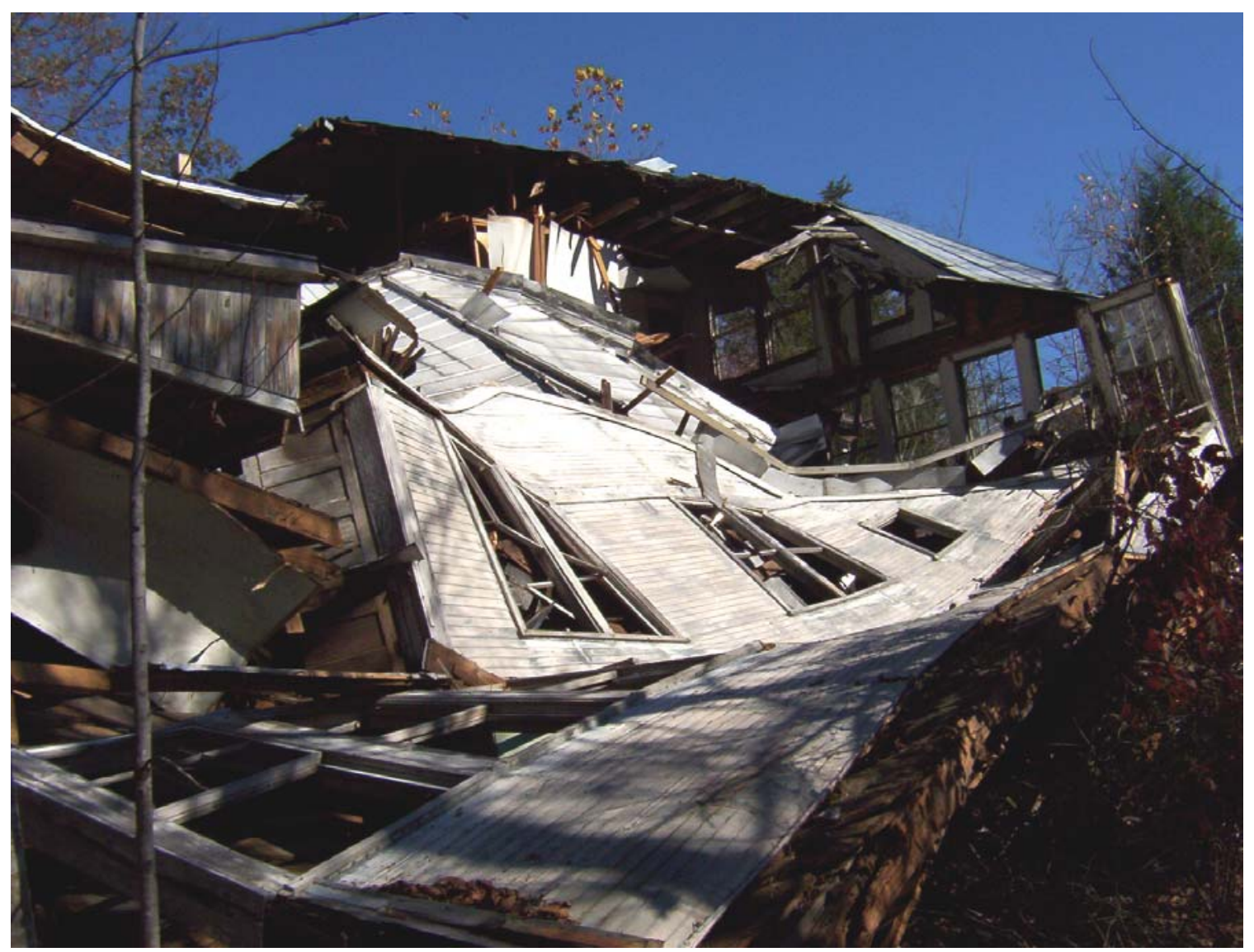

This photograph was taken in late October 2003.

church boards, and [independent settlement schools] were too dependent on their individual founders," he wrote. ${ }^{18}$ Does this indictment apply to Vardy? Perhaps in some part, despite the fact that Leonard, not the Board in New York, had control within the parameters of the Presbyterian vision for its Appalachian programs, Leonard's prominence in the Vardy mission created a problem. The very vision that inspired his work mandated dependence on him. The Vardy Center did not survive Leonard's

\footnotetext{
${ }^{18}$ David Whisnant, All That Is Native and Fine, 130.
} 
departure; ever after there was an unsuccessful effort to live up to what he had made, been, and accomplished.

Whisnant, at the end of his book, does acknowledge the complexity of what transpired not just at Vardy, but in many mountain communities where "settlement" schools flourished.

More important than buildings are the shadows of people, programs and ideas which still stretch across the intellectual and cultural landscape in the mountains. . .. Thus to note that many cultural intervention efforts "fail" - that the intervenors do not persevere individually, or that some of their institutions do not last-is too facile. Even when institutions pass from the scene, attitudes and assumptions remain, styles and designs persist, myths retain credibility.

Cultural intervention is, finally, a process which must be comprehended not only as an important element of the cultural history of one region in one period, but as a little understood feature of every cultural past, an inevitable component of every cultural present and future. ${ }^{19}$

The shadows of Mary Rankin and Chester Leonard and even the wreck of the magnificent building still live in Hancock County. In fact, these two missionaries and their work are not only known but also revered wherever Melungeon descendants talk of their history. It's not even possible to imagine what might have been without them. They came and changed not only the landscape but also the people irrevocably.

\footnotetext{
${ }^{19}$ David Whisnant, All That Is Native and Fine, 254.
} 
To me, an educator by choice, by training, and by heritage ${ }^{20}$ the enterprise at Vardy is both an encouragement and a warning. It tells me that education can make a tremendous difference in people's lives. It can give them the literacy of reading and writing, improve their health, broaden their awareness, and equip them to be contributors to the life of the body politic, and teach them to embrace their legal rights in society. There is a possibility that I as a teacher might become a significant role model for one student or lead another to realize her academic potential. Just such a student might even adopt my bookish ways and chose to read bedtime stories to her children.

However, education is not a cookie cutter that will make everyone turn out middle class. It cannot assure that a school graduate will make wholesome life choices about nutrition, addictive substances, sexual partners, or recreation. It cannot automatically instill a respect for hard work if the pupil is fixed on finding a way to qualify for SSI. It cannot enforce a particular aesthetic (all things that are "native and fine"); some who are successful in school may still opt to decorate their living rooms with air-brushed paintings on black velvet instead of an old pieced quilt, a mountain dulcimer, or a handwoven coverlet. The variety of roles and life-styles that Vardy Community School alumni pursue underscores these truths, if I hadn't learned them already.

Furthermore, this experiment at Vardy, magnificent as it was in many ways, did not neutralize the stigma of being Melungeon for its students. Intuitive consciousness of "difference" persists among Melungeon descendants. Instead of enjoying their legislated and guaranteed equality on the streets of Sneedville, Tennessee, or Wise, Virginia, self-

\footnotetext{
${ }^{20}$ My grandmother was a grammar school principal, my father an English teacher and long time yearbook advisor, my stepfather a history teacher and guidance counselor, my mom a teacher and high school principal, and my aunt an elementary teacher.
} 
acknowledged Melungeons are exploring the rhetoric and politics of difference on the Internet where twenty-first century literacy practices of website building and email list discussion help them explore their social position outside the mainstream. 


\section{Chapter 6}

\section{A World Depicted and Displayed: Melungeon Websites}

\section{CHAPTER INTRODUCTION}

So far in this dissertation, I have used the term literacy in two ways. Initially I described a literacy of Melungeon-ness by defining what the word Melungeon means, outlining possible etymologies, and detailing the experiences that Melungeon descendants share. Second, I used literacy to mean reading and writing, two skills that could not be taken for granted a century ago in the rural Appalachian communities where Melungeon descendants lived and worked the land. Reading and writing came to the Hancock County, Tennessee, Melungeons through the remarkable settlement school in the Vardy Valley where literacy was ably sponsored and carefully built by the two extraordinary Presbyterian missionaries, Mary Rankin and Chester Leonard. These two practiced literacy in plain view of both children and adults and invited their participation. Today, Melungeons are reading and writing in many ways.

In addition to dealing with government bureaucracy, reading newspapers, writing letters, processing advertisements, creating business cards, and exchanging recipes and instructions for many tasks, Melungeon descendants I have met are researching their family genealogies, writing grant applications, and authoring articles and books. In addition they are creating websites and communicating by email. Their literacy practices resemble those of many people around the world and reflect a significant change in 
communication methods. Many of them are relying on screens as well as pages for both formal and informal communication with friends, relatives, and people they have never met.

This chapter will look carefully at the literacy practices of three website designers by describing and analyzing their work from both semiotic and rhetorical perspectives.

\section{A THEORETICAL SEMIOTIC FRAMEWORK:}

\section{SCREENS NOT PAGES, THE DOMINANT MODE}

In 1998, Mitchell Stephens published The Rise of the Image, the Fall of the Word, in which he argued that books were on the way out and moving images had replaced them. ${ }^{1}$ In 2003, Gunther Kress, professor of English at the University of London, authored Literacy in the New Media Age; he agrees with Stephens that books are no longer the dominant medium of communication. Kress allows that images, still or moving, are replacing writing as the primary communicative mode, and that screens have edged out books, which held sway for nearly 2000 years. Kress's one disclaimer is that writing will remain the preferred mode of the political and cultural elites. However, for most people, writes Kress, "language-as-writing will increasingly be displaced by image in many domains of public communication., ${ }^{2}$ Furthermore, this significant change in communication will have profound effects on literacy, culture, knowledge, and power

\footnotetext{
${ }^{1}$ Mitchell Stephens, The Rise of the Image, the Fall of the Word (New York: Oxford University Press, 1998).

${ }^{2}$ Gunther Kress, Literacy in the New Media Age, (London: Routledge, 2003), 1.
} 
dynamics. ${ }^{3}$ Kress's theory illuminates the processes of both the creation and reading of screens (websites).

In his 2003 book, Kress raises two questions: What is the future of literacy? And, what are the social and cultural effects of the emergence of the screen as the dominant medium? Kress defines literacy as "the term to use when we make messages using letters as the means for recording the message. ${ }^{4} \mathrm{He}$ does not favor adding adjectives to this term to expand its meaning; for example he would not advocate using "visual literacy" to refer to making or understanding messages that use images to communicate. He admits that computers, which he calls "the new technologies of information and communication, ${ }^{, 5}$ do make the situation very complex because they situate resources for representation, production, and dissemination of texts in the same location, in fact in the same machine. Nevertheless, he maintains that the processes and skills needed to enact the different modes are separate: to use writing is to employ letters to make words that convey meaning, to use images is to choose and display images according to a plan. $\mathrm{He}$ writes, "these are distinct resources and require distinct competencies in their use and their design, no matter whether on the page or on the screen."

Kress like Stephens has great affection for books, but he does not make value judgments about the fact that writing is no longer emphasized in public communication. Instead he proposes a new paradigm for thinking about making and receiving meaning. Although there will be much analysis of writing (literacy enacted) in this chapter because Melungeon websites are largely repositories of documents, a reader must find these texts.

\footnotetext{
${ }^{3}$ Gunther Kress, Literacy, 1.

${ }^{4}$ Gunther Kress, Literacy, 23.

${ }^{5}$ Gunther Kress, Literacy, 23.

${ }^{6}$ Gunther Kress, Literacy, 23-24.
} 
That process happens on screen. Therefore, it is necessary to discuss websites not as book pages but as screens, and it is necessary to have a way to understand and deconstruct websites as they appear on a personal computer connected to the Internet. Kress's book offers such a scheme.

According to Kress, communication is language-based. Speech will continue to be the major mode of communication. However, writing will not be the automatic second; screens are already dominating, and image-laden displays are influencing print media such as newspapers and textbooks. The changes are more than simply visual; they are epistemic. Speech and writing are narrative. Events in speech and words proceed one after another organized by the logic of time. However, "displays," which is how one would label screens, are organized by the logic of space. There are some conventions that govern the use of space in the traditions of Western art and graphic design; however, the creator of a display can override the conventions by emphasizing one element using color, shape, placement, or content. Furthermore, the reader of a display can choose to disregard its creator's hints about reading, and choose her own point of entry. The different modes (writing/speaking versus images), says Kress, have different affordances; they accomplish different things in different ways. As he maintains, “The world narrated' is a different world than 'the world depicted and displayed."”7

Literacy practices are changing as the screen emerges as the primary communicative medium. Writing is still important, but it is subservient to display. The screen is a visual entity, and the graphic marks that appear on it, even if those marks are

\footnotetext{
${ }^{7}$ Gunther Kress, Literacy, 2.
} 
letters, are organized visually; the text has to "look good." accompanied more and more by images, and placement of text and images has consequences for viewers in that placement affects the meaning. ${ }^{9}$

\section{NEW MEDIA’S EFFECTS ON COMMUNICATION}

New media and its possibilities are having some potent effects on communication. ${ }^{10}$ First, it is easy to use a multiplicity of modes to convey meaning — text, still images, sound effects, moving images, and music are all rendered in the same way - through digital code. Second, there is a possibility for interactivity in two ways: the viewer can write back to the producer of a text, and the user can hypertextually enter into a new relationship with other texts by clicking the mouse. Third, the power to produce messages is available to all; there is no gate-keeping. ${ }^{11}$ As Kress points out, when everyone is an author, authority wanes or disappears. ${ }^{12}$ In addition, he notes a fourth effect, the move away from formal language toward more speech-like forms that is prevalent on websites. $^{13}$

A fifth effect is the possibility for variation in the reading path. In writing, the reading path is rigidly set by the writer. The reader uses imagination to fill the words with meaning. However, in image, the elements are already "meaning-full." The reader of the image is encouraged to follow a particular path but not compelled. The reader of the

\footnotetext{
${ }^{8}$ Gunther Kress, Literacy, 65.

${ }^{9}$ Gunther Kress, Literacy, 65.

${ }^{10}$ Gunther Kress, Literacy, 5.

${ }^{11}$ Gunther Kress, Literacy, 17.

${ }^{12}$ Gunther Kress, Literacy, 172.

${ }^{13}$ Gunther Kress, Literacy, 12.
} 
image or the website is presented with a display; she can choose what to look at or where to click.

Lev Manovich is another theorist who addresses this characteristic - the possibility to choose a reading path, which is the quintessence of a new media text. ${ }^{14} \mathrm{He}$ explains that all websites are databases, a form that has not been privileged in our culture of written communication, as has the narrative tradition. For example, he says that a sentence is made up of a particular group of words strung together one after another, a syntagm (this idea is another way to state Kress's notion of the logic of time that inheres in speech and writing). All the possible words that exist, the paradigmatic sets to which the sentence's words belong, are in the background in the writer's and the readers' minds. However, new media texts reverse this relationship. Databases (the paradigms of possibilities) are foregrounded and narratives (the syntagms) are waiting to be constructed by individuals who visit the sites. Many sites have a menu of available choices visible on the screen; each choice is merely a mouse click away. The website is like an instant version of a dictionary or encyclopedia, neither of which are read cover-tocover. Each reader makes her own step-by-step reading path.

\section{A SOCIAL SEMIOTIC}

In order to have a cogent method for understanding and analyzing new media, Kress proposes what he calls "a social semiotic" that both producers and readers of texts can use for communication. He borrows the terminology of the sign from both Charles Sanders Peirce and Ferdinand de Saussure. Kress departs from Saussure's semiotic by

\footnotetext{
${ }^{14}$ Lev Manovich, The Language of New Media, (Cambridge, MA: MIT Press, 2001), 230.
} 
saying that communication is more than a linguistic phenomenon: "Language alone cannot give us access to the meaning of the multimodally constituted message; language and literacy now have to be seen as partial bearers of meaning only." ${ }^{15}$ Simply stated by Kress, semiotics is sign-making, the fusion of form (signifier) and meaning (signified). ${ }^{16}$ The meaning can be spread across several modes. A sign is articulated, or outwardly constituted, by the producer of a message. When another person receives that message, he or she interprets, or inwardly constitutes, the sign. ${ }^{17}$ The form and the meaning of a sign cannot be separated. Creativity is part of both the processes of articulation and interpretation. Furthermore, according to Kress, signs are always apt for the meaning signified and always represent the maker's interests, whether that sign-maker is articulating or interpreting the sign. ${ }^{18}$

In Kress's semiotic, the choice of mode becomes very important, more important even than choosing words to write or images to display, because there are so many modes available to choose from. The producer of a website is more than just a writer; she is a designer of new media objects who makes decisions about which mode best articulates the meaning she hopes to convey. In order to be effective, the sign must be appropriate for its social situation—so many choices, such high stakes.

The "stuff" of communication is fixed in each particular mode, but the shape of a text is determined by what Kress terms the genre, which he claims is the expression of the social relations of the participants in the social milieu where the text takes shape. In addition, there is the matter of what is at issue; Kress calls what is at issue discourse after

\footnotetext{
${ }^{15}$ Gunther Kress, Literacy, 35.

${ }^{16}$ Gunther Kress, Literacy, 41.

${ }^{17}$ Gunther Kress, Literacy, 44.

${ }^{18}$ Gunther Kress, Literacy, 45.
} 
the work of Michel Foucault. The item produced is a text; Kress insists that text is the appropriate term for any instantiation of communication in any mode.$^{19}$ Furthermore, every text has a site of appearance. For my purposes in this chapter, the texts I will be describing and analyzing will be Melungeon websites on the Internet. Kress reminds his readers that meaning-making in any mode always happens in a particular social domain and that the domain shapes the resources: "The social configuration of a group and its concerns, the social meanings and values of that group have their effects on the habitual uses of the resource and, in this way, in the longer-term shaping of the resource of that domain. ${ }^{20}$

This last sentence invites me to comment briefly on Melungeon sites. The Melungeons themselves, their attempts to define their identity, their shared history, and their points of disagreement (like who can be included and what counts as evidence)—all these things must be considered if a viewer would understand the websites they create. The values they hold, particularly their loyalty to their Appalachian roots and their disdain for systematic authority, make the Internet with its wide-open publication opportunities and possibilities for changing/updating information very attractive. Their suspicion of academics and academic discourse causes them to employ vernacular language to tell their stories and make their claims, one of the practices that Kress notes in his description/definition of the new communication on the Internet.

The Melungeons have taken to the Internet; they feel comfortable there. Melungeon designers are creatively articulating both old and new meanings in carefully nuanced ways on their websites; they have mastered enough of the technology to

\footnotetext{
${ }^{19}$ Gunther Kress, Literacy, 48.

${ }^{20}$ Gunther Kress, Literacy, 65.
} 
articulate signs that please them. As Kress explains, a site starts from the interest and intent of a specific designer who represents an ideological position; he/she has a set of available representational resources, a task to perform, and a specific audience in mind. ${ }^{21}$ With those things in place, the designer/web-master shapes a message. The messagemaker's action does not guarantee the reading he or she has intended, but no matter. Feedback on a website and its claims can be immediate, and changes are easy to make.

\section{A THEORETICAL RHETORICAL FRAMEWORK}

Gunther Kress's semiotic is a useful schema for understanding and analyzing new media objects as well as for constructing them. In the conclusion of Literacy in the New Media Age, Kress acknowledges the underlying connection between his semiotic approach and traditional rhetoric by referring to the important relationship between the sign-maker and her audience. In the creative process that results in a text, the designer must consider the audience when making choices of modes. Writes Kress, "modes of representation are used in relation to a multiplicity of factors, such as the sign-maker's sense of what are the apt modes for representing, given a certain audience and therefore specific relations between sign-maker and audience. Out of this awareness of the always rhetorical task of communication arises the arrangement of modes which are in play in a message/text. ${ }^{22}$

Communication that involves language, which Kress allows is the most dominant way to make and receive messages, stands on rhetoric. Therefore, understanding rhetorical principles is useful for both producers and receivers of texts. The semiotic terminology is an overlay upon ancient classical principles that stem from the Greek and

\footnotetext{
${ }^{21}$ Gunther Kress, Literacy, 169.

${ }^{22}$ Gunther Kress, Literacy, 169.
} 
Roman rhetoricians. Aristotle defined rhetoric as the power of finding the available arguments for a particular situation that will persuade the audience. In the ancient world rhetoric was thought to be essential for citizenship and could be used to make decisions, resolve disputes, mediate public discussion, and choose courses of action. It originates in disagreement; the ancient teachers and students of rhetoric would have scoffed at the modern equation between disagreement and rudeness, for they expected people to have different opinions about both mundane and important issues. In fact, as modern rhetoricians Sharon Crowley and Debra Hawhee point out, rhetoric gives those who disagree the opportunity and possibility to make important decisions without resorting to violence. $^{23}$

The Melungeons should be embracing the principles of rhetoric, for, even without acknowledging it, they are in a period of significant rhetorical debate. Although their mountain culture has a history of the violent resolution of differences, most of their battles now are skirmishes with words. The Internet is a suitable place for their discussion to occur because of the plasticity of the publishing mechanism, free distribution of information, and the easy inclusion of the diaspora — those of Melungeon descent who no longer live in Appalachia.

Productive rhetorical argument requires that all parties to an argument listen to positions stated by others. The websites and the email discussion lists allow this process to flourish privately. A person can pretend in her online persona not to be aware of opposing points of view, but in fact can read others' statements at leisure and compose her own considered responses.

\footnotetext{
${ }^{23}$ Sharon Crowley and Debra Hawhee, Ancient Rhetorics for Contemporary Students, ${ }^{\text {rd }}$ ed. (New York: Pearson Longman, 2004), 2.
} 


\section{THE CANON OF INVENTION}

Rhetoric terms the process of examining positions invention, which is the means of discovering available arguments; all parties should be willing to be persuaded by good arguments. The aim of classical rhetoric was to distribute the power that resides in language to all equally; social position was not as important as solid arguments. Modern rhetoric relies on facts, probably because of the faith in science and empirical proofs. However, ancient rhetoric preferred arguments, opinions, and carefully crafted language; rhetors believed that opinions were not threatening, for opinions could be changed. Strategies of invention will be the focus in my discussion of rhetoric as a methodology for creating and analyzing Melungeon websites.

As Kress notes in his book, the rhetorical situation is of primary importance.

Communication will not occur, or will occur other than as the rhetor/sign-maker intends, if the situation is not apprehended and heeded. The rhetorical situation has the following components:

- The issue

- The audience (and its relationship to the issue)

- The rhetor (and her relationship to the issue)

- The rhetor's reputation

- The time

- The place.

One approach to invention is kairos, defined by Crowley and Hawhee as "a notion of space and time, . . . a situational kind of time, . . . an advantageous time. ${ }^{.24}$ To use

\footnotetext{
${ }^{24}$ Sharon Crowley and Debra Hawhee, Ancient Rhetorics, 37.
} 
kairos advantageously is to take advantage of a propitious time and to be fully aware of the context of ideas, arguments, and persons. Melungeon websites are kairotic as they deal with the most current issues in genealogy, history, anthropology, and medicine that matter to their readers. One site posts a monthly feature article on a topic of current interest and also links to a blog that lists articles published in the popular press that relate to Melungeon issues; another has a newsy splash page that lists important happenings and upcoming events. However, the most decidedly kairotic stance occurs on the email discussion lists, where the majority of list messages pertain to timely topics. Rhetoricians see kairos as an opportunity to explore issues; however, Melungeon speakers and writers are not always interested in hearing or understanding an opposing point of view as my analysis will show.

A second approach to invention is stasis. Stasis theory consists of "a set of questions that, when asked systematically, can help [rhetors/designers] to determine just where it is that the disagreement between themselves and their audience begins. ${ }^{, 25}$ Melungeon writers on the web and speakers at the Unions could really profit from employing stasis theory; they could quite easily discover what they all affirm and then agree to disagree on some of the finer points. Taking the time to find all the available arguments, which is what the stasis questions help a rhetor/designer do, can assure her that an argument is defensible and that she has discovered the best evidence to support it. ${ }^{26}$ Asking and answering the stasis questions clarify thinking, reveal assumptions and values of the audience, show areas that need more research, suggest which proofs are

\footnotetext{
${ }^{25}$ Sharon Crowley and Debra Hawhee, Ancient Rhetorics, 53.

${ }^{26}$ Sharon Crowley and Debra Hawhee, Ancient Rhetorics, 54.
} 
most effective, and give ideas about effective arrangement. ${ }^{27}$ Listed below are four stases, or questions (and sub-categories of questions) to ask, which can be used to find the point(s) of disagreement:

- Conjecture: Does it exist? Did it happen?

- Definition: What kind of thing or event is it?

- Quality: Was it right or wrong?

- Policy: What should we do?

I would like to demonstrate this method of invention by testing a claim that is a common disputed point among Melungeon rhetors. There is little agreement on this issue, so examining it using the stasis questions reveals several other important contested issues and/or values. This claim is "We are Portyghee." See the questions designed in Crowley and Hawhee and my answers in Table 1 below.

Table 1

\begin{tabular}{|c|c|c|}
\hline Category & Question & Answer \\
\hline Conjecture & Does it exist? & Yes. \\
\hline Conjecture & $\begin{array}{l}\text { Where did it come from? How } \\
\text { did it begin? }\end{array}$ & $\begin{array}{l}\text { Oral tradition, passed down in } \\
\text { families, perpetuated in the popular } \\
\text { press }\end{array}$ \\
\hline Conjecture & What is its cause? & $\begin{array}{l}\text {-A true statement? } \\
\text {-The plight of the conversos after } \\
1492 \text { when the Spanish Inquisition } \\
\text { began. } \\
\text {-Desire not to be Negro (Chris } \\
\text { Everett). }\end{array}$ \\
\hline Conjecture & Can it be changed? & $\begin{array}{l}\text { Could possibly be proved or } \\
\text { disproved by exhaustive research, } \\
\text { but some might even then refuse to } \\
\text { change their opinion. }\end{array}$ \\
\hline Category & Question & Answer \\
\hline Definition & What kind of thing is it? & A claim. \\
\hline Definition & $\begin{array}{l}\text { To what larger class of things } \\
\text { does it belong? }\end{array}$ & $\begin{array}{l}\text { Assertions. Hopes. Facts ultimately } \\
\text { ratified by genealogical research. }\end{array}$ \\
\hline
\end{tabular}

\footnotetext{
${ }^{27}$ Sharon Crowley and Debra Hawhee, Ancient Rhetorics, 54.
} 


\begin{tabular}{|c|c|c|}
\hline Definition & $\begin{array}{l}\text { What are its parts? How are they } \\
\text { related? }\end{array}$ & $\begin{array}{l}\text { It is a claim that gives Melungeons a } \\
\text { certain identity. It explains their } \\
\text { origins and why they look different } \\
\text { from their whiter neighbors. It is a } \\
\text { tie to a romantic story of } \\
\text { shipwrecks, European exploration of } \\
\text { North America, and survival in spite } \\
\text { of extreme hardship. }\end{array}$ \\
\hline Category & Question & Answer \\
\hline Quality & Is it a good or a bad thing? & Depends on a person's ideology. \\
\hline Quality & $\begin{array}{l}\text { Should it be sought (embraced) } \\
\text { or avoided? }\end{array}$ & $\begin{array}{l}\text { Choice of the individual rhetor and } \\
\text { her assessment of the predisposition } \\
\text { of her audience. }\end{array}$ \\
\hline Quality & Is it right or wrong? & $\begin{array}{l}\text { This is not a moral question, so not } \\
\text { applicable. }\end{array}$ \\
\hline Quality & Is it honorable or dishonorable? & Depends on a person's ideology. \\
\hline Quality/Comparative & $\begin{array}{l}\text { Is it better or worse than } \\
\text { something else? }\end{array}$ & Depends on a person's ideology. \\
\hline Quality/Comparative & $\begin{array}{l}\text { Is it more desirable than any } \\
\text { alternatives? }\end{array}$ & Depends on a person's ideology. \\
\hline Quality/Comparative & $\begin{array}{l}\text { Is it less desirable than any } \\
\text { alternatives? }\end{array}$ & Depends on a person's ideology. \\
\hline Quality/Comparative & $\begin{array}{l}\text { Is it more or less right than } \\
\text { something else? }\end{array}$ & $\begin{array}{l}\text { Not a moral question, so not } \\
\text { applicable. }\end{array}$ \\
\hline Quality/Comparative & $\begin{array}{l}\text { Is it more or less honorable than } \\
\text { something else? }\end{array}$ & $\begin{array}{l}\text { Not a moral question, so not } \\
\text { applicable. }\end{array}$ \\
\hline Quality/Comparative & $\begin{array}{l}\text { Is it more or less base than } \\
\text { something else? }\end{array}$ & $\begin{array}{l}\text { Not a moral question, so not } \\
\text { applicable. }\end{array}$ \\
\hline Category & Question & Answer \\
\hline Policy/Deliberative & Should some action be taken? & Yes, more research. \\
\hline Policy/Deliberative & $\begin{array}{l}\text { Given the rhetorical situation, } \\
\text { what actions are possible? } \\
\text { Desirable? }\end{array}$ & $\begin{array}{l}\text { Historical research to locate } \\
\text { significant documents; more DNA } \\
\text { testing to ratify possibilities. }\end{array}$ \\
\hline Policy/Deliberative & $\begin{array}{l}\text { How will proposed actions } \\
\text { change the current state of } \\
\text { affairs? Or should the current } \\
\text { state remain unchanged? }\end{array}$ & $\begin{array}{l}\text { Ideology or network of } \\
\text { interpretation will determine who } \\
\text { believes what related to research. } \\
\text { Some will only accept written } \\
\text { documents; others are open to other } \\
\text { possibilities. }\end{array}$ \\
\hline Policy/Deliberative & $\begin{array}{l}\text { How will the proposed changes } \\
\text { make things better? Worse? In } \\
\text { what ways? For whom? }\end{array}$ & $\begin{array}{l}\text { More research will give Melungeon } \\
\text { descendants more information about } \\
\text { origin possibilities. One would } \\
\text { assume that more information is } \\
\text { good. }\end{array}$ \\
\hline Policy/Forensic & $\begin{array}{l}\text { Should some state of affairs be } \\
\text { regulated (or not) by some } \\
\text { formalized policy? }\end{array}$ & Question not applicable. \\
\hline Policy/Forensic & $\begin{array}{l}\text { Which policies can be } \\
\text { implemented? Which cannot? }\end{array}$ & $\begin{array}{l}\text { More documents and/or a persuasive } \\
\text { argument might change some } \\
\text { people's minds. }\end{array}$ \\
\hline
\end{tabular}




\begin{tabular}{|l|l|l|}
\hline Policy/Forensic & $\begin{array}{l}\text { What are the merits of } \\
\text { competing proposals? What are } \\
\text { their defects? }\end{array}$ & $\begin{array}{l}\text { Scholars and rhetors within the } \\
\text { Melungeon community have offered } \\
\text { informed opinions (Manuel Mira, } \\
\text { Eloy Gallegos, Elizabeth } \\
\text { Hirschman, Donald Panther-Yates). } \\
\text { The theories create a rich mosaic. } \\
\text { Defects are that there is no definitive } \\
\text { paper trail; furthermore, there are } \\
\text { years when Melungeons did not } \\
\text { have literacy. }\end{array}$ \\
\hline Policy/Forensic & $\begin{array}{l}\text { Each person must decide what to } \\
\text { believe. This decision will be } \\
\text { influenced by what that person } \\
\text { counts as persuasive evidence. }\end{array}$ \\
\hline
\end{tabular}

Answering the questions is a long exercise, but it does show where the important points are in the argument about whether or not to believe this claim. The questions of conjecture, definition, and policy are all fruitful in this case.

\section{THE IMPORTANCE OF AUDIENCE}

The answers to the questions in the category of quality also reveal an important fact about rhetorical argument: that ideology of the audience is crucial. Crowley and Hawhee define ideology as follows: "An ideology is a coherent set of beliefs that people use to understand events and the behavior of other people; [ideologies] are also used to predict events and behaviors... [ [I]deologies help us to decide how to value what we knowthey tell us what is thought to be true, or right, or good, or beautiful. ${ }^{, 28}$ Information about the claim to Portuguese ancestry back in the sixteenth century, which probably cannot be definitively proved due to gaps in the written record, will be processed according to a person's network of interpretation. This is a way of saying that what a person values and believes determines which arguments will be persuasive. In the Melungeon community

\footnotetext{
${ }^{28}$ Sharon Crowley and Debra Hawhee, Ancient Rhetorics, 25.
} 
there is a lively debate about what counts as evidence. Some allow only "hard" evidence in the form of documents or found archaeological artifacts. Others admit elements of oral tradition, possibilities suggested by DNA testing, and extrapolation from known information or practices.

A recent book by Elizabeth Hirschman, Melungeons: The Last Lost Tribe, takes the evidence familiar to all Melungeon researchers and draws a new conclusion. ${ }^{29}$ Hirschman thinks that the Melungeon ancestry includes Muslims and Sephardic Jews, the conversos forced out of the Iberian Peninsula by the Spanish Inquisition who nominally converted to Christianity and instead of becoming Christians continued their religious practices in the privacy of their homes. Many of these displaced people ended up in North America. She cites naming patterns, marriage customs, burial practices (some grave markers in Appalachia have Stars of David on them), evidence of freemasonry, and membership in Old Regular Baptist congregations as pointers to her theory. She has done her scholarly homework looking at European documents, the history of freemasonry, and also personal genealogy. Hirschman has spoken at the Unions, published articles on one of the websites, and participated in email list discussion. Will the larger Melungeon community accept her thesis? Or rather, will their ideologies allow them even to consider her arguments? The jury is still out.

\section{THE COMMON TOPICS OF RHETORIC}

A third approach to invention is through the topics or the "common places" of rhetoric.

"Place" was meant literally as it originally referred to the area on a papyrus roll where a

\footnotetext{
${ }^{29}$ Elizabeth Hirschman, Melungeons: The Last Lost Tribe, (Macon, GA: Mercer University Press, 2005).
} 
particular topic was listed. Later, the term "commonplace" came to mean the intellectual source of a proof that could be inserted into any discourse. Aristotle devised a classification scheme, informed by what he considered to be the three common topics, that looks like this; 1) past/future fact; 2) greater/lesser; and 3) possible/impossible.

Past/future fact and possible/impossible are widely used in Melungeon rhetoric. Brent Kennedy's piece about how his Siddi-related DNA might have come to be is an example of past conjecture, a use of past/future fact. Crowley and Hawhee note that such rhetoric does not yield fact in the modern sense of the word, but instead outlines an educated guess about something that probably took place in the past. Libby Killebrew's reference to the Portuguese origin theory for the first Melungeons in North America is based on the common topic of possible/impossible, which is an argument for a hypothetical set of events that could have occurred in the past: dark-skinned men from Portugal could have been shipwrecked off the coast of North America in the days of the European explorers.

Crowley and Hawhee use the term "commonplace" in a second way: a commonplace is a statement that circulates within an ideology (network of interpretation). There are commonplaces (i.e. statements) in Melungeon discourse that reveal the rhetors' values and reflect their shared experience. Ideologies and the commonplaces that inhabit them result from life experiences and education. The Melungeon experience, how they suffered under petty bureaucrats like Walter Plecker and endured the ill will of their whiter neighbors, has had an effect on their thinking and their behavior. In the last 35 years people are beginning to admit to being Melungeon. Each person's lived experience is unique. The debates that rage on the websites and the 
email lists both reveal shared commonplaces and show striking differences among individuals. According to Crowley and Hawhee, the need to articulate one's ideology occurs only "when some new ideological construct challenges an older one." ${ }^{30}$ The dialogs and arguments that are circulating are part of the ongoing process of establishing identity and defining terms, and of the attempts by some to reach if not consensus, stasis.

\section{PROOFS FROM LOGOS}

Another important approach to argument in rhetoric is the appeal to logos, rational proofs that can be found by examining issues. Aristotle divided logical proofs into four categories: scientific demonstration, dialectic, rhetoric, and false reasoning. ${ }^{31}$ The most useful of these for the purposes of this analysis is rhetorical reasoning in which some premises are commonplaces from a prevailing ideology and all premises involve human action or belief.

Rhetorical reasoning includes both deduction (moving from a general principle to a specific case where that principle applies) and induction (progress from particulars to universals). Reasoning by enthymeme, "a means of proof within which the rhetor places probable premises together in order to establish a probable conclusion, ${ }^{, 32}$ is very significant in Melungeon discourse. Less rigid than syllogisms in logic, enthymemes still carry power because they are based in community beliefs and often have the force of community commonplaces behind them. An example of an enthymeme from a website called Melungeon Health goes like this:

\footnotetext{
${ }^{30}$ Sharon Crowley and Debra Hawhee, Ancient Rhetorics, 107.

${ }^{31}$ Sharon Crowley and Debra Hawhee, Ancient Rhetorics, 134.

${ }^{32}$ Sharon Crowley and Debra Hawhee, Ancient Rhetorics, 431.
} 
Major Premise: Here is an annotated list of Melungeon diseases.

Minor Premise: You have disease.

Conclusion: Therefore, you must be/might be Melungeon.

Often in a rhetorical argument using an enthymeme, one of the premises is omitted. So the enthymeme above might be stated like this:

Because you have disease, you are a Melungeon.

The same process might occur with other arguments involving certain common surnames, particular physical traits, or a family story about having a "Cherokee" Indian princess as an ancestor.

A second form of logical proof (logos) is use of examples of which there are many kinds: rhetorical, historical, and fictional examples, examples from analogy, and similar/contrary examples. Contemporary rhetors, including Melungeons, are fond of examples, even though Aristotle and his ancient contemporaries preferred enthymemes. Melungeon rhetor Jack Goins likes historical examples that are supported by evidence in official historical documents: the story of the Melungeons who were prohibited from voting in 1846, the recorded land grants in Tennessee to Vardy Collins and Shepard Gibson, the hanging of his ancestor and friends by Confederate vigilantes in 1865. Brent Kennedy, on the other hand, leans toward fictional examples like the story of the Siddi girl sold into slavery or an earlier example he sited of Turkish soldiers abandoned at the Roanoke colony by Sir Francis Drake.

Another category of examples is the maxim. This Melungeon maxim, "Be good, or the Melungeons'll git ya!" is a statement familiar to many in Appalachia, often an attempt by an adult to elicit particular behavior from a child. The final type of example is 
the sign. Different from the semiotic sign, rhetorical signs are physical facts or real events that inevitably or usually accompany some other state of affairs. The conjunction of coppery skin and pale blue eyes could be a sign to a person that she is a Melungeon.

\section{ETHOS AND PATHOS}

A fifth approach for finding appropriate rhetorical arguments was named ethos by Aristotle. Ethos is finding proofs that rely on community assessments of a rhetor's character or reputation. ${ }^{33}$ The ancient Greeks thought that character could be constructed by the moral practices that are habitual for a person; this invented ethos was in addition to having a good reputation, which they termed situated ethos.

Ethos for Melungeons relates directly to their values (ideology); they esteem craftiness, outwitting the law, gaining personal advantage, and personal charisma. Furthermore, individuals within the larger Melungeon community with differing networks of interpretation regard producers of texts (spoken, written, in print, or online) as either having or lacking ethos. According to Crowley and Hawhee, one way that a rhetor can enhance reputation is to "do the homework." Doing homework is the province of scholarly research, yet some in the Melungeon community do not particularly value scholars' methods or conclusions. They highly regard genealogical sleuthing, but eschew other kinds. Other factors influencing ethos that Kress as well as Crowley and Hawhee identify are grammatical person, verb tense and voice, word size, and punctuation. ${ }^{34}$

A sixth approach to finding arguments to use in a rhetorical discourse is through pathos, or emotional appeals. Contemporary rhetors do not admit to using emotion;

\footnotetext{
${ }^{33}$ Sharon Crowley and Debra Hawhee, Ancient Rhetorics, 163.

${ }^{34}$ Gunther Kress, Literacy, 122-137, and Crowley and Hawhee, Ancient Rhetorics, 183-196.
} 
however, in real rhetorical situations, it is often emotion that drives an argument and actually convinces audience members to change their positions. Classical rhetoricians believed that emotions were ways of knowing associated with intellectual processes, and that exploring emotions held heuristic potential. ${ }^{35}$ Emotional appeals are based on the assumption that humans share similar kinds of emotional responses particularly when they (or those close to them) are threatened or when their values are reinforced or challenged.

DruAnna Overbay's narrative about her mother's response to the William Worden article in Saturday Evening Post is effective in showing her readers how strongly her mother's generation felt about the "Melungeon" label. Joanne Pezzullo's statement that appears on the front of the Historical Melungeons website and refers to the way the site is represented on Google is another example of an emotional appeal. She writes: "The person who wrote this review and I have had an ongoing public disagreement about the origins and meaning of Melungeons, what the definition of a Melungeon is, who is a Melungeon and who isn't. He says we are 'determined to resist scientific and historical research'—what scientific research?" ${ }^{36}$ If making her audience wary was her aim, she succeeds with me. She represents those who favor supporting claims about Melungeons with only historical and preferably printed documents only. On the other hand, people who agree with her position—share her ideology—are probably very comfortable with this opening sally. The ancient rhetoricians stipulated that pathos should only be used in introductions or conclusions; Pezzullo's move is appropriate in this regard.

\footnotetext{
${ }^{35}$ Sharon Crowley and Debra Hawhee, Ancient Rhetorics, 208.

${ }^{36}$ Joanne Pezzullo, Front page to Historical Melungeons [Website] (2005); available from http://www.geocities.com/ourmelungeons/front.html; Internet; accessed 20 July 2005.
} 
Audiences may be hostile, indifferent, or accepting. Crowley and Hawhee say research shows that "it is easier to move people who care about an issue than it is to influence those who are indifferent. ${ }^{, 37}$ It is also true that a person's willingness to change her mind depends on the emotional intensity with which she holds to her opinion and how much she believes her identity to be tied to a particular position. I interviewed Melungeon descendant DruAnna Overbay about her perceptions of the websites I had chosen for my analysis. She spent several hours online and then wrote the following in an email message:

It is hard for one to maintain a scholarly stance with so many emotional factors cursing our viewpoints. ... For years we Melungeons have had an identity crisis and now it seems that the internet chat rooms have given us a chance to stand up and say, 'Hey, I am proud of who I am but you (ally or adversary to my theories) don't know “diddly squat" about my story.' And so, we add our stories with some embellishment trying to 'get at the truth' of who we are. ${ }^{38}$

Pathos recognized and acknowledged.

\section{EXTRINSIC PROOFS AND THE SOHPISTIC TOPICS}

The seventh approach that Crowley and Hawhee list concerns extrinsic proofs that are found but not invented; these proofs are not inside in the subject itself but rather are found in the rhetorical situation. Extrinsic proofs include testimony and data. The ancients were suspicious of both; so, too, are the Melungeons. The value of testimony relates to the ethos of the person bearing witness. Data is only as reliable as its source.

\footnotetext{
${ }^{37}$ Sharon Crowley and Debra Hawhee, Ancient Rhetorics, 212.

${ }^{38}$ DruAnna Overbay, "Melungeon Web Sites," email to author, 24 June 2005.
} 
According to Crowley and Hawhee, “[s]tudy of a community's choice of authorities often discloses the values held by its members." ${ }^{, 39}$ How the Melungeons construct the truth about themselves will rest on their choices about what is admissible as evidencedocuments? oral history? DNA test results? rhetorical conjecture? For many years being Melungeon was something a person wanted to hide. Now that talk about Melungeon heritage is occurring, especially on the Internet, it will be interesting to see if they can arrive at consensus.

The final approach to constructing texts is what Crowley and Hawhee term the sophistic topics, the methods of speaking and writing that were part of the pedagogical tradition of the itinerant teachers of rhetoric. These are the totality of rhetoric in the approach of many contemporary composition handbooks that often outline rhetoric as if it consisted merely of the arrangement of essays. The ancients listed these strategies as follows - definition, division, classification, and similarity or comparison. ${ }^{40}$ Of these, definition has been honed to a fine art on Melungeon websites. Many of the pages that pop up in a search engine investigation of the Melungeon landscape include a definition of the term Melungeon written by that site's creator. One definition of 710 words was crafted by a committee in $2000 .{ }^{41}$ Another of 2440 words, authored solo by researcher Jack Goins (who was not a part of the committee that came up with the 2000 definition)

\footnotetext{
${ }^{39}$ Sharon Crowley and Debra Hawhee, Ancient Rhetorics, 224.

${ }^{40}$ Sharon Crowley and Debra Hawhee, Ancient Rhetorics, 242-55.

${ }^{41}$ Karlton Douglas, et al. "Melungeon Definition 2000" [Web site] (2000): available from http://www.geocities.com/mikenassau/definition.htm; Internet; accessed 15 July 2005.
} 
appears as a featured article on two of the encyclopedic sites this chapter will analyze. ${ }^{42}$ Definitions are a favorite sophistic topical form for Melungeon rhetors.

The rhetorical terms and categories outlined in this section in conjunction with Gunther Kress's semiotic approach provide useful tools for the analysis and discussion of websites in this chapter and a threaded email list discussion in the next chapter.

\section{MELUNGEONS: A PRESENCE ON THE INTERNET}

Typing "melungeon" in the search box at Amazon.com leads to thirty-six items. A cursory search in "major newspapers" through Lexis-Nexis turns up articles in the SanDiego Union Tribune, the Times of London (England), The Boston Globe, The Ottowa (Canada) Citizen, The Atlanta Journal-Constitution, The Wall Street Journal, The TimesPicayune of New Orleans, and The Columbus (Ohio) Dispatch. The Melungeons make interesting copy, and they have been featured frequently in the popular press for over a century. What began with Will Allen Dromgoole in The Nashville Sunday American in 1890 has continued unabated.

People who are not even connected to the Melungeons or to Appalachia are appropriating the name and the lore to suit their own purposes: for example, there is a company called Melungeon Records "whose musicians, irrespective of genre, inhabit the margins where traditions collide with innovation, ${ }^{, 43}$ and a recent novel by Madison Smartt Bell called Anything Goes has a main character named Jesse, who never knew his mother and whose father was a drunk. The fact that his mother was Melungeon and that

${ }^{42}$ Jack Goins, "Definition of the Melungeons," [Web site] (2004); available from http://www.melungeon.org/?BISKIT=4180855057\&CONTEXT=cat\&cat=10066; Internet; accessed 15 July 2005.

43 "Melungeon Records," [Website]: available from http://www.melungeonrecords.com/; Internet; accessed 16 July 2005. 
he goes to Hancock County in an attempt to learn something about his mother and Melungeon-ness draws readers into the rich associations of the word and implies he is a kind of lost soul not only in the in the music world, but also in life.

However, the real wealth of information about and by Melungeons is found on the Internet. Quick work with search engines yields links to a phenomenal number of sites:

Table 2

\begin{tabular}{|c|c|c|}
\hline Search Engine & Search term "melungeon" & Search term "melungeons" \\
\hline Google & 56,300 & 18,700 \\
\hline Yahoo & 29,400 & 26,100 \\
\hline AltaVista & 29,500 & 26,000 \\
\hline
\end{tabular}

Print journalists noted as early as 1997 that the Internet was taking on great importance for the Melungeons. Said Richard Starnes in The Ottowa Citizen, "A small group of proud Melungeons has turned to the Internet in efforts to lead their people out of the shadows." ${ }^{44}$ Right after First Union, Starnes had interviewed Darlene Wilson, the creator of the first encyclopedic Melungeon website; at the time of the interview her site was getting 20,000 hits per month. Fred Bleakley in The Wall Street Journal reported that Melungeons hoped the Internet was the key to discovering their origins. ${ }^{45}$ Eight years later the Melungeons are still actively online. The original Melungeon email list has split into at least seven separate discussion forums. The websites are many and varied.

When I began researching the Melungeons in 1999, there were two big sites that served as repositories of information and provided links to more information.

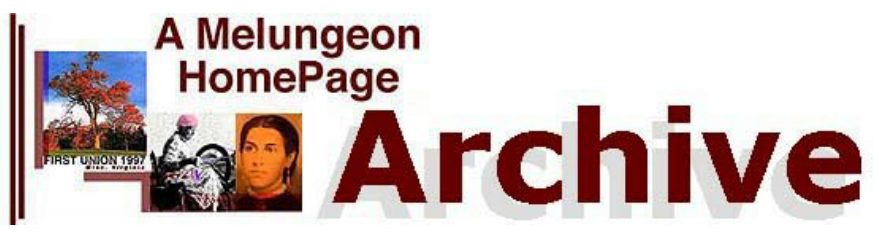

\footnotetext{
${ }^{44}$ Richard Starnes, "Melungeons Seek to Restore Heritage that Racism Killed: A Tiny Mixed-race Tribe Is Using the Internet to Lead Its People Back from Obscurity," The Ottawa Citizen, 2 August 1997, A6.

${ }^{45}$ Fred Bleakley, "On-line: Appalchian Clan Mines Web Sites for Ancestral Clues," The Wall Street Journal, 14 April 1997, B:1, col. 3.
} 
Wilson's site, shown in part and mentioned above, has disappeared. Martha Short's Melungeon Page with its clever jigsaw puzzle background (one screen of this site is shown below) is still available but is not regularly updated. ${ }^{46}$ Three encyclopedic sites

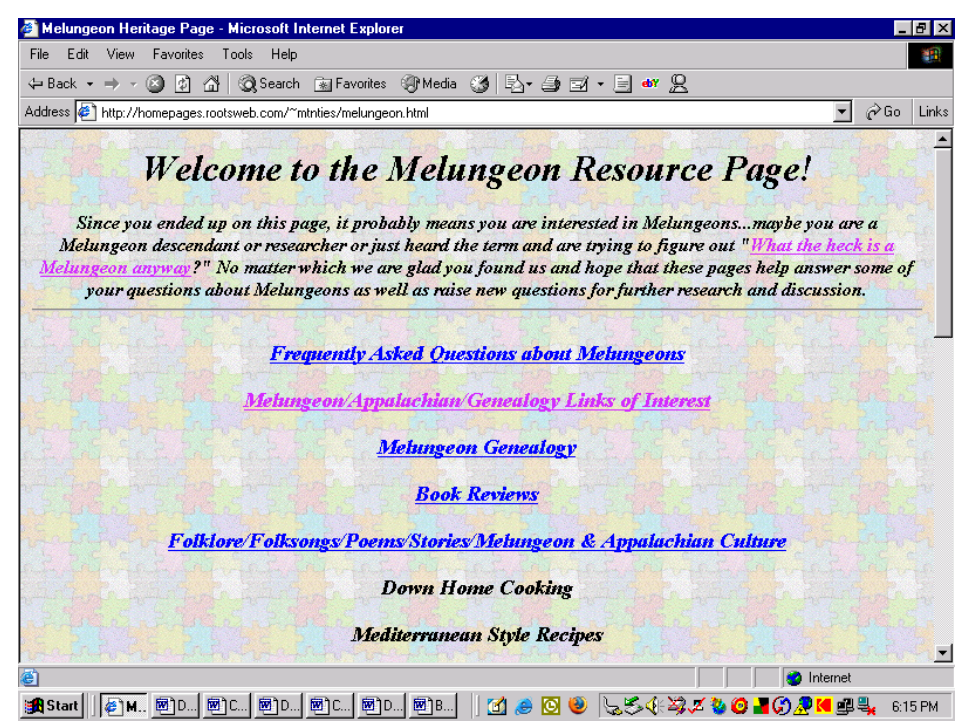

have emerged to fill the needs for information and to make documents available to researchers and interested web surfers. Those three will be a major focus of this chapter. Other Melungeon sites fall into two catgories: the specialty sites (Melungeon Health, The Vardy Community Historical Society, Melungeon Music, etc.) and other personal sites that have a statement about Melungeons. These statements usually showcase a site designer's opinion about the Melungeons, which is relevant because that person thinks he or she may be Melungeon. Many of these pieces of writing are unsigned. A quick search can reveal the flavor of the Melungeon presence to any curious keyboarder.

\footnotetext{
46 "Melungeon Resource Page," [Website] Available from http://homepages.rootsweb.com/ mtnties/melungeon.html; Internet; Accessed 16 July 2005. Martha Short was a student at the Appalachian School of Law in Grundy, VA. She was wounded (shot in the throat) in a shooting that occurred on that campus 16 January 2002 and had a long recovery; this could be the reason her page has been neglected; some screens have not been updated since 2002.
} 


\section{VIEWING http://www.melungeons.com : HOW THIS SITE LOOKS}

In 2002, a site went up that began to fill the gap left by the disappearance of Darlene

Wilson's earlier site. Helen Campbell had bought the domain name

www.melungeons.com and offered to sell it to the Melungeon Heritage Association,

which at that time had a very small site that was primarily a way to advertise upcoming
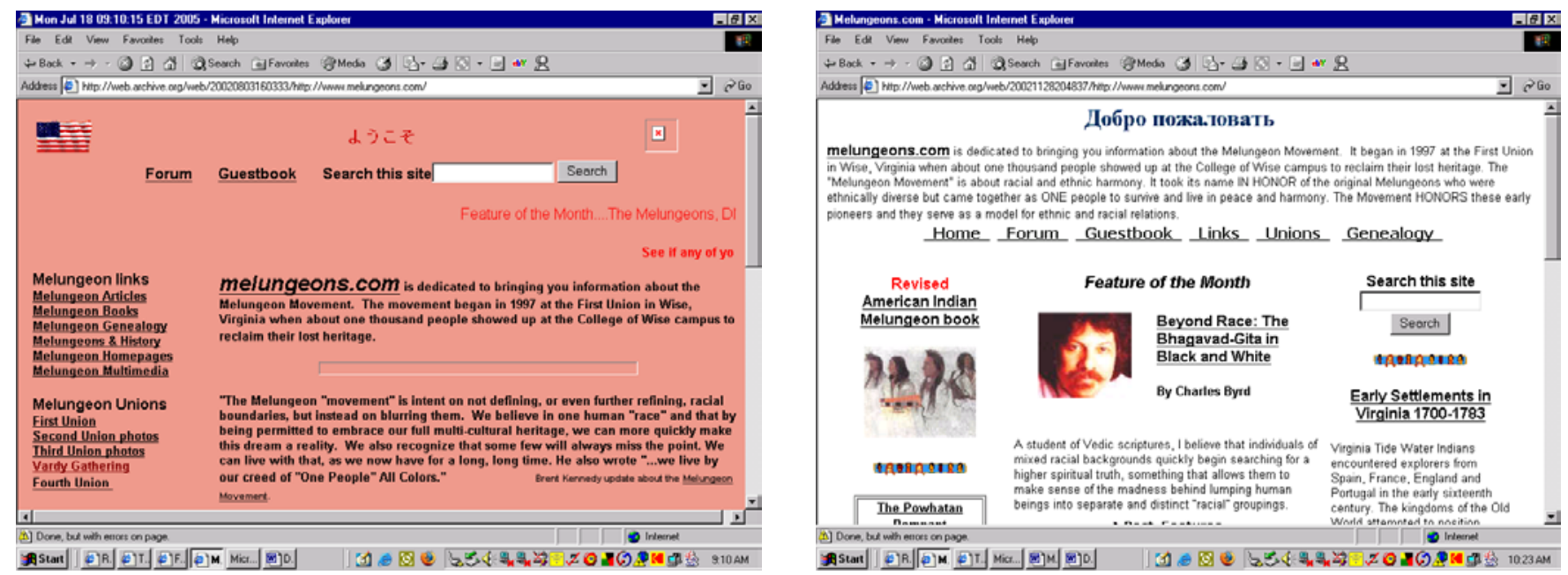

events they sponsored and to answer a few FAQs. At that time, the association was not

interested in buying what Campbell wanted to sell, so she put up a site herself. For at

least two years the webpage had no real title except "melungeons.com" that appeared in

bold face type in the first line of the prominently displayed mission statement. In August

2002 when I analyzed this site for one question on my comprehensive exam, there was a

mauve background (above left), a fluttering American flag in the upper left corner and a

flashing banner that said "welcome" in many languages. The feature of the month, a

hallmark of this site from its inception, was announced in a banner that scrolled across

the screen from right to left. Part of the menu was horizontal as Wilson's menu had been,

and the basic paradigm of the site, foregrounded in a second menu in the left column of

the screen, was emerging. Both menus were point-and-click lists of places to go within 
the site to enter into discussion in a forum, sign the guestbook, or to read further menus listing articles, books, genealogy, and history, as well as information about Melungeon Unions and Gatherings. By December of 2002 (screen shot at right above), the mauve background, the fluttering flag, the left-side menu, and the scrolling ad for the feature of the month were gone. The three-column table format that persists to the present emerged under the mission statement. The welcome in many languages still blinked at the very top.

In January 2003 the drop-down menus appeared. Through August 2003, the site used the white background and the three-column format. In September, the background

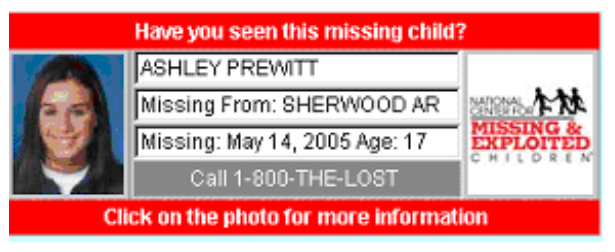
changed to azure and a rectangular box giving changing information about missing children was added. Both of these elements persisted until June 2005. The example below shows the site with the azure background and one of the pulldown menus expanded for viewing.

How did this site, throughout its development, function as a sign articulated by its designer, appropriate to audience and purpose? One of the most noticeable features is the

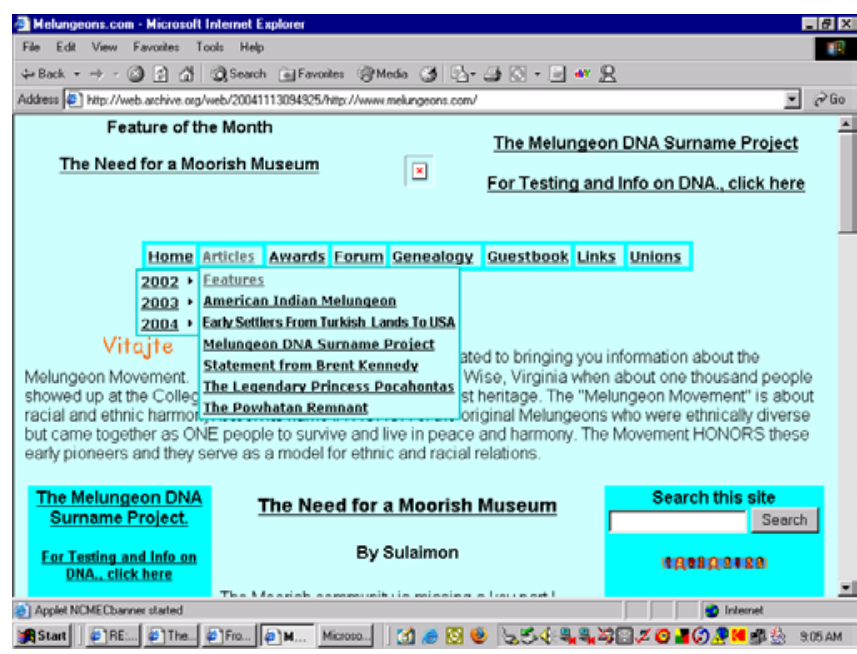

choice of text (i.e. words) over images to convey meaning. Perhaps the fact that the Melungeons and Native Americans came to literacy late in their history makes it necessary to use words to tell their stories. This was a deliberate choice, 
for it is not that Campbell cannot manipulate images; she has many photos from the Unions and Gatherings available on the site. The small bar image in the lower right corner of this azure screen and a drawing in the lefthand column of the white screen on the preceding page hint at Native American ancestry for the Melungeons, an idea that is borne out in number of articles on this site about Native American tribes, families, and migrations.

By December 2003, when the azure background screen shot was taken, another emphasis is visible-DNA. Even if I were viewing the site in an unfamiliar language, the three capital letters would stand out. When Campbell has chosen colors for the background (mauve, azure), they seem to be feminine colors, not hues a man would pick for a website. The evolution of the site's menu over time shows increasing facility with web authoring software. During the first three years of the site's existence, Campbell seemed comfortable with the plan she chose at the outset — no real headline for the site, a clear statement of the purpose, and an expanding number of "articles." Her foci of genealogy, history, news for and about Melungeons, and useful links has been constant.

\section{A STUNNING MAKE-OVER}

In July 2005 the site had a make-over.

Although there is a new look, upon

examination it is clear that the new design is

a re-articulation of the same meanings and

includes many choices that are similar to

earlier versions. The dark blue background

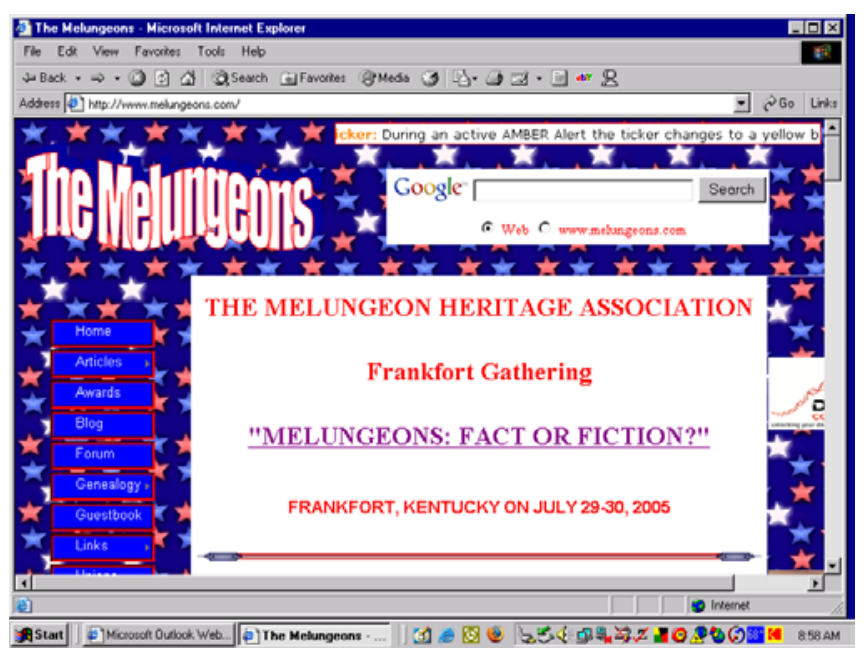


with stars is a patriotic motif, like the flag in earlier incarnations of the page.

The missing child box has been replaced by narrow line at the top giving Amber Alert information as it is available and changing to yellow to let the viewer know that an alert is in progress. The menu, vertical again on the left side, displays drop-down menus when the user rolls her mouse over selected buttons. When pressure on the mouse is released, a star shape appears and then disappears.

There is now a heading in the upper left-hand corner that says simply "The Melungeons." These words are white outlined in red; the font is Arial. The image of the two words was probably done in Word Art with a transparent background to allow the dark blue starry background to show through. The text in the middle section of the threecolumn table arrangement is now a combination of serif and sans serif fonts, and a decorative bar divides the feature of the month article at the top of this column from other articles that appear on the splash page. The mission statement for "The Melungeon Movement," renamed from the earlier "melungeons.com," is at least three quarters of the way to the bottom of this first screen.

Another distinctive feature of Campbell's site is a link to "The Melungeon Song" (http://www.geocities.com/mamashills/LinksandLyrics.html) by aspiring country singer Shalacy Manderson. Although the screen says the viewer will hear Shalacy sing the song, the music is all instrumental. Shalacy, who claims Melungeon heritage, performed at Third Union.

It is interesting to watch how this Campbell's page now loads. The red, white, and blue background appears first, then the Amber Alert bar and Google search box are second. Third the white block for the feature of the month and the buttons of the menu 
come up simultaneously. And, finally, the title pops up; by this time the user may already be reading the text that has appeared or perusing the menu.

This version of the site is less confusing; because there is only one major block of text, the feature of the month, the viewer is inclined to begin reading that article first. The screen looks more sophisticated than the site did at its launching in 2002. Text, more inviting in a narrower column, no longer stretches from margin to margin; the headline gives a clearer focus for the page than the original version had, and the background is crisp. However, there are definite similarities to that early design. The name of the webmaster/creator is still not visible anywhere on the page. The menu is essentially the same as it was at the beginning, and the number of pieces of writing available on the site renders the menu cumbersome especially under "Articles." In addition to a list of essays there are the features of the month—four years' worth of them now. To access these, the user must go to "Articles," then to "Features," then to the each year in turn to finally see the list of essays. If the user is looking for a particular author/scholar or a specific topic, she can use the Google search feature located in a white box in the upper right corner.

Another new feature that demonstrates Campbell's web savvy that appeared sometime in 2005 is a blog, which, like U.T. Law Professor Glenn Reynolds's blog Instapundit, is a list of articles with no comments. These pieces that Campbell points to by hyperlinking have relevance to Melungeon people and to researchers.

\section{AUDIENCE AND CONTEXT: WHO READS THESE MANY TEXTS?}

Melungeon people and researchers - are they the audience for Helen Campbell's "The Melungeons"? Reading the Guestbook shows that many who leave messages there are 
amateur genealogists looking for and/or sharing information. Many guestbook signers are appreciative of the wealth of information the site offers. A few, however, are put off by the fact that a considerable number of the articles, though full of interesting information, show no evidence of documentation —no citations, no footnotes, no bibliographies. These detractors register their dismay in the Guestbook. The site itself reveals that Campbell is dedicated to providing information, but that she herself does not value the conventions of academic discourse. The pieces she has authored as well as others she has published are not documented according to any academic format.

In addition to the lack of documentation, the bibliography of "Melungeon Books" that she provides under the title of "Links" is merely a list of titles often hyperlinked to Amazon.com where the book can be purchased. The list of "Melungeon Articles" is again a list of clickable titles that take the user to a piece of writing somewhere on the web; some of these are also unsigned. On the other hand some articles are scholarly and are presented in conventional formats. The casual web surfer and the amateur genealogist can learn a great deal from exploring this site. An academic researcher may get frustrated trying to figure out who wrote what and dismiss the site as unreliable.

\section{HELEN CAMPBELL'S IDEOLOGY}

Campbell does play to one faction of her Melungeon audience by taking a stand on a contentious issue. She supports Brent Kennedy. One of her early monthly features was the transcription of a speech Kennedy gave at Fourth Union in 2002. Since then, she has consistently published articles he has written, transcriptions of his speeches at the Unions, and articles about him. 
In a piece about her ancestor James Baber titled "In the Shadows of the Blue Ridges," she details her search for information about her Baber ancestors and narrates the epiphany she had when she first read Kennedy's book Melungeons. She felt kinship in her spirit and resonated with his chronicle of his family's experiences of trying to make their way in a racist society. Her unwavering allegiance to Kennedy is based at least in part on this enthymeme: "Dark-skinned Melungeons experienced persecution. My ancestor had very dark skin in the only photograph we have of him and was a source of shame to his daughter. Therefore, my Baber ancestors could have been Melungeon.”

Her latest reference to Kennedy is a citation in her blog pointing the reader to the July 11, 2005, issue of Time that has an article featuring Kennedy's photograph and tells some of his experiences with researching his family lineage using DNA testing. ${ }^{47}$ Campbell also weighs in on a second issue —DNA testing. She posts many articles about it and has links from her site to DNA testing laboratories. A third clear emphasis for Campbell is history of the Native Americans of Colonial Virginia; she has published material about the Powhatans, the Wicocomico Indian Nation, the Cherokee, the Yuchi, and Pocohantas. She works to get

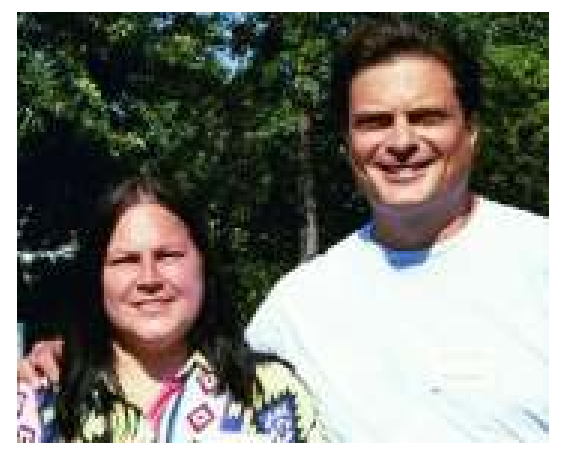
Helen Campbell with Wayne Winkler at Fourth Union in 2002. whatever new material she can find; recently she has featured several articles (six separate pieces) about the Melungeon-Jewish connection predominantly by Elizabeth Hirschman and Donald Panther-Yates.

\footnotetext{
${ }^{47}$ Helen Campbell, “Time.com Can DNA Reveal Your Roots—Jul. 11, 2005” Posted 6 July 2005. Weblog at http://melungeons.blogspot.com/; Internet; accessed 18 July 2005.
} 


\section{A RECOGNIZABLE ETHOS}

Campbell reveals and develops her ethos by what she consistently presents on her site; this is the equivalent of constructing ethos by habitual engagement in moral practices (hexis) ${ }^{48}$ Her diligent gathering of information month after month and her gradual enhancement of her technological expertise are commendable since no one pays her to manage melungeons.com. In addition, under the screen name of "Melungeon Movement," she is a regular contributor to Melungeon- $\mathrm{L}$ where she plays the role of a peacemaker, signing her posts "Melungeon Hugs, Helen." Furthermore, although she is not a regular on the offshoot "Historical Melungeons" email list, she must monitor it closely because she was one of the first to comment when Joanne Pezzullo, the webmaster of the Historical Melungeons website, posted a blog (if one entry can really be termed a blog; there is only one item on it to date). ${ }^{49}$

Helen Campbell said...
Wonderful Blog, Joanne...it's like you have your own "Joanne's Talk
Show."
Are you attending the Melungeon Heritage Association's Kentucky
Gathering in July 2005?
Just in case you don't have the url, it's www.melungeon.org
I'll bookmark your Blog, as Janet stated much good will be inspired and
we do need new resources. Some of the public Melungeon forums are
driving people away, this is sad for those who care deeply about their
ancestors
10:12 PM 6

Campbell, as illustrated in her comment above, is also a staunch supporter of Melungeon Heritage Association events posting information about them on her site and

\footnotetext{
${ }^{48}$ Sharon Crowley and Debra Hawhee, Ancient Rhetorics, 167.

${ }^{49}$ Joanne Pezzullo, "The Real Melungeons," posted 7 June 2005, Weblog at http://therealmelungeons.blogspot.com/; Internet; accessed 18 July 2005.
} 
on Melungeon-L. Crowley and Hawhee indicate that rhetors, and by extension webdesigners, "must seem to be intelligent, to be of good moral character, and to possess good will toward their audiences" and be well-informed about the issues they discuss. ${ }^{50}$ Her work demonstrates her commitment, a continuing quest for fresh information, and good will.

Campbell uses kairos by showcasing the latest research and by keeping a level head in the midst of debates that rage on the email lists. She remains true to the mission statement she has articulated:

melungeons.com is dedicated to bringing you information about the Melungeon Movement. Which began in 1997 at the First Union in Wise, Virginia when about one thousand people showed up at the College of Wise campus to reclaim their lost heritage. [sic] The "Melungeon Movement" is about racial and ethnic harmony. It took its name IN HONOR of the original Melungeons who were ethnically diverse but came together as ONE people to survive and live in peace and harmony. The Movement HONORS these early pioneers and they serve as a model for ethnic and racial relations. ${ }^{51}$

She attends MHA events and photographs presenters and attendees in order to post photos on her website. Unlike many of the amateur website creators who post information about Melungeons or their family connections to Melungeons, Campbell keeps her site current, adding new things as well as adjusting its design at least monthly.

\footnotetext{
${ }^{50}$ Sharon Crowley and Debra Hawhee, Ancient Rhetorics, 170-71.

${ }^{51}$ Helen Campbell, "Mission Statement" from The Melungeons (melungeons.com) [Website] (2002-2005) available from http://www.melungeons.com; Internet; accessed 19 July 2005.
} 


\section{APPLYING RHETORICAL CATEGORIES TO melungeons.com}

In summary, Campbell's website can be viewed as demonstrating a number of rhetorical invention strategies and also as a semiotic articulation. Campbell exhibits kairos in her carpe diem approach to the landscape of Melungeon studies. She has personally come to terms with the raging debates and by virtue of what she includes indicates that she has agreed to disagree with those who vilify Brent Kennedy and that she sees the term "Melungeon" as including more mixed-race people than just those who can trace their ancestry to certain families on Newman's Ridge. The common topic of past conjecture (this is what might have happened if, ...) is evident in many of the pieces of writing she features.

Her site as a whole has characteristics that reveal some uncontested commonplaces of a "Melungeon ideology" by focusing on Appalachia, patriotism (many Melungeon descendants have rendered military service to the United States), genealogy of mixed-race people, connections to Native Americans as well as various intriguing possible origins for off-shore others, ${ }^{52}$ lack of allegiance to conventions of scholarly discourse, the facts of racial discrimination against people of mixed heritage, and valuing of dark-skinned "cousins." Campbell shows willingness to take on some of the contested commonplaces (called "issues" by Crowley and Hawhee) as well. ${ }^{53}$ She does this by choosing to post articles about the DNA studies and DNA testing, to include pieces by both scholars and non-scholarly researchers advancing various theses about origins (Turkic, Portuguese, Jewish/Muslim, Native American, East Indian, Moorish, and

\footnotetext{
52 "Off-shore other" is Darlene Wilson's phrase for the unknown European-Mediterranean Melungeon forebears.

${ }^{53}$ Sharon Crowley and Debra Hawhee, Ancient Rhetorics, 26.
} 
African American), and to exhibit by her choices a fairly broad view of what counts as evidence in the origins debate. People who sign her guestbook show their support of her choices.

Campbell's site does not adhere to a single line of rhetorical reasoning or logos. Rather, it is an aggregate of many arguments. Its inclusiveness is its logos. Campbell's ethos, as shown above, is even-handed and welcoming to people who visit her site. This is in part due to the fact that her treatment of her guest writers is quite polite and formal; there is no chatty introduction for the feature writers and no comments to show favoritism or to get her into trouble. Even Campbell's blog is merely a listing of texts of various sorts. The foregoing details about rhetorical approaches reveal the essence of melungeons.com. The primary invention strategy is the use of data and testimony and therefore not invention at all, but instead an extended example of the use of extrinsic proof. For the ancient rhetoricians, an extrinsic proof was offered in the following ways: ${ }^{54}$

- State it

- Comment on its relevance to the issue

- Comment on its effectiveness

- Make any arguments that are necessary to support it

Campbell stops after the first directive; she only offers data and testimony, not even commenting on the people who are her writers. She forces the readers/viewers to decide for themselves how an essay's information might be relevant to their own searches and questions. She does not presume that her network of interpretation is the same as the

\footnotetext{
${ }^{54}$ Sharon Crowley and Debra Hawhee, Ancient Rhetorics, 222.
} 
ideologies of persons who visit her site. This could be seen as a weakness; however, offering opinions about her writers could also alienate Campbell from her Melungeon audience. Campbell counts on nothing more than the ethos she has already established to recommend her featured essays. As Crowley and Hawhee note, "study of a [rhetor's] choice of authorities often discloses the values held. ${ }^{, 55}$

\section{AUDIENCE AND MEANING}

Crowley and Hawhee emphasize that serious rhetoricians do not subscribe to the notion that an audience is objective. I think Campbell would agree with them. She knows that the Melungeon audience is sharply polarized. She tries to stay on good terms with people representing all the factions as her response to Joanne Pezzullo's blog shows, yet she realizes that she will never please everyone. She doesn't even try. And, even though academics would fault her for her lack of careful documentation and her failure to insist that writers who post their work on her site document their assertions, she does understand the Melungeon community and what counts as proof for many of them. On Melungeon-L, a scholarly approach and citation of usual printed sources, can be the kiss of death ${ }^{56}$ Campbell is comfortable with her own decisions; they represent the meaning she wants to convey.

This meaning is what Kress would call semiotic work. One sign-maker, the creator/designer, represents meaning in a particular way. Then, subsequent to the making, a receiver/viewer of the sign interprets it to make meaning of his or her own. Helen

\footnotetext{
${ }^{55}$ Sharon Crowley and Debra Hawhee, Ancient Rhetorics, 224.

${ }^{56}$ I found this out first hand trying to use dictionary etymological data in a discussion about the meaning of the word "mahala." There was lots of flaming over that one; I learned to keep quiet.
} 
Campbell's website is a multi-modal construction of meaning that, although text-heavy, is conveyed through a screen image delivered to its viewers over the Internet. The blue starry background, the simple headline rendered as a Word-Art image, the button menu with mouseover features, clickable icons, a link to music files, its paradigm of featured texts and links to more print and web texts show Campbell's awareness of available modes and of their affordances. It is interesting to note that she does not use photographs or drawings except in her photo galleries.

She demonstrates awareness of the social climate of her Melungeon audience by remaining steadfastly faithful to the purpose for the Melungeon Movement she stated from the outset. Her personally created and maintained site is situated in the emerging discourse of Melungeon studies. Campbell takes full responsibility for the articulation of meaning that she creates; however, she leaves the other half of the semiotic scheme, interpretation, to viewers. She does not prescribe a reading path through her site, but rather allows site viewers to scan the screen as the various portions load and then choose their own paths, make their own meanings. The non-refereed space of the World Wide Web is where Campbell feels at home.

JOANNE PEZZULLO'S HISTORICAL MELUNGEONS:

\section{A PUGNACIOUS PRESENCE}

When I first began serious research on the Melungeons in 1999, one of the debates then underway on Melungeon-L was "Who can be included in the group labeled 'Melungeons'?" My final chapter will focus on a discussion thread from that list that took place on Melungeon-L early in 2002. This threaded discussion showed through linguistic 
markers that there were insiders, people who could trace their ancestry to the original Melungeon families that settled in the area of Newman's Ridge in the early years of the $19^{\text {th }}$ century, and there were outsiders. All the people who were "insiders" in that 2002 list discussion have now, for the most part, stopped contributing to Melungeon- $\mathrm{L}$ and moved to a new list that is accessible through a website titled Historical Melungeons and Their Kinfolks. According to Jack Goins, Joanne Pezzullo, "a renowned Appalachian and Melungeon researcher," is the creator and webmaster of Historical Melungeons, even though her name does not appear anywhere on the site itself except as the author of one of the articles listed in its Table of Contents. ${ }^{57}$

Historical Melungeons is referenced in a posting to Melungeon- $\mathrm{L}$ in late September 2002. The "WayBackMachine" at the Internet Archive logs the site's first revision on November 28, 2002. The first screen in the archive is a white screen with blue text in Comic Sans font. The writer of the text on the screen, whom I assume to be Pezzullo, is complaining about the way the site was described in the DMOZ Open Directory Project.

If you have been directed to this page via DMOZ Open Directory Project or google directory then you have found the following description of this website:

"Our Melungeons: Taking Back Our Heritage - Here is a site from Melungeons determined to resist scientific and historical research and maintain their old legends as truth."

The person who wrote this review and I have had an ongoing public disagreement about the origins and meaning of Melungeons, what the definition of a Melungeon is, who is a Melungeon and who isn't.

He says we are "determined to resist scientific and historical research"--- what scientific research? A DNA study that has not even been released yet -- that was

\footnotetext{
${ }^{57}$ Jack Goins, [Website] (2005); available from http://www.jgoins.com/joannejim.htm; Internet; access 21 July 2005.
} 
done on "self-defined" Melungeons? Does he seriously consider that a scientific study?

Or a blood study test almost 60 years old? A census study done in 1950? This same study talks about how many Gibsons were in Wise County yet does not have any idea if they were all related [they weren't] [sic]

Is this what this editor is referring to by "scientific"? How about "historical research"? The Melungeons have no history, to the contrary they have repeatedly said there is no such thing-- they were "dubbed" Melungeon by their neighbors. It is a made up word. Their descendants have been left no history. They have no mounds to search, no bowls, no villages, no towns.

Melungeons are probably the MOST controversial subject you will come across in genealogy and I believe everyone is entitled to form their own opinion. Here is another side to the story. One you probably haven't seen. ${ }^{58}$

Such a statement may be immediately inviting to someone who knows who "he" is, but it makes an uninitiated viewer uneasy. This sign signifies that this website stands in the midst of controversy, and, as Gunther Kress would argue, is apt for the message intended by its maker. Just below this text on the page is a large blue button with the word "enter" in capital letters. The emotional intensity of the text, as noted in my earlier discussion about how pathos is used in Melungeon discourse, might even discourage some viewers from going any further.

For several years, this blue text was the entrance to the site, and it is still available at http://www.geocities.com/ourmelungeons/. However, the "front" portal that appears today when a person enters from Google or another search engine is different (shown on the next page). The explanation of the site in Google has changed; it is currently a brief list of some of the historical articles available on the site. It is interesting that Pezzullo has left her "Put-up-yer-dukes" text visible on the web when the situation that distressed

\footnotetext{
${ }^{58}$ Preface page, Historical Melungeons [Website] (2002); available from http://www.geocities.com/ourmelungeons/; Internet; accessed 20 July 2005.
} 
her has been rectified. Perhaps she wants the person she disagrees with to be aware that their difference of opinion about the purpose of her site persists.

\section{HOW THIS SITE LOOKS}

The front page has a marbleized background with a title box that simulates tree bark prominently displayed at the top of the screen. When the page loads in Windows Internet Explorer (but not in Mozilla Firefox) it comes up in a

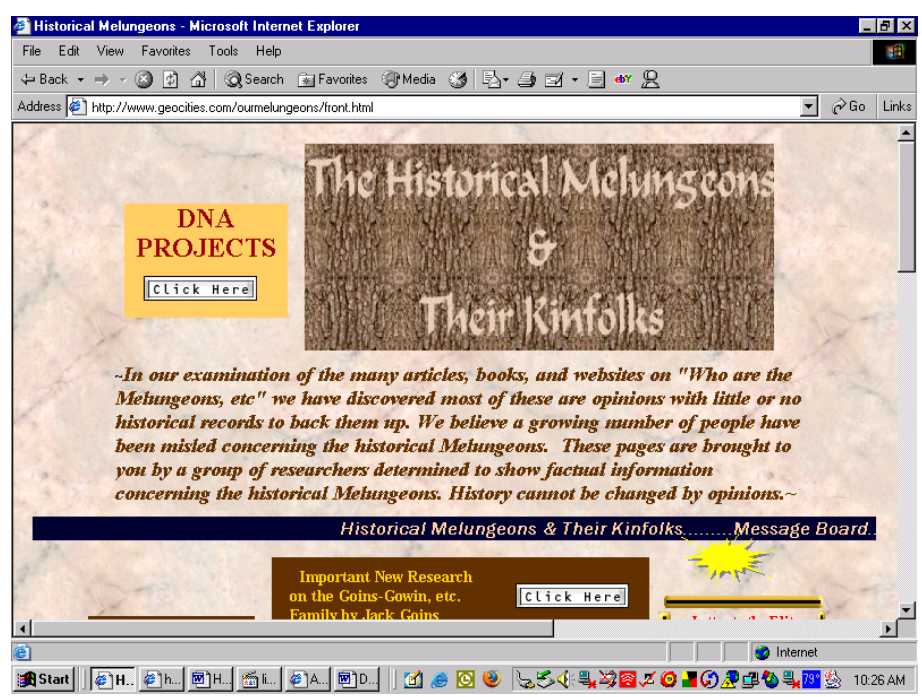

reverse dissolve transition - tiny dots change into the elements of text and image shown above. Scrolling down reveals that the page is divided into thirds: the top third displays the title and introductory text in a large horizontal rectangle. The dark bar just below has scrolling messages about the site that reveal the emphases of its designer. A yellow box

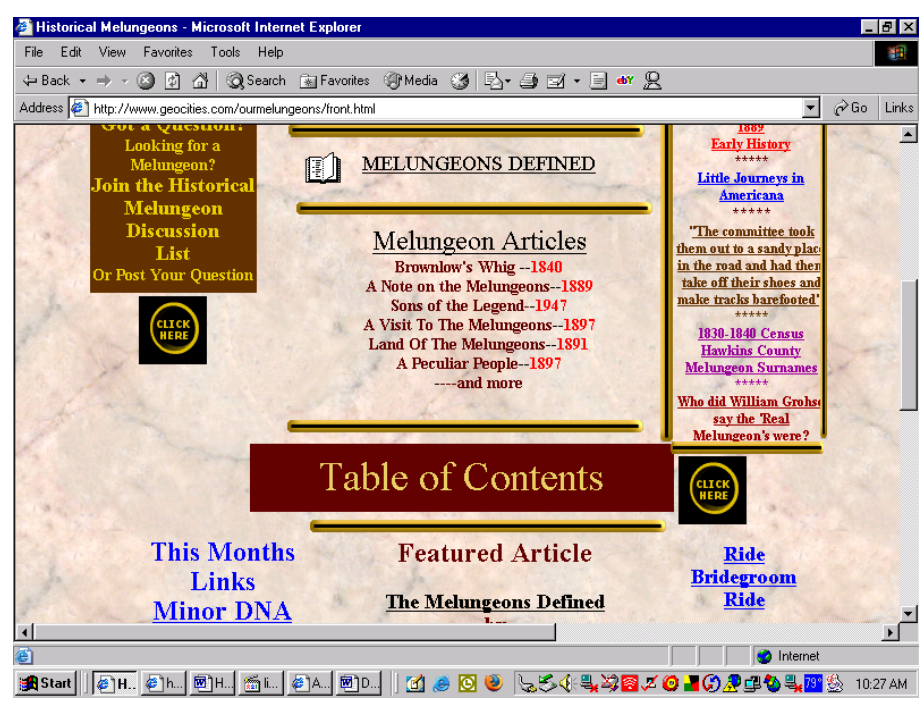

announcing DNA projects gets

prominent placement in the upper

left corner of the screen, the first

place that a reader of printed

pages would look for important

information. The middle third of

the page contains text boxes and

lists that direct the viewer to the 
several different places where the content of the site can be accessed: a table of contents, a list of "Melungeon" articles, a link to the Historical Melungeons Discussion List, a definition of Melungeons, and, on the right, a box with call-outs from articles that invite the viewer to click to find more information. Heavy gold and black bars separate sections of this middle portion of the page. Some hyperlinks are underlined; a "Click Here" button indicates others. Although shades of brown and yellow are used for the boxes, there is a lack of unity, for the colors don't match exactly. Furthermore, some of the underlined links are black; others are blue. There is no menu, a feature many viewers have come to expect on the left or across the top of the screen.

The bottom third of the front page has several images; a photograph of a sign denoting the boundary between Scott County, Virginia, and Hancock County, Tennessee, a moving quill pen and page icon that invites visitors to sign the site's guestbook, and a mailbox with a flashing sign that says, "Send Us Mail." In addition there is a block of text that reveals the site's purpose statement, and a white box that

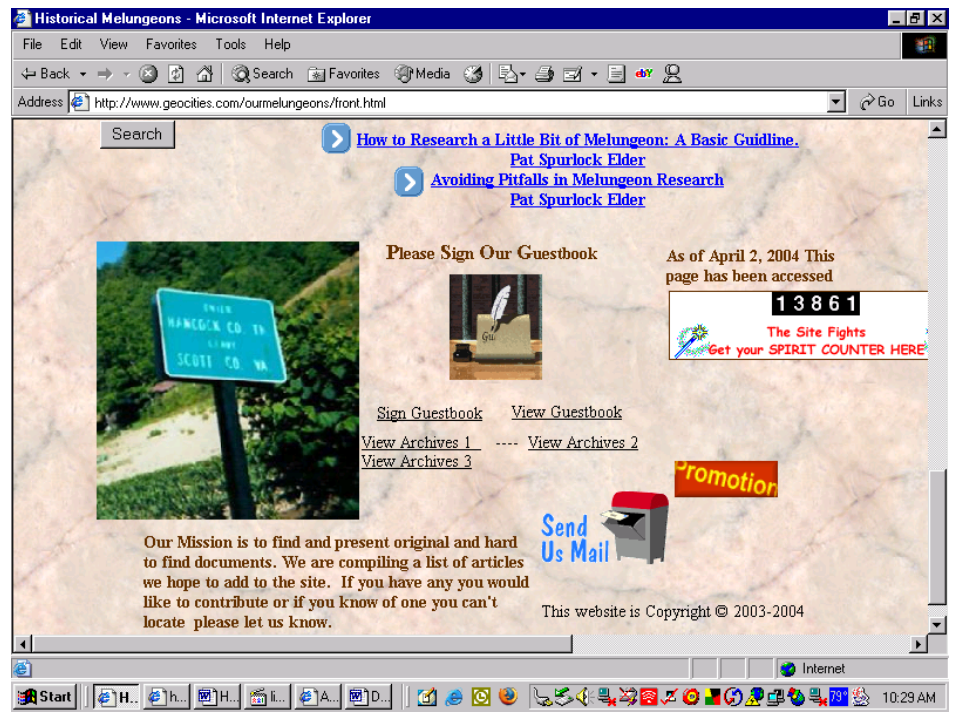
contains a counter. The paradigm of this site is partly visible, but from the first screen it's not entirely clear how the page is structured underneath this interface.

Except for the headline in its box at the very top of the screen, almost all the text is Times New Roman bold. There is a "search this site" feature, but exploring is the best 
way to discover both the contents and the organization. There is no evident place to begin an exploration; a viewer must simply start at a point of her choosing.

Even though other elements seem more prominent, in the absence of a true menu, a seasoned web surfer might choose the Table of Contents, which proves to be a grid listing titles and sometimes the authors of contemporary (not historical) texts. The background color for the table is peach and the text, all in Times New Roman, is dark red. Some titles are large and bold; others are small. All are underlined to indicate that they are hyperlinks to other web texts.

\section{WHAT THIS SITE MEANS}

This site seems visually chaotic, as there is no obvious use of a columnar or block design. Its meaning as a sign is not clear from the visual display. Only when the two blocks of text on the screen are read and understood, does the intent of the designer become apparent. Pezzullo's statement near the top of the page, just under the headline, asserts that most other internet sites about Melungeons lack "historical records" to back their claims. This problem has caused people to be misled. She promises something different: "These pages are brought to you by a group of researchers determined to show factual information concerning the historical Melungeons. History cannot be changed by opinions. ${ }^{59}$ For me an irony emerges; historical writing in secondary sources is very opinionated; only primary sources—-such as voting lists, birth and death certificates, deeds, military documents and the like (which are not reproduced on the Historical Melungeons site) — are without the taint of writers' biases.

\footnotetext{
${ }^{59}$ Joanne Pezzullo, http://www.geocities.com/ourmelungeons/front.html; accessed 20 July 2005.
} 
The mission statement of this site, located at the bottom of the screen when the viewer scrolls all the way to the bottom, is in a prominent position. Bottom and center, says Gunther Kress, has the meaning potential of "'grounded,' 'of this earth,' 'the empirical' meanings which might be charcterised as 'real." 60 The introductory material, placed near the top of the screen just below the headline has an opposite meaning potential, '“not of this earth,' 'that which is desired,' meanings which might be characterized as “ideal." ${ }^{\prime 61}$ These are potential meanings, not necessary meanings, warns Kress; they are possibilities for making meaning. In the case of this website, this theory works, for what the site-maker hopes to do for the audience, her ideal, is stated at the top. Her definite and clearly defined mission, providing documents, is placed at the bottom, where she writes, "Our mission is to find and present original and hard to find [sic] documents.",62

The text-heavy nature of this website underscores what Pezzullo articulates as its mission. Kress notes in his book that "the signifier(s) chosen will always be apt for the signifieds. ... [A]nd from the shape of the signifier the reader/viewer/hearer will form their hypothesis about the sign as a whole." ${ }^{.63}$ The screen is her mode, but she is not maximizing its affordances. Pezzullo and the group she represents, although they all use the Internet to communicate with each other and the broader Melungeon research community, inhabit an ideology of "text only." For them written words on pages are the most valuable kind of evidence. If words (more precisely words they agree with) have been written somewhere in the "historical" past, those words are true. Pezzullo's choice,

\footnotetext{
${ }^{60}$ Gunther Kress, Literacy, 69.

${ }^{61}$ Gunther Kress, Literacy, 69.

${ }^{62}$ Joanne Pezzullo, http://www.geocities.com/ourmelungeons/front.html; accessed 20 July 2005.

${ }^{63}$ Gunther Kress, Literacy, 43.
} 
using words on the screen instead of images, is her articulation of the enthymeme that is the basis for her group, the Melungeon Research Committee, and the website. My understanding of her enthymeme is this:

Major Premise: Truth is found in written documents.

Minor Premise: Written documents about Melungeons exist from 1813.

Conclusion: These written documents (that we present here) demonstrate truth.

There are several additional ironies here. First, Pezzullo only chooses certain documents, ones that locate Melungeons as descendants of a handful of people who settled on Newman's Ridge in Hancock County, Tennessee, in the early 1800s. She does not select Melanie Sovine's 1982 doctoral dissertation from the University of Kentucky as one of her privileged documents. Sovine, as I noted earlier, alleges that many of the articles in the popular press, the very articles that Pezzullo is so zealous to collect on her website to establish the credibility of her thesis, represent Melungeons falsely. ${ }^{64}$ As I previously noted, Sovine attacks three commonly held assumptions about Melungeons: 1) Melungeons are of indeterminate origin; 2) there is such a thing as a collective Melungeon identity; and 3) Melungeon population is centered on Newman's Ridge. ${ }^{65}$ In Sovine's assessment, none of these assumptions - all of which are prevalent in printed materials about the Melungeons (prior to 1982) - is true. She claims in her dissertation that the integrity of what she terms a "media-created explanatory model" has power that is never questioned, and so the myths are perpetuated. ${ }^{66}$ Sovine's painstakingly

\footnotetext{
${ }^{64}$ Melanie Sovine, "The Mysterious Melungeons: A Critique of the Mythical Image," (Ph.D. diss., University of Kentucky, 1982) 2.

${ }^{65}$ Melanie Sovine, "Mysterious Melungeons," 50.

${ }^{66}$ Melanie Sovine, "Mysterious Melungeons," 55.
} 
researched and thoughtfully presented thesis adroitly undermines the premise on which Pezzullo grounds her presentation.

It is true that Pezzullo has gathered an impressive array of previously published articles onto her site -29 of them to be exact. However, all these are presented as if they have the same weight; there is no attempt to indicate which ones are very significant and which are less so. Some of these are the "classics" in Melungeon research, such as the short piece from Littell's Living Age (1848), the four articles by Will Allen Dromgoole (1890), a transcript of Swan Burnett's 1889 speech, William Worden's Saturday Evening Post piece (1947), Louise Davis's 1963 article from the Nashville Tennessean Sunday Magazine. However, in addition to these, she has articles from little known newspapers such as the Marion Daily Star, the Trenton Times, the Zanesville, Ohio, Times Recorder, and the Denton Journal of Denton, Maryland. These various pieces are not even listed in a discernable order — not by date, not alphabetically by title or by author. What she does do is introduce the entire list with this paragraph:

These are excerpts from old newspapers and magazines. Most, if not all, of the articles refer to the Melungeons on Newman's Ridge. Some Melungeon researchers have made character assassinations on some of the authors of these articles in an attempt to discredit the articles. We believe that while the stories may vary [which they should] they basically all tell the same story. The reader can judge for himself. [sic $]^{67}$

\footnotetext{
${ }^{67}$ Joanne Pezzullo, Historical Melungeons, http://www.geocities.com/ourmelungeons/front.html, 21 July 2005.
} 
The most important part of this statement is the phrase "the Melungeons of Newman's Ridge," for Pezzullo and her group do not allow that any others rate membership. Another key word is "old," although "old" is never defined.

A second irony is the title of the group that Pezzullo says she represents, the Melungeon Research Committee. This site and Pezzullo are decidedly against Brent Kennedy and everything he says, does, or supports. They allege that he has no right to call himself a Melungeon, because he does not descend from the Newman's Ridge ancestors. Furthermore, they see him as being too inclusive; he encourages too many people to claim "Melungeon" heritage. One perceives from the outset that this site is not a place where dissenting viewpoints will be displayed. All contemporary writers that Pezzullo recruits will march to the same drummer. The irony resides in the choice of the group name, because in the 1990s, after the publication of his book, Brent Kennedy gathered a group of scholars and lay genealogists that he called "The Melungeon Research Committee." That Pezzullo and the rest of the "historical Melungeons" should adopt the name he chose seems quite strange. The attitudes of the "historical Melungeons" to Kennedy is expressed in an article on the site by Jim Callahan, author of Lest We Forget, who is a direct descendant of the legendary moonshiner Mahala Mullins. Writes Callahan,

Sometime in the early part of the past decade a new educated, articulate and entertaining individual named Kennedy appeared on the Melungeon scene in the Wise County, Virginia area [sic]. He wrote a book on Melungeons and managed to charm his audiences on the speaking circuit. Many of his theories were pure speculation to which he readily admitted. The media and audiences 
embraced his oozing charisma. They cared little about documented facts. The movement was suddenly in a big parade and he was the Grand Marshal. ...

Early in the Wise movement, unscientific speculation arose that Melungeons might have an origin connected to Turkey. The reality was that any country, with the right salesmanship, would embrace the opportunity to be the source of possible early discoverers of the North American continent. The Turkish theory was exploited for several trips with Kennedy and several of his followers getting vacations to the Eastern Mediterranean country. ${ }^{68}$

This prose does not even make very good sense, but the venom is clear. Callahan's essay continues to talk about physical characteristics that Kennedy would often mention in

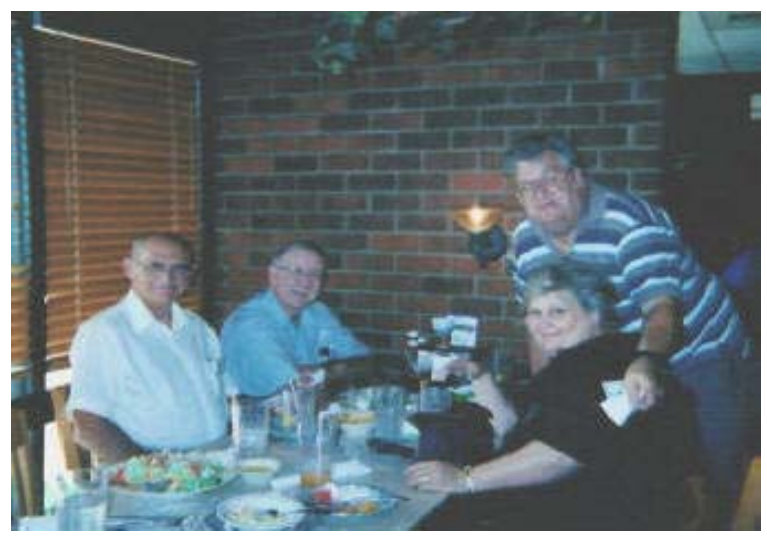

Seated left to right: Jack Goins, Jim Callahan, Joanne Pezzullo. Standing: Cleland Thorpe. Could these individuals be the Melungeon Research Committee?

speeches as well as Mediterranean diseases such as sarcoidosis, the disease that was Kennedy's wake-up call to his Middle Eastern genetic heritage. This expressed position is not just Callahan's opinion; I believe that the entire group including Pezzullo endorses this anti-Brent Kennedy stance. Recently, on one of the email lists I read a posting about the "historical Melungeon researchers"; that list included Jack Goins, Pat Elder, and Jim

\footnotetext{
${ }^{68}$ Jim Callahan, "The Melungeon Movement in the Past Decade," available at http://www.geocities.com/ourmelungeons/feature.html; Internet; accessed 21 July 2005.
} 
Callahan; the complaint was that they were not being included in the program of the July 2005 Melungeon Heritage Association gathering in Frankfort, Kentucky.

\section{TABLE OF CONTENTS POINTS USERS TO ADDITIONAL INFORMATION}

In addition to Callahan's article the Table of Contents allows viewers to access 31 other places within the site. Some of these, such as the clickable title Historical Articles, are accessible from the main page, but most are not. The majority are essays written by contemporary writers about Melungeons or Melungeon research issues. Other items are maps, a small photo album, and links to genealogy sites. Clicking on "The Most Famous Melungeon Mahala Mullins" [sic] leads to a photograph of her cabin when it was still on top of Newman's Ridge, transcriptions of two different versions of her obituary, and three other articles about her moonshining. While reading these, the viewer hears that Tennessee theme song, "Rocky Top." In this case, Pezzullo is capitalizing on three affordances of web design: text, image, and music.

One very interesting section of the site, pointed to in the Table of Contents by the title "Geographical Location Of [sic] the Melungeons Or 'Who Are The [sic] Ridge Onlys?" is a list of brief quotations from 27 different sources. All these brief segments locate Melungeons on Newman's Ridge. This list is prefaced by these comments that are italicized for emphasis. I assume that Pezzullo wrote this introduction [italics hers].

There seems to be a group of 'Self-Identified" Melungeons who have chosen to use character assassinations and name calling rather than present historical documents to prove their case. They apparently need to 'sell' the idea 
that anyone who 'senses' or 'feels' Melungeon are [sic] therefore descendants of the Melungeons.

It is not the intent of the Melungeon Research Committee to declare who is or who is not a Melungeon but to present factual evidence to the Melungeon researcher so they [sic] may decide for themselves. Beginning in 1849 the researchers have headed to Newman's Ridge to find the Melungeons. It is not a 'handful' of current researchers who believe the 'Ridge' was their ancestral home. If anyone can present documentation otherwise we will gladly add it here. ${ }^{69}$ These paragraphs hint at not only the ideology of this group, the Melungeon Research Committee, but also at the issue of what counts as proof in Melungeon research. This is a true issue in the rhetorical sense as there is no consensus about it. There has never even been any agreement to disagree on this point. These paragraphs, similar to some of Pezzullo's other texts, display disregard for standard conventions of grammar and punctuation.

\section{AN ADMIRING AUDIENCE}

Next comes the question of audience—whom does Pezzullo see as being her audience? From the entries in the archived guestbook, it seems that the audience for this site is people who are searching for genealogical information and others who want information about the Melungeons. I couldn't help but note that most of the people I designated as "insiders" in my linguistic analysis of the discussion on Melungeon- $\mathrm{L}$ weighed in with very positive comments about the site in the guestbook. "Joanne" (Pezzullo herself)

\footnotetext{
${ }^{69}$ Joanne Pezzullo, "Geographical Location of the Melungeons or 'Who Are the Ridge Onlys?"” available at http://www.geocities.com/ourmelungeons/onlies.html; Internet; accessed 21 July 2005.
} 
posted to thank people who had contributed and supported her in construction of the site. Crowley points out that audiences do not respond to a rhetorical proposition out of context. ${ }^{70}$ For the larger audience that the site may reach on the Internet, the ideological distinctions that Pezzullo is making may have little meaning. However, to people in the know, she is staking out a very particular territory.

\section{ETHOS}

Pezzullo's relationship to the main issues that the site addresses is made clear from her comments on the preface page, the front page of the site, and in the introductions to various parts of it. She thinks that only people who can trace their lines back to early Newman's Ridge families can be labeled Melungeons, and, furthermore, the only evidence that counts is printed or written documents. Her ethos-evidenced in both the material on the Historical Melungeons site, her single blog entry, and in her posts to various email discussion lists - is adversarial. Jack Goins, who has a good reputation (more about Goins later in the next chapter), calls her a renowned Appalachian and Melungeon researcher. However, not even his recommendation mitigates the persona she presents online. Pezzullo's hexis, her habitual practices, demonstrate ill will toward those who disagree with her and no inclination to listen to opposing points of view. Her network of interpretation is so rigid that she cannot imagine another position having merit.

Three years ago the "historical" Melungeons were participating on Melungeon-L; they often disagreed with others who posted to that forum including Brent Kennedy, but

\footnotetext{
${ }^{70}$ Sharon Crowley and Debra Hawhee, Ancient Rhetorics, 110.
} 
they were participating. Something made them decide that they wanted their own website and their own email list where there was less abrasion from people who disagree with them and more "truth." As Crowley notes, "the need to articulate deeply held ideological beliefs comes about only when some new ideological construct challenges an older one." 71 The "historical" Melungeons were no longer comfortable being a part of the larger Melungeon research and discourse community, so they moved to a new and more comfortable space.

\section{USING RHETORICAL INVENTION STRATEGIES}

In summary, it is clear that like Campbell's site, Pezzullo's page both demonstrates several rhetorical invention strategies and functions as a semiotic articulation of meaning. Pezzullo's site is much narrower in scope since it so clearly takes a particular position on the issues of who can be included in the Melungeon group and what counts as evidence.

Pezzullo's position employs kairos because it does take advantage of the high level of interest in Melungeons and the fact that many people are doing genealogical research online. She does not use stasis or the common topic of past/future conjecture. However, she does use the other two common topics - degree and possibility. The question "What is better?" yields, for Pezzullo, this answer: good equals truth, and truth means actual writings. She places a very high value on the traditional literacy of reading and writing, even though many of the people she is seeking to legitimize were illiterate. Written documents, including items from the popular press, for her, and supposedly for

\footnotetext{
${ }^{71}$ Sharon Crowley and Debra Hawhee, Ancient Rhetorics, 107.
} 
the unidentified members of the Melungeon Research Committee, have always counted as truth and will continue to count as truth into the foreseeable future. As for possibility, I suspect she would say that it is impossible to change her mind on the two issues upon which she bases her ideology. It would be interesting to ask her where she draws the line, for I am certain that she would not consider anything written by Brent Kennedy or by persons who support his point of view to be true or useful, yet Kennedy's work meets one of her criteria as it is definitely printed in both scholarly and popular venues.

The primary rhetorical focus of the site, its logos, is the ideology that underlies it. Pezzullo presents many historical examples in the form of texts from popular periodicals. The community authorities she chooses, like Pat Elder, Jim Callahan, and Jack Goins, all share her literalist view of texts and the belief that true Melungeons must trace their lineage to Newman's Ridge in Hancock County. Pezzullo uses pathos by writing incendiary diatribes that elicit allegiance from like-minded folk and disdain from others. Her language is informal, but that does not enhance her ethos, for her condescending attitude toward those with whom she disagrees is not even thinly veiled. The only scholars she references on her site are genealogist Virginia DeMarce and author Pat Spurlock Elder, both of whom value the written record over family oral histories or possible explanations for Melungeon origins based on DNA evidence. It is ironic to note that the articles Pezzullo presents as "gospel" about the Melungeons are, in many cases, based on oral accounts or on the Dromgoole pieces. As Kress points out, semiotic articulations must be treated as "motivated conjunctions of meaning and form, ... [T]he 
shape of the sign gives me a strong indication of the interest of the maker of the sign., ${ }^{, 72}$ Joanne Pezzullo's definite views are clearly represented by her website.

\section{A SITE BY THE MELUNGEON HERITAGE ASSOCIATION:}

\section{A CLEAR MISSION STATEMENT}

As the Melungeon Heritage Association has grown, so has its website evolved; yet certain elements, like the group's mission statement, slogan, and ethos, have been constant. In the beginning an individual on the MHA board volunteered to give the group a presence on the web by posting two modest screens at Geocities with the URL http://www.geocities.com/BourbonStreet/Inn/1024/. This address still works in that a viewer can go to it, click on the MHA logo, and arrive at the current site http://www.melungeon.org/. The first instance of the early version is logged by the WayBackMachine on October 23, 1999, and the first revision is a year later.

The first screen of the early site announced the forming of the MHA, stated its purpose, and listed goals. The association has remained true to its mission from then until now, and Wayne Winkler, the current vice-president and for

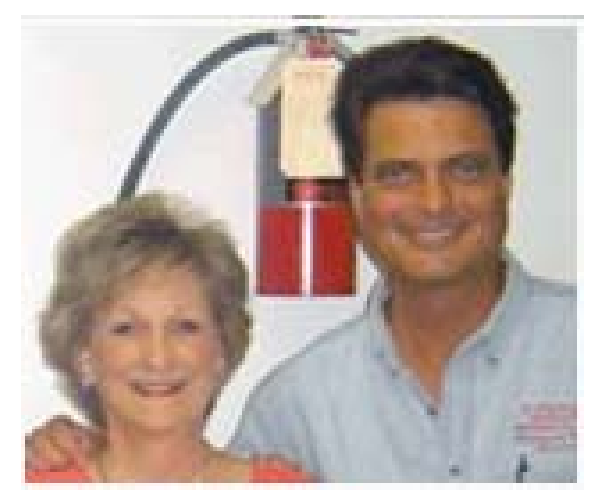

Wayne Winkler, MHA webmaster, with DruAnna Overbay at Fifth Union in Kingsport, TN, June 2004.

the last year the webmaster, has been an articulate spokesman for the group on the website, in discussions at Melungeon-L, on the speaking circuit, and on National Public Radio. Winkler's position as program director of WETS-FM, the NPR affiliate at East

\footnotetext{
${ }^{72}$ Gunther Kress, Literacy, 145.
} 
Tennessee State University, has given him a platform and the resources to produce a short segment on the Melungeons that aired on All Things Considered in September 1997. Winkler says in his book, "I interviewed Brent Kennedy (and some of his critics) and produced a radio piece." ${ }^{, 73}$ That brief introduction led to an hour-long radio documentary, "Sons and Daughters of the Legend," that, although prepared for airing on WETS-FM, was picked up by many NPR stations around the country. For both pieces, NPR producers stipulated that all sides of the story had to be presented. This inclusive emphasis, giving space and time to all voices in the debates, is also a primary goal of the MHA.

The stated purpose of the Melungeon Heritage Association was on the early versions of the website and is still prominently displayed:

Our purpose is to document and preserve the heritage and cultural legacy of mixed-ancestry peoples in or associated with the southern Appalachians. While our focus will be on those of Melungeon heritage, we will not restrict ourselves to

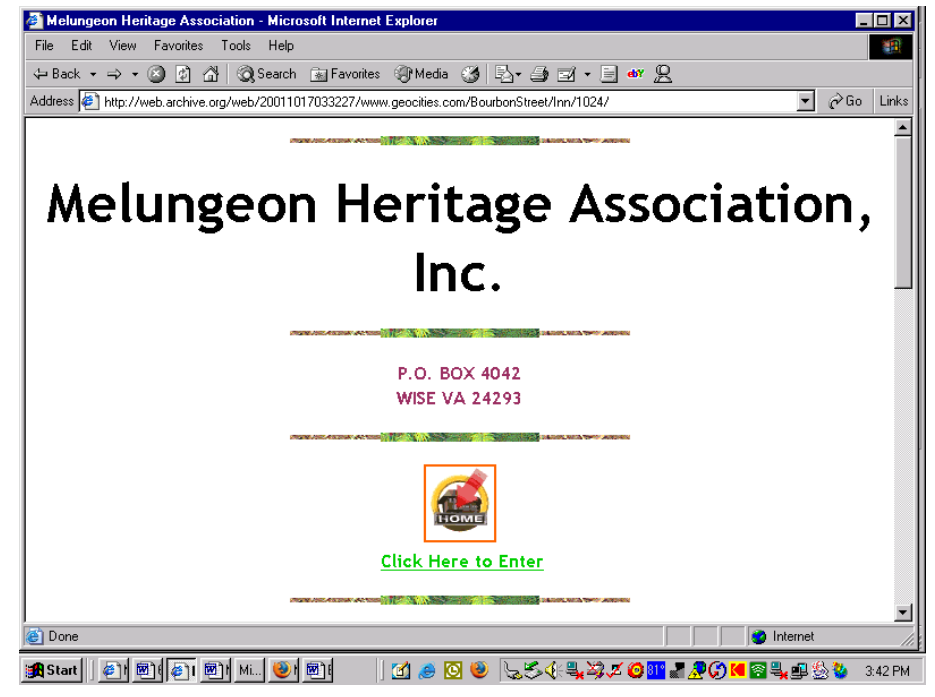

honoring only this group. We firmly believe in the dignity of all such mixed ancestry groups of southern Appalachia and commit to preserving this rich heritage of racial harmony and diversity that years of legalized racism almost

\footnotetext{
${ }^{73}$ Wayne Winkler, Walking Toward the Sunset: The Melungeons of Appalachia, Macon, GA: Mercer Univesity Press, 2004, xi.
} 
annihilated from our history and memory. ${ }^{74}$

During these early years the site was text-heavy with only touches of color and an occasional photograph.

In September 2002, a special statement appeared on the site regarding the terrorist attacks of September 11 and the concern of the association that people of Middle Eastern heritage were being targeted for discrimination in the United States. For Melungeons, this must have felt like a replay of what they had suffered for so long. They said, "The Melungeon Heritage Association is living proof that America is a diverse nation: 'One people, all colors." ${ }^{\prime 75}$ In December 2002 the site was updated to show that Wayne Winkler had replaced Connie Clark as president and to list the CD transcriptions of many of the sessions at Fourth Union, the Melungeon Gathering that was held in June of 2002.

By August 2003, the site was significantly different. An annotated menu appeared on the left side of the screen that showed increasing complexity of the organization and its work. There was a joint statement from MHA and the Vardy Community Historical Society, a newsletter, a news-releases section, items for sale, as well as the familiar FAQs and list of Links. The site still used a white background, but the font style was changed to Arial, and the site had a more professional appearance.

\footnotetext{
${ }^{74}$ Melungeon Heritage Association [Website] (1999); available from http://web.archive.org/web/*/http://www.melungeon.org/; Internet; accessed 23 July 2005.

${ }^{75}$ "Special Statement Regarding the Terrorist Attacks on the United States of America from the Melungeon Heritage Association," Melungeon Heritage Association [Website] (September 26, 2001); available from http://web.archive.org/web/*/http://www.melungeon.org/; Internet; accessed 23 July 2005.
} 


\section{A NEW FACE}

In April 2004, the site had a dramatic make-over. ${ }^{76}$ According to webmaster Winkler, he chose to use a template provided by Business Information Systems in Piney Flats,

Tennessee. Shades of a rosy

brown and tan, appropriate for

a page about people who

suffered discrimination for

having coppery skin, contrast

with the crisp white of the right

hand space where text and

images can be displayed. A

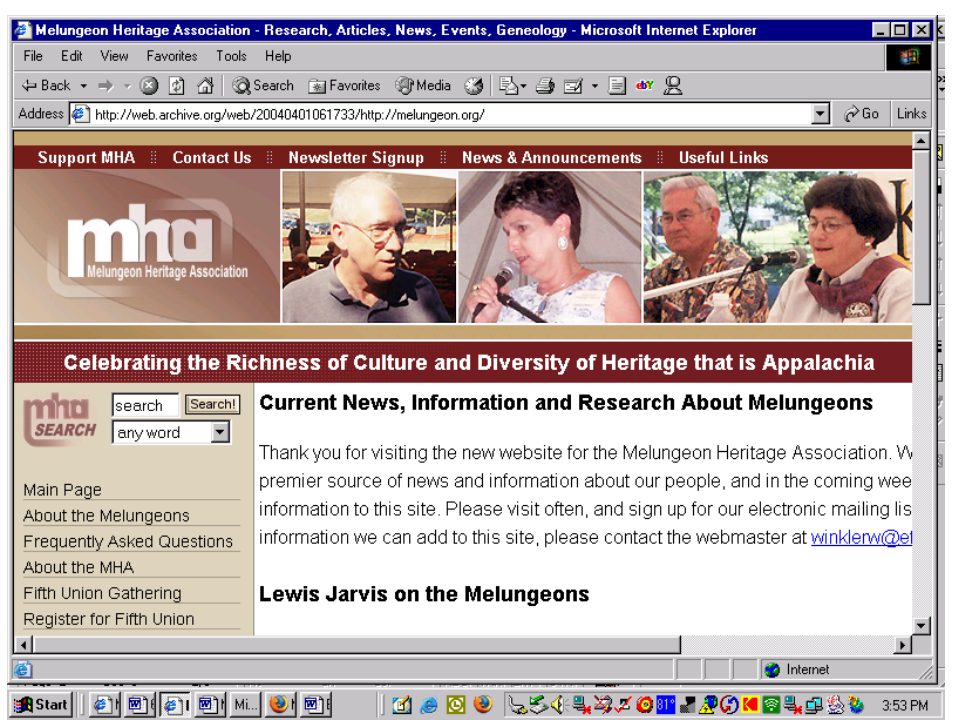

new MHA logo is prominently displayed in the upper left corner of every screen. The

photo images in the banner across the top of the page alternate; each time the user

accesses the page, the photos, which are a combination of pictures from recent MHA

events and archival photos from many years ago, may be different. This design is still in

place today.

There is one menu across the top of the screen that includes these choices:

"Support MHA," "Contact Us," "Newsletter Signup," "News \& Announcements," and

"Useful Links." Below the bar where the images appear is the MHA slogan: "Celebrating the Richness of Culture and the Diversity of Heritage That Is Appalachia.” Down the entire left margin of every screen in the site there is a menu that has certain titles that remain constant and others that expand (similar to drop-down menus) as the viewer

\footnotetext{
${ }^{76}$ It is interesting that the version of the page in the WayBackMachine archive has a picture of Katherine Vande Brake, non-Melungeon, shown as part of a panel discussion at Fourth Union, June, 2002.
} 
navigates to particular sections of the site. One of the most valuable sections is accessible from the left-hand menu; it is called "Tools for Research." These resources are either scholarly articles, very early texts from popular periodicals that are basics in Melungeon research (like the Dromgoole articles), or primary sources like letters, court documents, and laws. Of the total of 34 articles, 10 are the same as the "Historical Articles" on the Pezzullo site. The tone of Winkler's introduction to the list of articles, reproduced below, is more open-handed than Pezzullo's:

In this section, we are happy to present a collection of articles from various authors and sources which may shed some light on the "mystery" of the Melungeons. While we find these articles useful in research, the Melungeon Heritage Association does not necessarily endorse all the ideas and theories presented. Much of what has been written about the Melungeons over the years has been apocryphal or erroneous, but even the myths and mistakes are a part of the history of our people. We offer these articles and allow you to judge them on their own merits. A menu of available materials is on the left side of this screen. $^{77}$

This "Tools for Research" section of the site is text-heavy. However, the texts are very readable because they appear in the right two-thirds of the screen; the display size of the font can be adjusted by clicking on the "View" menu so that a reader can select the size she

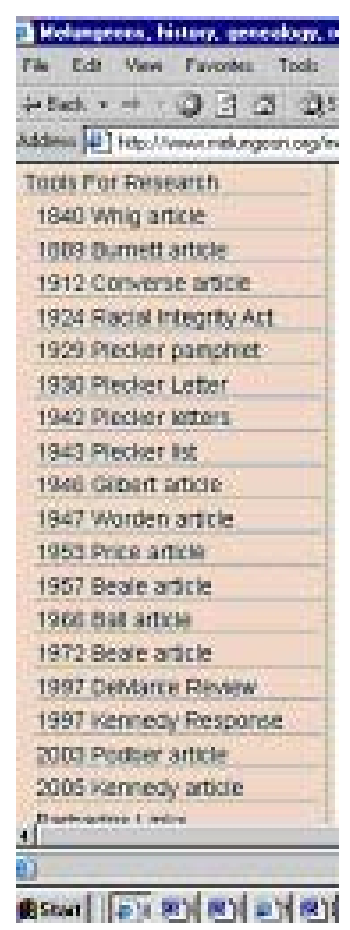

77 “Tools for Research," Melungeon Heritage Association [Website] (2005); available from http://www.melungeon.org/?BISKIT=2749209485\&CONTEXT=cat\&cat=100121; Internet; accessed 23 July 2005. 
prefers. Another section of the site called "Fifth Union Presentations" has the texts of some of the talks from the last major gathering held in 2004. The introduction to the list of presentations stresses one more time that the MHA works to educate the public and to encourage scholarly research; however, as Winkler has stated, they do not endorse every theory offered at their bi-annual unions or on their website.

\section{WAYNE WINKLER'S ETHOS AND M.H.A. IDEOLOGY}

Winkler emerges as a careful rhetor. He insists time and again, that opinions on many questions are varied. He addresses many of the issues current in Melungeon discourse on a page labeled "Frequently Asked Questions" and also in the lengthy essay that he prepared for his presentation at Fifth Union. His ethos is bolstered by his own documentable Melungeon heritage and his obvious eagerness for more information. He is more inclusive in his definition of who's included than Pezzullo. He addresses the second-class status that Melungeons had to live with and states that they have been identified by both phenotype and by family names. He addresses the "Ridge Only" theory promulgated on the Historical Melungeons site by noting: "Prior to 1900, the entire written record of Melungeons consisted of less than a dozen newspaper and magazine articles, nearly all focusing on the Hancock County group, and only a few individual Melungeons were identified in these articles. ${ }^{.78} \mathrm{He}$ then goes on to explain, "Researchers have identified several surnames as "Melungeon" names. ... If you find records of ancestors in these areas who have "Melungeon surnames," there is a strong possibility

\footnotetext{
78 “Some Basic Information," Melungeon Heritage Association [Website] (2005); available from http://www.melungeon.org/index.cgi?BISKIT=2404458932\&CONTEXT=cat\&cat=10076; Internet; accessed 24 July 2005.
} 
you have Melungeon ancestry - particularly if some family members are listed as nonwhite in census reports. ${ }^{.79}$

The MHA site is visually pleasing to me. The array of images that appear as the viewer moves from screen to screen keeps interest high. The consistency of every screen — same banner, same menu, same footer — keeps the user oriented. However, links do open in their own windows, a feature which takes users away from the MHA page and necessitates the use of the Back button to return to the links menu. Nevertheless, the MHA site's careful explanations and copious offerings of anecdote and theory make the site valuable for both serious researchers and casual visitors. A user can get a little information by clicking on "About the Melungeons" or investigate the many serious scholarly articles that have appeared in refereed journals from 1950 to the present. There is a professional and even-handed tone that invites the audience to learn more about the Melungeons or enables a viewer to navigate immediately to a particular previously published text.

Winkler and the MHA openly support Brent Kennedy. In fact the MHA began in Wise, Virginia, Kennedy's hometown. On the site there are reports about Kennedy that have appeared in various East Tennessee and Southwest Virginia newspapers as well as Kennedy's own pieces. On the site's splash page there is a link to Kennedy's Fifth Union presentation with addenda tacked on as he has received more DNA testing results, tests that he pursued privately and paid for with his own money, to confirm what he had long

\footnotetext{
79 "Some Basic Information," Melungeon Heritage Association [Website] (2005); available from http://www.melungeon.org/index.cgi?BISKIT=2404458932\&CONTEXT=cat\&cat=10076; Internet; accessed 24 July 2005.
} 
suspected about his genetic heritage. Kennedy is listed as an MHA board member in the "About the MHA" section.

\section{RHETORICAL INVENTION STRATEGIES OF THE M.H.A. SITE}

Winkler, trained as a journalist, uses many recognizable rhetorical invention strategies in his construction of the MHA website. He refuses to limit the scope of the site to just one issue, and weaves the pieces he has chosen together by writing introductions for the articles and artifacts and giving brief biographies of the authors. The fact that all screens are similar gives the site both unity and credibility. The goals of the MHA, articulated in their first effort to create a webpage, are also evident in this current version:

1) To set up a clearinghouse of Melungeon related information and an archive of Melungeon related materials.

2) To facilitate future Melungeon gatherings and events.

3) To make research information about the Melungeons and other similar groups available to the general public.

4) To become a central exchange registry for mixed-ancestry groups in the southern Appalachians whereby we can exchange relevant information and documents. ${ }^{80}$

Within the framework of both the mission statement and these goals, Winkler expands the concept of a "Melungeon" website to demonstrate both the uniqueness of the Melungeons and their connections to other mixed-ancestry people.

\footnotetext{
80 "Goals" Melungeon Heritage Association [Website]; (1999-2002); available at http://web.archive.org/web/20011218095141/www.geocities.com/BourbonStreet/Inn/1024/; Internet; accessed 24 July 2005.
} 
Winkler knows that the audience for his site is composed of casual web surfers, scholarly researchers, and those within the smaller Melungeon research community. The links section of the site has ties to a number of Melungeon sites (including Helen Campbell's melungeons.com but omitting Pezzullo's Historical Melungeons), two email discussion lists (Melungeon-L and the Melungeon Family Genealogy Forum), the Vardy Community Historical Society, as well as sites maintained by other mixed-ancestry groups. Winkler treats his audience with respect by maintaining a civil and even an inviting tone, by including writing that represents both sides of many issues and by situating the pieces he does offer with introductory paragraphs. Winkler's good will toward his audience is evident throughout the site.

Like the designers of the other two encyclopedic sites, Wayne Winkler cashes in on the high level of interest in Melungeon studies both within and without the Melungeon community. However, his view of the kairos is different. He sees the beginning of the modern era as the writing and production of the Melungeon outdoor drama Walk Toward the Sunset in the late 1960s. The Melungeon "Movement" received a powerful infusion of energy in 1994 when Brent Kennedy's book was published and again in 1997 after First Union. Since First Union, the Melungeon Heritage Association has kept the ball rolling by sponsoring bi-annual Unions and other one-day events in the off years. Geographically situated in East Tennessee, Winkler delights in trading on both his Melungeon heritage and his location in the heart of "Melungeon country."

Stasis is evident in both the arrangement of the MHA site and its tone. Winkler readily acknowledges in several places in texts he has authored on the site that there are many unresolved issues and unanswered questions. Thoroughly knowledgeable about 
ongoing research and cognizant of the discussions on several of the email discussion lists, Winkler is a calm voice in the midst of often-emotional dialog. He is comfortable with his decision to embrace many basic facts about the Melungeon people and to let disagreements swirl around him. The Melungeon Heritage Association invites rhetors from all quarters to present at their events, and they also expose the rank and file of the community to scholarly thinking pertaining to Melungeons in anthropology, communications, medicine, history, genealogy, literature, and the arts.

The only one of Aristotle's common topics that Winkler uses is the topic of possibility. Through his writings on the MHA website, Winkler allows that users of the information he provides, who are the audience for his rhetoric might choose to either agree or disagree with a presented point of view. His ideology is quite scholarly and seemingly dispassionate. Resting his case on the MHA mission statement and employing the usual conventions of journalistic and scholarly writing, he documents his assertions and refuses to assault the reader with emotional prose. His network of interpretation is broad enough that he can entertain many ideas without being threatened, and he does not need to make his position known on every minute detail.

The logos of the Melungeon Heritage Association site is calmer than either of the other two I have discussed. Its methodology is similar to the other two, however; true to Crowley and Hawhee's description modern rhetoric as inclined to use many examples, ${ }^{81}$ it includes many different texts to construct the knowledge that Winkler and the association of named individuals he represents deem important. The fact that he not only carefully builds his site but also painstakingly introduces the written pieces he includes

\footnotetext{
${ }^{81}$ Sharon Crowley and Debra Hawhee, Ancient Rhetorics, 156.
} 
helps create a reasoned approach to the "mystery" of the Melungeons. The difference between Winkler and Campbell is that he situates the pieces he includes, while she offers texts with no explanation. The MHA site is broadly inclusive in content and somewhat inclusive in ideology. If the site rests on an unstated enthymeme, it could be this:

Major premise: Melungeons are people who have been ignored in America's English-oriented history books.

Minor premise: Anthropological, historical, genealogical, and genetic research is shedding light on the mystery of the Melungeons.

Conclusion: Scholarly research available on our site may eventually solve the mysteries of the Melungeons and give them their rightful place in American history.

If this construction of enthymeme seems complex, it is because the Melungeon descendants and the struggles they have faced and continue to confront are also complex. Winkler and the Melungeon Heritage Association refuse to reduce the questions to just one or two over-simplified issues. DruAnna Overbay underscored the existence of this complexity in a recent email message:

It really surprises me that Wayne Winkler and Brent Kennedy have been able to maintain an academic stance in the heat of the various battles. But, even more surprising are the numbers of those who consider themselves Melungeon unwilling to accept others' concepts. It is a prism and some seem to be locked into a prison of one facet of that prism.... I think there is a difference among us about how our families migrated into the area during the $1700 \mathrm{~s}$ - prior to that time, many of us are open to speculation. Brent Kennedy opens that door for many. By 
the time we trace our ancestry back past 1700 there are so many tangled roots into various nationalities it is mind-boggling. All I know is from our oral tradition in Vardy. ${ }^{82}$

In this excerpt, Overbay acknowledges Winkler's (and Kennedy's) cool-headed approach, the intensity of debate on the various issues, and her own blind spots. She is not one who reads the websites or posts messages to the email discussion lists. Her Melungeon identity is not in question; she is a direct descendant of Vardemon Collins, one of the "original" Melungeons. She does not need to do any research to establish an ethnic identity or to validate her connections.

Pathos is very rarely evident in the fabric of this site. The only instance I noted that was deliberately inserted by the MHA was the statement about the September $11^{\text {th }}$ attacks on New York and Washington, D.C. Retaliation against American Muslims hit too close to home. Otherwise, the integrity of the site is dedicated to the principle of journalistic impartiality, which any student of rhetoric will recognize as fictional. In fact, Winkler does take a stand on the very issues that so strongly motivate Joanne Pezzullo and her mysteriously constituted Melungeon Research Committee. He says that Melungeon families were/are present in, not only Hancock County, but also Hawkins County, Tennessee, and Lee, Scott, and Wise Counties in Virginia. By openly supporting Brent Kennedy, the MHA endorses not just evidence in written documents, but also allows that DNA evidence, oral history, and informed speculation—such as some writings by Kennedy or Elizabeth Hirschman — may add important perspectives and lead

${ }^{82}$ DruAnna Overbay, email message to the author, 24 June 2005. 
to the solving of the mystery. So, although the MHA site "feels" more open, it does, in fact, inhabit a definite ideological position.

\section{A SEMIOTIC ASSESSMENT}

In semiotic terms, the Melungeon Heritage Association site, articulates a clear and thoughtfully consistent representation of Melungeon identity. In presenting many possibilities without an emotional overlay, Winkler demonstrates his understanding of the mission and goals of the MHA. This sign is professional, visually consistent, and radiates good will to all—even those persons who might disagree with its ideology. The site shows, by listing all the presenters at Fifth Union, that there is willingness on the part of the MHA to give every faction a voice. The site is clearly positioned in Melungeon discourse. The paradigm of the site is clearly visible in both the horizontal and the vertical menus; some of the vertical menu categories expand to longer lists as different parts of the site are accessed. Although Winkler employs no sound, his design utilizes the affordances of display competently by showcasing text and many still images in an easyto-understand arrangement. The MHA logo gets top billing in the upper left hand corner of every screen. The banner of photographs is appealing and might be rendered even more effective if the people depicted in the photos were identified (a transparent text box could be layered onto each image in a photo-editing software program). Many of the texts on the site contain hyperlinks to various parts of the site and to other web texts. In another recognition of the possibilities of publishing on the web, site users are able to contact the MHA either by sending an email message or by filling in a form that comes up under "Contact Us." 
Winkler shows that he understands the power of language by abiding by the grammatical and mechanical conventions of academic prose, yet his tone is not so formal as to be off-putting or patronizing. He gives both those who are accustomed to book conventions and those acclimatized to the Internet familiar ways of exploring the site's content. Images are important on this site, but text is still the main vehicle for the information and the ideology of the MHA he wants to communicate. The site is "a 'motivated' conjunction of form and meaning, produced out of the interest of the signmaker, whose 'use' of representational resources is agentive and transformative." Winkler has designed the site to present what he and the MHA consider to be relevant images of people who either illustrate the history of the Melungeons or show good times at the Unions, important texts in Melungeon research, and clear positions on the issues prevalent in Melungeon discourse.

\section{CHAPTER CONCLUSION}

At the beginning of this chapter about Melungeon websites I noted Gunther Kress's two questions from Literacy in the New Media Age. Answering them sums up the foci of the chapter. The first—“What is the future of literacy?" My answer- the future is unknown, but the now of literacy, for the Melungeon community, is a vital Internet presence. The second question- - What are the social and cultural effects of the emergence of the screen as the dominant medium?" An answer is that the websites analyzed here show that Melungeon descendants who are designers are making screens the primary medium for publishing their messages. Even though all the affordances of screens are not being fully

\footnotetext{
${ }^{83}$ Gunther Kress, Literacy, 169.
} 
utilized (no moving images, little use of sound or music), the sites show willingness to practice literacy in the very public forum of the World Wide Web.

Melungeon designers are choosing texts to post and to reference; Melungeon rhetors are presenting their arguments. Melungeon descendants and interested researchers are posting their thoughts in writing to the email discussion forums. The three encyclopedic Melungeon sites are signs that signify what it means to be Melungeon and show clearly the issues in their debates. 


\section{Chapter 7}

\section{Two Contemporary Melungeon Rhetors: Jack Goins and Brent Kennedy}

\section{CHAPTER INTRODUCTION}

Viewing the websites and monitoring the public archives of the email discussion lists quickly reveal that there are two rhetors who speak with authority and have large followings. Both have written a book, both have many texts available on the websites, both are considered leaders who speak for the Melungeon community. Goins is universally admired; Kennedy, though more prominent, gets mixed reviews.

\section{JACK GOINS}

Jack Goins was born in Kyles Ford, Tennessee, in Hancock County. He has been interested in genealogy from an early age when he heard stories from his grandfather about having Indian heritage. In his book Goins writes,

As a young teenager I was not very proud of the Indian heritage grandpa [sic] described that day, but later in life this knowledge of Indian ancestry was primarily the reason I began family research.....

Because of all the theories on the history of the Melungeons, I set out to find the answers from the source by discussing family history with descendants whose foreparents were considered Melungeon and who lived, or formally [sic- 
formerly?] lived in the surrounding areas of Kyles Ford, Blackwater, Newman ridge, and Sneedville. ${ }^{1}$

Goins not only interviewed people, he also dug through dusty documents in courthouses, tramped over hills and fields, and participated in DNA testing. His search for the truth about his own family and other Melungeon families in Hancock and Hawkins County has been relentless. Jack knows more specific data about more people than anyone I have ever met.

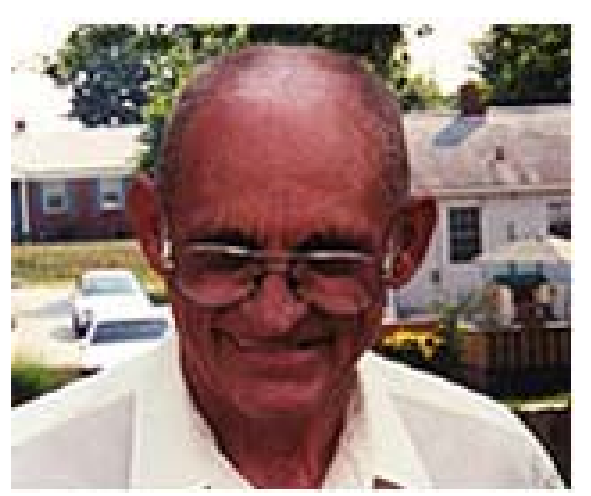

Melungeon Researcher, Jack Goins.

His bias is to favor documents. Goins believes that truth cannot be verified unless there is a written source to back up a claim. He feels strongly about this, but when there is a gap in the paper trail, even Jack Goins will speculate about what might have been or happened. One of the essays he has written, "Shepard 'Old Buck' Gibson,” demonstrates this tendency, an example of Aristotle's common topic of conjecture, or past/future fact. The section of the essay quoted here (with the conjecture italicized) speculates about the household arrangements of Matilda Gibson, Shepard Gibson's widow:

Now appears a 20-year-old Elizabeth Pugh living with the family as a hireling. . . . The Davis family mentioned above in district \#33 is now right next-door and the child Elizabeth Pue from the 1850 census is no longer in their household. The fact is, she is the twenty-year-old hireling in Matilda's house. We believe she is the daughter of John Davis, schoolteacher and granddaughter to Eli and Martha

\footnotetext{
${ }^{1}$ Jack Goins, Melungeons, 1-3.
} 
Davis. Most likely John's wife and Elizabeth Pue's mother, is deceased. Two avenues of thought concerning a possible connection between Matilda and the Davis family present themselves. First thought is Matilda may have been a Davis herself. Eli and Martha are old enough to be her parents and records show that John Davis was born in 1809 just a year before Matilda. This would explain one reason why Elizabeth Pugh ${ }^{2}$ is in Matilda's household. Matilda would have been her aunt. Matilda's Elizabeth and Elizabeth Pugh could have played together and Matilda may have taught both of the girls the art of tailoring and weaving. Matilda's son John D. could have been named for her brother John and the D. possibly stood for Davis. Martha (on the 1850 census) may be named for her grandmother Martha Davis. Secondly, the connection may be a romantic one. John Davis is a widower and Matilda a widow. Perhaps John taught Matilda's children at school. Perhaps John was the father of John D. and Martha [these are Matilda's last two children born after her husband Shepard Gibson had died]. The explanation for their names would remain but without the personal family tie to Matilda. Both of these ideas are only speculation. There is no documentation at this point to prove either idea. ${ }^{3}$

This long paragraph is a clear example of taking known documentable facts, the 1860 census data, adding known information about naming customs and coming up with not one but two possible stories about what might have been—an instance of past conjecture.

\footnotetext{
${ }^{2}$ The spelling of the surname varies in Goins's book. I doubt that he is misquoting the original documents. 3 Jack Goins, "Shepard 'Old Buck' Gibson," Historical Melungeons [Website]; (2005); available at http://www.geocities.com/ourmelungeons/buck.html; Internet; accessed 25 July 2005.
} 


\section{IDEOLOGY}

A sub-category of the common topics according to Crowley and Hawhee is the matter of a rhetor's ideology. Even though examples of conjecture and figurative language can be found in Goins's prose, he tends toward literalism and a strict interpretation of words on pages. A clear statement of his ideology is articulated in his 2004 essay on the Historical Melungeons site titled "Maybe Melungeon": "In my opinion the answer to who was a Melungeon lies with the family researcher working within the scope of the historical records. Those of us who search old records for the truth know proof of opinions come [sic] from documented research." ${ }^{4}$ Goins also believes that the "historical Melungeons" were the families that lived along Newman's Ridge and descended from Vardy Collins, Shepard Gibson, and Irish Jim Mullins. All of these families had the FPC designation on census records. In answer to the question "Which free persons of color were Melungeons?" Goins, relying on documents he has seen, writes "Eliza Haskell, William L. Worden, Henry Price, Sandra [sic] Keys [sic] Ivey, and many, many others too numerous to name, all had one thing in common - they wrote about and investigated the known historical Melungeons of the Blackwater/Newman Ridge area. Jesse Stuart [sic] Daughter of the Legend was indirectly pointing to these same interlocking families."

Goins's primary method of proof cannot properly be called invention, since he relies on the data he gets from documents; he relies instead on extrinsic proof. He swears absolute allegiance to the data of genealogy—court records, tax lists, deeds, birth certificates, death certificates, military records, and church records. He shows familiarity

\footnotetext{
${ }^{4}$ Jack Goins, "Maybe Melungeon," Historical Melungeons [Website]; (2005); available at http://www.geocities.com/ourmelungeons/maybe.html; Internet; accessed 25 July 2005.

${ }_{5}^{5}$ Jack Goins, "Maybe Melungeon," accessed 25 July 2005.
} 
with an array of secondary sources as well, but he qualifies his reliance on them by indicating that they might be true or that the writers must have had reasons for saying what they did, not that what they present is truth. First and foremost, Goins is a genealogist; he has, in fact, been designated as the Genealogist for Hawkins County, Tennessee, where he now resides.

\section{JACK GOINS’S DEFINITION OF “MELUNGEON”}

As previously noted, the sophistic topic of definition is a favorite invention strategy in Melungeon discourse. Jack Goins's lengthy "Definition of the Melungeons" appears on two of the three websites I have discussed, Historical Melungeons and the Melungeon Heritage Association site, and is highly regarded by all Melungeon researchers. ${ }^{6}$ Crowley and Hawhee list four different definition methods: definition by genus/species, enumerative definition, analytic definition, and etymological definition. ${ }^{7}$

Although many who write about Melungeons try to give an etymological review of the possibilities for the word, Goins skips etymology entirely. He begins with an analytic statement that includes all the following elements (according to Crowley and Hawhee in Ancient Rhetorics for Contemporary Students in an analytic definition no important item can omitted from a definition list): dark skin, a particular group of settlers, a time period (1790s), common acknowledgement of Portuguese descent, beginnings in Virginia, a list of surnames, a specific migration route, and an oral history that was eventually written down.

\footnotetext{
${ }^{6}$ When Goins' definition was first posted on Historical Melungeons in June 2003, Joanne Pezzullo, Helen Campbell, Brent Kennedy, and many others expressed their approbation and agreement on Melungeon-L.

${ }^{7}$ Sharon Crowley and Debra Hawhee, Ancient Rhetorics, 242-50.
} 
His analytic definition completed in the first paragraph, Goins then begins a very thorough review of texts that record the existence of the Melungeons in Tennessee. He quotes each text and then comments upon it. He supports his claims in a layered way, stressing the fact in each case that oral traditions came first and were subsequently written down. He ratifies his claim by quoting Saundra Keyes Ivey's doctoral dissertation. In compiling his definition, Goins references the piece in Littel's Living Age, Christopher Humble's article in the Home Mission Monthly, Edward Price's population study, the 1903 interview with Sneedville citizen Lewis Jarvis, and Swan Burnett's 1889 lecture to the American Anthropological Society. In addition, he cites evidence from census data, court records, and the statement by Wash Osborne that Bonnie Ball quotes in her book.

Goins's conclusion, which is the heart of his definition, is that the name Melungeon was unique to the Newman's Ridge area. Writes Goins, The bottom line is no one has come forward with a historical written record that they were called Melungeons in others [sic] places where they formerly lived before migrating to Hawkins County. Unless someone discovers an old document that will impeach the old witnesses named in this definition, we must except [sic - accept?] their statements as factual which [sic] was basically the word Melungeon was like a nickname placed on a certain group of people in a specific time and location. ${ }^{8}$

\footnotetext{
${ }^{8}$ Jack Goins, "Definition of the Melungeons," Melungeon Heritage Association; accessed 15 July 2005.
} 


\section{GOINS EXEMPLIFIES A POSITIVE ETHOS}

The rhetorical invention strategy that does emanate from Jack Goins's writing is development of a strong ethos. Goins is unassuming and accessible, yet he has great authority in the Melungeon community and is respected in larger genealogical circles as well. Goins is known for doing his homework. If he's wrong, he'll admit it; if there's new evidence, he wants to see it. In the Introduction to his book he writes, "The opinions expressed herein are my own and if there are mistakes I would appreciate folks pointing them out to me. ${ }^{\prime 9} \mathrm{He}$ is the only Melungeon researcher to have material on all three of the websites I discussed. Although he takes a definite stand on the necessity of documentary evidence, he is not dogmatic about that claim — he does allow for the importance of oral history in the Melungeon story.

Because Goins is so thorough and so knowledgeable — he knows so much about so many Melungeon families - even academics may forgive his lack of adherence to the conventions of scholarly writing. His vernacular veers toward mountain dialect, his punctuation and sentence structure are erratic, and his documentation style is not any recognizable standard format. Yet, his conclusions are based on painstaking research, and he knows exactly where he found every bit of information he references. He shows deep respect for his ancestors, other researchers, and his lay audience; in short, he usually radiates good will both in his writing and in person. One exception to this was an exchange in the arena of Melungeon-L in May and June of 2003, when Goins and Brent Kennedy disagreed about the DNA study by Kevin Jones that Kennedy had organized. Yet, even in that exchange, where the two were definitely polarized, there was

\footnotetext{
${ }^{9}$ Jack Goins, Melungeons and Other Pioneer Families, iv.
} 
communication and a clear articulation of their respective positions on DNA and other issues in Melungeon research.

\section{RHETORICAL ORNAMENT IN GOINS'S PROSE}

A final point about Goins's rhetoric is his use of stylistic and ornamental devices to embellish his prose. His book, as well as some of his email postings, is punctuated with great stories that he has uncovered in his research. Examples of enargia, the creation of vivid scenes, are not uncommon. One of the most memorable, quoted earlier in the chapter on "shared experience," is the story of Rebel Hollow, when a Confederate raiding party in January 1865 hanged the five men who left he Confederate Army to join the Union.

Another example both demonstrates the vitality of Goins's prose and shows a use of metaphor: "Some researchers have ignored both these old visitation accounts and cast them aside as to be taken as a grain of salt cast into the wind, or as [local?] color writers who should be ignored. My advice is to ignore any researcher who tells you this because every document must be carefully examined, because they are as scarce as hen's teeth."10

\section{A PICTURE TAKER}

Finally, I would liken Goins to a picture taker. He prefers the sharp sort of image, like a photograph, that emerges from looking at genealogical data. He is very much a modern rhetor, favoring factual proof over opinions as the final determiner of truth. However, his opinions about this and about many issues in Melungeon research place him in the

\footnotetext{
${ }^{10}$ Jack Goins, "Maybe Melungeon,” accessed 29 June 2005.
} 
rhetorical arena. His insistence on quite literal interpretations of documentary evidence is the primary commonplace in his network of interpretation. Like Pezzullo, he is not wont to see other positions as valid. As he says over and over, the family researcher must start with people he/she knows and work backwards to other blood relatives. He/she will encounter truth along the way.

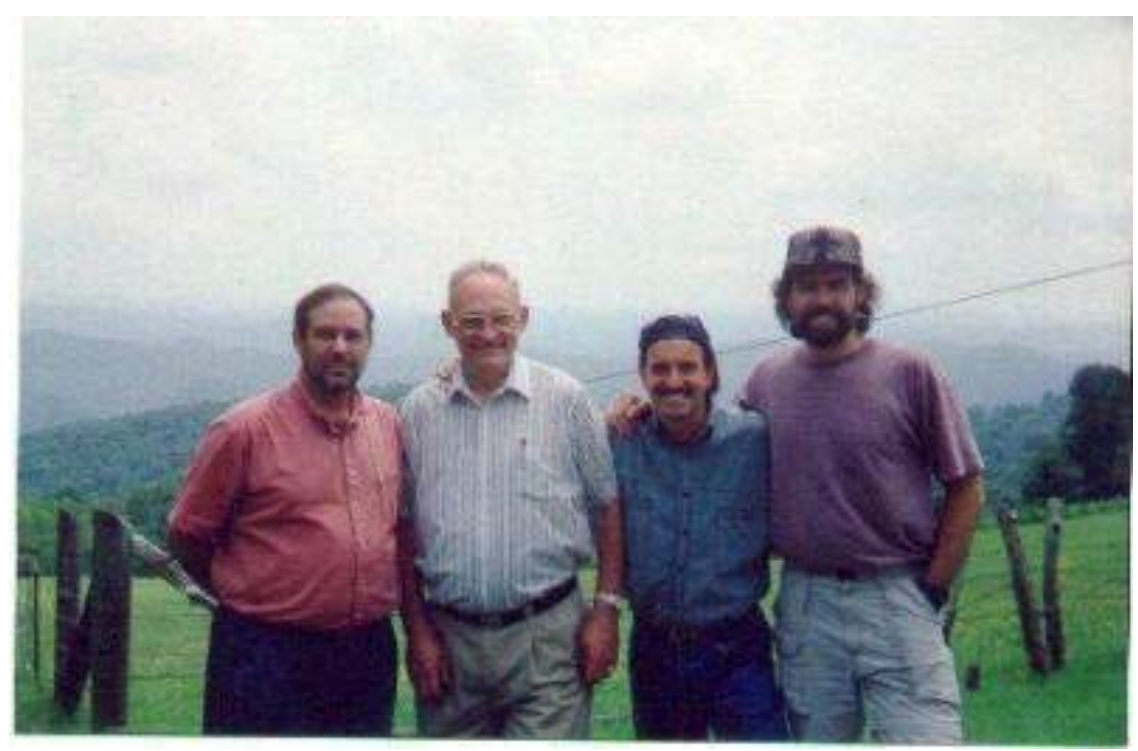

Scott Collins, Jack Goins, Brent Kennedy, and Bill Vanderkloot, in Hancock County, Tennessee, on a reconnaissance trip. Vanderkloot was hoping to make a documentary about the Melungeons. The film never materialized.

\section{BRENT KENNEDY}

N. Brent Kennedy, born in 1950 in Wise, Virginia, is the most visible spokesperson for the Melungeons. ${ }^{11}$ His 1994 book, Melungeons: Resurrection of a Proud People, really gave the Melungeons a visible place in the Appalachian landscape. Driven to find his family history by his near-fatal bout with sarcoidosis, Kennedy worked for six years in solitude before explaining and seeking to win adherents to his theories by publishing his book. What his detractors always seem to overlook is the simple fact that he never claimed to be an expert—not then, not now. In fact, he has insisted the opposite. "I

\footnotetext{
${ }^{11}$ Kennedy suffered two strokes in December 2005, one being severe. As of this writing, he has left acute care for a rehabilitation center. It is not clear whether his voice has been silenced. 28 January 2006.
} 
strongly emphasize," he wrote, "that I am not a historian, an anthropologist, or a professional writer. I continue to need - and energetically seek - the assistance of others. ... And while I feel strongly that my conclusions will indeed be born out by future scholars, I have been and remain open to any and all possibilities." ${ }^{.12}$ And he has remained open and refined his theories in the light of new information.

Kennedy, who has a Ph.D. in Communications from the University of Tennessee, is above all a great communicator. His book caused a stir not only among academics, who attacked him for shoddy scholarship, but also among Melungeon descendants as well as other lay persons in Appalachia. But, like it or not, when people want to know about the Melungeons, the person they call, the person they interview, the person they quote is Brent Kennedy. He can give an interviewer a thirty-second sound bite, a thirtyminute interview, or thirty hours of non-stop information. And, furthermore, he seems to sense what his interlocutors want. Handsome, well dressed, well spoken, and knowledgeable, his book made him the spokesperson and he has continued to be that. These very qualities that make him valuable to the "Melungeon Movement," may be the source of jealousy for others like Jack Goins or Jim Callahan. I asked DruAnna Overbay and Wayne Winkler what they saw to be the source of the strong animosity against Brent Kennedy that comes out both on the email lists and on some of the websites; they said they thought that jealousy was the primary cause.

Kennedy stated in an article published online in Under One Sky: The Melungeon Information Exchange that his original intent "to attract—and force if necessaryscholarly and public attention to the story of the Melungeons and other mixed-race

\footnotetext{
${ }^{12}$ N. Brent Kennedy with R.V. Kennedy, The Melungeons, viii.
} 
people of this Nation," ${ }^{, 13}$ has never wavered. All his speaking and published articles from then to the present really bear out this stated goal. In his book he said that he based his theory on six conditions that he listed in order of priority: ${ }^{14}$

1) Assumed Melungeons were telling the truth about Portuguese ancestry (and possibly Spanish ancestry)

2) Assumed Melungeons had arrived mid- to late-1550s and learned to speak English from English settlers/explorers

3) Assumed that English was their second language because it was not standard

4) Assumed that the original group (by backtracking and assuming four surviving children per couple) could have been 200 people including both men and women.

5) Given the surviving Mediterranean physical characteristics in Melungeon descendants, assumed that both genders of the original group must have possessed "Melungeon" genes

6) Assumed that the word "Melungeon" originated with the people themselves and that they only came to resent it after it was used in a derogatory way against them.

Kennedy's theory, which he offered as a hypothesis never claiming it to be the absolute truth, is an example of past conjecture. The story of the Siddi girl already quoted

\footnotetext{
${ }^{13}$ Brent Kennedy, "Kennedy Announces New Focus in Personal Mission," Under One Sky: The Melungeon Information Exchange 3:1 (1998) on Darlene Wilson's Melungeon Website, now defunct.

${ }^{14}$ N. Brent Kennedy with R.V. Kennedy, The Melungeons, 103-4.
} 
in an earlier chapter, excerpted from Kennedy's remarks at Fourth Union, is an extension of his previous ideas, not a new theory.

Kennedy's version of the story of Melungeon origins begins in 711C.E. when the Moors, consisting of both Arabs and Berbers, moved into Spain. By 1200 many of these transplanted North African people at least outwardly converted to Christianity, practicing their religious (Jewish or Muslim) and other cultural traditions in the privacy of their homes. When the Inquisition descended on the Iberian Peninsula, these conversos escaped any way they could to France, to England, to the Canary Islands, to North Africa, and to North America. Once in the New World they began to fan out from the Spanish settlements including Santa Elena and Explorer/Captain Juan Pardo's forts and to intermarry with Native Americans and later with free Africans and escaped slaves.

An addendum and a second interesting example of past conjecture is the story he pieced together from Sir Francis Drake's journals and other old records about Drake's abandoning of a number of Turks at the Roanoke colony so the colonists could board his ships and return to England in the late 1580s, a time of great turmoil between England and Spain. Though these Turks were told that a ship would come back for them, instead of waiting around, they vanished into the interior and could have been, according to Kennedy, some of the ancestors of the Melungeons. Most Americans are ignorant of this story because, as Kennedy often says, the winners write the history.

Kennedy is the master of the "Tale," which Crowley and Hawhee define as "retelling stories from history and poetry" using narrative. ${ }^{15}$ Ancient teachers encouraged practicing students to retell their stories starting in different places and to add touches of

\footnotetext{
${ }^{15}$ Sharon Crowley and Debra Hawhee, Ancient Rhetorics, 389.
} 
description and characterization. Kennedy does all these things in his retellings of how he thinks the dark "mysterious" Melungeons got to Appalachia. Kennedy, like Goins, does genealogical research, but he also sees a bigger picture. He wonders not just how his ancestors got from Eastern Virginia or Western North Carolina to Appalachia but also how the off-shore others arrived in the first place. On July 9, 2005, Kennedy posted additional DNA information from not only himself and his brother but also from two of his mother's aunts, one each from her father's and her mother's families. All of this DNA information shows that he was right about many things from the outset and that his detractors, particularly Virginia DeMarce, were wrong. Kennedy insisted all along that his physical characteristics, certain medical conditions he has, and his DNA results (before he even knew them entirely) would prove that the oral tradition in his family was right and that the paper trail stating he was Scots-Irish was wrong. He has lived to see his suppositions borne out.

In December 2002, after Fourth Union, when the Joanne Pezzullo had just put up the Historical Melungeons site, Kennedy wrote an essay that was published as the feature of the month on melungeons.com. In the essay he defined his terms once again and tried to answer his detractors. He distinguished between four groups; members of all four were a part of the Melungeon Movement and were attending the Unions and benefiting from the ongoing genealogical and scholarly research. First, he defined historical or "original" Melungeons as "those documented by the pre-1900s written record." ${ }^{\text {"16 }}$ Different from Goins and Pezzullo, he includes Melungeons in Lee, Scott, Dickenson, and Wise Counties in Virginia as well as the Blackwater/Vardy/Newman's Ridge group in

\footnotetext{
${ }^{16}$ Brent Kennedy, "Statement from Brent Kennedy 12-03-02" The Melungeons (melungeons.com). Website. 2002-2005. Available from http://www.melungeons.com. Internet;. Accessed 25 June 2005.
} 
Tennessee under this rubric. A second category is "Descendants and Relatives of Historical Melungeons - those who are descended from or documentably related to, the Blackwater/Vardy/Newman's Ridge group and/or the southwest Virginia group wherever they may have migrated." ${ }^{17}$ His third category he calls "Melungeon Related," which he defines as "those populations scattered around the southeast (as far south as Graysville, Tennessee and north into Indiana and Ohio) which likely share the same general genetics, at least some family lines, and have cultural overlap.... not, however, 'Melungeon' in the strictest traditional sense." ${ }^{, 18}$ And, finally, a fourth category, he identifies as "Mestee groups," which are also mixed race and share many of the same historical and cultural experiences but are not necessarily Melungeon or Melungeon-related."19 Jack Goins and Joanne Pezzullo and presumably others on their Melungeon Research Committee do not agree with these definitions.

\section{KENNEDY, A CLASSICAL-STYLE RHETOR}

Kennedy is in many respects a classical rhetor. He is largely responsible for the kairos that makes Melungeon studies a vital site for research and discussion. His challenge has provoked scholars in genealogy, history, anthropology, medicine, communications, and literature to do serious research and to give serious thought to Melungeon people. The Unions as well as refereed journals, the popular press, and, of course, the Internet have provided the stage upon which the Melungeon drama is playing out.

\footnotetext{
${ }^{17}$ Brent Kennedy, "Statement from Brent Kennedy 12-03-02" The Melungeons (melungeons.com). [Website]; (2002-2005); available from http://www.melungeons.com. Internet; accessed 25 June 2005.

${ }^{18}$ Brent Kennedy, "Statement from Brent Kennedy 12-03-02" The Melungeons (melungeons.com). [Website]; (2002-2005); available from http://www.melungeons.com. Internet; accessed 25 June 2005. ${ }^{19}$ Brent Kennedy, "Statement from Brent Kennedy 12-03-02" The Melungeons (melungeons.com). [Website]; (2002-2005); available from http://www.melungeons.com. Internet; accessed 25 June 2005.
} 
Kennedy himself, even though his opinions are strongly and consistently held, is at a point of stasis with his opponents and detractors. The long email discussion in MayJune 2003, with Jack Goins in the public forum of Melungeon-L, demonstrated the fact that the two are far apart on many basic issues. Kennedy thinks more broadly and is not as tied to literal interpretation of documents. The documents in his own family carefully hid the truth of his origins; this led him to learn to read between the lines, to know when to ask one of his relatives a probing question, and to listen carefully to the family stories that no one ever wrote down. Kennedy allowed in that exchange that he and Goins will never agree and that their disagreement should neither get in the way of friendship nor prohibit mutual respect.

As already stated, Kennedy is a master at the common topic of conjecture. True to the rhetorical tradition, he is at his best when he speaks. I have heard him many times and listened as he wove stories together (a contemporary enactment of the canon of memory) in a different way for each audience he addressed. In spite of the differences in various speeches and pieces of writing, he never wavers from his ideology. In the December 2002 written piece for melungeons.com, he addresses the matter of documentation, one precise issue over which he and his detractors disagree:

"Documentation" is absolutely essential but documentation alone cannot tell the whole story. The written documents are only as accurate—and honest—as the people writing them. W.A. Plecker proved that even in this century documents can be politically — and legally — created to say or "prove" anything. But this does not mean that we ignore the records and toss them out. On the contrary, the written record is one of the most vital pieces of the story. My concern has never 
been with the genealogical records, but instead [with] our blind acceptance of them as indisputable proof of ethnicity. ... I did NOT overlook the records and I do NOT question well-researched, documented genealogical records. But I do sometimes question the accuracy of what those records say, especially in a colonial, racist society in which "people of color" or of the "wrong" religious bent were doing all they could to be "English" or "Scots-Irish." 20

It would seem that such a statement would explain his position and quiet the furor, but ill will has persisted.

Kennedy uses rhetorical reasoning in his prose. Because his thinking is complex, it is difficult to isolate simple enthymemes that drive his thought. Many of his premises go back to the assumptions he stated in his book. Of late, because of several years of submitting to DNA testing, some of his speaking and writing focuses on scientific demonstration. He keeps on saying that the genetic evidence had to come from somewhere; his own results for EuroDNA show 45\% Northern European, 25\% Middle Eastern, 25\% Eastern European (Turkish-Greek/Mediterranean), and 5\% South Asian (India-Pakistan). These results bear out what his body told him all along. My ridiculously simplified statement of an enthymeme that drove his thinking, speaking, and writing even before the DNA results, is below:

Major Premise: Many Melungeons look “Mediterranean” (Arabic, Jewish). Minor Premise: I look Mediterranean.

Conclusion: I might be Melungeon (in spite of what the records say).

\footnotetext{
${ }^{20}$ Brent Kennedy, "Statement from Brent Kennedy 12-03-02" The Melungeons (melungeons.com) [Website]; (2002-2005). Available from http://www.melungeons.com. Internet; accessed 25 June 2005.
} 
My statement is very simplistic, but, nonetheless, Kennedy has been adamant that physical characteristics that he shared with his mother and brother and the facts of his several medical conditions—-sarcoidosis, Familial Mediterranean Fever, and lactose intolerance - were signs in his body that could not be ignored in his search for the truth of his origins despite the "facts" of the documents in official repositories in Southwest Virginia. Kennedy's well-structured arguments on behalf of his views of the Melungeon situation demonstrate a logos unrivaled in the Melungeon community. Whether or not he ever formally studied rhetoric, he is a master in its use.

\section{A CREDIBLE ETHOS}

Although there are people who disagree with me, I find Kennedy's ethos credible. He is

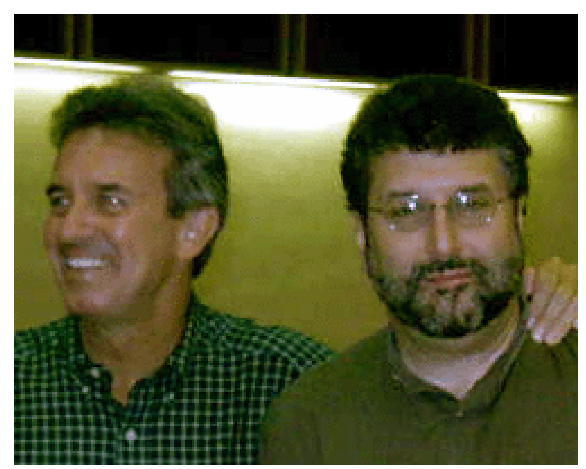

Brent on the left and his brother, Richard, on the right. This picture taken at Fifth Union.

winsome, aware of — though not persuaded by_opposing points of view, and articulate.

He demonstrates good will in person and in the email forums, even though he is often attacked. He consistently talks of his respect for scholarly work whether he supports the scholars' conclusions or not. He is a dynamic speaker and delights in telling his Melungeon story. He should not be vilified because he is charismatic. His work and his speaking and writing have brought attention to the Melungeons and to their cause and encouragement to many researchers. $^{21}$

\footnotetext{
${ }^{21}$ I will never forget the letter I received from him in 2000 that told me he thought my work in analyzing the fiction with Melungeon characters was outstanding and that he was recommending that Mercer University Press accept my book for publication.
} 


\section{INVENTION STRATEGIES}

Like any competent classical rhetor, Kennedy will use pathos when he thinks it's appropriate. Some of the passages about particular family members in his book, such as the material about his grandmother Rexie Nash Hopkins, who was murdered by her husband in front of their two children, have palpable emotional content. He has a way of telling his story and the stories of his ancestors that resonate for his readers/listeners. Elizabeth Hirschman's testimony is typical:

I wandered into a bookshop [in the Atlanta airport] where I saw a book entitled The Melungeons: Resurrection of a Proud People by N. Brent Kennedy. . . . When I glanced at the pictures in Brent Kennedy's book and looked over the genealogies he had included, I realized I was seeing myself, my heritage, my ancestors, and my history. Indeed Brent and I turned out to be third cousins. . . It is difficult to verbalize how stunning a revelation this was to me personally. ${ }^{22}$ Kennedy's use of enargia makes his stories all the more vivid and engaging. He makes the factual genealogical data come alive by adding details to flesh out what might have been.

As I noted earlier, Kennedy respects facts, but he is rhetorical in his use of them, weaving arguments to persuade his hearers rather than relying on the names and dates alone. He appeals to the work of scholars in many disciplines to ground his own thinking and, furthermore, is skeptical of every conclusion he might find. He judges a person's work by how it fits into the broader picture of the knowledge that a broad-based scholarly community is slowly building about mixed-ancestry people in North America in general

\footnotetext{
${ }^{22}$ Elizabeth Hirschman, The Last Lost Tribe in America, ix.
} 
and the Melungeons in particular. His position is that no discipline should be blind to the broader picture or rigid in applying its presuppositions. He claims that his own story is proof that the written record must be carefully scrutinized. Kennedy is able to draw on the sophistic topics of definition, division, classification, and similarity when he needs them to make an argument. Like the classical rhetors of old, his ongoing study of everything he can gather that relates to his interests deposits bits of information in his memory, which he draws on in the arena of public debate.

\section{A PICTURE MAKER}

In summary, I would liken Kennedy as rhetor to a "picture maker," perchance an Impressionist, making an image from many points of light and color. He does not demand photographic clarity in his images but is pleased instead with a representation of the truth that combines many facts and ideas into a coherent whole.

\section{KENNEDY AND GOINS IN CONTRAST}

Brent Kennedy and Jack Goins represent two significant positions within the Melungeon community. Crowley and Hawhee note that opinions take on great importance in communities, for "[i]f a significant number of individuals within a community share an opinion, it becomes difficult to dismiss that opinion as unimportant, no matter how much we like or detest it." 23 This is why the stakes are so high; many people do not yet know what they think about the origins of the Melungeons or what counts as evidence in the debates. The Melungeon community is both viewing and participating in a lively debate

\footnotetext{
${ }^{23}$ Sharon Crowley and Debra Hawhee, Ancient Rhetorics, 24.
} 
primarily on the Internet to determine the answers to their persistent questions. Their literacy that has become usual for them only in the last century is being put to the test as they search for their origins and try to understand their history.

Goins and Kennedy share some common ground, but they do not agree on many points within the rhetorical situation they share. Rhetorician Wayne Brockriede suggests that there are three dimensions in any rhetorical situation —interpersonal, attitudinal, and situational. ${ }^{24}$ The first has to do with how well the two people involved like each other. Does the photograph of Goins and Kennedy demonstrate that they like each other? For a fact, they do know each other, and Kennedy, editor of the Melungeon series of books at Mercer University Press, is encouraging Goins to submit his book manuscript for consideration instead of self-publishing it as he did the first time it appeared.

The second dimension is a power dynamic and has to do with how much personal influence a rhetor has. According to Crowley and Hawhee, power may come from charisma, control over channels of communication, influence, or access to other powerful people. ${ }^{25}$ This list very nearly restates Jim Callahan's list of complaints. Kennedy is in a position of considerable power; he is the voice of the Melungeons. Others may rant and rave on the websites or in the forums, but Kennedy is the one who is sought out and quoted by major media outlets - the Melungeon newsmaker.

Brockriede's third dimension is situational and has to do with social distance. This, too, is a factor. Kennedy is solidly middle class, bolstered by his jobs in a communications firm, as a university administrator, and currently as a hospital administrator. Goins is retired from a career at AFG Industries near Kingsport,

\footnotetext{
${ }^{24}$ Sharon Crowley and Debra Hawhee, Ancient Rhetorics, 196-7.

${ }^{25}$ Sharon Crowley and Debra Hawhee, Ancient Rhetorics, 197.
} 
Tennessee, and serves as Genealogist for Hawkins County. The playing field between the two is not level. In light of these factors, Goins's prominence in Melungeon research is nothing short of astounding. 


\section{Chapter 8}

\section{It Was a Wired Neighborhood: One Discussion Thread on Melungeon-L}

\section{CHAPTER INTRODUCTION}

One of the most interesting literacy practices among Melungeon descendants is their participation in listserv discussions. In 2002, I undertook a study of one thread of discussion on Melungeon-L, a genealogy discussion list at the Rootsweb genealogy site. This chapter will report my findings and also comment on this literacy practice. The gradual emergence of the Melungeons into the mainstream of both Appalachian and American culture has meant that owning up to Melungeon heritage is no longer bringing the same degree of social stigma it once did. Whether the more tolerant ideas stem from the civil rights movem; from a growing awareness brought about by Ball's and Bible's books coupled with the outdoor drama, Walk Toward the Sunset; from Brent Kennedy's book; or from the acceptance of a post-modern multi-cultural attitude, the change is clearly evident, and the email discussion list was in 2002 a clear manifestation of a new interest in exploring Melungeon ethnicity and finding historical and genealogical truth for the group and for individuals within the group.

Many themes already identified in previous chapters were playing out in various ways on the list. And, I found that, contrary to my original and somewhat naïve expectations, there was a tendency for list members to practice exclusion in reverse. To 
be a member of the "in-crowd" was to define others as non-members of that small group. I initially thought the list was a place for learning and sharing information. My analysis showed me that Melungeon-L was a social space with all the intricacies, dysfunctionalities, and power struggles of any group setting — a space that demanded careful negotiation.

One noteworthy aspect of the email-list community practices is that both literacy and images are a part of the semiotic act of making meaning that occurs every time a list member posts or reads a message. The sign articulator uses her keyboard to type letters that form words; the words comprise a text. The text is an image on a computer screen that must be read by an interpreter, who has the choice simply to receive the text or to respond to its meaning by composing and sending another message.

\section{HISTORY OF MELUNGEON-L}

Mary Goodyear, a native of Shauk, Ohio, whose interest in Melungeons was initially genealogical, started the list in 1996. Her first encounter with the Melungeon story was reading Brent Kennedy's book, but that wasn't enough; she wanted more information. Her difficulty in finding out about the Melungeons, whom she thought might be counted among her ancestors, led to her founding the list, which proved to be very popular and served not only as a genealogical resource but also as a place to share history and folklore. By the time of First Union in 1997, there could be as many as 650 messages over weekends, the times that the list was most active. When Wayne Winkler interviewed Goodyear in 1997, she claimed she was the person who had proposed First Union; she thought bringing the list members together face-to-face would be a richly informative 
experience and would also feel like a family gathering since list members were "almost like a family." "So, early on, the list was social, "almost like family."

At the time of my analysis of the "Melungeon herbal medicines" discussion thread in January/February 2002, the list was averaging 1113 messages per month. Conversation was lively and many threads were usually in progress at the same time. However, disruptions occurred in 2003 and in 2004. There were sharp drops in the number of messages and familiar email addresses stopped occurring. After August 2004, the volume of messages never bounced back, with the lowest number so far being 39 in March 2005. The issues that I outlined in the website chapter-who can be included and what counts as evidence — proved to be too volatile for the list

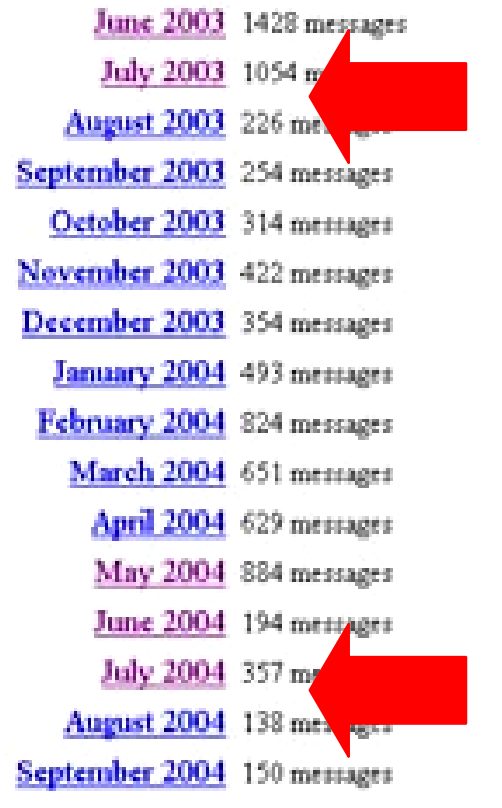
members to tolerate in a single forum. I know of seven different email discussion lists: Melungeon-L, Melungeon Family Genealogy Forum, Melungeon Kin-L, MelungeonChristians@smartgroups.com, Melungeon DNA-L, Historical Melungeons, and melungeons@topica.com; and there may be more. Many of the "regulars" have left for other lists, and the parent of them all, Melungeon-L, averaged only 87 messages per month from January to June 2005. In this chapter, I will present my analysis of the "Melungeon herbal medicines" thread and then discuss what I see to be the reasons for the disintegration of the community as I observed it early in 2002 .

\footnotetext{
${ }^{1}$ Mary Goodyear, Interview with Wayne Winkler, July 1997.
} 


\section{CMD—COMPUTER-MEDIATED DISCOURSE}

According to Susan Herring, computer-mediated discourse "is the communication produced when human beings interact with one another by transmitting messages via networked computers. . distinguished by its focus on language and language use in computer networked environments, and by its use of methods of discourse analysis to address that focus. ${ }^{2}$

Melungeon-L@rootsweb.com, an instantiation of computer-mediated conversation, is further defined by the following characteristics:

- It is a private forum with limited membership, although anyone can subscribe.

- There is a moderator who steps in occasionally to enforce rules.

- The rules and guidelines for participation are emailed when a person joins the list. The moderator can unsubscribe list members for infractions.

- Conversation occurs in a non-work related setting.

- It was very interactive in 2002 when the study was done.

- It is a listserv with email addresses visible.

- Communication is through language or occasionally by means of ASCI characters fashioned into images; all auditory or gesture content that a message writer wants to convey must be done with keyboard characters.

- Communication is asynchronous, sometimes one individual to another individual, but most often one individual to many, the list members.

\footnotetext{
${ }^{2}$ Susan Herring, "Computer-mediated Discourse," in The Handbook of Discourse Analysis, eds. Deborah Schiffrin, Deborah Tannen, and Heidi E. Hamilton (Malden, MA: Blackwell Publishers, 2001), 612.
} 
Communication on the list is framed within the particular context of a social situation. ${ }^{3}$ The language used helps shape the social situation and, in turn, is shaped by it; there is a tension here between these two sides of language use, the socially shaped and the socially constitutive. ${ }^{4}$ The list members come to the list with the backgrounds of their social setting, their personalities, their educations, and their ideologies. Their participation is a factor in constituting altered social identities, social relations, and systems of knowledge and belief. The list participants do bring shared knowledge; my attempt to codify this knowledge is represented by the items listed in the table below that relate to the thread's topic, the general list topic of Melungeon research, and the computer skill set needed to be a list participant.

Table 1: Shared Knowledge and Skills Appalachian regional understandings

- Some knowledge of herbal/home remedies

- Effect of isolation of mountain communities

- Expectation of treating illnesses at home

- Making and having access to moonshine

- Familiarity with snake handling churches

- The Wendie Bagwell story

- Southern Gospel Music

What Melungeon means to a list member

- Possibilities for origins are known and understood but not all accepted (Native American, Mediterranean, African-American)

- Families lived in Southwest Virginia, Upper East Tennessee, and Eastern Kentucky

- A shared history of enduring prejudice and persecution

- Certain physical characteristics are prevalent including dispositions to particular illnesses

- Certain surnames appear in ancestral lineages

- Genealogical research can be difficult because so many records were destroyed by fire and/or by stealth

- Familiarity, but not agreement, with many books and articles about Melungeons

- $\quad$ Respect for people who can, without dispute, prove Melungeon heritage

Some level of computer expertise

- $\quad$ Facility with an email client

- $\quad$ Ability to copy and paste

- Knowledge of how to search for information on the internet and how to use a URL

\footnotetext{
${ }^{3}$ Norman Fairclough, Discourse and Social Change, (London: Polity Press, 1992), 231.

${ }^{4}$ Norman Fairclough, Media Discourse, (London: Edward Arnold, 1995), 55.
} 


\section{DESCRIPTION OF THIS STUDY}

Here is a summary of the facts about the "Melungeon herbal medicines" thread.

Table 2: Statistics about the "Melungeon herbal medicines" Thread

\begin{tabular}{|l|c|}
\hline Total number of posts in this thread & 80 \\
\hline Dates & $1 / 31 / 02-2 / 8 / 02$ \\
\hline Total posts to list during this period & 368 \\
\hline Total number of list subscribers & 320 \\
\hline Number of participants in this thread & 33 \\
\hline Number of subject headings in thread & 18 \\
\hline Average number intonation units & 7.44 \\
\hline
\end{tabular}

The table shows that just over $10 \%$ of the total number of subscribers participated in the thread under discussion and that the thread was about $22 \%$ of the total number of posts during the nine days duration. There are three groups of people to recognize in this study. The first group is all list subscribers, about 320 at the time of this discussion. ${ }^{5}$ The second group is list contributors, those who participate in some discussions. The third group is Melungeons who can document their heritage.

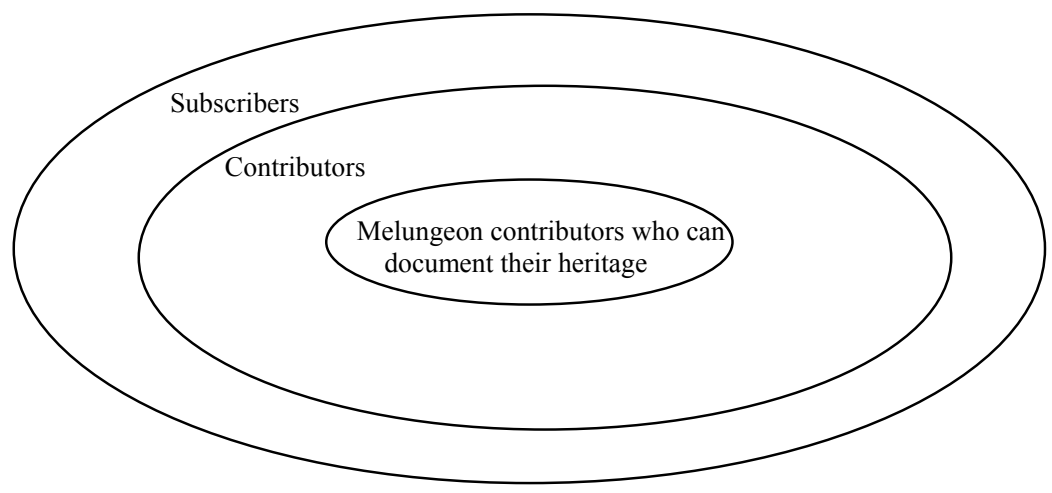

Many list members have Appalachian roots but are actually from various parts of the country. I have been an intermittent subscriber since 1999 and have seen many postings indicating that list contributors live all over the United States: West Virginia, Kentucky, Michigan, Texas, California, Pennsylvania, in addition to the expected locations of

\footnotetext{
${ }^{5}$ Dennis Maggard, List Owner. Email to author. 15 March 2002.
} 
Virginia, Tennessee, and Kentucky. Postings to the "Melungeon herbal medicine" thread can be broken down in these two ways, first by gender, and second by number of postings made by participants.

Table 3: Participants and Postings by Gender

\begin{tabular}{|c|c|c|}
\hline Gender & Participants & Number of Postings \\
\hline Female & 19 & 41 \\
\hline Male & 9 & 31 \\
\hline Can't determine & 5 & 8 \\
\hline
\end{tabular}

Table 4: Postings per Participant
\begin{tabular}{|c|c|}
\hline $\begin{array}{c}\text { Number of } \\
\text { Participants }\end{array}$ & $\begin{array}{c}\text { Number of } \\
\text { Postings per } \\
\text { Person }\end{array}$ \\
\hline 1 & 9 \\
\hline 1 & 8 \\
\hline 1 & 7 \\
\hline 2 & 5 \\
\hline 2 & 4 \\
\hline 4 & 3 \\
\hline 5 & 2 \\
\hline 16 & 1 \\
\hline
\end{tabular}

\section{MESSAGE GENRES WITHIN THE DISCOURSE OF MELUNGEON-L}

Michel Foucault was the first theorist to write about discourse communities. Norman

Fairclough also discusses how communities use language; he terms a community's use of language its "order of discourse." According to Fairclough, the "order of discourse" includes all the discursive types that are used in the community's interaction. On Melungeon-L, different discursive types would include genealogical queries/answers, folklore, history, literary/media criticism, and personal conversation among others.

Fairclough distinguishes between discourses (the language used in representing a given social practice from a particular point of view) and genres (uses of language associated

\footnotetext{
${ }^{6}$ Norman Fairclough, Media Discourse, 55.
} 
with and constituting part of some particular social practice). ${ }^{7}$ Discourse is the larger category, genre, the smaller.

A number of genres, which could occur both in written and spoken communication, are apparent in the "Melungeon herbal medicines" thread.

Table 5: Genres

\begin{tabular}{|l|c|}
\hline \multicolumn{1}{|c|}{ Genres found in thread messages } & Instantiations \\
\hline Comments on or a direct response to a previous message & 30 \\
\hline A narrative - story or anecdote & 23 \\
\hline A previously unmentioned home remedy offered & 15 \\
\hline Information (historical, scientific, theological) & 11 \\
\hline Memoirs of having one or more remedies administered & 11 \\
\hline Questions & 8 \\
\hline Reverie or nostalgia for days gone by & 3 \\
\hline Jokes & 3 \\
\hline Lament for dead friend (Jack Goins of Washington state) & 3 \\
\hline "Baiting" or picking at the list & 1 \\
\hline Apology & 1 \\
\hline
\end{tabular}

Certain evident features of the texts are unique to the email format and the properties of computer-mediated communication. The first is the built-in ability to "reply" to a message and have the text of the sender's message reproduced in the new message. When a writer hits "reply," she has the option of writing her message either above or below the sender's text, or she can intersperse her words inside the sender's text. The second is the "copy and paste" capability. The third is the sharing of URLs with the expectations that the address will link the recipient of the message to the indicated website.

Table 6: Electronic Mail Features

\begin{tabular}{|l|c|}
\hline \multicolumn{1}{|c|}{ Genre particular to electronic mail } & Instantiations \\
\hline Previous message copied $100 \%$ & 34 \\
\hline $\begin{array}{l}\text { Pertinent part of previous message copied and pasted into } \\
\text { a new message }\end{array}$ & 9 \\
\hline URLs shared as part of all of message & 2 \\
\hline
\end{tabular}

The shapes of messages on the screen are influenced by both of the considerations outlined above - the language used in the context of a certain social practice and email

\footnotetext{
${ }^{7}$ Norman Fairclough, Media Discourse, 56.
} 
conventions. Literacy is also involved since these messages are written (and read) instead of spoken.

John Swales also writes about discourse communities and the genres they use. His conception is a useful way to summarize how the genres in this discussion thread and on Melungeon-L more broadly function within the community of the list. Writes Swales, "Discourse communities are sociorhetorical networks that form in order to work towards sets of common goals. One of the characteristics that established members of these discourse communities possess is familiarity with the particular genres that are used in the communicative furtherance of those sets of goals. In consequence, genres are the properties of discourse communities." ${ }^{8}$ The patterns of assertion, amendment, challenge, and reply have developed on the list, and, when a new topic is announced, listers have an appropriate array of genres to choose from. They don't agonize over how to construct their messages, but, because they are in "Melungeon-L mode," they just start typing.

\section{CONVERSATIONS ONLINE}

Harriet Wilkins's study, "Computer Talk," affirms the fact that computer conversations are an example of an activity that is traditionally oral taking place in written form. ${ }^{9}$ The switch from oral face-to-face interaction, which is a very rich mode that contains visual, auditory, and gesture cues as well as words, to the leaner more limited graphic mode mandates that accommodations must be made. ${ }^{10}$ Computer-mediated discourse, CMD hereafter, has elements of both writing and speaking. Since Melungeon-L is

\footnotetext{
${ }^{8}$ John Swales, Genre Analysis: English in Academic and Research Settings, (Cambridge, UK: Cambridge University Press, 1990), 9.

${ }^{9}$ Harriet Wilkins, "Computer Talk: Long-Distance Conversations by Computer," Written Communication 8 (1991): 57.

${ }^{10}$ Susan Herring, "CMD." 614.
} 
asynchronous, writers have the capacity to edit and format their texts. However, it is different from other forms of writing in that exchanges are usually much faster than sending letters or publishing a text and waiting for a response. In addition, one writer is able to publish instantaneously for many readers (the list subscribers) and to follow multiple threads of conversation. One feature of CMD that Herring points out is that, although the audience for messages is unseen and sometimes unknown, there is "an impression of direct and even 'private' exchanges."11

Some sociolinguists have theorized that CMD is not really suitable for social interaction; however, according to Herring, "there is ample evidence that users compensate textually for missing auditory and gestural cues, and that CMD can be richly expressive." 12 This is, in fact, one of the primary conclusions drawn from my study: community on several different levels was enacted and maintained during the "Melungeon herbal medicines" thread in the social space of Melungeon-L.

Mark Stefik makes a similar point in his introduction to one of the essays in his book. He alleges that people use email primarily for social purposes and suggests that the technological view, which emphasizes information sharing and retrieval as well as the particularities of email communication, sheds less light on the use of computer network capabilities than the social view. He writes, "In the social view, people search for affiliation, support, affirmation, and community. They gather together, chat, and confide. They look for others with common interests and form groups." ${ }^{13}$ The most apparent group that formed in the context of the "Melungeon herbal medicines" thread was a small

\footnotetext{
${ }^{11}$ Susan Herring, "CMD." 614.

${ }^{12}$ Susan Herring, "CMD." 614.

${ }^{13}$ Mark Stefik, Introduction to "Some Consequences of Electronic Groups" by Lee Sproull and Samer Faraj, Internet Dreams: Archetypes, Myths, and Metaphors, ed. Mark Stefik. Cambridge, MA: MIT Press, 1996, 125-26.
} 
group of "Ridge Onlys." Their sense of kinship, related to their shared ideology, was reinforced by the opening invitation to share herbal remedies that came from "Frank." Wilkins outlines several strategies that computer conversationalists use to develop feelings of intimacy: validation, the use of names and previous lexical items to open entries; ego involvement, use of first person pronouns and phrases referring to mental processes such as "I think" or "I know"; involvement with the hearer, use of second person pronouns and/or the name of the person being addressed and by posting or answering questions. ${ }^{14}$ These things did occur in this discussion thread; distribution of these elements is shown in the table below.

Table 7: Strategies for Developing Feelings of Intimacy

\begin{tabular}{|c|l|c|}
\hline Strategy & \multicolumn{1}{|c|}{ Definition } & Instantiations \\
\hline Validation & Use of names to open messages & 28 \\
\hline Validation & An expressively affirmative reply & 19 \\
\hline Validation & Use of a previous lexical item in a reply & 48 \\
\hline Involvement & Sharing of personal information & 37 \\
\hline Ego Involvement & Use of first-person pronouns & 64 \\
\hline Involvement & Reference to mental processes (think, dream, etc.) & 26 \\
\hline Involvement w/ hearer & Use of second-person pronouns & 28 \\
\hline Involvement & Use of expressions indicating personal ties & 12 \\
\hline
\end{tabular}

The table, while it is certainly accurate, does not indicate the rich and varied nature of the conversation. One participant signed off with the closing "Hugs." Another says, "Love and health in family ties." And yet another calls herself "WV Hillbilly ." The writers sometimes address the list by a general greeting such as "Hello" or "Good Morning" (15 instances), and they often end messages with a signature (64 instances).

\footnotetext{
${ }^{14}$ Harriet Wilkins, "Computer Talk," 67-68.
} 


\section{MEMBERSHIP}

Wilkins also mentions the importance of the sharing that occurs in computer conversation as a community-building agent. In her study of computer mediated discussion on Presbynet, she asserts that participants "revealed knowledge that they shared prior to the conversation, established new spheres of shared knowledge and developed norms for membership." ${ }^{, 15}$ Another socio-linguistic researcher who investigated ways of understanding membership as a crucial part of understanding community is Harvey Sachs. His lecture titled "The MIR Membership Categorization Device" details one of his ideas about how a community works.

The herbal medicine thread appears, on the surface, to explore a safe topic. At the same time that this thread occurred, Melungeon- $\mathrm{L}$ was embroiled in a heated discussion of a critical issue, who can be included in the group labeled "Melungeon." The membership discussion was prompted by opinions and comments concerning an ongoing DNA testing project. This project had been proposed and was then being coordinated by Brent Kennedy, who had succeeded in finding a biologist, Dr. Kevin Jones, at University of Virginia at Wise, where Kennedy was then an administrator, to oversee the testing and analyze the results. In early 2002 , list members, some of whom had provided DNA samples for the testing, were eagerly awaiting the announcement of the results at the upcoming Fourth Union Melungeon Gathering and arguing about how participants for the study had been recruited. The arguments being offered are at the center of Melungeon discourse since they were primarily about membership in the group labeled "Melungeon" as well as being about a definition of the term "Melungeon" and what counts as evidence

\footnotetext{
${ }^{15}$ Harriet Wilkins, "Computer Talk," 73.
} 
to support claims in both catgories. I thought at first that the "Melungeon herbal

medicine" thread was really about herbal medicine, but upon analysis found it to be, in addition, about affirmation or denial of membership.

Focusing on the social aspects is not to say that no information was exchanged.

Many of the posts gave particulars about herbal/home medical practices that occurred both in mountain communities when the contributors were growing up or in places like Cincinnati where Appalachian people, some of whom were Melungeon descendants, migrated to find work during and after World War II. The tables below show a distribution of general subject headings and a listing of exact subject headings. It is interesting to note that from the original topic of herbal medicine, the discussion morphed into talk about faith healing and snake-handling.

Table 8: Subjects of Messages, "Melungeon herbal medicines" Thread

\begin{tabular}{|c|c|}
\hline Total number of posts & 80 \\
\hline Posts about specific remedies & 41 \\
\hline Post about snake-handling & 23 \\
\hline Reminiscing about Jack Goins, deceased & 4 \\
\hline Apology sequence (MIR Modifier, Modified) & 3 \\
\hline Posts debunking herbal medicine & 2 \\
\hline Other & 7 \\
\hline
\end{tabular}

Table 9: Subject Headings List

\begin{tabular}{|l|c|}
\hline \multicolumn{1}{|c|}{ Exact Subject Headings } & Number of Posts \\
\hline Melungeon herbal medicines & 29 \\
\hline Medicine (medicine) & 14 \\
\hline Snake Handler (Snake-Handlers) & 10 \\
\hline 4TUH2D (acronym "Fortitude") & 3 \\
\hline asafetida & 3 \\
\hline old remedies & 3 \\
\hline An Apology to the List & 3 \\
\hline Reading Cobwebs & 2 \\
\hline Stovewood & 2 \\
\hline OLD TIME REMEDIES & 2 \\
\hline Praise the Lord, pass the serpents in Georgia & 2 \\
\hline this list & 1 \\
\hline Medicine Twanda & 1 \\
\hline Melungeon-D Digest Vo2 \#85 & 1 \\
\hline Snake Handler/Healer & 1 \\
\hline OT Onion Recipe Charlene & 1 \\
\hline Mustard plaster & 1 \\
\hline
\end{tabular}


Subject headings do provide continuity within the discussion thread. Some writers write new messages with specific subject headings. Others hit "Reply" and write in what they want to say without deleting any of the previous message(s). Still others copy a particular paragraph, sentence, or phrase they wish to reply to. It is possible sometimes to determine that a message, although separated by a significant amount of elapsed time and preceded by a number of posts that already responded to a message, is a direct response to a particular previous post by looking at all the clues a message contains. The three strategies for positioning a message within the thread outlined just above are all important in reconstructing the web of the discussion thread's messages.

As my oval chart on page 291 shows, the two identifiable groups that contributed to the "Melungeon herbal medicines" discussion thread are a small core of people I am designating "Melungeon contributors who can document their heritage" and a larger group of list members who participated in the expanding discussion. Four of the 33 participants in the herbal medicine thread demonstrated in their messages that they know each other face-to-face and that they belong to this smaller group. The four writers in this "inner" group contributed 29 messages or $36 \%$ of the corpus.

These four persons responded to a call to contribute by a definite and exclusive invitation in the first message of the thread. The writer of this invitation has a typical Melungeon surname but was not at the time a regular list contributor. He issued his challenge in the very first clause of his post, "Is there anyone on this list who is sure of their Melungeon background [italics mine] and has family information on any of the old herbal medicines." This clause invited the "true Melungeons" to participate and effectively silenced others (at least initially) who cannot prove their heritage and who 
were very aware of that fact in the other simultaneous list conversation. Once the subject headings began to vary, more people not in the "Ridge Only" group began to offer their knowledge of herbal/home remedies.

The four inner circle participants (Twanda Smith, Cleland Thorpe, Jack Goins, and "Patsy Neff") contributed very short initial messages in conversation with each other very quickly in the first three days, $1 / 30,1 / 31$, and $2 / 1$. Their messages list and recall various remedies, talk about who administered them (often a grandparent), lament the death of a loved acquaintance - "Jack Goins of Washington state"- and reminisce about the "good old days." Wrote Twanda Smith: "Gosh this is bringing back memories, ... remembering the good ole days brings joy."

\section{SACHS'S MIR CATEGORIZATION DEVICE}

Harvey Sachs alleges that his discoveries about how group membership categories work are central to understanding the way that social interaction works. ${ }^{16}$ His schema is outlined in the chart below.

Table 10: Sachs' Membership Categories
\begin{tabular}{|c|l|l|l|}
\hline Initial & \multicolumn{1}{|c|}{ Stands for. . } & \multicolumn{1}{c|}{ Definition } & \multicolumn{1}{c|}{ Examples } \\
\hline M & Membership & $\begin{array}{l}\text { A “which-type" category that classifies } \\
\text { a person within a population }\end{array}$ & $\begin{array}{l}\text { sex, age, race, relation, } \\
\text { occupation, or Melungeon }\end{array}$ \\
\hline I & "Inference-rich" & $\begin{array}{l}\text { Much of the knowledge that members } \\
\text { of the society have about the society is } \\
\text { stored in terms of these categories. }\end{array}$ & $\begin{array}{l}\text { If you say a person is an } \\
\text { engineer, you infer many } \\
\text { things about him/her. Or, by } \\
\text { extension, if you say a } \\
\text { person is Melungeon. . }\end{array}$ \\
\hline $\mathbf{R}$ & Representative & $\begin{array}{l}\text { Any member of any category is } \\
\text { automatically a representative of that } \\
\text { category. }\end{array}$ & $\begin{array}{l}\text { If you are a member of a } \\
\text { particular category, you are } \\
\text { presumed to be an expert } \\
\text { about that category. }\end{array}$ \\
\hline
\end{tabular}

\footnotetext{
${ }^{16}$ Harvey Sachs, “The MIR Membership Categorization Device," Lecture 6 in Lectures on Conversation ed. Gail Jefferson (Oxford, UK, \& Cambridge, MA: Oxford University Press, 1995), 40-41.
} 
Sachs further states that the MIR device becomes a means for social control. Consider this example: an event occurs and is known by the name of the person who did it. "John did X." Now, substitute the name of John's category, "A such-and such did X." this statement can add to the store of knowledge about a particular category or can serve to monitor behavior, as "Remember you are a such-and-such. ..." This sort of system is "operated by and enforced by and taught by and used by members of the category whose members are to be controlled." 17

The word "Melungeon" is heavy with meanings in Appalachia. Without understanding the debates that rage about the etymology of the word, many residents of the region know about Melungeons and understand what being Melungeon might mean. In his ongoing crusade to make the word mean more than simply persons who can trace their lines back to one of the documented Melungeons of Hancock County, Brent Kennedy wrote late in 2002, partly in response to the debates that are so evident even in the "Melungeon herbal medicines" thread and that had raged on the email list and had finally resulted in the creation of the Historical Melungeons website,

$[T] \mathrm{o}$ those who claim that only a handful of families in Hancock County, Tennessee, were ever referred to as Melungeons, I can tell you that thousands of people in Wise and Dickenson Counties, Virginia would disagree. Long before I was born, the so-called "Ramps" of Stone Mountain and Coeburn Mountain were also referred to as "Melungeons," probably a term that followed their ancestors there from earlier stopovers in Hancock County, Tennessee. I personally knew of our County's Melungeons as a child, long before I knew of those wonderful folk

\footnotetext{
${ }^{17}$ Harvey Sachs, "The MIR Device," 43.
} 
in Hancock county. This is not to say that our locals were correct in their nomenclature, but instead only to say that the term was in use, correctly or incorrectly, pre-Brent Kennedy. ${ }^{18}$

Persons on the list certainly knew all the issues that Kennedy alludes to as well as those he is stating outright; the knowledge for list members was layered and further defined by each individual's network of interpretation. The "Melungeon herbal medicines" thread was a microscopic prelude to the uproar that caused Kennedy to make his statement. The following lists are my attempt to codify the information that is necessary for an outsider to understand the herbal medicines thread in its context (list-shared knowledge and Appalachian-shared knowledge).

\footnotetext{
${ }^{18}$ Brent Kennedy, "Statement 12-03-02" [Website] (20020; available from http://www.melungeons.com; Internet; accessed 25 June 2005.
} 
Table 11: What "Melungeon" Can Mean

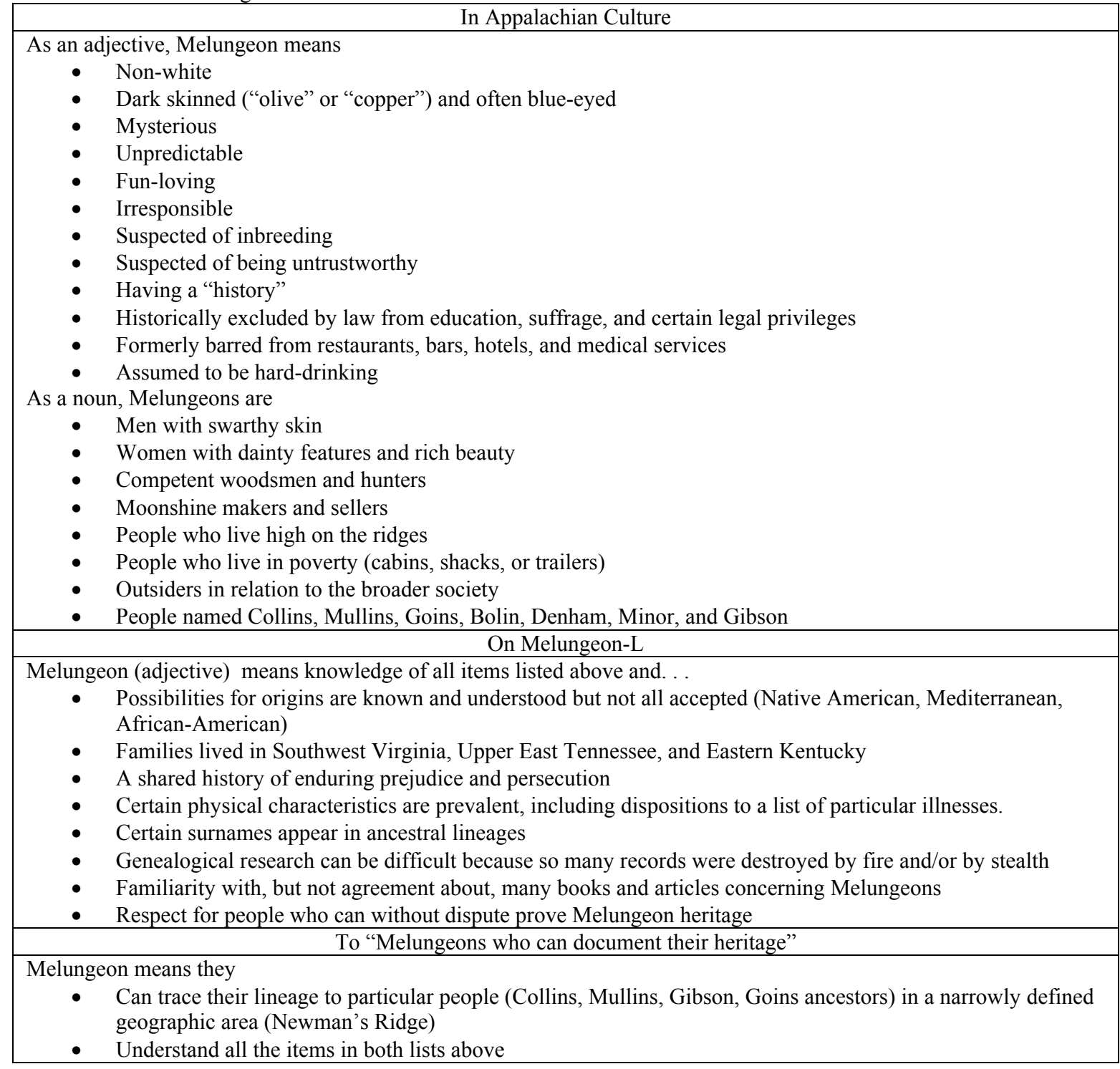

From this chart it is easy to see that the term "Melungeon" is a loaded word, certainly "inference-rich." It is also easy to see that calling someone a Melungeon could be a compliment, an insult, or every possible gradation of terms between those two. Where that caller is situated socially would have much to do with what such an invocation might mean. The hearer would have to decide from her perspective what is meant. ${ }^{19}$

\footnotetext{
${ }^{19}$ Harvey Sachs, "The MIR Device," 45.
} 
Or, to put this another way, a person's ideology would determine whether or not she might be offended. Some list comments provoke ire because writer and reader inhabit opposite sides of an ideological divide.

When one contributor to the thread who is in the "Melungeons-who-can-provetheir-heritage" group says, "You bunch of Melungeons should have been in eastern KY. They used 'white lightning' for everything," she is using the term "Melungeon" affectionately; it is an affirmation of solidarity. ${ }^{20}$ No one in the inner circle takes offense. In fact, the four major players proceed to enact a tableau on the "stage" provided by the public forum of the list. Few others add anything in this early stage; the smaller group is performing a story-telling function for the list as a whole — articulating and affirming shared knowledge.

One additional observation about the importance of this idea of membership categories: Sachs maintains that two-set classes often arrange themselves into what he calls "the have" and the "don't haves." ${ }^{21}$ On Melungeon-L the "haves" are the true Melungeons; the "don't haves" are everyone else who is not verifiably Melungeon. Melungeons, who have traditionally been in a one-down position in Appalachian society, are on top on the list, a fact that they stridently affirm. The "haves" do their best to exert social control. Those who are Melungeon set the tone and establish the "rules" for list behavior that function alongside the official list guidelines that a subscriber automatically receives. Contributors who do not conform are flamed by inner-circle members, even though flaming is expressly forbidden in the official guidelines. Sometimes reprimands are delivered privately as the following example implies.

\footnotetext{
${ }^{20}$ Robert Hodge and Gunther Kress, Language as Ideology $2^{\text {nd }}$ ed. (New York: Routledge, 1993), 157.

${ }^{21}$ Harvey Sachs, "The MIR Device, 48.
} 


\section{AN INTERESTING ANCEDOTE: AN MIR MODIFIER FURTHER MODIFIED}

MIR modifiers are ideas in contradiction to normal expectations about members of a category. Such a modifier says "what it is that may be said about any member [of a category] is not to be said about the member at hand."22 One of the examples of this phenomenon that Sachs articulates includes this statement: “I'm 48, but I look much younger. I look about 35, and I'm quite ambitious and quite idealistic and very inventive and conscientious and responsible. ${ }^{, 23}$ Visible here is a category-being 48 - and a whole string of qualifications. The person understands what set of characteristics his hearer may apply to the category of being 48, and he is quick to say that the presuppositions aren't so.

There also exists a dangerous reversal of this modification phenomenon, where the process goes into effect in an opposite sort of way. Consider the following example. Sometimes a person can be classified by a negative reference to one of these modifiers. The first statement would look like this: "He's an alcoholic, but the things you can say about alcoholics you can't say about him." Then the person under discussion suddenly is seen to belong to the original category after all, "Well, now it really comes out. .." and the original set of characteristics that can properly be said about the category is invoked. The effects of the modifier are removed, and a hurtful situation is enacted. A visual representation of this scenario is just below.

Table 12: Representation of the MIR-Modifier-Modified Situation

\begin{tabular}{|c|c|c|}
\hline Category's implications & Modifier & Anti-modifier \\
\hline- & + & - \\
\hline
\end{tabular}

\footnotetext{
${ }^{22}$ Harvey Sachs, "The MIR Modifier," 44.

${ }^{23}$ Harvey Sachs, "The MIR Modifier," 44.
} 
The inferences that are inherent in the term "Melungeon" build in the possibility for just such a situation - the modification and the anti-modification of the Melungeon category. There is an instance of this phenomenon in the herbal medicine discussion. Toward the very end of the thread a number of list subscribers were exchanging messages about snake-handling and snake-handling churches. In the course of these messages, Ramona Woods contributed this posting.

Hello,

I don't understand your problems with the Snake Handlers - they are very nice people. I admin the Snake Handlers mailing list and board — and speak to many of the Ministers of the Snake Handling Churches.

One would think that coming from ancestors that many of you state were discriminated against — it seems you as a group would not show discrimination against any other group of people.

IMHO

Ramona

It appears that this writer thinks the "Melungeons" on the list are saying one thing about what it means to be Melungeon and doing another. Here is my analysis of what may be occurring here.

Table 13: Inferences and Their Values

\begin{tabular}{|c|l|c|}
\hline Membership Category & Inferences & Value \\
\hline Inferences & $\begin{array}{l}\text { Melungeons are not trustworthy, not } \\
\text { "white," not desirable, etc. }\end{array}$ & - \\
\hline Modifier & $\begin{array}{l}\text { Melungeons have suffered persecution } \\
\text { and know what discrimination feels } \\
\text { like. This makes them tolerant. }\end{array}$ & + \\
\hline Anti-Modifier & $\begin{array}{l}\text { You (Melungeons) are discriminating } \\
\text { against snake handlers; you're } \\
\text { behaving badly }\end{array}$ & - \\
\hline One Step More & $\begin{array}{l}\text { Why don't you act like the people you } \\
\text { represent yourselves to be (and that I } \\
\text { take you to be) and demonstrate } \\
\text { tolerance? }\end{array}$ & + \\
\hline
\end{tabular}


Ramona's allegation— - it seems that you as a group would not show discrimination against any other group of people"-is offered with a hedge, "IMHO," which stands for "in my humble opinion." What follows is my description of what has happened here in terms of Sachs MIR theory: The general public may have negative perceptions of Melungeons [category], but people on this list are not that way at all [modifier]. However, now some list members are being uncharitable about snakehandlers, who are "very nice people" [anti-modifier]; it's a case of Melungeons acting just like the stereotypes would lead one to expect. My description replicates the situation Sachs describes. I offer, that in this case, the situation escalates one more notch. Woods adds a final exhortation to list members to act positively because of who they are and what they have suffered: Woods implores the list members to refrain from showing any discrimination.

Although several list members (but not any of the inner circle Melungeons who can document their heritage) jumped into the discussion and supported both Woods and the snake handlers, I suspect that someone challenged her off-list because two days later she sent this message titled "An Apology to the List":

Hello,

If my message regarding the Snake Handlers offended anyone I apologize.

I meant no offense to anyone.

Ramona

The only thing that might have offended anyone is the allegation that "Melungeons," who have ancestors who were discriminated against, are persecuting someone else-in this case the group that Ramona Woods represents, the snake handlers. 
The list owner, Dennis Maggard, reassures her on the list saying, "No offense was taken that I know of." However, it seems that there could be more here than the archived list messages show.

\section{THE INITIATOR OF THE "MELUNGEON HERBAL MEDICINES” THREAD}

The initiator of the thread, although he has a Melungeon surname, is an unknown person to the small inner group. Another piece of what is going on during this thread is the insiders' trying to determine just who he is and to whom he is related. This probe takes place in public messages, yet it is also happening off-list because one message that is sent to him off-list is posted to the list as a footer within his reply. Twanda Smith apparently wrote off-list,

"Fred"

Please tell us more, you seem to be well versed and up on a lot of things? Did you have family that left you the joy of knowing something about your heritage?

Hugs,

Twanda

He replies to the list and in the process opens up a new direction within the general topic of herb medicines:

Both my parents are Melungeon. I have Gibson, Mullins, and Collins ancestors. I would like to add to the information I already have on Melungeon herb medicines. ... Also am interested in faith healers. Brother Claude Ely is probably the best known even though he is better known for his music. 
This message starts the comments about snake handling as a common practice and occasioned an attempt to identify by name a particular snake-handling faith-healing preacher who roamed Harlan County, Kentucky, in the 1940s-1950s. In a later message "Fred" in a clever and ironic reconstruction of "Melungeonness" shows that, while he may be able to trace his family lines to the significant ancestors and to Newman's Ridge in Hancock County, Tennessee, he is not quite ready to take up a position in the inner circle (this is a long message, but definitely worth reading; it's nuances are classic):

Someone on this list asked earlier if I was melungeon. Am I Melungeon?? I have always been told our ancestors were melungeons but after reading the posted email from this list I am not sure anymore. We have no family history of mental illness, hypochrondria (Oops that last word is badly misspelled or is this another one of this lists [sic] characteristics of the melungeons) or any disease associated with inbreeding. I asked my 99 year old [sic] great grandfather if he had ever heard of incest in the family or if he had personally had sexual relations with his mother or sisters or even his father [sic] and he came off of his treadmill and hit me with his cane. I take that as a definite no. We exercise regularly, try to eat right, are not overweight, stay as active as possible, and take no medications except a few multiple vitamins. We don't have cardiac or lung problems either. We have never been diagnosed with any psychological disorder or required hospitalization in an institution of any kind. Great grandfather's father did develop lung problems when he was young and forced to work in the mines [sic] but he saved his money and got the family the hell out of that coal camp and worked three jobs so my great grandfather could go to Hampton Institute. We do 
however have all the physical attributes that you describe especially the shovel teeth....

Signed "Fred "[two common Melungeon surnames]

Cleland Thorpe follows this message up on-list with comments and deductions:

You gotta be a friend of Jack Goins. Anyway, I liked your little family history and your reasoning as to why you may not be Melungeon. Also like your name. Now, if you are any kin to those Collins on Newman's Ridge, then we are probably kin. Martin Collins was My G-G-Grandfather.

Cleland

If "Fred" responded to Cleland and further discussed his insider-group membership, the interchange happened off-list.

"Fred's" long message is a tongue-in-cheek commentary on list topics and personalities of some list contributors. He is specifically addressing the issue of physical markers to identify Melungeons. He weighed in again on this issue in November of 2003 on the Historical Melungeons discussion list in a sarcastic interchange with Nancy Sparks Morrison. "Fred" continued to post to Melungeon-L from time to time after the "Melungeon herbal medicines" thread ended. The last post I noticed was in June 2004 when he was making negative comments about the MHA and the Unions, one of which was scheduled to occur some days later. His voice in the herbal medicine thread felt emotionally neutral. He exhibited knowledge about the Melungeons and a sense of humor about some issues in Melungeon discourse. He seemed to be asking an honest question. Subsequent messages on various topics revealed a more sarcastic and strident persona 
and an ideology closer to that of the "historical Melungeons" described in detail in Chapter 6.

"Fred's" initial post raises important considerations of power dynamics. In social settings such as the community of this email list, the use of language is always connected to the exercise of power. These connections may not always be clear to the persons involved, but power in any social group does reside in the language group members use. In the "Melungeon herbal medicines" discussion thread, the exclusionary nature of the initial invitation to "anyone of this list who is sure of their Melungeon background and has family information of any of the old herbal medicines used" not only limited the discussion to particular people but also dictated what information would be shared. The entire thread of 80 messages must be put into the large framework of all dialogue that happens on the list and also into the particular context of this restrictive opening message and writers' responses to it.

The list's "inner circle" of those who can document that their ancestors are among those "first families" on Newman's Ridge had ultimate power on the list in 2002. "Fred" actually proved himself to be a member of that elite group by telling who his ancestors were even though he was not a list regular. The power relation herein described was enacted and maintained with language as the primary tool. And, that language, which bore many of the markers of oral casualness and spontaneity, in fact did significant work. In this case, on an email list, written language was the instrument of power dynamics.

\section{A GOOD STORY, TOLD AND RE-TOLD}

In the course of the list talk about snake handling, Jack Goins tells a story. 
I heard a man tell a story about the time he attended one of these church meetings, not realizing it was a Snake handling church. When they came out with the snakes [sic] he was sitting on the front pew [sic] and he looked at the preacher and said PREACHER!! Where is the back door, [sic] the preacher told him there was no back door, [sic] his reply was "where do you want one at." (I believe that person [sic] name was Wendie Bagwell?) Jack

In less than ten minutes, a list member responds with information about Wendy Bagwell, who was a Southern gospel performer with a backup group called the Sunlighters. About an hour later Twanda Smith offers a comment:

HAHAHAHAHHA Jack [sic] I was standing talking with Wendie and Mr. Stamper at the Southern Gospel Convention few year ago [sic] and he told me that story. HEHEHEHHE I can just imagine the hole that he made in his exit. He was scared to death of snakes. Twanda

About 40 minutes later there is another telling of the story:

Hey Jack, I have an old Wendy Bagwell 8 track. On it he said he and his daughter was [sic] in the pulpit singing when a woman jumps up and starts swinging a huge snake. He said he whispered to her 'Honey look around quietly and see where the back door is.' She says 'Daddy there isn't one' so he tells her 'Well Honey look and see where you think they would like one.' He was a very funny man.

Finally a third version of the story appears with Andy Williams as the main character. The writer, who narrates the story one more time, seems unaware that a version of the story (or is this a "rural legend"?) had already been told. This post had a different subject heading, "Snake Handlers." It could be that the writer was not reading the messages titled 
"Melungeon herbal medicines," perhaps because of the exclusionary opening of that subject, but was reading the messages titled "Snake Handlers."

Inside the world of Melungeon studies, the preacher story is a favorite genre. Two of the "Melungeon Tales" collected by the WPA/Tennessee Writers Project are preacher stories, and the genre is explained and discussed in Saundra Keyes Ivey's doctoral dissertation about the oral and print traditions as they relate to Melungeons. The anecdote about a gospel singer at a snake handling church fits nicely into the preacher-story category, where the preacher usually plays the fool. In this case, it is another type of religious professional, the Southern gospel-singing minister who plays the preacher's role.

\section{WHAT I DISCOVERED}

My original research question for this project was "How is community enacted and maintained in the "Melungeon herbal medicines" thread on Melungeon-L? I found that community on the list in January/February 2002 had two meanings. There was one community of "historical" Melungeons who can trace their family lines back to those hardy pioneers who settled on Newman's Ridge around 1800. They know their heritage, and they are proud of it. They have a store of knowledge in common that they delight in sharing. The list was a place where, even though they are no longer located together in space, they came together in a virtual place to perform as storytellers and to preserve ideas about how life used to be for the Melungeons of Hancock County, Tennessee.

There was a second much larger group of people who were list contributors. These persons may have been list subscribers for a variety of reasons - nostalgia for 
Appalachia, searches for genealogical information, research, supposed kinship deduced from Brent Kennedy's book, or some other suspected connection to Melungia. This group wanted to learn the lore from those on the inside, gather information about their own ancestors, listen to all the conversation, and participate in some of it, but they could not enter the inner circle unless they could document their blood connection to the first families.

The third, and probably the largest group of all, was and still is the lurkers - those who subscribe and receive the list messages but never contribute. Can they even be counted as community members?

Because my study looked at an online community, the original version was a website (http://www.hu.mtu.edu/ kgvande/laprojectindex.htm), and I used a MOO to deliver the content to my graduate school classmates. I invited Wayne Winkler and List Owner Dennis Maggard to participate in the MOO session as resource persons to answer questions and to comment on my analysis. Winkler did participate. Maggard did not.

My presentation MOO occurred in April 2002. In June of that year I went to Fourth Union and gave a presentation there related to my book, How They Shine: Melungeon Characters in the Fiction of Appalachia. I prepared a handout to go with my talk that told a little about my book, myself, and my plans to write this dissertation. I wrote: "Her doctoral dissertation will investigate how the Internet has influenced Melungeon people. She is particularly interested in looking at the increasing number of websites and in analyzing conversations on Melungeon-L at Rootsweb, the genealogy discussion list." That summer, when I was studying for comps, the dissertation was merely a dream, but one person who received the handout was clearly offended. Joanne 
Pezzullo posted the above-quoted sentences from my handout on Melungeon-L, irate that an outsider would dare to "analyze" list conversation. In a thread of close to 70 messages, listers cussed and discussed my plans, their focus on my word "analyze." Helen Campbell and Dennis Maggard both came to my defense saying that my intentions were honorable, my study (already completed) had been very open, people in the thread had given permission to be quoted, and the thread itself was insignificant. At the time of the uproar, I was unsuscribed and unaware that not my real work—book, website, or conference presentation - was being criticized, but instead just one word from my handout sheet was sending Melungeon listers into orbit.

The upshot of the discussion was a public apology to me from Dennis Maggard. When I read it I understood that he had not logged on for the MOO session in April because he had originally disagreed with my conclusions - inner and outer groups, trial by pedigree. However, his apology came the following autumn at the same time that Pezzullo was mounting Historical Melungeons. Maggard admitted that I was "on to something." He said he had not realized at the time what was going on, but had come to appreciate the truth and importance of my findings. He copied me on that message even though I was not then subscribed to the list. Sweet gratification!

It's easy now to look back and see that not only were my conclusions true, they were prophetic. I saw the "true" Melungeons flaunting their lineages and establishing their boundaries, and I could, at least in sociolinguistic terms, prove that the divide between them and all others was real. In January and February, the "Melungeons who can document their heritage" were still talking with others who were not so sure about where they fit into the Melungeon saga. However, by autumn the Historical Melungeons 
website and its accompanying email list were up: The difference of opinion about who could be included and what counts as evidence had become a schism.

\section{REIFYING ETHNICITY}

One Schema for understanding the purpose and practice of Melungeon- $\mathrm{L}$ is the idea of ethnogenesis or the process of establishing ethnicity. In his 1991 article, Thomas Fitzgerald discusses the impact of electronic media on ethnic identity formation. Although he based his argument on the prevalence of radio and television, his conclusions seem equally valid for Internet use. Fitzgerald uses Meyrowitz's 1986 book, No Sense of Place: The Impact of Electronic Media on Social Behavior, as his starting point and then reaffirms that "electronic media allow people to escape from traditional place-defined groups. ${ }^{24}$ Meyrowitz argues that electronic media change social geography. This is certainly true for email listservs in general and Melungeon- $\mathrm{L}$ subscribers in particular. No matter where people live or which time zone they are in, the asynchronous email format allows participants to come to "the Place" - the online forum—at will and add to the ongoing conversations or just to bask in the aura of virtual reality. As early as 1997, Mary Goodyear, the list's founder noted that listers seemed like family, so not only was there a new place, but it was also as comfortable (or sometimes as uncomfortable) as the chairs around the kitchen table.

Fitzgerald's point is that even though the broader culture is becoming more uniform, "some ethnic groups try at the same time to differentiate themselves by deliberate appeals to traditions (the 'survival of cultural baggage' metaphor) and

\footnotetext{
${ }^{24}$ Thomas Fitzgerald, "Media and Changing Metaphors of Ethnicity and Identity," Media, Culture, and Society 13 (1991): 194.
} 
reinterpretations of past history." ${ }^{25}$ Even though in the past the term "ethnic" had negative connotations, Fitzgerald maintains that ethnicity has been transformed from a social liability to a desirable identity. ${ }^{26}$ For the Melungeons, where their historically inferior status was based on race—on skin color—and their former goal was the "white" designation, emerging as a recognizable dark-skinned group in today's more tolerant climate gives them cultural capital where none existed before.

According to Fitzgerald, "[a]n interesting paradox is that the most vocal champions of cultural revivals are almost always the educated elites among such minorities. This is paradoxical because the slogans of 'ethnogenesis' are formulated by the very people farthest removed from their traditional culture. ${ }^{, 27}$ Although this article was written in 1991, before Brent Kennedy's Melungeons: Resurrection of a Proud People, it describes what has occurred among the Melungeons (and the people who want to be Melungeons) since then. Countless numbers of people on the email list, at the Unions, and in Appalachian communities relate having had an almost "conversion-type" experience when they read Kennedy's book. The sense of resonance and realization that their own family histories have embodied similar experiences is strong for many people. Kennedy is certainly a member of the academic elite-Ph.D. in Communications, university administrator, articulate speaker, gifted writer, and (by his lights) Melungeon. The Melungeon Movement as it exists today is at least in part due to the notoriety of this book and its author.

\footnotetext{
${ }^{25}$ Thomas Fitzgerald, "Media and Changing Metaphors," 195.

${ }^{26}$ Thomas Fitzgerald, "Media and Changing Metaphors," 196.

${ }^{27}$ Thomas Fitzgerald, "Media and Changing Metaphors," 199-200.
} 
Another factor to consider is the economic one. Melungeons living in the southern mountains in the 1920s and 1930s had little cash; as I already noted, many families used the barter system to get the variety of foodstuffs they needed. Few households had money to buy a radio, and, if they did, it took an elaborate hook-up of an automobile battery or generator to get the thing working because there was no electricity in rural areas. Today, Melungeons still living in the valleys and on the ridges take electricity, phone service, and even Internet access for granted. Outmigration has radically altered the geographical distribution of Melungeon families. Few of them remain on the land. But, the new virtual places, the websites and the email discussion lists, welcome Melungeon descendants and even Melungeon wannabes 24/7. People feel that they belong to "the Melungeon family" at a time when the traditional idea of the family is in transition in American culture.

The conversations and the arguments on Melungeon- $\mathrm{L}$ are certainly about ethnic identity—having a history and knowing about it has value. In the "Melungeon herbal medicines" thread, there was evidence that definite boundaries had been established. The inner group was solidifying their position and, in retrospect, preparing to form a new community where their understanding of what it means to be Melungeon would not be challenged. Even though Melungeon culture was in many ways practically indistinct from Appalachian mountain culture in the past, the Melungeons can, through the email discussions and the websites, now stake their Melungeon claim on "difference," an emerging ethnic identity. 


\section{WHAT HAS HAPPENED AND WHY}

The decline of Melungeon-L is lamented by some and celebrated by others. In his 2003 paper about Melungeon use of the Internet, scholar Jacob Podber talks about his perceptions of the listserv. He terms it a ritualistic form of communication maintaining a society in time that does not have geographic location, an idea that is similar to Fitzgerald's. Writes Podber, “To a certain extent, the Melungeons have been both culturally constructed and self-defined. Their use of the Internet has allowed the community to reach out beyond its geographical borders to form an electronic virtual community." 28

Podber interviewed many people in the Melungeon online community to draw his conclusions. Nancy Morrison, the creator of The Melungeon Health and Support Network website said, "I never really felt I belonged. ... [W] [Wen I found the Melungeons and the first time I went to Wise, Virginia, I felt like I was coming home. It amazed me, the emotional feeling that I got." ${ }^{29}$ The same feelings of family solidarity that Goodyear expressed were still evident at the time Podber interviewed Morrison. Another participant in Podber's study is Cleland Thorpe, who is one of the insiders in the "Melungeon herbal medicines" thread. Thorpe talked about the connected feel of his relationships with others on the listserv, "I talked to people in California and I then talked to people, by e-mail, in Arkansas and Tennessee, up in Ohio and it was just, you know, it's really weird how we

\footnotetext{
${ }^{28}$ Jacob Podber, "Bridging the Digital Divide in Rural Appalachia: Internet Usage in the Mountains," (Published Proceedings, InSite "Where Parallels Intersect," Informing Science + Information Technology Education International Conference, June 2003), Available at http://www.melungeon.org/index.cgi?BISKIT=2340057430\&CONTEXT=cat\&cat=10062; Internet; accessed 6 June 2005.

${ }^{29}$ Nancy Sparks Morrison, quoted in Jacob Podber, "Bridging the Digital Divide," Available at http://www.melungeon.org/index.cgi?BISKIT $=2340057430 \& C O N T E X T=c a t \& c a t=10062 ;$ Internet; accessed 6 June 2005.
} 
all have so much in common, and it really had to come from our heritage. I mean, it passed on, it had to be. ${ }^{30}$ There was for Thorpe, too, a sense of community.

So, part of the "what," as in what happened on Melungeon-L, is the social nature of list participation. Initially, the camaraderie trumped ideology. Podber's interviews in 1999 show that. But, by the middle of 2002, ideology was winning out. Podber's assertion, that "the Melungeons have been both culturally constructed and self-defined," contained fightin" words. For the "Ridge Onlys" to admit to self-definition would have been unthinkable. The only proof good enough for them was a piece of paper in a court house, preferably one that declared the ancestor in question who had a recognizably Melungeon surname to be F.P.C. in the 1830 or 1840 census. The "why" of the deep divide was a difference of opinion about who could belong and which credentials counted as evidence. Feelings of kinship fostered by common family experiences may have been the reason for an initial connection, but real membership was based on, as Dennis Maggard phrased it, trial by pedigree.

\section{ANOTHER POSSIBLE REASON}

Scholars like theories to explain human behavior, historical trends, theological positions, and education methods. A body of theory that neatly explains the decline of Melungeon$\mathrm{L}$ is the description of how communities of practice (CoP hereafter) work in the corporate world. Although Melungeon-L is not work-related, many of the components of CoP

\footnotetext{
${ }^{30}$ Cleland Thorpe, quoted in Jacob Podber, "Bridging the Digital Divide," Available at http://www.melungeon.org/index.cgi?BISKIT $=2340057430 \& C O N T E X T=$ cat\&cat=10062; Internet; accessed 6 June 2005.
} 
theory fit this case. ${ }^{31}$ According to Wenger, McDermott, and Snyder (Wenger et al. hereafter), a community of practice is a group that shares a concern, a set of problems, or a passion about a topic, and who deepen their knowledge and expertise in this area by interacting on an ongoing basis. ${ }^{32}$ People meet (online in the case of Melungeon-L) because they find value in their interactions and satisfaction in the personal relationships they form. ${ }^{33}$ Each $\mathrm{CoP}$ has a domain of knowledge (in this case Melungeon studies), a community of people who care about this domain, and shared practice (for the subscribers to Melungeon-L their genealogical and historical research).

Wenger et al. allow that the bonds between members are strong. "What guides the actual learning of the community is an insider's view of the domain. This view may or may not be easily articulated by members, ... but it nevertheless shapes the knowledge, values and behaviors to which they hold each other accountable. ${ }^{34}$ Furthermore, leadership in the community of practice is internal and usually shared by more than one person - certainly the case in 2002 on Melungeon-L where certain researchers like Jack Goins brought one view and particular expertise and "boundary spanner" Brent Kennedy brought another perspective.

A CoP also has a "pool of goodwill" or "social capital" that allows people to contribute to the community while trusting that at some point, in some form, they too will benefit. ${ }^{35}$ In 2002, the pool of goodwill still existed; for the most part listers trusted each other and wanted to contribute to the expanding store of knowledge as well as be a part of

\footnotetext{
${ }^{31}$ Etienne Wenger, Richard Mc Dermott, and William Snyder, Cultivating Communities of Practice: A Guide to Managing Knowledge (Boston: Harvard Business School Press, 2002).

${ }^{32}$ Etienne Wenger et al., Communities of Practice, 4

${ }^{33}$ Etienne Wenger et al., Communities of Practice, 5.

${ }^{34}$ Etienne Wenger et al., Communities of Practice, 31.

${ }^{35}$ Etienne Wenger et al., Communities of Practice, 37.
} 
the "family." Wenger et al. have a diagram for a CoP that looks very similar to the diagram I made of list subscribers - the largest outer circle is of peripheral members, a smaller circle of active members, and the smallest circle in the middle of core participants. ${ }^{36}$ According to the authors, the most important aspect of the community is not the information but the web of relationships. Many list participants affirmed that they enjoyed the relationships they had with other list members. Another important aspect is the community's voice or identity. This is where the problem began for Melungeon-L. Because of their differences of opinion on the important issues of belonging and evidence, people were not willing to represented by the "voice" of the list as a whole. Wenger, McDermott, and Snyder make a final point, "even the healthiest of communities comes to a natural end. ${ }^{, 37}$ Communities either fade away, turn into social clubs that are no longer involved with knowledge creation, or split. ${ }^{38}$ The proliferation of email discussion lists on Melungeon topics indicates that the community of practice that was Melungeon-L has been replaced by several new entities where contributors are free to develop more specialized knowledge in a narrower domain.

What happened? The list divided. Why? The ideological differences polarized list members. People no longer wanted to be in community when thinking on two important issues — who can be a member and what counts as evidence — was so far from being uniform.

\footnotetext{
${ }^{36}$ Etienne Wenger et al., Communities of Practice, 57.

${ }^{37}$ Etienne Wenger et al., Communities of Practice, 109.

${ }^{38}$ Etienne Wenger et al., Communities of Practice, 109.
} 


\section{COMMUNITY IN THE “MELUNGEON HERBAL MEDICINES” DISCUSSION}

\section{THREAD}

In conclusion, then, community was enacted and maintained in the analyzed discussion thread through language typed into a keyboard and appearing on a computer screen. The moves identified by sociolinguists, things like involvement, validation, and the MIR phenomenon, showed that there were in fact several communities existing in January /February 2002 on Melungeon-L. The inner group had already defined and was policing their boundaries. Six months later, all of them were posting regularly to the Historical Melungeons discussion list and infrequently, if at all, to Melungeon-L. What I saw initially as an interesting feature of my linguistic analysis project was a portent of things to come. 


\section{Conclusion: A View from Outside}

The Melungeon story began a long time ago. If I were in a musing state of mind, I could say it began with the dispersion of the descendants of the sons of Noah or at the Tower of Babel. Those two etiological stories explain how people turned out to be different from one another. The Melungeon story is a story about difference and what difference means for people who perceive themselves to be so.

The Melungeons' marginalization, their stigma, based on skin color and ancestry, has had and continues to have profound effects on them. My argument has been that in the last century their difference, reified in part by their shared experiences, has done these things:

- Created an insider mentality, a literacy of Melungeon-ness;

- Led a particular group of them to seek outside help, from Presbyterian missionaries, to gain literacy and thereby to enhance their economic and social position;

- Pervaded their consciousness even after they mastered reading and writing;

- Made them passionate about establishing their identity through genealogy and on the Internet by creating websites;

- Caused them to exercise their power by marginalizing others who cannot prove their membership yet clamor for inclusion. 
And, why have these things played out as I have shown? Because difference—-being Melungeon - is profound, pervasive, proleptic, and inescapable.

This dissertation only looks carefully at one piece of the long Melungeon storythe literacy piece. The story of Melungeon literacy until very recently, has been about trying to erase marks of difference; some Melungeons thought literacy might make them the same as everybody else. But, literacy hasn't changed things. Melungeons still feel different even when they take the option of leaving "home" for the cities of the upper Midwest or of the Mid-Atlantic and try to blend in. Difference keeps popping up unexpectedly - a baby is born with six fingers on each hand, or an adult contracts a mysterious Mediterranean disease — and there it is, difference foregrounded again.

Like many rural Appalachian people, Melungeons during the twentieth century left the mountains to find work and financial security. The land "down home" was playing out, and there were too many people for the old patterns of subsistence farming. There just wasn't enough land when families kept dividing it into smaller and smaller plots. But, even though the people left, their hearts and their sense of who they were remained "down home." My study focuses on just one century, the one during which the Melungeons gained proficiency in reading and writing. These skills are now taken pretty much for granted, but underneath their literate veneer, Melungeon people seem the same. Distrustful of any and all power structures, they are true to the cliché, "a law unto themselves." High-strung, jittery, unpredictable, quick to take offense, and slow to forgive, they have moved their battles from the hills and hollers, from the courthouse steps and the school board hearings, to the Internet, where they wage war with written words. 
But then, isn't using language to negotiate - using letters and words as the means of making messages, to borrow Kress's definition—what literacy is all about? Reading and writing, literacy, in spite of what some people think it should do, is not about changing an individual's personality, ideology, or values. Literacy—reading and writing — is about making and receiving messages using written words. The Melungeons, armed with the literacies of difference that stem from their very natures and the nurture of their upbringings, are using the literacy practices of writing and reading to embrace the difference they cannot escape, even though over the last century many of them have tried. Brent Kennedy's dream of scholarly research about many facets of the Melungeon experience is now reality and has resulted in conference presentations and the publication of many books and articles, but for many Melungeon descendants the websites and the email discussions are where their identity crisis is being acknowledged, examined and negotiated.

Initially just recognizing difference brought Melungeon people togetherMelungeon-L and First and Second Union were successful beyond anyone's imagining. But now, less than ten years later, the family that many felt drawn to by open articulation of difference is breaking up. Melungeon-L has split; there are now many online discussion places. The Unions are offering more sophisticated research, but the audiences are smaller and more contentious both before and after. Recognizing the fact of the difference they share, finding long-lost cousins, is no longer enough to keep the family together.

I have learned a great deal, but in the final analysis, I find myself as puzzled as, and as much of an outsider as Old Man Harkryder, the crusty mountain man in Sharyn 
McCrumb's She Walks These Hills, who shrugged his shoulders and said to the sheriff, "Ain't no tellin' what them folk will do." 


\section{Bibliography}

Anthony, Ted. "Forging a Common Present from Mysteries of Long-Hidden Past Lineage: A Quest for Ancestral Secrets in the Appalachians Leads a Researcher to the Melungeon People — and to Controversy." Los Angeles Times, 28 June 1998, Bulldog Edition, A:1.

Ball, Bonnie. The Melungeons: Notes on the Origin of a Race. 1960; reprint, Johnson City, TN: Overmountain Press, 1992.

Banker, Mark T. Warren Wilson College: A Centennial Portrait. Swannanoa, NC: Warren Wilson College, 1994.

Beale, Calvin. "American Tri-Racial Isolates, Their Status and Pertinence to Genetic Research.” Eugenics Quarterly 4, no. 4 (1957): 187-96.

---------. “An Overview of the Phenomenon of Mixed Racial Isolates in the United States." American Anthropologist 74 (1972): 704-710.

Bleakley, Fred. “On-line: Appalchian Clan Mines Web Sites for Ancestral Clues.” The Wall Street Journal, 14 April 1997, B:1, col. 3.

Berry, Brewton. Almost White. Toronto: Macmillan, 1963.

Bible, Jean Patterson. Melungeons Yesterday and Today. Rogersville, TN: East Tennessee Printing Co., 1975.

Brandt, Deborah. Literacy as Involvement: The Acts of Writer, Readers, and Texts. Carbondale and Edwardsville, IL: Southern Illinois University Press, 1990.

---------. Literacy in American Lives. Cambridge: Cambridge University Press, 2001.

Brunvand, Jan Harold. The Vanishing Hitchhiker: American Urban Legends and Their Meaning. W.W. Norton and Company, 1989.

Callahan, Jim. Lest We Forget. Johnson City, TN: Overmountain Press, 2000.

---------. "The Melungeon Movement in the Past Decade." Available at http://www.geocities.com/ourmelungeons/feature.html. Internet. Accessed 21 July 2005.

---------. “Miss Mary J. Rankin,” Vardy Voice, December 2002, 7-9.

Campbell, Helen. The Melungeons (melungeons.com). Website. 2002-2005. Available from http://www.melungeons.com. Internet. Accessed 18-19 July 2005. 
Campbell, Olive Dame. “Are We Developing Dependence or Independence?” Mountain Life and Work, July 1929, 10-16.

Caudill, Harry M. Night Comes to the Cumberlands: A Biography of a Depressed Area. Boston: Little, Brown, and Company, 1962, 1963.

Cross, Robert. "Introduction to the Torchbook Edition," Christianity and the Social Crisis by Walter Rauschenbusch. New York: Harper \& Row, 1964, viii-xx.

Crowley, Sharon, and Debra Hawhee, Ancient Rhetorics for Contemporary Students, $3^{\text {rd }}$ ed. New York: Pearson Longman, 2004.

deMarce, Virginia Easley. "Review Essay: The Melungeons." National Genealogical Society Quarterly 84 (1996): 134-40.

Dewey, John. Democracy and Education. 1916; reprint, New York: The Free Press (A Division of Simon and Schuster), 1944.

Doman, Katie Hoffman. "She's Ketchable, but She Ain't Fetchable," Appalachian Life Magazine, April-May 2001: 26-29.

Douglas, Karlton, et al. “Melungeon Definition 2000” Web site 2000. Available from http://www.geocities.com/mikenassau/definition.htm. Internet. Accessed 15 July 2005.

Dromgoole, Will Allen. "Land of the Malungeons." Nashville Sunday American, 31 August 1890, at http://www.melungeon.org/?BISKIT $=2206291721 \&$ CONTEXT $=$ cat\&cat $=10014$, 27 February 2005.

---------. “The Malungeons,” The Arena 3 (1891): 470-79.

---------. “The Malungeon Tree and Its Four Branches.” The Arena 3 (1891): 745-51.

Elder, Pat. The Melungeons: Examining an Appalachian Legend. Blountville, TN: Continuity Press, 1999.

Everett, C. S. "Everett Answers Killebrew and Kennedy: A Dissenting Voice in the Discourse of Descent." Appalachian Journal 27 (2000): 129-140.

---------. “Melungeon History and Myth.” Appalachian Journal 26 (1999): 358-409.

Fairclough, Norman. Discourse and Social Change. London: Polity Press, 1992.

---------. Media Discourse. London: Edward Arnold, 1995. 
Fitzgerald, Thomas. "Media and Changing Metaphors of Ethnicity and Identity." Media, Culture, and Society 13 (1991): 193-214.

Gallegos, Eloy. The Melungeons: The Pioneers of the Interior Southeastern United States, 1526-1997, vol. 2 of The Spanish Pioneers in United States History. Knoxville: Villagra Press, 1997.

Goins, Jack H. "Definition of the Melungeons," Melungeon Heritage Association Web site. (2005). Available from http://www.melungeon.org/?BISKIT=4180855057\&CONTEXT=cat\&cat=10066. Internet. Accessed 15 July 2005.

---------. "Maybe Melungeon," Historical Melungeons. Website. 2005. Available at http://www.geocities.com/ourmelungeons/maybe.html. Internet. Accessed 25 July 2005.

---------. Melungeons: and Other Pioneer Families. Jack Harold Goins: 2000.

“'Shepard 'Old Buck' Gibson,” Historical Melungeons. Website. 2005. Available at http://www.geocities.com/ourmelungeons/buck.html. Internet. Accessed 25 July 2005.

Goodyear, Mary. Interview with Wayne Winkler. July 1997.

Graff, Harvey. The Literacy Myth: Literacy and Social Structure in the NineteenthCentury City. New York: Academic Press, 1979.

Grohse, William P. "Echoes From Vardy.” Citizen Tribune, 8 February 1981, D-4.

---------. "History of Education Vardy-Newman's Ridge Area.” Newspaper clipping with no name of newspaper or date.

----------. "Vardy: Claiborne County Community Remembers Its Heritage of Mountainmen, Moonshine.” Citizen Tribune, 19 January 1986, C1-C2.

Hale, W. T. and Dixon L. Merritt, History of Tennessee and the Tennesseeans. Chicago and New York: Lewis Publishing Company, 1913, Vol. I.

Henige, David. “Brent Kennedy’s Melungeons.” Appalachian Journal 25 (1998): 270286.

Herring, Susan C. "Computer-mediated Discourse." in The Handbook of Discourse Analysis, eds. Deborah Schiffrin, Deborah Tannen, and Heidi E. Hamilton. Malden, MA: Blackwell Publishers, 2001. 
Hirschman, Elizabeth C. Melungeons: the Last Lost Tribe. Macon, GA: Mercer University Press, 2005.

Hodge, Robert and Gunther Kress. Language as Ideology $2^{\text {nd }}$ ed. New York: Routledge, 1993.

Humble, Christopher H. “A Visit to the Melungeons." Home Mission Monthly 11 (1897): 243-46.

Ivey, Saundra Keyes. "Oral, Printed and Popular Culture Traditions Related to the Melungeons of Hancock County, Tennessee.” Ph.D. dissertation,. Indiana University, 1976.

Johnson, Mattie Ruth. My Melungeon Heritage: A Story of Life on Newman's Ridge, Johnson City, TN: Overmountain Press, 1997.

Jones, Kevin. “DNA Study Results.” Presentation at Fourth Union, 20 June 2002, Kingsport, TN.

Judge, Joseph. "Between Columbus and Jamestown: Exploring Our Forgotten Century." National Geographic, March 1988, 330-363.

Kennedy, N. Brent. Letter to the Editor. Appalachian Journal 27, no. 2 (2000): 124. . "A New Path," (http://www.melungeons.com/articles/a statement from brent kennedy.htm) Accessed 22 July 2003.

--------. "Kennedy Announces New Focus in Personal Mission,” Under One Sky: The Melungeon Information Exchange 3:1 (1998) accessed on Darlene Wilson's Melungeon Website, now defunct.

----------. Speech at East Tennessee State University (ETSU), 29 September 1997.

---------. "Statement from Brent Kennedy 12-03-02." The Melungeons (melungeons.com). Website. 2002-2005. Available from http://www.melungeons.com. Internet;. Accessed 25 June 2005.

Kennedy, N. Brent with Robyn Vaughn Kennedy, The Melungeons, The Resurrection of a Proud People: An Untold Story of Ethnic Cleansing in America, Macon, GA: Mercer University Press, 1994.

Killebrew, Libby Pearson. Letter to the Editor. Appalachian Journal 27 (2000): 120-23.

Kress, Gunther. Literacy in the New Media Age. London: Routledge, 2003. 
Leonard, Chester F. “Annual Report.” Vardy Community Presbyterian Church Records, 1934.

---------- "Helping a Community to Help Itself: A Story of Christian Cooperation and Expanding Vision That Follows the Gospel in the Mountains." Presbyterian Advance, 18 October 1928, 10+.

---------. “How We Use Slides.” Church Management, Dec. 1939.

"Vardy Community School." Mountain Life and Work, January 1938: 4-7.

---------. "Meeting of Elders and Deacons of Vardy Community Church." 14 September 1947.

Maggard, Dennis. Melungeon-L List Owner. Email to author. 15 March 2002.

Manovich, Lev. The Language of New Media. Cambridge, MA: MIT Press, 2001.

Melungeon Records. Website. available from http://www.melungeonrecords.com/. Internet. Accessed 16 July 2005.

McCauley, Deborah Vansau. Appalachian Mountain Religion: A History. Urbana: Illinois University Press, 1995.

Minutes of Stony Creek Primitive Baptist Church, Scott County, VA, September 26, 1813. http://ftp.rootsweb.com/pub/usgenweb/va/scott/church/stonycrk.txt Accessed 20 July 2003.

Montessori, Maria. The Montessori Method. 1912; reprint, New York: Schocken Books, 1964.

Morrison, Nancy Sparks. Melungeon Health. Website. 2003-2005. Available from http://www.melungeonhealth.org/info.html. Internet. Accessed 23 July 2003 and 31 July 2005.

Overbay, DruAnna Williams. Windows on the Past. $2^{\text {nd }}$ ed. Macon, GA: Mercer University Press, forthcoming, 11-12.

."Melungeon Web Sites," email to the author, 24 June 2005.

Pezzullo, Joanne. Historical Melungeons. Website. 2002. Available from http://www.geocities.com/ourmelungeons/front.html. Internet. Accessed 20 July 2005.

---------. “The Real Melungeons.” Weblog. Posted 7 June 2005. Available at http://therealmelungeons.blogspot.com/. Internet. Accessed 18 July 2005. 
Podber, Jacob. "Bridging the Digital Divide in rural Appalachia: Internet Usage in the Mountains." Published Proceedings, InSite "Where Parallels Intersect," Informing Science + Information Technology Education International Conference, June 2003. Available at http://www.melungeon.org/index.cgi?BISKIT=2404458932\&CONTEXT=cat\&ca $\underline{\mathrm{t}=10062}$. Internet. Accessed 6 June 2005.

Rauschenbusch, Walter. Christianity and the Social Crisis. 1907. New York: Harper \& Row, 1964.

Sachs, Harvey. “The MIR Membership Categorization Device.” Lecture 6 in Lectures on Conversation ed. Gail Jefferson. Oxford, UK, \& Cambridge, MA: Oxford University Press, 1995, 40-48.

Schrift, Melissa. "Melungeons and the Politics of Heritage" in Southern Heritage on Display: Public Ritual and Ethnic Diversity within Southern Regionalism, ed. Celeste Ray. Tuscaloosa and London: University of Alabama Press, 2003, 106-29.

"Sons and Daughters of the Legend." Audiotape of a National Public Radio documentary compiled by Wayne Winkler, WETS-FM, Johnson City, TN.

Sovine, Melanie L. "The Mysterious Melungeons: A Critique of the Mythical Image." Ph.D. dissertation, University of Kentucky, 1982.

Starnes, Richard. "Melungeons Seek to Restore Heritage that Racism Killed: A Tiny Mixed-race Tribe Is Using the Internet to Lead Its People Back from Obscurity." The Ottawa Citizen, 2 August 1997, A:6.

Stefik, Mark. Introduction to "Some Consequences of Electronic Groups" by Lee Sproull and Samer Faraj, Internet Dreams: Archetypes, Myths, and Metaphors, edited by Mark Stefik. Cambridge, MA: MIT Press, 1996, 125-134.

Stephens, Mitchell. The Rise of the Image, the Fall of the Word. New York: Oxford University Press, 1998.

Street, Brian V. Literacy in Theory and Practice. Cambridge, UK: Cambridge University Press, 1984.

Swales, John. Genre Analysis: English in Academic and Research Settings. Cambridge, UK: 1990.

Swartz, David. Email exchange with Katherine Vande Brake concerning Swartz's Internship at Vardy 1946-47. 18 October - 5 November 2003. 
Turner, Patricia A. I Heard It Through the Grapevine: The Rhetoric of Rumor in Black Culture. The Regents of the University of California, 1993.

Turnmire, Danny. "Education of the Melungeons: From Distinction to Extinction." M.A. Thesis, Union College, Barbourville, KY, 1984.

Vande Brake, Katherine. How They Shine: Melungeon Characters in the Fiction of Appalachia Macon, GA: Mercer University Press, 2001.

Vardy Community Historical Society. Windows on the Past:The Cultural Heritage of Vardy, Hancock County, Tennessee. Sneedville, TN: Vardy Community Historical Society, 2002.

Vardy Presbyterian Church Record Books. 3 vols. Vardy, Tennessee, 1902-1973.

Vaughn, Marshall E. "Purpose of this Magazine.” Mountain Life and Work 1:1 (1925), 23.

Watkins, Gloria (bell hooks). Teaching Community: A Pedagogy of Hope. New York: Routledge, 2003.

Wenger, Etienne, Richard McDermott, and William Snyder. Cultivating Communities of Practice: A Guide to Managing Knowledge. Boston: Harvard Business School Press, 2002.

Whisnant, David E. All That Is Native and Fine. Chapel Hill: University of North Carolina Press, 1983.

Wilkins, Harriet. “Computer Talk: Long-Distance Conversations by Computer.” Written Communication 8 (1991): 56-78.

Williams, Samuel C. Early Travels in the Tennessee Country. Johnson City, TN: The Watauga Press, 1928.

Wilson, Darlene. “A Response to Henige.” Appalachian Journal 25 (1998): 287-88.

---------. “'Black Dutch'-A Polite Euphemism.” Appalachian Quarterly 3 (1998): , revised at http://www.melungeons.org/dw dutch.htm. Accessed 17 August 1999. This website is no longer available.

--------. "Race, Face, and Place: On Becoming Color-Minded," Under One Sky, April 1997. Found at http://www.melungeons.org/mel_uos2.htm . Accessed 22 August 1999. This website is no longer available.

Wilson, Samuel Tyndale. The Southern Mountaineers. New York: Presbyterian Home Missions, 1914. 
Winkler, Wayne. "A Brief Overview of the Melungeons." http://www.melungeons.com/articles/january 2003.htm Accessed 17 July 2003.

--------. Melungeon Heritage Association. Website 2005. Available from http://www.melungeon.org/. Internet. Accessed 23 July 2005.

---------. Walking Toward the Sunset: The Melungeons of Appalachia. Macon, GA: Mercer Univesity Press, 2004.

Worden, William L. "Sons of the Legend." Saturday Evening Post 18 October 1947: 28+. 